UNIVERSIDADE DE SÃO PAULO

FACULDADE DE EDUCAÇÃO

ALESSANDRA FERNANDES BIZERRA

\title{
Atividade de aprendizagem em museus de ciências
}





\section{Atividade de aprendizagem em museus de ciências}

Tese apresentada à Faculdade de Educação da Universidade de São Paulo para a obtenção do título de Doutora em Educação.

Área de Concentração: Ensino de Ciências e Matemática

Orient.: Profa. Dra. Martha Marandino

São Paulo

2009 
Autorizo a reprodução e divulgação total ou parcial deste trabalho, por qualquer meio convencional ou eletrônico, para fins de estudo e pesquisa, desde que citada a fonte.

Catalogação na Publicação

Serviço de Biblioteca e Documentação

Faculdade de Educação da Universidade de São Paulo

Bizerra, Alessandra

Atividade de aprendizagem em museus de ciências /

Alessandra Bizerra; orientação Martha Marandino. São Paulo:

s.n., 2009.

$274 \mathrm{p}$.

Tese (Doutorado - Programa de Pós-Graduação em Educação. Área de Concentração: Ensino de Ciências e Matemática) - Faculdade de Educação da Universidade de São Paulo.

1. Museus - Educação 2. Educação não formal 3.

Aprendizagem 4. Teoria da Atividade 5. Comunidades de Prática 6. Museus de ciência e tecnologia I. Marandino, Martha, orient. 
BIZERRA, A. Atividade de aprendizagem em museus de ciências. Tese apresentada à Faculdade de Educação da Universidade de São Paulo para obtenção do título de Doutora em Educação.

Aprovado em:

\section{Banca Examinadora}

Prof. Dr.

Instituição:

Julgamento:

Assinatura:

Prof. Dr.

Julgamento:

Instituição:

Assinatura:

Prof. Dr.

Instituição:

Julgamento:

Assinatura:

Prof. Dr.

Instituição:

Julgamento:

Assinatura:

Prof. Dr.

Instituição:

Julgamento:

Assinatura: 

Ao Daniel, amor companheiro, amor amigo, amor sem fim... 



\section{AGRADECIMENTOS}

\section{Se eles fossem um museu...}

Tentarei expressar a alegria por poder contar com amigos e colegas que, de diferentes formas, ajudaram-me ao longo de tão intenso caminho. Para isso, vale imaginar um museu de agradecimentos em que os objetos são os mediadores entre essas pessoas queridas e a consideração que tenho por elas.

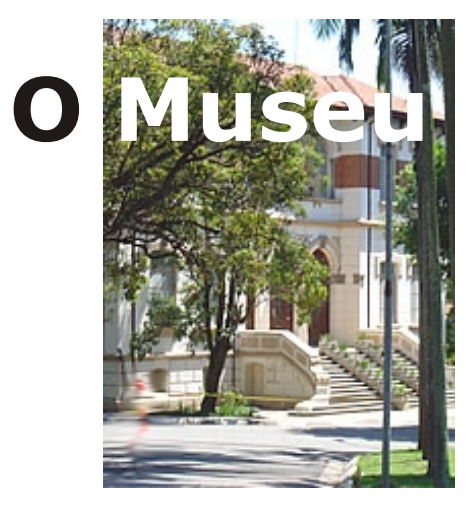

O espaço do museu é amplo, semelhante ao parque do Instituto Butantan, instituição secular, carismática, repleta de bons objetos de estudo. É um local dedicado aos profissionais de museus que buscam fortalecer o papel social dessas instituições e aos frequentadores desses espaços, que promovem a re-produção da cultura.

Em uma de suas edificações, há a exposição de longa duração "Atividade de aprendizagem em museus de ciências".

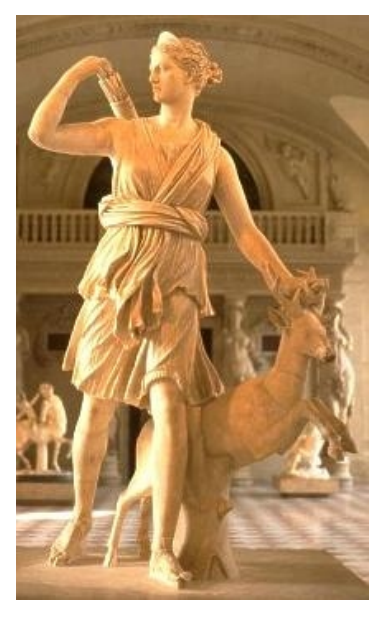

No hall de entrada desta edificação, local de encontro entre amigos, espaço de construção coletiva, encontra-se uma escultura de Diana, mulher deusa guerreira, que com beleza e força transforma o mundo em que vive. Martha, amiga querida e orientadora paciente, poderia ser Marandiana, fácil, fácil... A ela, mil agradecimentos por todo carinho, compreensão e maestria com que conduz suas relações. 

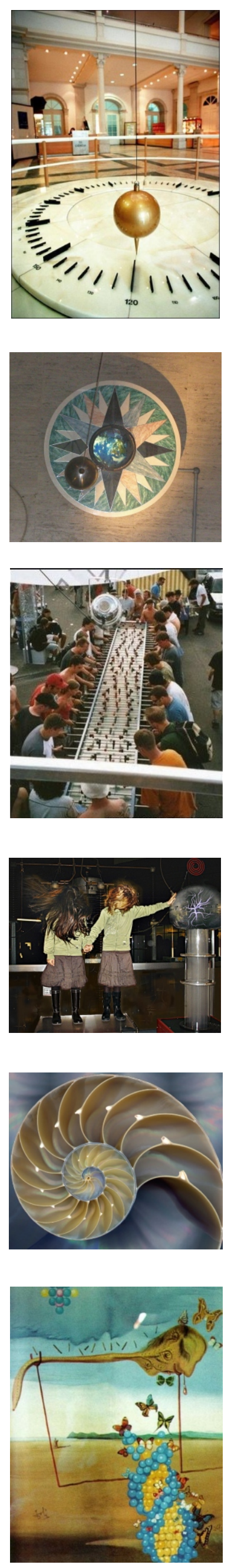

Logo em seguida, há a "Salla ZDP", onde se encontram as referências aos amigos e colegas que me ajudaram a fazer algo que antes não conseguia fazer. As interações com os amigos do GEENF, principalmente os veteranos Adriano, Ana Maria, Djana, Luciana Martins, Judith, Luciana Mônaco, Maria Júlia, Maria Paula, Rodrigo, Viviane e, claro, Martha, ampliaram, em muito, minha zona de desenvolvimento imediato. As teses e dissertações do GEPAPe, assim como as do GEENF, foram para mim "um parceiro mais capaz".

Há ainda nesta sala um pêndulo de Foucault (um aparato que demonstra a rotação da terra em relação a um referencial). Assim como o pêndulo não pode faltar em um museu de ciências, o Prof. Oriosvaldo de Moura não pode estar ausente em um trabalho sobre Teoria da Atividade. Sem ele, os caminhos a serem percorridos em relação a esse referencial tornam-se tortuosos. O mesmo pode ser dito sobre Douglas Falcão em relação à aprendizagem em museus. A ajuda desses dois pesquisadores, principalmente na qualificação, foi valiosa.

Importante também é a "Sala dlo Making Off”, um espaço gigantesco, com numerosos aparatos interativos.

Estão lá, por exemplo, computadores, gravadores, filmadoras, websites, serviços eletrônicos, enfim, aparatos variados que me acompanharam na jornada. Sem a ajuda em como usá-los e em sua disponibilização por Maurício Pietrocola e Renata (LaPEF), Marcelo Giordan e Adriana (LAPEQ), Marcos (Escola de Aplicação), funcionários da Biblioteca e da Pós-graduação, a coleta e a sistematização dos dados seriam ainda mais difíceis.

Não falta nessa sala uma mesa de pebolim, um exemplo de que o trabalho coletivo é ainda mais divertido. Os amigos do Museu Biológico Bruna, Cibele, Cynthia, Danilo, Fabíola, Igor, Isa, Jéssyca, João, Marcelo, Margarida, Murilo, Nésia, Raimunda, Sandra, Schunck, Yoichi, ajudantes de coleta de dados e resolvedores de problemas, foram grandes parceiros de jogo.

Está lá, também, o gerador de Van der Graff, aquela esfera de metal que, assim como a Alessandra Schunck, mesmo deixando todos de cabelo em pé, é imprescindível em um museu de ciências. A ela, agradeço pela companhia, apoio e tentativas de me transformar em uma esportista.

Obras variadas que, de forma bela, ressaltam a unidade ciência e arte, como o faz Antonio Carlos "Totô" O. R. da Costa, encontram-se nessa sala. Agradeço a ele pela ajuda constante. 

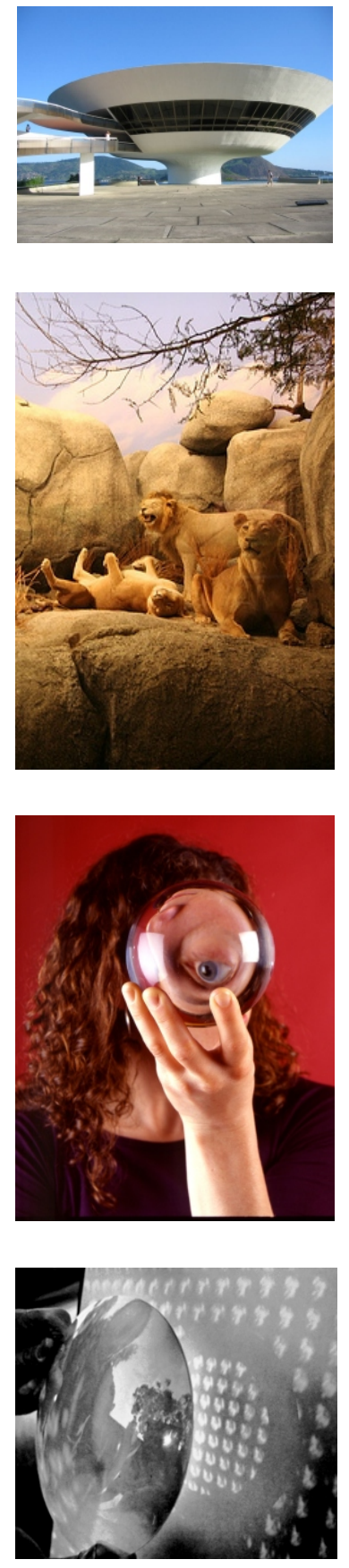

\section{Há ainda a "Sala do Apoio".}

Nela, uma maquete do Museu de Arte Moderna de Niterói, cuja arquitetura é um exemplo da importância de um corpo central de sustentação, é o aparato nuclear. Meus parentes, sem dúvida, foram fundamentais para que esse trabalho frutificasse, principalmente meus pais, Andréa, Luciene, Madalena, Miranda, Sofia e Gustavo que compreenderam a ausência e me apoiaram continuamente. Miguel, com seus poucos anos de vida, mostrouse paciente e cuidadoso (exceto com meus livros). A ele, um rio de agradecimentos por ter enchido minha vida de alegrias.

Outro aparato está em destaque: o diorama do cuidado parental. Nele estão representadas fêmeas que cuidam da prole de outras, como as leoas. Agradeço àqueles, principalmente Andréa e Madá, que cuidaram de meu filhote nos momentos de pânico, recorrentes nesses anos de trabalho.

Jogos de lentes de diferentes formas e tamanhos, que permitem a visão do mundo de um outro jeito, estão presentes para agradecer aos amigos que me ajudaram a olhar para os conflitos encontrados ao longo desse processo sob outras óticas. Rosana, Laís e Beto, Marquinhos e Dri, Sylene, Antonio, as meninas do Horto, as meninas do GEENF, Maurício, Glaucia e Milene contribuíram de diferentes formas para resolvê-los.

À Milene Tino De Franco e ao Maurício Pietrocola, meu agradecimento especial por viabilizarem a concretização desse trabalho. À Sônia Lopes, agradeço pelo importante apoio inicial.

A todos os amigos e colegas do Museu de Microbiologia e outros laboratórios do Instituto Butantan, agradeço o apoio e a compreensão pela ausência em diversos momentos. 
Como em muitos museus, há ainda sua cafeteria. No museu de agradecimentos, chama-se "Café Referência". Esse é um local de conversas e compartilhamento de sentidos e significados atribuídos às coisas do mundo. É o espaço onde são colocadas em diálogo impressões e sensações, onde, no contato, com o outro, aprendo a ser pesquisadora. No Café Referência encontram-se pessoas que me inspiraram na construção do referencial teórico desta pesquisa.

Além dos clássicos Vigotski, Leontiev, Davidov, Jean Lave, Prof. Ori, estão presentes ainda figuras como Milene, Osvaldo, Otavio, Ricardo, Rute e Selma que, entre outros, são membros experientes da comunidade de prática de pesquisadores que atuam de modo ético e salutar.

Lembrando que alguns nexos conceituais importantes devem aparecer ao longo de toda a exposição e em diferentes aproximações, Martha novamente está presente!

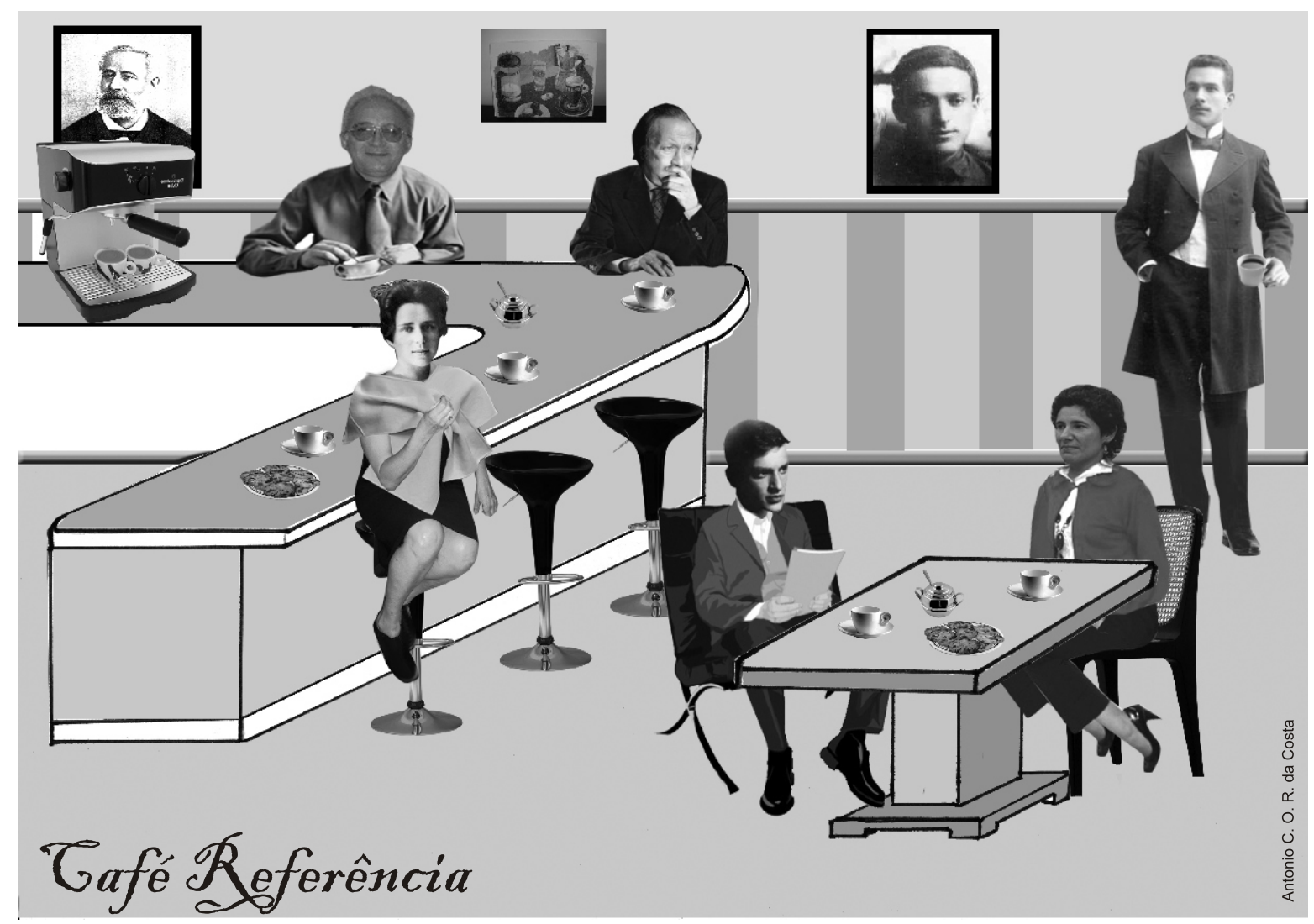

Todo museu tem seu acervo, fonte rica de informações sobre o mundo e promotora de emoções. É o acervo de um museu que fornece opções de mudança, de novas leituras do mundo, de novas sensações a quem com ele interage. Ele é a alma do museu. Ele confere a esta instituição um caráter de expressão da humanidade.

$\mathrm{O}$ acervo do museu de agradecimentos tem um nome bastante especial: 


\section{RESUMO}

BIZERRA, A. Atividade de aprendizagem em museus de ciências. 2009. 274fls. Tese (Doutorado em Educação) - Faculdade de Educação, Universidade de São Paulo, São Paulo, 2009.

Os museus, independentemente de sua tipologia e contexto de origem, mantêm em comum seu caráter de conservação e preservação do patrimônio cultural, bem como sua disponibilidade em ressignificá-lo. Embora historicamente o papel social dessas instituições tenha se alternado em força e motivos, uma dimensão torna-se evidente: os museus, nos modelos conhecidos hoje, apresentam-se como espaços educativos, organizados, com conhecimento humano historicamente construído, compartilhado e reproduzido por sujeitos ativos. Mas como os museus conduzem desse processo, considerando seu público como composto por sujeitos que atribuem valores e significados a esse patrimônio? Buscando uma reflexão sobre o entendimento do papel social dos museus no que tange à apropriação e re-produção da cultura, foi utilizado o referencial histórico-cultural, baseado nas ideias de Vigotski, Leontiev e Davidov e focado o processo de aprendizagem de conceitos e práticas. Com essa escolha, procurou-se compreender como está estruturada uma atividade de aprendizagem, de ressignificação do patrimônio, em museus de ciências. Assumiu-se, a priori, que essas instituições são locais em que o processo de aprendizagem está presente, mas não necessariamente a atividade de aprendizagem. Diferenciou-se, portanto, "aprendizagem" de "atividade de aprendizagem", considerando-se que, a última, deveria ser investigada. Foi escolhida uma instituição para análise, o Museu Biológico do Instituto Butantan, e procurou-se compreender o atual uso de sua exposição de longa duração, por meio de uma perspectiva histórica. Para isso, foram analisados documentos oficiais e acervos institucionais e pessoais relacionados às práticas de educação em ciências e divulgação científica realizadas pelo Instituto Butantan desde sua criação, em 1901. Os macrociclos de atividade de aprendizagem expansiva encontrados permitiram compreender a atual exposição não somente como produto dos anseios e pressupostos da equipe de profissionais envolvidos, mas como fruto de atividades desenvolvidas por todo um século, que influenciam atualmente as interações estabelecidas entre público e instituição. Em um nível maior de escala, foi realizada a análise de ciclos e microciclos de aprendizagem por meio do olhar de visitantes e monitores. Para isso, foram realizadas entrevistas semi-estruturadas, registradas em áudio e vídeo, com mediadores do museu e famílias de visitantes. Os referenciais utilizados nessa investigação, incluindo o conceito de "comunidades de prática", ofereceram dicas importantes de organização da atividade educativa em museus de ciências, especialmente relacionadas ao posicionamento do objeto museal como artefato mediador. Elementos como o uso de modelos germinais e de situações-problema, a seleção de conceitos e práticas nucleares, a promoção da ascensão do abstrato ao concreto, o movimento entre ações e operações, a zona de desenvolvimento imediato como propulsora do desenvolvimento, a mediação semiótica e social apresentaram-se como elementos importantes para a práxis profissional dos educadores de museus. Com as relações estabelecidas entre a Teoria da Atividade e a Aprendizagem em Museus, espera-se que esta investigação tenha contribuído para o entendimento dos museus como estruturas "mediadoras", facilitadoras das múltiplas possibilidades de interação entre o sujeito e a cultura.

Palavras-chave: Museus - Educação, Educação não formal, Aprendizagem, Teoria da Atividade, Comunidades de Prática, Museus de ciência e tecnologia. 


\begin{abstract}
BIZERRA, A. Learning activity in science museums. 2009. 274p. Thesis (PhD in Education) - Education Faculty, São Paulo University, São Paulo, 2009.

The museums have in common the character of cultural heritage conservation and extroversion regardless of their kind and origin context. Although historically the social role of these institutions have been changing in power and reasons, a dimension becomes clear: the museums, the model known today, are educational spaces, organized with human knowledge historically constructed, shared and re-produced by active subjects. How do the museums lead this process, considering their audience as composed of individuals that give values and meanings to this heritage? Intending a discussion on understanding the social role of museums in terms of appropriation and re-production of culture, we used the historical-cultural approach, based on the ideas of Vygotsky, Leontiev and Davydov and we focused on the process of learning concepts and practices. With this choice, we aimed to understand how the learning activity is structured in science museums. We have assumed a priori that these institutions are places where the learning process is present but not necessarily the activity of learning. We distinguished, therefore, "learning" from "learning activity", considering that the latter should be investigated. An institution was chosen for analysis, the Biological Museum of Butantan Institute, and we tried to understand its long-term exhibition through a historical perspective. For this, we analyzed documents and institutional and personal collections related to science education and science communiation practices held by the Butantan Institute since its creation (1901). The macrocycles of expansive learning founded helped us to understand the current exhibition not only as a product of the anxieties and assumptions of the team of professionals involved, but as a result of activities developed in a whole century, which currently affect the interactions between audience and institution. On a higher level of scale, the analysis of cycles and microcycles of learning activity was developed by the point of view of visitors and monitors. For that, semi-structured interviews with museum explainers and visitor families were recorded on audio and video. The theoretical approaches used in this research, including the concept of "communities of practice", offered important tips for organizing the educational activities in science museums, especially related to the positioning of the museum object as mediator artifact. Elements such as the use of germ-cell models and inquiry situations, the selection of nuclear concepts and practices, the promoting of the ascending from abstract to concrete, the movement between actions and operations, the use of the proximal development zone, the social and semiotic mediation, were described as important for the professional praxis of museum educators. With the relationship between activity theory and learning in museums, it is expected that this research may contribute to the understanding of museums as "mediators" structures which facilitate the many possibilities of interaction between the individuals and culture.
\end{abstract}

Keywords: museum education; informal education, learning, activity theory, communities of practice, science museum 


\section{LISTA DE FIGURAS}

Figura 1 - Níveis hierárquicos da atividade (LEONTIEV, 2004) ............................ 69

Figura 2 - Modelo de um sistema de atividade (ENGESTRÖM, 1999a).................... 70

Figura 3 - Ciclos expansivos, com processos de internalização e externalização (ENGESTRÖM, 1999a)

Figura 4 - Quadro com ferramentas de análise de eixos discursivos segundo Nascimento (2007)

Figura 5 - Sala de exposição brasileira na Exposição Internacional de Higiene, em Dresden (Alemanha), em 1911 (Acervo: Casa de Oswaldo Cruz)...... 100

Figura 6 - Material de divulgação do fármaco comercial Específico Pessoa utilizado popularmente para o tratamento de acidentes ofídicos (Acervo Pessoal de Henrique Moises Canter).....

Figura 7 - Ciclos de aprendizagem expansiva observados ao longo do século XX na área educativa do Instituto Butantan, formado por microciclos de diferentes escalas.

Figura 8 - Exposição do Museu no prédio Lemos Monteiro, em 1939 (Acervo Iconográfico do Instituto Butantan).

Figura 9 - Exposição do Museu Provisório, em 1957 (Acervo Iconográfico do Instituto Butantan)....

Figura 10 - Reforma da antiga cocheira que passou a abrigar o Museu do Instituto Butantan desde 1966, em 1972 (Acervo Iconográfico do Instituto Butantan).

Figura 11 - Biodiorama de boiubu, na exposição de longa duração do Museu Biológico do Instituto Butantan (Foto: Alessandra Schunck).

Figura 12 - Dioramas de jararaca-ilhoa (a) e de jararaca-de-alcatraz (b), na exposição temporária Serpentes das Ilhas de São Paulo (Fotos: Antonio Carlos O. R. da Costa).

Figura 13 - Croqui do espaço expositivo do Museu Biológico do Instituto Butantan (Fonte: folder de divulgação do Museu - Divisão de Desenvolvimento Cultural/IBu).

Figura 14 - Legenda do biodiorama de jararaca a) completa e b) em detalhe (Foto:

Alessandra Schunck). 
Figura 15 - Sistemas de mediação observados na iniciação de Sofia à leitura de ícones.

Figura 16 - Ciclo de aprendizagem expansiva segundo Engeström (1999b)........... 168

Figura 17 - Sistemas de interações apresentadas pelas famílias G6 e G7 175

Figura 18 - Modelo de atividade de ensino/aprendizagem de visitantes do Museu Biológico. 178

Figura 19 - Modelo de atividade de ensino/aprendizagem de Antônia 182

Figura 20 - Estrutura triádica do signo em Peirce (retirado de PINO, 2005) 185

Figura 21 - Modelo germinal representativo da relação variação geográfica polimorfia em três estágios de particularização.

Figura 22 - Modelo para a atividade de ensino/aprendizagem em um museu de ciências. 


\section{LISTA DE TABELAS}

Tabela 1 - Trabalhos sobre aprendizagem em museus selecionados para análise e organizados em categorias segundo o tipo de publicação.

Tabela 2 - Características principais dos conhecimentos teórico e empírico extraídas de Rubtsov (1996).....

Tabela 3 - Número de artigos publicados no periódico "Memórias do Instituto Butantan", entre os anos de 1918 e 1969, separados por temas. Fonte: Remissive List of Papers Published in "Memórias do Instituto Butantan"volumes 1 to 33 (1918-1966). Mem. Inst. But., 34:209-249, 1969....

Tabela 4 - Número de artigos publicados no periódico "Memórias do Instituto Butantan", entre os anos de 1970 e 1989, separados por temas. Fonte: Lista Remissiva dos Trabalhos Publicados nas "Memórias do Instituto Butantan"- volumes 34 a 38 (1969-1974). Mem. Inst. But., 39:239-245, 1975; volumes 39 a 46 (1975-1982), Mem. Inst. But., 47:205-216, 1983 e volumes 47 a 51 (1983-1989), Mem. Inst. But., 52:107-111, 1990.

Tabela 5 - Aparatos da exposição de longa duração do Museu Biológico do Instituto Butantan

Tabela 6 - Aparatos da exposição temporária "Serpentes das Ilhas de São Paulo" do Museu Biológico (IBu).

Tabela 7 - Ações de aprendizagem segundo Davydov (1988b) e Engeström (1999b)....... 173

Tabela 8 - Atividades de monitoria de Antônia e Micael. 


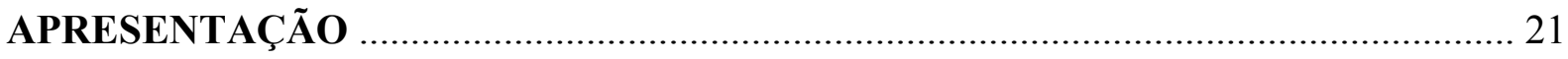

1 MUSEUS DE CIÊNCIAS COMO ESPAÇOS DE APRENDIZAGEM ...................... 31

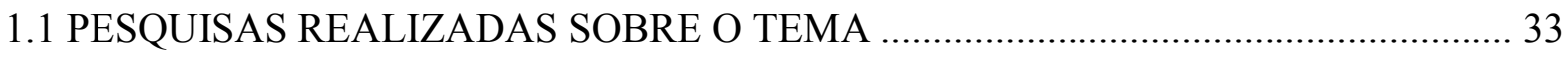

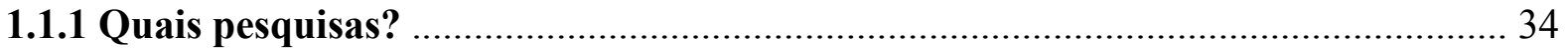

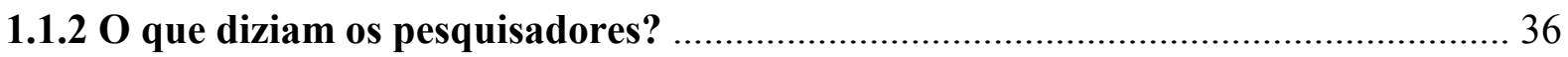

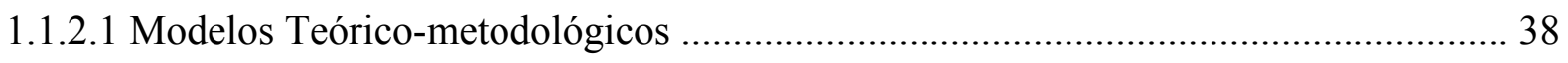

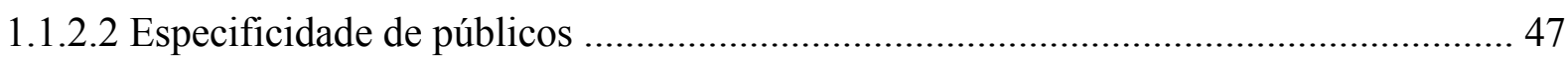

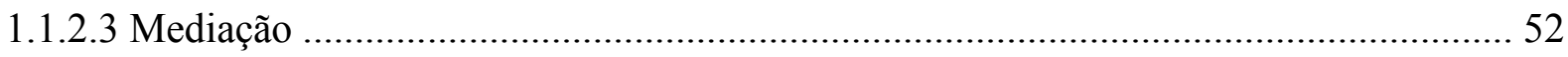

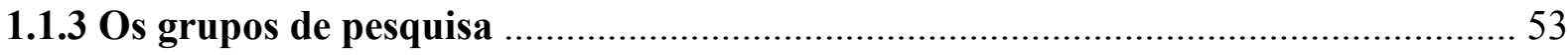

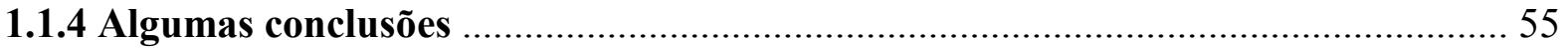

1.2 O MUSEU DE CIÊNCIAS COMO ESPAÇO DE APRENDIZAGEM .......................... 58

2 TEORIA DA ATIVIDADE E ATIVIDADE DE APRENDIZAGEM ......................... 61

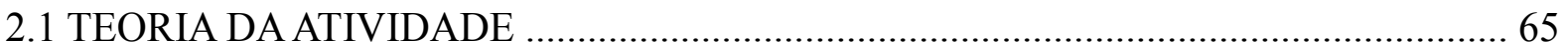

2.2 TEORIA DA ATIVIDADE, ATIVIDADE DE APRENDIZAGEM E ATIVIDADE DE

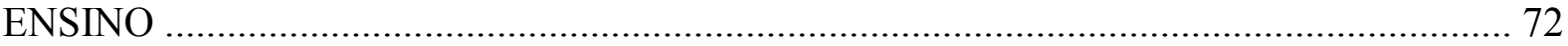

2.3 ATIVIDADE DE APRENDIZAGEM E MUSEUS DE CIÊNCIAS ............................... 85

3 A ORIGEM E O DESENVOLVIMENTO DA ATIVIDADE DE ENSINO/APRENDIZAGEM NO INSTITUTO BUTANTAN ................................... 91

3.1 A DIVULGAÇÃO CIENTÍFICA E A EDUCAÇÃO EM CIÊNCIAS NO MUNDO ..... 94

3.1.1 O euforismo científico no Brasil: particularidades e modismos .............................. 96

3.2 OS SISTEMAS DE ATIVIDADE DE ENSINO/APRENDIZAGEM NO INSTITUTO

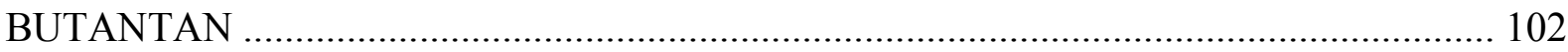

3.2.1 A diversificação nas estratégias de divulgação científica e educação em saúde do Instituto Butantan 
4 CICLOS E MICROCICLOS DE ATIVIDADE DE ENSINO/APRENDIZAGEM EM MUSEUS DE CIÊNCIAS

4.1 A COLETA DE DADOS - VISITANTES E PROFISSINAIS DE MUSEU................. 135

4.1.1 A exposição de longa duração do Museu Biológico ............................................. 138

4.2 A ATIVIDADE DE ENSINO/APRENDIZAGEM PELO OLHAR DO VISITANTE . 144

4.2.1 Mediação semiótica e mediação social ................................................................. 149

4.2.2. A formação conceitual e a ascensão do abstrato ao concreto ............................. 161

4.3 A ATIVIDADE DE ENSINO/APRENDIZAGEM PELO OLHAR DO MONITOR .... 178

4.4 A ATIVIDADE DE VISITA ENQUANTO ATIVIDADE DE APRENDIZAGEM ..... 182

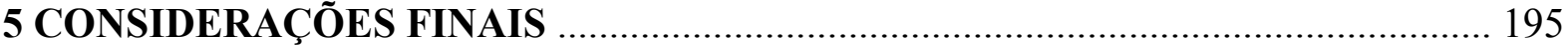

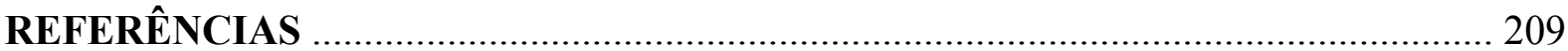

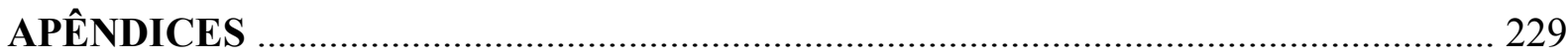

1 OUTRAS ESTRATÉGIAS EDUCACIONAIS E COMUNICACIONAIS

DESENVOLVIDAS PELO INSTITUTO BUTANTAN DURANTE

O SÉCULO XX

2 ROTEIRO DE ENTREVISTAS

3 EQUIPAMENTOS UTILIZADOS PARA A COLETA DE DADOS

JUNTO ÀS FAMÍLIAS.

ANEXOS

1 LISTA DE TRABALHOS ANALISADOS 

Apresentação 



\section{APRESENTAÇÃO}

"não basta olhar para as coisas e para a vida; é preciso sentir e pensar sobre elas para conhecê-las".

Lanner de Moura

Os museus são instituições historicamente reconhecidas por sua intencionalidade em olhar a realidade e concretizá-la, dialeticamente, em objetos tangíveis ou intangíveis. Em outras palavras, possuem a atividade de musealizar o mundo em que vivemos, por meio da conservação do patrimônio cultural e de sua ressignificação. É claro que a heterogeneidade de discursos relacionados a essas instituições constitui-se em uma rede complexa e dinâmica de entendimentos reconstruídos continuamente por indivíduos que refletem sobre elas e se engajam na sua reestruturação. Esses discursos e o modo como são analisados dependem do ponto de partida, do local de fala de seus enunciadores. Governantes, pesquisadores, visitantes, não-visitantes, profissionais ligados aos museus, entre outros sujeitos, disponibilizam numerosas abordagens, divergentes ou convergentes entre ou dentro desses diferentes grupos.

Apesar da variada possibilidade de reflexão sobre o fenômeno museal, uma delas perpassa as demais: o papel social dessas instituições. Os museus, independentemente de sua tipologia e contexto de origem, mantêm em comum seu caráter de conservação e preservação do patrimônio cultural, bem como sua disponibilidade em ressignificá-lo.

Embora historicamente o papel social dos museus tenha se alternado em força e motivos $^{1}$, uma dimensão torna-se evidente: os museus, no modelo que conhecemos hoje, sempre se apresentaram como espaços educativos, organizados, com conhecimento humano historicamente construído, compartilhado e re-produzido por sujeitos ativos. Como coloca Hooper-Greenhill (1999a, p. 3), pesquisadora inglesa interessada na interpretação do patrimônio cultural, os museus possuem as mais variadas formas organizacionais, que podem ser adaptadas às mais variadas especificidades locais, mas, para todos eles, "o seu papel educacional é crucial".

Entretanto, como coloca Anico (2005), frente ao quadro de intensificação dos fluxos culturais globais, a esse mundo de simulações e simulacros (Baudrillard, 1991) baseado, por vezes, na instantaneidade e na superficialidade (haja vista algumas das exposições atuais Para um detalhamento dos diferentes caminhos tomados pelos museus e uma reflexões sobre o pensamento
museológico contemporâneo, sugerimos a leitura de Araújo; Bruno (1995) e Martins (2006). 
produzidas e consumidas globalmente), como os museus pensam, por meio do patrimônio, a crescente alienação dos sujeitos em relação às suas origens, à sua história, às suas especificidades culturais? Aliada a isso, como a ideia de que o patrimônio musealizado não é neutro, mas sim complexo e sujeito a mudanças de interpretação, faz com que os museus repensem suas práticas educativas?

Esse problema torna-se ainda mais evidente quando pensamos nos museus de ciências, principalmente nos museus de ciências e tecnologia e nos science centers ${ }^{2}$, locais que favorecem a exposição da chamada ciência universal e não raramente apresentam-se com objetivos, expografias e referenciais semelhantes, independentemente de seu local de inserção - seja ele no Brasil, na Malásia ou nos Estados Unidos. Como os museus de ciências podem tornar os indivíduos a eles relacionados partícipes da construção do conhecimento humano ali re-produzido?

Um dos pontos cruciais para um aprofundamento nesta questão é o fato de que o papel educativo do museu é visto, comumente, como restrito ao processo de extroversão do patrimônio e não imersos na cadeia operatória de procedimentos técnico-científicos (cf. BRUNO, 2002) presentes nessas instituições. Embora a visão restritiva de uma educação em museus a serviço da tradução do patrimônio aos grupos escolares e turísticos já não seja preponderante entre os profissionais de museus, ainda persiste a compreensão de um setor educativo voltado especificamente à extroversão de seu acervo.

Tradicionalmente, o papel educativo dos museus é atrelado a esse elo da cadeia operatória. A grande maioria das práticas educacionais ainda hoje consideradas como tal (assim como suas controvérsias) foi pioneiramente introduzida pelos staffs dos museus há mais de um século. Como aponta Hein (1998), legendas didáticas (de diferentes formas e tamanhos), palestras e eventos afins, cursos e programas especiais para o público escolar, exibições deliberadamente didáticas e outros programas internos e externos para públicos em geral ou específicos são práticas antigas bastante conhecidas nos museus que permanecem como ações prioritárias de seus setores educativos (ou interpretativos) nos dias atuais.

Essa limitação do caráter educacional à comunicação do patrimônio traz um efeito imediato: a constituição de acervos torna-se representativa de um grupo restrito de indivíduos, com suas próprias intervenções ideológicas. Por conseguinte, traz também um efeito

\footnotetext{
2 Os museus de ciências apresentam-se em estruturas e propósitos variados e, para uma análise sobre seus tipos
} e suas gerações, sugerimos a leitura de McManus (1992) e Cazelli; Marandino; Studart (2003). 
mediato: um processo de alienação de sujeitos, não-partícipes do processo de construção do patrimônio musealizado.

Nesse contexto, para Chapin e Klein (1992), os museus têm muito eficazmente ensinado valores repressivos e distorcidos, enfatizando e exigindo comportamentos de locais sagrados e ajudando a difundir mitos sociais. Os autores consideram os museus como criadores de filtros de observação, de olhares, construídos por uma "cultura dominante", sugerindo que "deveriam parar de ajudar a manter a ordem das coisas e começar a ensinar de modo diferente" (CHAPIN; KLEIN, 1992, p. 60, tradução nossa). Desmantelam a visão de neutralidade dos museus (e de seus acervos) e ressaltam a postura colocada pela Nova Museologia: como os museus podem participar do processo de constituição e ressignificação do patrimônio, considerando seu público como composto por sujeitos ativos nesses processos, que atribuem valores e significados a esse patrimônio?

Nesse sentido, o entendimento do caráter educativo como presente em todos os elementos constitutivos da cadeia operatória museal (que envolve, resumidamente, além da extroversão já citada, o planejamento organizacional e físico, a conservação de objetos, a documentação de informações e a avaliação processual), constitui-se como base para o desenvolvimento de atividades que apresentem um olhar diferenciado para a relação entre a sociedade e os artefatos mediadores da cultura.

Pesquisas que considerem a inserção do olhar educativo em diferentes aspectos, incluindo a seleção, a conservação, a extroversão dos acervos, podem se constituir como pontos importantes de partida. Mas como considerar, com a devida profundidade, tantos parâmetros presentes na cadeia operatória museal? Se um recorte da realidade é necessário frente à vastidão do problema, qual unidade de análise (Vigotski, 2001) ${ }^{3}$ poderia ser utilizada para que a compreensão do todo fosse mantida e, ao mesmo tempo, o entendimento do sujeito como partícipe desses processos fosse considerado?

Essas questões estão distantes de serem respondidas, mas foram mantidas em movimento ao longo desta investigação. Vemos os museus como locais construídos historicamente, como espaços fundamentais de ressignificação de patrimônios tangíveis e intangíveis, continuamente em construção. $\mathrm{O}$ homem atua sobre o ambiente natural e nessa atuação elabora e utiliza instrumentos. Esses instrumentos carregam, portanto, a historicidade da atividade do homem sobre o mundo. Os museus são instituições repletas de história

3 A grafia do nome de alguns dos autores referenciados neste trabalho é apresentada de formas diferentes, dependendo da obra consultada e do idioma original. Foram, por opção, mantidas as formas encontradas em cada obra citada. 
humana, materializada em objetos. São, portanto, educativos, pois trazem em si a possibilidade de re-produção do conhecimento humano na interação do sujeito com elementos da cultura, por meio do objeto museal, um instrumento mediador. Sendo educativa, pressupomos que ocorra o processo de aprendizado ${ }^{4}$.

É necessário enfatizar que as ideias aqui propostas partem do campo do Ensino de Ciências, mais precisamente, da Educação em Museus, sob o olhar de profissionais formados no campo da Biologia e que buscam a articulação com diferentes áreas do conhecimento, no caso a perspectiva histórico-cultural da formação do ser humano entrelaçada à Educação.

Com graduação em Ciências Biológicas, minha formação profissional inicial deu-se em Zoologia e Ecologia, produto das minhas necessidades construídas não somente naquela fase da vida mas provavelmente um dos resultados do grande contato que tive com o "mundo natural", ao participar das aventureiras viagens organizadas por meus pais e ao morar no Amazonas. Priorizei estudos sobre répteis, principalmente cobras e lagartos, seres fascinantes, que povoaram meu imaginário infantil. Frutos dessa fase são a minha dissertação de mestrado ("História Natural de Tomodon dorsatus, Serpentes: Colubridae), além de muitas viagens e histórias. Paralelamente ao trabalho acadêmico, desenvolvi atividades de ensino em ambientes formais e não-formais de educação. Fui professora das redes pública e privada, do ensino fundamental, médio e superior, lecionando Ciências, Biologia e Educação Ambiental. Trabalhei no segundo e terceiro setores, como coordenadora da área pedagógica de uma agência de turismo educacional e como educadora ambiental de uma organização nãogovernamental. Essa gama de atividades e ações, tanto em pesquisa como em ensino, foram fundamentais para que eu pudesse traçar os elementos que me motivam a realizar uma atividade profissional: a pesquisa científica e o trabalho em conjunto com o público.

Entretanto, a definição da área em que eu gostaria de atuar veio com a visita a um museu de história natural. O encantamento de sua construção, os grandes mamíferos taxidermizados expostos ao alcance do público, a variedade de formas de seres vivos, um celacanto, aquela rede de caminhos que poderiam ser trilhados conforme a minha vontade são momentos de uma experiência até hoje relembrada. Foi ali que tive a concretização mental da

\footnotetext{
O termo aprendizado (e não aprendizagem) é aqui entendido como exposto por Oliveira (2006, p. 57), que considera o termo russo "obutchênie" como passível de tradução para "algo como 'processo de ensinoaprendizagem', incluindo sempre aquele que aprende, aquele que ensina e a relação entre essas pessoas". Vale lembrar, entretanto, que no "Prólogo do Tradutor" do livro de Vigotski "A Construção do Pensamento e da Linguagem", de 2001, Paulo Bezerra, ao traduzir a obra diretamente da edição original russa, ressalta que o autor usava o termo ora para designar aprendizagem, ora ensino. Como, para o tradutor, Vigotski criou uma teoria da educação mais como psicólogo do que pedagogo, optou por traduzir o termo "obutchênie" quase sempre como aprendizagem.
} 
importância educativa dessas instituições, seja na conservação do patrimônio ou em sua extroversão ao público. A partir desse momento, passei a participar de cursos, congressos, seminários e reuniões sobre Museologia e, mais precisamente, sobre Educação em Museus. Procurei então uma aproximação da área de pesquisa em Divulgação Científica e Educação em Ciências, sendo que um dos pontos mais importantes para isso foi a minha inserção no GEENF - Grupo de Estudos em Educação Não-Formal e Divulgação Científica, coordenado pela Prof. Dra. Martha Marandino, da Faculdade de Educação da Universidade de São Paulo.

Além disso, a minha atuação profissional, como pesquisadora científica do Museu Biológico do Instituto Butantan e, atualmente, do Museu de Microbiologia do mesmo Instituto, vem recheando de novas necessidades e novos motivos a minha atividade de pesquisa. Nesse instituto, participo, desde 2004, de comunidades de educadores e divulgadores (de diferentes laboratórios e com diferentes visões sobre a ciência) interessados em compreender os processos de divulgação científica e educação em ciências desenvolvidos pela instituição.

Com um interesse crescente em refletir sobre a nossa atuação, estruturamos um grupo de estudo e produção que teve uma relativa importância na organização das atuais atividades educativas e comunicacionais desenvolvidas pelo Instituto Butantan. Com o fortalecimento desse grupo, vem tornando-se viável a implantação de uma linha de pesquisa em Educação e Divulgação Científica em Museus de Ciências, que busca compreender as relações estabelecidas entre a Instituição e os seus diferentes públicos.

A pesquisa aqui apresentada é um dos frutos dessa empreitada, construída em parceria com diferentes sujeitos. No nosso cotidiano dos museus do Instituto, desenvolvemos várias ações constituintes de atividades motivadas por uma necessidade: estabelecer um vínculo comunicacional e educacional com as milhares de pessoas interessadas de diferentes formas pelo Butantan. Uma tarde de domingo agradável com os parentes, um projeto de mestrado, a admiração (ou mesmo o medo) por animais venenosos, a compra de vacinas, são apenas alguns dos motivos que levam as pessoas a visitarem o Instituto Butantan. Mas como se dá essa visita aos museus? Quais são as negociações estabelecidas entre o público e as exposições desses locais? Entre as negociações observáveis, o processo de ensinoaprendizagem faz-se presente de que maneira?

Interessada em aprofundar as reflexões sobre as práticas estabelecidas, busquei analisar a atividade de visita ao Museu Biológico, pois, mesmo sendo a exposição desse museu um dos pontos mais atrativos da Instituição (com um público anual de 
aproximadamente 180.000 visitantes), pouco sabemos sobre os mecanismos utilizados por esse público para se apropriar do discurso exposto. O pouco que sabemos refere-se ao público escolar, que representa a metade do público total. Assim, priorizamos focar o público em geral, não escolar, constituído em grande parte por grupos familiares. Junto com minha orientadora, optamos pela Teoria da Atividade como o referencial teórico que nos ajudaria a compreender o sistema de atividade de visita como um todo. Poderíamos olhar, ao mesmo tempo, para a construção do discurso expositivo pela equipe do museu e para o público que freqüenta esse espaço, bem como para o contexto de regras, motivações, valores, conhecimentos em que a atividade de ensino/aprendizagem está imersa e esteve imersa em sua construção histórica. Com essa dimensão de análise, as questões iniciais, que buscavam compreender de que maneira o processo de aprendizado se dava em museus de ciências, fortaleceram-se nas seguintes questões de pesquisa: assumindo que a aprendizagem é inerente aos espaços museais, podemos afirmar que a atividade de aprendizagem também o é? Em caso afirmativo, como estaria estruturada uma atividade de aprendizagem em museus de ciências?

Assim, a apresentação dessa investigação foi organizada em cinco capítulos. No primeiro, intitulado "Museus de Ciências como espaços de aprendizagem", procuramos entender como está organizada a pesquisa científica sobre aprendizagem em museus de ciências. A partir de um levantamento de pesquisas publicadas por meio de artigos científicos em periódicos (nacionais e internacionais), de livros ou capítulos de livros e de dissertações e teses brasileiras, construímos um retrato aproximativo do atual campo de pesquisa em aprendizagem em museus de ciências, importante para situarmos o referencial teórico escolhido para esta pesquisa entre as investigações em curso na comunidade de pesquisadores da área. Trouxemos uma análise sobre essas pesquisas e algumas considerações sobre as diferentes concepções de aprendizagem presentes nesses espaços. Definimos o que consideramos aqui um espaço de aprendizagem e buscamos entender se os museus podem ser considerados espaços onde ocorre atividade de aprendizagem.

O entendimento dessa diferenciação (aprendizagem - atividade de aprendizagem) exige a apresentação do referencial teórico utilizado, o que é feito no segundo capítulo, "Teoria da Atividade e Atividade de Aprendizagem". Nesse ponto, apresentamos um breve histórico da Teoria da Atividade, sua estruturação e seus componentes, dando um destaque à formação do conceito de atividade. Em seguida, trouxemos as propostas da Teoria da Atividade relacionadas ao campo da aprendizagem, com o conceito de Atividade de 
Aprendizagem e Atividade de Ensino. Procuramos ainda explicitar como essas escolhas definiram as ferramentas metodológicas utilizadas.

A seguir, no terceiro capítulo, "A origem e o desenvolvimento da atividade de ensino/aprendizagem no Instituto Butantan”, aproximamos, em menor escala, o nosso estudo de caso, o museu escolhido para análise. Procuramos compreender a atual exposição de longa duração do Museu Biológico, por meio de uma perspectiva histórica e de integração com outras ações de conservação e extroversão do patrimônio cultural do Instituto. Para isso, foram analisados documentos oficiais e acervos institucionais e pessoais relacionados às práticas de educação em ciências e divulgação científica realizadas pelo Instituto Butantan desde sua criação, em 1901. Foram então traçados os principais macrociclos de atividade de aprendizagem expansiva apresentados pelo Instituto Butantan ao longo do século XX. A dimensão alcançada por essa análise permitiu-nos compreender a atual exposição não somente como produto dos anseios e pressupostos da equipe de profissionais envolvidos, mas também como imersa em um caldo de forças, acordos, valores e crenças, internos e externos ao Instituto, construído durante todo um século, que influencia atualmente as interações estabelecidas entre público e instituição.

No quarto capítulo, tendo em mente o processo histórico da construção da atual exposição de longa duração do Museu Biológico do Instituto Butantan, apresentamos, agora em maior escala, os dados coletados junto a famílias visitantes e monitores do museu e discutimos sobre a possibilidade de uma atividade de aprendizagem em museus de ciências, bem como formas de otimizá-la.

No capítulo final, trazemos algumas reflexões sobre as relações entre a Teoria da Atividade e a Aprendizagem em Museus, esperando que, com elas, possamos contribuir para o entendimento dos museus como estruturas "mediadoras", facilitadoras das múltiplas possibilidades de interação entre o sujeito e a cultura. Esperamos, com isso, ajudar na compreensão de como transformar o óbvio entusiasmo do visitante de museus em ações conectadas, engajadas, integradas que o permitam não somente olhar, mas pensar e sentir sobre aquilo que vê. 

Capítulo 1

Museus de Ciências como espaços de aprendizagem 



\section{MUSEUS DE CIÊNCIAS COMO ESPAÇOS DE APRENDIZAGEM}

A aprendizagem em museus será apresentada nesse capítulo com dois objetivos, importantes para a compreensão do objeto dessa pesquisa - o entendimento da visita aos museus como uma atividade de aprendizagem. O primeiro deles refere-se a uma aproximação ao campo de pesquisa sobre aprendizagem em museus, a fim de localizar o referencial histórico-cultural e, mais precisamente a Teoria da Atividade, entre a miríade de possibilidades colocadas. O segundo relaciona-se ao posicionamento das autoras desta investigação em relação ao tema, ação fundamental para as posteriores reflexões.

\subsection{PESQUISAS REALIZADAS SOBRE O TEMA}

A pesquisa em educação voltada para os museus de ciências tem crescido acentuadamente nos últimos anos, apresentando uma diversidade de abordagens teóricas e metodológicas, de objetos de estudo e de resultados. A função educativa do museu, a relação sujeito-objeto, a mediação, a profissionalização do setor de interpretação, a construção do discurso pedagógico a partir do acervo, as relações museu/escola são alguns dos temas abordados com freqüência. Entre essas múltiplas possibilidades temáticas, a aprendizagem aparece como um dos principais eixos da pesquisa educacional nesses espaços, revelando-se como um importante elemento da ação educativa dessas instituições.

Mas como a aprendizagem é compreendida pelos pesquisadores? Quais os principais modelos teóricos (importados ou construídos na área) que dão suporte a essas pesquisas? Quais os principais elementos abordados nas investigações sobre aprendizagem em museus? Quais as novas possibilidades de pesquisa sugeridas? Que grupos de pesquisa têm tido maior influência na área? Para compreender melhor como está estruturada a pesquisa em aprendizagem em museus, foram selecionados artigos, capítulos de livros, dissertações e teses relacionados ao tema, em diferentes bancos de dados. Os trabalhos levantados foram organizados em categorias temáticas, focadas em questões norteadoras. A partir disso, foram sugeridos alguns temas para futuras pesquisas sobre aprendizagem em museus. 


\subsubsection{Quais pesquisas?}

Para um entendimento do campo de pesquisa sobre aprendizagem em museus de ciências, foram utilizados diferentes bancos de dados, que incluem tanto dados disponíveis on-line, quanto materiais impressos. Os dados virtuais foram obtidos a partir do SibiNet ${ }^{5}$, que sintetiza informações provenientes de diferentes bancos, como o SciElo e o JStor. Foram escolhidos 10 periódicos científicos internacionais ${ }^{6}$ e cinco nacionais ${ }^{7}$ comumente citados na área e que especificam, em seus editoriais, a pesquisa em aprendizagem e/ou em museus, para uma análise detalhada. Em cada uma das revistas, foram procurados os artigos relacionados aos descritores "learning” e “museum". Entre os artigos encontrados, foram selecionados aqueles que, após a leitura do abstract e/ou do texto completo, mostraram a aprendizagem como tema central da pesquisa ou como um dos elementos analisados.

Utilizando-se o banco de dados Dedalus (Biblioteca Virtual da Universidade de São Paulo), o Sistema Nou-Rau (Biblioteca Digital da Unicamp) e o banco de dados da Coordenação de Aperfeiçoamento de Pessoal de Nível Superior (Capes), do Ministério da Educação $^{8}$, foram levantados também livros, dissertações e teses do cenário nacional que apresentavam como palavras-chave os termos "aprendizagem", "museu", "educação não formal" e/ou "educação informal". Foram ainda utilizados trabalhos selecionados pelo critério "aprendizagem como tema central ou como um dos elementos analisados", a partir do banco de dados de materiais impressos do Grupo de Estudos em Educação Não-Formal e Divulgação em Ciências (GEENF), da Faculdade de Educação da Universidade de São Paulo, coordenado pela Profa. Dra. Martha Marandino. Esse banco de dados conta com livros, artigos de periódicos, dissertações, teses, anais de congressos e materiais didáticos sobre Educação Não-Formal.

A partir dos materiais encontrados, foram detectados os principais grupos de pesquisa na área. As listas de publicações citadas por esses grupos em seus websites também foram analisadas.

\footnotetext{
${ }^{5}$ www.usp.br/sibi.

${ }^{6}$ Alambique - Didáctica de las Ciencias Experimentales; Curator; Enseñanza de las Ciencias; Interciência; International Journal of Science Education; Journal of Education in Museums; Journal of Research in Science Teaching; Museum International; Museum Management and Curatorship; Science Education.

${ }^{7}$ Ciência \& Educação; Educação e Pesquisa; Ensaio-Pesquisa em Educação em Ciências; História, Ciências, Saúde - Manguinhos; Revista Brasileira de Educação.

8 www.usp.br/sibi e www.periodicos.capes.gov.br.
} 
Os trabalhos selecionados foram então agrupados em categorias temáticas, considerando-se os principais elementos relacionados ao tema pesquisado:

1) Modelos Teóricos e Metodológicos: nessa categoria, a aprendizagem aparece como objeto de investigação, seja no intuito de definição do termo ou de caracterização dos elementos relacionados ao processo estabelecido no ambiente museal. Os trabalhos que apresentam reflexões sobre referenciais teóricos ou metodológicos utilizados nas pesquisas sobre aprendizagem em museus foram colocados nesta categoria. Foram incluídas ainda as pesquisas que buscam a diferenciação entre os diversos contextos de aprendizagem. Aparecem aqui, os artigos relacionados à caracterização da aprendizagem em diferentes espaços educacionais.

2) Especificidade de públicos: foram incluídas nessa categoria as publicações que abordam a aprendizagem a partir do ponto de vista do visitante. Estudos que procuram compreender os elementos envolvidos no processo de aprendizagem de famílias e grupos escolares entram nessa categoria. Além deles, os estudos de públicos, quando tratam da interpretação da exposição pelo visitante, foram considerados. Ainda, foram incluídas pesquisas que envolvem questões sobre características de públicos, como motivação, conhecimento prévio ou engajamento.

3) Mediação: nessas pesquisas, há uma maior preocupação com questões relacionadas aos mecanismos de interação com os museus de ciências, não diferenciando-os em relação ao público. O foco é no design e nos objetivos das ações educativas dos museus e como essas características estão relacionadas com o processo de aprendizagem. A interatividade física foi incluída nesta categoria, bem como as pesquisas que buscam compreender o papel dos mediadores (físicos ou semi-óticos) na aprendizagem.

Com essa diferenciação, procurou-se realizar um mapeamento do campo de pesquisa em aprendizagem em museus de ciências, por meio de uma primeira análise quantitativa desses dados e um posterior aprofundamento qualitativo nas pesquisas mais representativas entre os especialistas da área ${ }^{9}$.

\footnotetext{
${ }^{9}$ Consideram-se como pesquisas mais representativas aquelas mais continuamente citadas pelos pares, assim como as que foram utilizadas em outras pesquisas como modelo teórico.
} 


\subsubsection{O que diziam os pesquisadores?}

Considerando-se as três fontes de dados consultadas, foram obtidos 145 trabalhos sobre aprendizagem em museus, sendo a maioria artigos de periódicos científicos $(71,3 \%)$. Livros e capítulos de livros também aparecem relativamente bem representados (20,7\%), constituindo-se em fontes importantes de disseminação da pesquisa científica sobre aprendizagem nesses contextos educacionais. As dissertações e teses sobre o tema, entretanto, apresentaram-se em número limitado, provavelmente pela restrição das ferramentas de busca ou pela relativa juventude da pesquisa na área no cenário nacional.

A grande maioria das publicações aparece após 1995. Esse aumento significativo no número de trabalhos poderia estar relacionado ao fato de que parte das revistas eletrônicas disponibiliza on-line somente seus volumes mais recentes. Entretanto, o número de citações obtidas por essa fonte não foi majoritário. Os dados refletem, então, o aumento considerável de pesquisas sobre aprendizagem em museus, repetidamente citado por diversos autores (FALK, 2001; HOOPER-GREENHILL, 1999a; RENNIE; JOHNSTON, 2004).

Esse movimento em direção ao tema "aprendizagem" já foi observado nas pesquisas desenvolvidas no contexto escolar, principalmente na década de 1970, quando as publicações na área de Ensino de Ciências e Matemática referiam-se, em grande número, ao entendimento do processo de aprendizagem nesses ambientes. Atualmente, esse tema deixou de ser prioritário em pesquisas desenvolvidas no ambiente formal, dando espaço a outras questões pertinentes à cultura escolar. Na pesquisa em Museus, entretanto, observa-se ainda um crescimento no número de investigações interessadas em compreender a especificidade dos elementos que envolvem o processo de aprendizagem nesses espaços.

As categorias de agrupamento elaboradas também parecem apoiar essa ideia. A maior parte dos textos (Tabela 1) refere-se a reflexões sobre os principais aportes teóricos e metodológicos da área, buscando continuamente a especificidade desse campo. Os elementos mais comumente citados nos textos como relacionados à aprendizagem (objetos, interatividade, modelos expositivos, público) também são considerados, se não exclusivos, prioritariamente de museus. Alguns autores, como Michel Allard e Suzanne Boucher (1998) e Van-Präet e Poucet (1992) chegam a defender uma pedagogia museal, embasada em aspectos próprios desses contextos: o tempo, o objeto e o espaço. 
Tabela 1 - Trabalhos sobre aprendizagem em museus selecionados para análise e organizados em categorias segundo o tipo de publicação. Os "textos na internet" referem-se aos trabalhos disponibilizados somente em websites, não sendo publicados em periódicos científicos ou livros.

\begin{tabular}{l|c|c|c|c|c}
\hline Categorias & $\begin{array}{c}\text { Artigos } \\
(\mathrm{n}=103)\end{array}$ & $\begin{array}{c}\text { Capítulos/livros } \\
(\mathrm{n}=30)\end{array}$ & $\begin{array}{c}\text { Dissertações } \\
\text { /teses } \\
(\mathrm{n}=7)\end{array}$ & $\begin{array}{c}\text { Textos na } \\
\text { internet } \\
(\mathrm{n}=5)\end{array}$ & $\begin{array}{c}\text { Total } \\
(\mathrm{n}=145)\end{array}$ \\
\hline Modelos & 52 & 15 & 4 & 4 & 75 \\
\hline Públicos & 37 & 8 & 3 & 1 & 49 \\
\hline Mediação & 36 & 12 & 5 & 0 & 53 \\
\hline Total & $\mathbf{1 2 5}$ & $\mathbf{3 5}$ & $\mathbf{1 2}$ & $\mathbf{5}$ & $\mathbf{1 7 7}$ \\
\hline
\end{tabular}

Os outros dois grupos aparecem em números mais restritos. Pesquisas que analisam as práticas dos museus, enfatizando como os aspectos teórico-metodológicos podem servir de fundamentos gerais para a elaboração de investigações que indiquem elementos importantes para a reflexão sobre o papel educativo dos museus, parecem estar tomando corpo nos últimos 15 anos. Esse caminho apresenta-se oposto ao observado nos museus de arte. Para Xanthoudaki, Tickle e Sekules (2003 apud INSULANDER, 2005), esses museus, na década de 1990, investiram esforços qualitativos em suas atividades pedagógicas, resultando em um aumento do profissionalismo e da produção de novas tecnologias nesses espaços. Entretanto, poucas ações resultaram em pesquisas. Os autores observam que, frente a esse quadro, os museus de arte têm-se proposto ao desenvolvimento de pesquisas baseadas na prática educacional dessas instituições. Já nos museus de ciências, pelo escopo dos trabalhos publicados observado, é possível sugerir que a formação de um campo teórico-metodológico na área tem precedido, ou ao menos acompanhado, o desenvolvimento das atividades educativas desses espaços. Mas como estão estruturados esses referenciais teóricometodológicos das pesquisas sobre aprendizagem em museus de ciências? E como esses referenciais dialogam com as práticas educacionais estabelecidas por essas instituições?

Em busca destas respostas, será apresentada uma síntese dos principais trabalhos analisados em cada uma das categorias propostas anteriormente: Modelos Teóricometodológicos, Especificidades de Públicos e Mediação. 


\subsubsection{Modelos Teórico-metodológicos}

Nos 75 trabalhos analisados que buscaram refletir sobre as principais abordagens teóricas e/ou metodológicas utilizadas tanto nas práticas museais quanto nas pesquisas sobre elas, deu-se atenção ao conceito de aprendizagem utilizado durante a investigação (caso ocorra uma definição do termo pelo autor) e à estruturação dessa definição. Buscou-se ainda compreender como esses autores relacionam a aprendizagem aos diferentes contextos educacionais. Em cada trabalho, foi observado se o autor considera, implicitamente, a aprendizagem como elemento diferenciador de contextos educacionais. E, obviamente, procurou-se identificar em que referenciais teórico-metodológicos baseiam-se os diferentes trabalhos analisados.

\section{$\underline{\text { A noção de aprendizagem }}$}

Uma das questões norteadoras desse levantamento bibliográfico foi entender como a aprendizagem é compreendida pelos pesquisadores em educação em museus e quais os principais elementos abordados relacionados à aprendizagem nesses ambientes.

Entre os artigos analisados nessa categoria, poucos apresentaram uma definição de aprendizagem. A maioria dos autores preferiu levantar características da aprendizagem em ambientes não-escolares, ressaltando os principais elementos envolvidos.

A aprendizagem em museus é vista pelos autores desses textos como um processo, mais do que um produto. Em todas as definições encontradas, a continuidade foi expressa, como na definição de Falcão et al. (2003, p. 186), em que a aprendizagem é vista como "um processo de longo prazo que envolve progressos e regressões, muito mais do que simples substituições de ideias" e na de Falk (2001), que vê a aprendizagem como um diálogo entre o indivíduo e o meio, ao longo do tempo. Para esse pesquisador, em outro trabalho em coautoria com Lynn Dierking (FALK; DIERKING, 2000), a aprendizagem é um esforço contextualizado que permite construir significados para sobreviver e prosperar no mundo. Essa construção de significado ocorre por um processo constante em que se relacionam experiências passadas e atuais.

Enquanto a percepção de aprendizagem como processo, além de produto, é bastante aceita entre os pesquisadores estudados, o mesmo não acontece quando se analisa como esse processo ocorre. Enquanto para alguns autores a aprendizagem é um processo prioritariamente mental, para outros ele é social. Para Jeffery-Clay (1998), a aprendizagem se 
dá quando indivíduos mudam estruturas conceituais existentes, criando relações e integrando novos conceitos. Essa posição é semelhante à de Gilbert e Priest (1997), para quem a aprendizagem é o desenvolvimento e o uso de modelos mentais pelos indivíduos, e à de Puchner, Rapoport e Gaskins (2001), em que a aprendizagem envolve mudanças em representações mentais que podem ou não se manifestar no comportamento.

Entretanto, para Allen (2002), a aprendizagem é o ato de interpretar para fazer sentido pessoal, mas como atividade articulada de um grupo. Essa visão é condizente com a perspectiva sociocultural adotada por essa autora em suas pesquisas. Já Leinhardt, Knuston e Crowley (2003, p. 25, tradução nossa), também adeptos da abordagem sociocultural, ancoram sua definição no discurso do visitante e, portanto, definem aprendizagem como elaboração conversacional, em que a linguagem é enriquecida pelos detalhes específicos dos objetos e temas dos museus e reflete as conexões pessoais e afetivas realizadas "de uma maneira que vai além das simples declarações gosto ou não gosto" ou da identificação desses objetos ou temas. Percebe-se assim, que a concepção de aprendizagem desenvolvida por cada autor depende da teoria educacional utilizada na pesquisa e, dessa forma, pode se esperar que não haja uma definição consensual do termo, haja vista a variedade de teorias educacionais utilizadas nos museus de ciências.

Em relação aos elementos envolvidos no processo de aprendizagem em museus, estes também se apresentam variados entre os diferentes autores. É comum a ideia de que, nesses locais, a aprendizagem envolva aspectos afetivos, cognitivos, motores, lúdicos e sociais (ALLEN, 2002; FALCÃO et al., 2003; ROBERTS, 1994) e seja influenciada pela percepção, consciência, emoção e memória do visitante, além do modo como os indivíduos desenvolvem e utilizam processos simbólicos e como a cultura atua no desenvolvimento humano (HOOPER-GREENHILL, 1999b; LIMA, 1997).

Outro elemento bastante citado é o "voluntarismo" da aprendizagem em museus, locais em que o visitante aprende porque quer, representado claramente na ideia de FreeChoice Science Learning desenvolvida por Falk (2001). Esse autor, juntamente com Martin Storksdieck (FALK; STORKSDIECK, 2005a), a partir de centenas de pesquisas na área, tentou sintetizar a miríade de fatores que influenciam e definem a aprendizagem em museus, diferenciando-a de outros contextos educacionais, encontrando 11 conjuntos de fatores ${ }^{10}$ :

\footnotetext{
${ }^{10}$ Em trabalho anterior, Falk e Dierking (2000) elencaram oito conjuntos de fatores que influenciam a aprendizagem em museus. Os apresentados por Falk e Storksdieck (2005a) diferem dos primeiros principalmente em relação ao contexto físico.
} 
Motivação e expectativas

Experiência e conhecimento prévios contexto pessoal

Interesses e crenças

Escolha e controle

Mediação social dentro do grupo 7

Mediação facilitada por outros

contexto sociocultural

Entendimento da mensagem conceitual da exposição

Orientação do espaço físico

Arquitetura e edifício

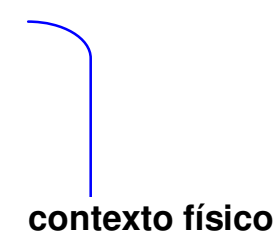

Design das exposições e conteúdo das legendas

Eventos posteriores e experiências fora do museu

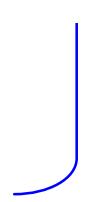

Para os autores, esses fatores contribuem significativamente para a qualidade da experiência museal, mesmo que a importância relativa de cada um deles possa variar entre os visitantes.

Embora seja recorrente essa ideia de que a aprendizagem em museus seja influenciada por uma miríade de fatores (FALK, 2004), há na literatura pesquisas que defendem que algumas características devem ser priorizadas nos estudos sobre aprendizagem em museus (LEINHARDT; KNUSTON; CROWLEY, 2003). Para esses autores, a identidade do visitante, seu engajamento explanatório antes e durante a visita e o ambiente da aprendizagem são os mais relevantes para o desenvolvimento de Elaborações Conversacionais, consideradas por eles como a unidade de aprendizagem no museu.

\section{$\underline{\text { Os contextos de aprendizagem }}$}

A totalidade dos textos analisados parte do pressuposto de que ocorre aprendizagem em museus. Mesmo os autores que colocam em dúvida essa ocorrência, ao longo do texto assumem que os museus são espaços de aprendizagem. A questão deixa de ser, então, 'se há ou não aprendizagem em museus' e passa a ser 'se há diferenças entre a aprendizagem que 
ocorre em museus e em outros ambientes (principalmente o escolar)'. Para autores como Lima (1997), não há diferenças entre o processo de aprendizagem que ocorre na escola ou fora dela. Para ela, o que difere é o conhecimento a ser aprendido e os procedimentos de aprendizagem utilizados em cada ambiente. Já para Van-Praët (1998) e Van-Praët e Poucet (1992), há especificidades da aprendizagem em museus, principalmente em função da relação entre o aprendiz e o objeto.

As distinções apresentadas mostram ainda nuances de variação na produção científica de um mesmo autor. John Falk (2001), por exemplo, coloca que não há evidências de que a aprendizagem seja diferente em ambiente formais e informais, quando se consideram somente as variações de contexto físico (a aprendizagem de um aluno sentado em um banco de museu não diferiria em nada de um aluno sentado em uma carteira escolar se a atividade desenvolvida fosse a mesma). Entretanto, em artigo posterior (FALK; STORKSDIECK, 2005a, p. 120, tradução nossa), ressalta que a aprendizagem é altamente situada e que a aprendizagem em museus é diferente da aprendizagem em qualquer outro local em virtude da "natureza única do contexto museal". Assim, por ser altamente situada, a aprendizagem em um museu em São Paulo seria diferente da aprendizagem em um museu em Manaus.

Muitos dos trabalhos considerados neste mapeamento adotam a abordagem sociocultural em suas investigações. Portanto, quando o foco de pesquisa migra do indivíduo para o social e, principalmente, para as interações sociais, a concepção de que a aprendizagem deixa de ser um processo exclusivamente de construção individual e passa a ser uma construção de significado a partir de mediações estabelecidas leva muitos autores a consideram esse processo como diferenciado entre os diversos contextos educacionais. Assim, em uma perspectiva sociocultural, a aprendizagem nos diferentes espaços, sejam eles, museus, escolas, jornais, TVs, família ou outros, diferem em função dos elementos de mediação apresentados nesses contextos.

\section{Referenciais teóricos e/ou metodológicos}

Dos 75 textos analisados, a maioria apresentou referenciais teóricos de pesquisa. Foram encontrados tanto artigos que refletem sobre teorias a serem utilizadas nas pesquisas em museus, quanto textos que descrevem os referenciais da própria pesquisa apresentada ou analisam os referencias utilizados pelos museus em suas atividades educativas.

Em relação aos referencias teóricos adotados pelos museus, vale ressaltar o trabalho de Hein (1998). Esse autor, ao estudar os mecanismos de comunicação em museus, aponta uma 
discussão sobre as teorias educacionais vigentes nesses espaços, utilizadas conscientemente ou não. Para Hein, compreender as teorias educacionais envolvidas no espaço museal requer o entendimento de dois componentes: uma teoria do conhecimento e uma teoria da aprendizagem. Quanto à teoria do conhecimento, o autor acredita que os museus podem se posicionar em um contínuo entre "o conhecimento existe independentemente do aprendiz (HEIN, 1998, p. 22)" e "o conhecimento existe somente em ideias construídas na mente". No caso da aprendizagem, situam-se no contínuo entre "a aprendizagem consiste em um acúmulo constante de informações, fatos e experiências (resultando em conhecimento)" e "aprendizagem consiste da seleção e organização de sensações do entorno, com a construção de esquemas mentais". Para o autor, essas duas dimensões das teorias educacionais podem ser combinadas, produzindo diferentes posturas em relação à educação.

Nesse livro, Hein caracteriza diferentes posições, representadas em diferentes tipos de museus, ressaltando que o museu tradicional, sistemático, com características behavioristas, é o mais familiar entre diversos países. Nesses museus, acredita-se que o acervo pode ser exibido de forma a representar a estrutura "verdadeira" do conteúdo conceitual, de uma maneira que seja mais "facilmente" compreendido. Contraposto a esse tipo de museu está o museu construtivista, em que o visitante constrói o conhecimento a partir da exposição e o processo de apropriação do conhecimento é em si um "ato de construção". Entretanto, em uma visão contrária a de Hein, Hooper-Greenhill (1999c) pondera que, atualmente, são poucos os educadores de museu que não adotam essa segunda postura. Sugere que não existe um consenso sobre a melhor abordagem educativa em museus e, frente à diversidade de comunidades interpretativas entre a audiência, indica a necessidade de um número maior de pesquisas nessa área.

Ao se olhar para as teorias e metodologias utilizadas no campo da pesquisa, foram observados nove modelos ou abordagens teórico-metodológicos citados pelos autores dos trabalhos analisados ${ }^{11}$, sendo o Modelo de Aprendizagem Contextual e as abordagens construtivistas e socioculturais os mais utilizados.

O Modelo de Aprendizagem Contextual, desenvolvido principalmente pelos pesquisadores estadunidenses John Falk e Lynn Dierking ${ }^{12}$, do Institute for Learning Innovation, é citado principalmente por pesquisadores desse país. Baseia-se na ideia de Free-

\footnotetext{
${ }^{11}$ Modelo de Aprendizagem Contextual, Abordagem Construtivista, Abordagem Sociocultural, Educação Experimental, "Progressive Education", Modelos Mentais e de Modelagem, "Personal Awareness of Science and Technology", Construcionismo, Testes Psicográfigos.

${ }^{12}$ Esse modelo é apresentado de forma detalhada em: FALK, J.; DIERKING, L. Learning from Museus:

Visitors Experiences and the Making of Meaning. Walnut Creek: Altamira Press. 2000. 272 p.
} 
Choice Learning, em que a aprendizagem é de livre escolha, voluntária e não seqüencial, e deriva do Modelo de Experiência Interativa, apresentado pelos mesmos autores oito anos antes (FALK; DIERKING, 1992). Segundo eles, o Modelo Contextual de Aprendizagem

propõe que toda aprendizagem é situada em uma série de contextos. Em outras palavras, aprendizagem não é somente uma experiência abstrata que pode ser isolada em um tubo de ensaio ou um laboratório, mas sim, uma experiência orgânica, integrada, que acontece no mundo real. Nós [os autores] argumentamos que a aprendizagem é um produto de milhões de anos de evolução, uma adaptação que permite o diálogo contínuo ente o indivíduo e o mundo físico e sociocultural em que vive (FALK; DIERKING, 2000, p. 10, tradução nossa).

Os trabalhos embasados por esse referencial teórico (e.g., FALK, 2001, 2004; FALK; STORKSDIECK, 2005a,b; RENNIE; JOHNSTON, 2004) enfatizam que a aprendizagem é altamente situada e, portanto, dependente dos contextos pessoais, socioculturais e físicos. Dessa forma, o design metodológico das pesquisas realizadas por esses autores passa a ser a verificação do grau de influência de cada um dos fatores, analisados separada ou holisticamente. Um exemplo de observação de vários aspectos simultaneamente é o trabalho de Falk e Storksdieck (2005a), em que realizam uma análise multivariada de dez fatores que podem influenciar a aprendizagem em museus ${ }^{13}$. Ao observarem e entrevistarem 217 visitantes adultos em uma exposição do California Science Center, os autores concluem que nenhuma das dez variáveis analisadas por si só explicaria as "mudanças de aprendizagem" encontradas. Assim, ressaltam a importância dos estudos que consideram um maior número de fatores em suas análises.

O Modelo Contextual, ao utilizar-se da 'situabilidade' como elemento chave, pode ser visto como uma variação das ideias de Lave e Wanger (1991) sobre aprendizagem situada, em que a aprendizagem é resultado da atividade humana e dependente do contexto e dos aspectos culturais em que ocorre. Como os próprios autores do modelo afirmam, ele "derivou de observações de pessoas reais em contextos reais, então, não será surpreendente se outros pensadores, antes ou depois, considerem modelos similares a este" (FALK; DIERKING, 2000, p. 10, tradução nossa). Em artigo posterior, Falk (2004, p. S86) intitula o Modelo Contextual como "construtivismo-inspirado".

\footnotetext{
${ }^{13}$ As variáveis analisadas nesse artigo são: expectativas e motivações, conhecimento prévio, interesse prévio, escolha e controle, interações dentro do grupo social, mediação facilitada por outros, entendimento da mensagem conceitual da exposição, orientação, arquitetura e espaço físico e design.
} 
A abordagem construtivista também foi observada como amplamente aceita pelos pesquisadores de educação em museus e, como observado, teve adesão também outros países. $\mathrm{Na}$ Inglaterra, por exemplo, Eilean Hooper-Grenhill, pesquisadora sobre comunicação em museus (principalmente de história e arte), utiliza essa abordagem de pesquisa em algumas de suas investigações. O construtivismo é utilizado nas pesquisas em museus principalmente devido à teoria de equilibração de Piaget e por enfatizar a importância do conhecimento prévio e do envolvimento pessoal na construção do conhecimento (e.g., ANDERSON; LUCAS; GINNS, 2003; HEIN, 1998; HOOPER-GREENHILL, 1999a,b; JEFFERY-CLAY, 1998; PUCHNER; RAPOPORT; GASKINS, 2001). Entretanto, presentes também são as críticas a esse modelo, encarado como uma "filosofia espalhada na escola e com risco de se espalhar pelos museus" (OSBORNE, 1998, p. 8, tradução nossa), sugerindo a produção de outras linhas de pesquisa, como o "construcionismo" abordado por Osberg (1998) e bastante aceito no México ${ }^{14}$.

A abordagem sociocultural ${ }^{15}$ também é referenciada pelos pesquisadores e comumente é citada como uma perspectiva em grande expansão nos estudos de aprendizagem em museus (e.g., ALLEN, 1997a; ELLENBOGEN; LUKE; DIERKING, 2004; LEINHARDT; KNUSTON; CROWLEY, 2003; SCHAUBLE; LEINHARDT; MARTIN, 1997). Como colocam Schauble, Leinhardt e Martin (1997, p. 5, tradução nossa), essa abordagem “jogou luz na variabilidade da aprendizagem, no processo de aprendizagem e no papel da aprendizagem na história pessoal e na busca do significado". Para as autoras, a Teoria Sociocultural representa o arcabouço teórico que melhor organizaria as agendas de pesquisa dos museus, suavizando a incoerência ainda existente entre a nova imagem desses espaços (como instituições de papel multifacetado que convidam o visitante a aprender e se emocionar em suas interações sociais) e a pesquisa científica desenvolvida nesses espaços (que ainda estaria atrelada aos mecanismos avaliativos do espaço escolar).

\footnotetext{
${ }^{14}$ Ambas as propostas, o construtivismo e o construcionismo, descartam a ideia de conhecimento como reflexo de uma realidade ontológica, definem o conhecimento como uma construção e afirmam que somente é possível aprender por meio de experiências. Ambas ressaltam que o conhecimento é construído preferivelmente que transferido, mas enquanto o construtivismo tende a ver cada sujeito como inventor do mundo, o construcionismo foca, em relação à construção da realidade, na "interação e intercâmbio social através da linguagem que dá diferentes significados às coisas, eventos e pessoas em nossas vidas e em nós mesmos" (NOSTI, 2005).

${ }^{15}$ Alguns autores de trabalhos de revisão na área de Aprendizagem em Museus localizam as teorias socioculturais dentro de um grupo mais amplo denominado de "Construtivismo" (e.g., HEIN, 1998). Entretanto, a grande maioria, ao relacionar os principais referencias teóricos abordados nas pesquisas em museus, separa o Construtivismo da Teoria Sociocultural (e.g., FALK; DIERKING, 2000; RENNIE et al., 2003; INSULANDER, 2005). Nesse trabalho, foram consideradas em "abordagem sociocultural" pesquisas identificadas por seus autores como sociocultural, histórico-cultural e sócio-histórico-cultural.
} 
Ao considerar que o processo de aprendizagem emerge durante a interação entre indivíduos (atuando em um contexto social) e os mediadores (incluindo ferramentas, conversações, estruturas de atividade, signos e sistemas simbólicos), a abordagem sociocultural vem ao encontro dos pesquisadores que procuram analisar a aprendizagem como processo estabelecido no meio social. Assim, elementos como Zona de Desenvolvimento Imediato e, principalmente, as conversas de aprendizagem são possibilidades de análise utilizadas em pesquisas em aprendizagem em museus de ciências que adotam esta perspectiva (e.g., ALLEN, 2002; ASH; LEVITT, 2003; GARCIA, 2006; GASPAR, 1993; GASPAR \& HAMBURGER, 1998; LIMA, 1997; PUCHNER; RAPOPORT; GASKINS, 2001; SAPIRAS, 2007).

A maior parte dos autores que utilizaram essa abordagem (60\%) valeu-se também de aportes teóricos de outras áreas, como as Ciências Cognitivas, a Psicologia e a Antropologia. Laura Martin (2004), por exemplo, afirma que a consideração da atividade de aprendizagem como um sistema deriva da Teoria da Atividade, uma variante da Psicologia Sociocultural sugerida para futuras pesquisas (INSULANDER, 2005; MATUSOV; ROGOFF, 1995; ROWE, 2002).

Esses construtos apóiam as ideias de Paris e Ash (2000), segundo os quais a área de aprendizagem em museus encontra-se em um constante balanço entre importação e exportação de teorias de e para outras áreas de conhecimento.

Vale ressaltar a variedade de referenciais encontrada: nove "modelos" ou abordagens em 75 textos. Além dos já apresentados, outros são conhecidos em outras áreas, como a "Educação Experimental”, cujo expoente mais reconhecido entre os museus é John Dewey, o "Progressive Education”. Outros são construídos dentro da própria área, como o Personal Awareness of Science and Technology (PAST), proposto por Stocklmayer e Gilbert (2002). Há, ainda, os que aparecem em um grupo restrito de publicações por curto período de tempo, como os testes psicográficos que definem tipos de personalidades de aprendizes ou pesquisas de mercado que categorizam perfis de consumidores, no caso, de exposições.

Esses resultados são congruentes com as ideias da pesquisadora inglesa Paulette McMannus que, em curso ministrado na Faculdade de Educação da Universidade de São Paulo $^{16}$, elencou as principais teorias de aprendizagem que influenciam as pesquisas em museus: Inteligências Múltiplas, Behaviorismo, Cognitivismo, Construtivismo (incluindo as

\footnotetext{
${ }^{16}$ Curso de Pós-Graduação "Educação em Museus: Pesquisas e Práticas”, ministrado por Martha Marandino e Paulette McManus, em setembro de 2005.
} 
ideias, para a autora, socioculturais de Vigotski), Aprendizagem por Descoberta e Concepções Binárias de Personalidade (teorias de comportamento importadas da Psicologia).

Essa diversidade de referenciais teórico-metodológicos reflete-se na variedade de estratégias de coleta de dados encontradas nas pesquisas levantadas. A escolha de um determinado referencial influencia sobremaneira os mecanismos de aproximação dos objetos de estudo. Assim, nas investigações em que o Modelo Contextual ou o Construtivismo foram utilizados para delineamento da pesquisa, observou-se com freqüência o uso de questionários (e.g., KORN, 1995), entrevistas pré e/ou pós-visita (e.g., FALK; DIERKING, 1997), a Lembrança Estimulada com uso de vídeo (e.g., GASPAR, 1993) ou fotografias (e.g., FALCÃO, 1999) e o Personal Meaning Mapping ${ }^{17}$ (e.g., FALK et al., 2004). Em geral, essas pesquisas apresentam uma abordagem múltipla, conjugando simultaneamente diferentes estratégias.

Alguns artigos lançam mão de ferramentas como "Time" e "Tracking" (cf. DIAMOND, 1999), utilizadas geralmente para observação do uso de exposições pelos visitantes, relacionando-as à aprendizagem (e.g., BOISVERT; SLEZ, 1994; 1995). Nesses estudos, é considerado que a aprendizagem do visitante ocorre em função do tempo gasto, do percurso realizado e do engajamento apresentados por ele, geralmente relacionados ao Poder de Atração e de Retenção das exposições. Entretanto, relacionar os trajetos realizados pelo visitante e o tempo gasto em cada aparato ao aprendizado apresentado após a visita é uma proposta encontrada com maior freqüência em pesquisas não tão recentes (e.g., ZOLCSAK et al., 1988).

Para Falk (2004), em uma crítica a esses estudos, essas estratégias metodológicas estão associadas a pesquisas baseadas em modelos behavioristas de aprendizagem, os quais postulam que dado o estímulo certo (como um aparato atrativo), o visitante dará a resposta certa (aprendeu o que o museu gostaria que ele aprendesse). Ele traz sua crítica a pesquisadores mais atuais que "continuam focando muito de suas energias em compreender o papel que objetos, legendas ou aparatos possuem no comportamento e na aprendizagem do visitante" (FALK, 2004, p. S84, tradução nossa), citando, por exemplo, Allen (1997b) e Serrell (1997).

\footnotetext{
${ }^{17} \mathrm{O}$ Personal Meaning Mapping (PMM) é uma ferramenta desenvolvida pelo Institute for Learning Innovation (EUA), utilizada para medir e avaliar a aprendizagem em contextos informais de educação, apresentando similaridades com o "Mapa de Conceito". A premissa principal do PMM não é o que um visitante aprende, mas o quanto ele aprende.
} 
Entretanto, essas investigações podem ser consideradas como imersas em um conjunto de estudos que ajudou e vem ajudando (e. g., ALLEN, 2004) a caracterizar o campo de pesquisa sobre aprendizagem em museus. A partir desses estudos, por exemplo, emergiu a necessidade de pesquisas que enfocassem também os aspectos sociais do processo de aprendizagem. Nesse sentido, o referencial sociocultural passou a ser bastante utilizado em uma série de estudos desenvolvidos por e nos museus, alargando o número de ferramentas de coleta de dados. O foco dado à interação estabelecida dentro do grupo de visitantes, bem como deste com mediadores externos ao grupo (seja na interação com objetos ou na interação sujeito-sujeito) aumentou, por exemplo, a freqüência de utilização de ferramentas metodológicas como a gravação de áudio e vídeo para a análise de conversas estabelecidas durante e após (imediatamente ou não) a visita (e. g., ALLEN, 2002; ASH, 2003; GARCIA, 2006; LEINHARDT; KNUSTON; CROWLEY, 2003; RAHM, 2004; SAPIRAS, 2007; TUNNICLIFFE, 2000). Além disso, promoveu a possibilidade de novas estratégias metodológicas, como a utilizada por Fors (2004), que disponibilizou filmadoras para adolescentes de 15 anos registrarem sua visita ao The House of Technology, no norte da Suécia. Com isso, o autor pretendia não somente observar as diferentes práticas apresentadas pelos jovens, mas também compreender como eles usam o vídeo para representarem a si mesmos quando demonstram e falam sobre sua experiência museal.

Observa-se assim que o campo de pesquisa em aprendizagem em museus de ciências apresenta-se estruturado, com referenciais teórico-metodológicos claros, compartilhados e discutidos entre os profissionais da área, em contínuos fortalecimentos e reformulações. As convergências e divergências de objetos de estudos e de reflexões sobre o campo encontradas remetem-nos à ideia de que a contínua negociação entre os pesquisadores apresentou-se fundamental para a construção e o fortalecimento da área.

\subsubsection{Especificidade de públicos}

Embora em menor quantidade que os trabalhos que refletem sobre os referenciais teórico-metodológicos da área de aprendizagem em museus de ciências, um grupo significativo de textos procura, como ressalta Kelly (2003, p. 362, tradução nossa), "compreender a aprendizagem em museus pela perspectiva do visitante" ${ }^{18}$. Assim, observa-se

\footnotetext{
${ }^{18}$ Vale ressaltar que a distinção entre as categorias aqui propostas não é estanque e muitas vezes uma mesma publicação poderia ser integrada a uma ou outra categoria. Para uma tomada de decisão, foi considerado o foco do trabalho.
} 
na literatura analisada uma série de investigações focadas em públicos determinados, procurando identificar elementos específicos de cada um deles, sendo os públicos escolar e familiar os mais estudados. Em suplemento publicado recentemente pelo periódico estadunidense Science Education ${ }^{19}$, são encontrados dois artigos relacionados especificamente a esses públicos. Em um deles, Janette Griffin (2004) procura levantar quais os principais elementos realçados pelos estudos sobre a aprendizagem de estudantes em museus de ciências e, em outro, Kirsten Ellenbogen, Jessica Luke e Lynn Dierking (2004) defendem a emergência de uma nova matriz disciplinar, a Pesquisa em Aprendizagem Familiar.

Para Griffin (2004), a pesquisa sobre grupos escolares em museus, ao mudar seu objeto de estudo, preterindo as concepções dos estudantes aos seus comportamentos de aprendizagem socialmente negociados, e ao olhar para a interação entre aprendizagem na sala de aula e nos museus, promoveu um grande entendimento sobre o processo de aprendizagem nesses contextos.

A autora aponta três questões que guiaram as pesquisas na área a partir dos anos 1990:

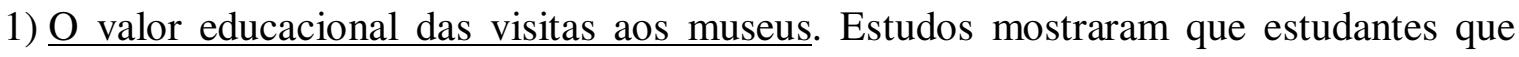
visitam museus têm maior motivação e ganho cognitivo. Entretanto, alguns artigos contradizem essa ideia e a autora conclui que as visitas a museus podem promover resultados controversos, que dependem do contexto em que essas visitas ocorrem.

2) $\underline{O}$ impacto da preparação anterior às visitas. Os estudos sobre o conhecimento prévio de estudantes, a preparação específica na classe e a orientação para a visita foram relacionados na literatura, segundo a autora, como os principais promotores de possibilidade de ocorrência de aprendizagem, principalmente nos casos em que há maior integração museu/escola.

3) A complexidade dos elementos que influenciam aprendizagem. As investigações mostraram que os museus oferecem uma gama de oportunidades de envolvimento do aluno e que a possibilidade de interação entre alunos, professores e museus pode levar a experiências museais mais ricas.

Para a autora, as pesquisas analisadas refletem um aumento de interesse em estudos sobre escolares em museus, ressaltando que há uma mudança de foco de análise: estudos recentes deixaram de considerar o grupo inteiro de estudantes e passaram a centralizar suas investigações sobre a aprendizagem de um aluno dentro de um grupo. Nesse levantamento, a

\footnotetext{
${ }^{19}$ Science Education, New York, vol. 88, n. S1, jul. 2004.
} 
autora enfatiza também que os estudantes dão valor ao seu poder de escolha e controle durante a visita. Essa última conclusão torna-se um importante ponto de reflexão quando se consideram os resultados encontrados por Griffin (1994) em seus estudos sobre o uso de exposições por professores e alunos. Para a autora, as estratégias utilizadas pelos professores que tentam impor as regras da escola aos museus acabam por limitar as possibilidades de interação entre estudante e exposição. Em seu "Guia Prático para Avaliação em Museus", Gammon (2001) sugere outros impedimentos para a aprendizagem nesses espaços e coloca as atividades que não estimulam a continuidade e que são pouco relacionadas com as habilidades dos visitantes como elementos que influenciam negativamente a aprendizagem dos escolares em visita a esses ambientes.

A pesquisa voltada para o público escolar também tem apresentado um aumento no uso da teoria sociocultural como referencial teórico-metodológico. Estudos como os de Garcia (2005) e Sapiras (2007) investigam as interações conversacionais estabelecidas dentro de um grupo de estudantes e entre eles e o monitor de espaços museais, ambos apoiados nas categorias de conversa propostas por Allen (2002). No primeiro estudo, a autora, ao analisar a atividade de visita orientada em um jardim zoológico, ressalta que as conversas estabelecidas entre os participantes da atividade basearam-se principalmente na taxonomia dos animais observados e em menor grau nos elementos de conservação propostos pela equipe do museu. No segundo, a autora coloca a conversa conceitual como a mais freqüente, seguida pelas perceptiva, estratégica, afetiva e conectiva, relacionando esses resultados com o fato de que, no museu pesquisado, a visão de animais vivos pode ter estimulado questionamentos entre estudantes e monitores, facilitando a conversa conceitual.

Pesquisas como essas, que procuram compreender a aprendizagem de grupos provenientes de um contexto formal em espaços não formais, contribuem para os encaminhamentos de pesquisa propostos por Griffin (2004), de uma transposição da barreira entre a aprendizagem em escolas e em museus, estabelecendo ligações claras, genuínas e contínuas que possibilitem a aprendizagem efetiva de estudantes nos dois contextos. Ainda nessa perspectiva, a autora sugere que os estudos sobre aprendizagem em família podem ajudar a compreender os processos de aprendizagem estabelecidos por estudantes durante as suas visitas aos museus de ciências.

A literatura voltada para a investigação sobre os processos de aprendizagem desenvolvidos por grupos familiares em museus é extensa. Para Ellenbogen, Luke e Dierking (2004), há crenças, linguagem e valores compartilhados entre os pesquisadores em 
aprendizagem familiar, há pressupostos disciplinares sobre a metodologia de pesquisa, há cada vez mais um maior entendimento da família como uma instituição de aprendizagem. Com esse conjunto de elementos, as autoras defendem que existe uma matriz disciplinar ${ }^{20}$ emergente, a Pesquisa em Aprendizagem Familiar em Museus (Family Learning Research in Museums).

As pesquisas produzidas na década de 1980 geraram resultados que permitiram compreender como as famílias interagem e sobre o que conversam em relação aos tópicos dos programas e exposições avaliados (e.g., MCMANUS, 1988). Esses estudos sugerem que as famílias conversam sobre aquilo que elas sabem de experiências prévias, discutem o que veem, leem, escutam e fazem baseadas nas suas memórias e experiências, compartilhando um conjunto de valores, vocabulário, compreensões e pressupostos (ELLENBOGEN; LUKE; DIERKING, 2004).

A esses trabalhos somaram-se aqueles que procuraram estabelecer metodologias de pesquisa que fortalecessem as relações entre a aprendizagem e os comportamentos observados (as primeiras pesquisas, embora já realizassem análises conversacionais, ainda enfocavam os comportamentos observáveis como indicadores de aprendizagem). Borun, Chambers e Cleghorn (1996), por exemplo, procuraram estabelecer níveis de aprendizagem (a partir de entrevistas e conversas de família gravadas em áudio) e relacionaram esses níveis de aprendizagem aos comportamentos que as famílias apresentaram durante a visita. Ao agrupar esses comportamentos como indicadores de "performance", seria possível distinguir os níveis de aprendizagem e compor uma ferramenta para medir a aprendizagem na visita à exposição.

Outros autores procuram definir categorias baseadas não somente no uso da exposição, mas nas formas de interação dentro do grupo familiar. Brown (1995), em estudo realizado no Exploratory, em Bristol (Inglaterra), encontrou oito padrões de comportamento parental em visitas a esse museu interativo: desde os que apenas acompanham de longe seus filhos até os que executam a tarefa por eles.

Com o avanço da perspectiva sociocultural entre os pesquisadores de aprendizagem em museus, a análise das interações conversacionais ganhou força e profundidade e iniciou um conjunto de investigações preocupado em compreender o papel dos museus na construção da identidade da família. Crowley et al. (2001a), por exemplo, procuraram evidenciar nas

\footnotetext{
${ }^{20}$ Referem-se ao conceito proposto por Kuhn para descrever o conjunto teórico, metodológico e avaliativo em que uma comunidade de pesquisadores atua. A Matriz Disciplinar á definida por crenças e valores compartilhados, pressupostos sobre como conduzir as pesquisas, interesses comuns em problemas similares e aceitação de um espectro particular de soluções.
} 
conversas estabelecidas os modos de interação entre pais e filhos. Para os autores, os pais podem descrever evidências, dar direcionamentos ou fazer explanações que possibilitam uma maior compreensão das atividades pelos filhos. Quando as crianças interagem com uma exposição em companhia de seus pais, observa-se uma exploração de evidências de maior intensidade, mais ampla e mais focada.

Estudos como o de Crowley et al. (2001b) também ajudam a compreender os mecanismos interativos dos grupos familiares em museus de ciências. Os autores observaram que os pais, embora levem seus filhos e suas filhas igualmente aos museus, deem orientações e conversem sobre as evidências observadas tantos com meninos quanto com meninas, ainda assim são três vezes mais propensos a darem explanações aos filhos homens. A falta desse "passo crucial" no processo de aprendizagem foi observada mesmo entre grupos com crianças de 01 a 03 anos de idade.

Em uma dissertação bastante citada na literatura, "From Dioramas to the Dinner Table: an Ethnographic Case Study of the Role of Science Museums in Family Life", Ellenbogen (2003 apud INSULANDER, 2005) acompanhou quatro famílias durante 18 meses em suas visitas a museus ou outros espaços culturais e em incursões em suas próprias casas para compreender a importância dos museus para a aprendizagem e para a vida da família. Os resultados mostraram que a participação em diferentes atividades relacionadas às ciências naturais não somente forma um entendimento conceitual dessas ciências como também contribui com a construção de sua identidade.

Ellenbogen, Luke e Dierking (2004) trazem uma perspectiva bastante interessante da pesquisa sobre aprendizagem familiar em museus: para elas, está ocorrendo uma revolução copernicana no tratamento de famílias em museus. Nesse movimento, as famílias deixam de ser vistas como participantes da agenda dos museus e os museus passam a fazer parte da agenda da família. O ponto de vista é invertido, olha-se a família a partir dela mesma e não do museu.

Além das pesquisas sobre grupos escolares e famílias, encontram-se ainda aquelas preocupadas em entender como algumas características da experiência museal influenciam a aprendizagem dos públicos em geral em museus. Assim, estudos sobre a importância da agenda do visitante (e.g., FALK; MOUSSOURI; COULSON, 1998), das suas experiências satisfatórias (e. g., PEKARIK; DOERING; KARNS, 1999), da motivação (e. g., CSIKSZENTMIHALYI; HERMANSON, 1995; TRAN, 2007) e de suas experiências prévias (e. g., FALK; ADELMAN, 2003) em sua aprendizagem nos museus apresentam-se com 
variedade de referenciais teóricos, mas similitudes de resultados (em geral, apresentam uma relação positiva entre a variável e a aprendizagem nos museus).

\subsubsection{Mediação}

$\mathrm{Na}$ literatura analisada, há um conjunto de estudos que busca compreender o papel dos mediadores, sejam eles semióticos ou humanos, na aprendizagem museal. O foco não está no visitante, mas sim no discurso expositivo (cf. MARANDINO, 2001). Assim, questões como “qual o papel do conteúdo temático da exposição em relação à aprendizagem?”, "qual a importância da mediação sujeito-sujeito para esse processo?", "por que alguns formatos de exposição propiciam maiores possibilidades de aprendizagem?" ou "como a diversidade de fatores relacionados ao discurso expositivo influencia esse processo?" são investigadas por pesquisadores da área há anos.

Dentre os trabalhos considerados, dois objetos de estudo podem ser rapidamente localizados: a interatividade e a aprendizagem baseada em objetos.

A relação entre objetos, visitantes e museus tem sido considerada um "dos tópicos mais importantes para nosso entendimento de como os museus funcionam como espaços educativos, culturais e de lazer" (FALK, 2002, p. xi, tradução nossa). Scott Paris ${ }^{21}$, em 2002, editou uma obra em que 30 diferentes pesquisadores apresentam seus estudos sobre a aprendizagem baseada em objetos. Para o autor, esses estudos se justificam na presença de uma relativamente nova área de pesquisa para psicólogos e educadores que, embora nova, tem precedentes antigos: curadores e educadores de museus estudam os objetos e sua exibição desde o século XIX; antropólogos, considerando os objetos como evidências da cultura material, construíram teorias sobre eles e seus significados; psicólogos estudam os comportamentos dos visitantes de museus desde a década de 1920; diversos educadores ressaltam a importância do manuseio de objetos para a aprendizagem e filósofos têm enfatizado o valor da experiência educativa baseada em objetos genuínos. Assim, o histórico da educação baseada em objetos tem "uma história longa e multidisciplinar" (FALK, 2002, p. xvi, tradução nossa).

As pesquisas recentes na área têm se preocupado em compreender como as pessoas leem os objetos nos museus e quais as interpretações e significados que elas constroem a

\footnotetext{
${ }^{21}$ PARIS, S. (Ed.). Perspectives on object-centered learning in museums. London: Lawrence Erlbaum Associates, 2002. 408p.
} 
partir deles (e.g., ROWE, 2002). Algumas olham para o contexto, tentando compreender o papel das instituições museais na aprendizagem sobre, por meio de e com o objeto (e. g., MICHENER; SCHULTZ, 2002). Outras buscam entender a natureza das interações, principalmente discursivas, baseadas no objeto (e. g., BORUN, 2002; LEINHARDT; CROWLEY, 2002).

Em relação aos estudos sobre a mediação sujeito-sujeito, poucos foram os artigos encontrados. Schauble et al. (2002) aprofundaram-se nos níveis de mediação humana na aprendizagem em museus e concluíram que a "boa mediação", seja pela equipe do museu ou por professores, tem que estar baseada em como os visitantes pensam e como valoram a aprendizagem que ocorre nesses espaços.

Cazelli, Marandino e Studart (2003, p. 100), ao abordarem "a questão da aprendizagem e da mediação nos museus de ciências", ressaltam a necessidade de investigarmos não somente as práticas de professores ao se utilizarem dos espaços museais, identificando os saberes envolvidos nesses processos, mas também de nos questionarmos sobre a formação de profissionais responsáveis pela elaboração das atividades voltadas para o público. Enfatizam que se deve "ter o cuidado de pensar qual o papel da mediação humana na aprendizagem em museus de ciências", pois, "por um lado, as exposições não podem depender de monitores para serem compreendidas, mas por outro, talvez seja a mediação humana a melhor forma de obter um aprendizado mais próximo do saber científico" (CAZELLI; MARANDINO; STUDART, p. 101). Recentemente, Marandino et al. (2008) apresentaram uma compilação de estudos relacionados à prática dos mediadores de museus, relacionado-as com aspectos da aprendizagem.

\subsubsection{Os grupos de pesquisa}

Entre os artigos encontrados, alguns grupos de pesquisa em aprendizagem em museus possuem maior freqüência de publicação e (conseqüentemente ou devido a) uma maior citação entre a comunidade de pesquisadores da área. Foram selecionados alguns deles para apresentação neste trabalho, tanto internacionais quanto nacionais, já que a produção oriunda de suas investigações tem tido grande impacto sobre as pesquisas na área.

AMARC - Australian Museum Audience Research Centre. O grupo de pesquisa australiano desenvolve pesquisas de público e programas de avaliação em museus, 
coordenadas por Linda Kelly. Desenvolve ainda atividades comerciais de avaliação de aprendizagem em museus da Austrália.

GEM - Group for Education in Museums. O grupo, sediado em Gillingham, na Inglaterra, é formado por diferentes membros, representantes de museus e galerias, e coordenado por John Reeve. É responsável por publicações importantes na área como o Journal for Education in Museums e o GEM News.

GEENF - Grupo de Estudo e Pesquisa em Educação Não Formal e Divulgação em Ciência. O grupo de pesquisa brasileiro encontra-se sediado na Faculdade de Educação da Universidade de São Paulo e é coordenado por Martha Marandino. Em parceria com instituições museais, desenvolve pesquisa sobre educação não formal e divulgação em ciência.

GREM - Groupe de recherche sur l'éducation et les musées. Situado em Québec, no Canadá, esse grupo é coordenado por Michel Allard e desenvolve estudos sobre a Pedagogia museal, enfocando principalmente a relação museu/escola. Criado em 1981, tem como objetivos elaborar, experimentar, avaliar e validar modelos didáticos propostos aos museus.

ILI - Institute for Learning Innovation. Localizado em Maryland, nos Estados Unidos, o centro é uma organização sem fins lucrativos, criada em 1986 (não está ligado a uma universidade). Conta com pesquisadores como Jéssica Luke e Martin Storcksdieck e tem como diretores eméritos John Falk e Lynn Dierking (editores da Science Education). O centro realiza pesquisas e avaliações em museus estadunidenses, constituindo-se como apoio às instituições que desejam desenvolver maiores possibilidades de aprendizagem para seu público.

MAST - Museu de Astronomia e Ciências Afins. O grupo voltado para o estudo Educação em Museus dessa instituição, coordenado por Douglas Falcão, desenvolve pesquisa em duas linhas principais: Comunicação e Cognição em Museus de Ciências e Alfabetização Científica, Educação em Ciências e Avaliação Educacional.

MER - Museum Education Roundtable. Sediado em Washington, EUA, essa organização sem fins lucrativos promove a pesquisa sobre Educação em Museus, prioritariamente em Museus de Arte. Entretanto, sua publicação Journal of Museum Education é um periódico referencial para pesquisadores de Museus de Ciências.

PERG - Program Evaluation and Research Group. O grupo de pesquisa localizado na Universidade de Lesley, Estados Unidos, desenvolve desde 1976 programas de avaliação de 
aprendizagem em contextos formais e não formais de educação. George Hein é professor emérito dessa universidade e ligado a esse centro de pesquisa.

RCMG - Research Centre for Museums and Galleries. Ativo desde 1999, o grupo do Departamento de Estudos em Museus (responsável pela publicação Museological Review), da Universidade de Leicester, na Inglaterra, é comandado por Eilean Hooper-Greenhill, e desenvolve uma série de pesquisas sobre museus e galerias, sendo a aprendizagem nesses espaços um de seus objetos de estudo.

\section{UPCLOSE - University of Pittsburgh Center for Learning in Out-of-School}

Environments. Originado do projeto Museum Learning Collaborative, finalizado em 2003, o centro desenvolve estudos sobre aprendizagem em ambientes externos à escola, embasado prioritariamente em uma perspectiva sociocultural de análise de elaborações conversacionais em ambientes não formais. Dirigido por Kevin Crowley, tem focado também os estudos com famílias em museus. Mantém o sítio "www.informalscience.org", um excelente banco de dados sobre pesquisas em aprendizagem em diferentes espaços educativos.

WIT - Work, Interaction and Technology. Grupo de pesquisa interdisciplinar do Department of Management, do King's College, em Londres, Inglaterra. Dirigido por Christian Heath, o grupo especializou-se em pesquisas de campo baseadas em análise de vídeos de interações sociais com o intuito de investigar como objetos e artefatos influenciam a atividade de aprendizagem.

\subsubsection{Algumas conclusões}

Os estudos em Aprendizagem em Museus permitiram, na última década, o estabelecimento de fundamentos teórico-metodológicos, levando a uma maior compreensão de como os visitantes dão significado a suas experiências museais (RENNIE e JOHNSTON, 2004). Percebe-se que essas pesquisas são desenvolvidas principalmente nos Estados Unidos e na Inglaterra e, em menor quantidade, na França, na Espanha e no Canadá. Enquanto as pesquisas estadunidenses estão mais embasadas nos Museus de Ciências (definição que inclui Centros de Ciências, Museus de História Natural, Zoológicos, Jardins Botânicos etc.), as inglesas estão mais relacionadas aos Museus de História e de Arte. Percebe-se ainda que os estudos publicados por centros ingleses apresentam uma maior inovação em termos de ampliação dos referencias teórico-metodológicos utilizados. Os pesquisadores estadunidenses parecem tender a pesquisas mais pragmáticas, que forneçam resultados práticos para a mudança da práxis educativa. Na pesquisa inglesa, parece haver uma tendência em procurar 
novas formas de explicar o fenômeno de interação museal. Assim, as pesquisas apontando para a importância da mediação semiótica e humana na aprendizagem em museus, por exemplo, aparecem e se fortalecem na Inglaterra (e. g., McManus, 1992; Hooper-Greenhill, 1999b), para posteriormente tomarem corpo nos Estados Unidos. Vale ressaltar a importância de outros países na construção desse campo de pesquisa. Canadá, França, Portugal, Espanha são países representativos da pesquisa educacional voltada para a aprendizagem e/ou para os museus.

É considerável o número de publicações na área, que pode ser observado pelos levantamentos bibliográficos realizados pelo Grupo para Educação em Museus (Group for Education in Museum), da Inglaterra, e pelo Projeto Colaborativo de Aprendizagem em Museus (Museum Learning Collaborative Project), atual UPCLOSE, nos Estados Unidos ${ }^{22}$. Mas, apesar da extensa literatura, muitas questões ainda estão colocadas sobre a aprendizagem nesses espaços:

- Museus virtuais - frente a enorme expansão das possibilidades de interação dos websites dos museus de ciências, não foram encontradas pesquisas dispostas a entender essa ferramenta no processo de aprendizagem dos webvisitantes. Poucas são as pesquisas sobre o uso de sistemas tecnológicos recentes em exposições, gerenciamento de coleções e informações ou comunicação entre pesquisadores da área (como em redes digitais de grupos de pesquisa). Em outras áreas (que não aprendizagem em museus), pesquisas sobre o uso dessas ferramentas na conservação de acervos são mais freqüentes. Acredita-se que esse seja um tema com forte tendência de expansão entre os museus e promete constituir-se como um campo importante de investigação. Vale ressaltar que o periódico Museum Management and Curatorship incluiu em seu editorial, em 2008, uma seção sobre Patrimônio Digital.

- Públicos especiais - com exceção de alguns trabalhos (e. g., BROOKE; SOLOMON, 2001), não foram encontradas pesquisas que procuram compreender o processo de aprendizagem desenvolvido por portadores de necessidades especiais em museus de ciências. Em um momento em que a Educação Inclusiva vem sendo debatida em diferentes esferas da sociedade e os museus colocam-se como importantes atores desse processo, é importante que atenção seja dada a como esses públicos interpretam as exposições e se engajam nas atividades educativas propostas pelos museus.

\footnotetext{
${ }^{22}$ www.gem.org.uk e www.upclose.lrdc.pitt.edu.
} 
- Unidade de análise - frente à variedade de referenciais teórico-metodológicos, seria importante compreender quais as unidades de análise, quais os elementos do processo de ensino-aprendizagem em museus que contribuiriam para um melhor entendimento do todo desse processo sistêmico. Não se trata de analisar somente uma parte (a unidade) para entender o todo, mas sim de analisar o todo por meio da unidade. Como sugere Giordan (2006, p.19 e 37), "a unidade, como um tipo de generalização, pode ser empregada como instrumento analítico para a compreensão do todo" e "por se referir às características e propriedades concretas do fenômeno, não perde as propriedades inerentes ao todo que devem ser objeto de explicação, mas trazem em si as formas primárias mais simples dessas propriedades que motivaram sua análise". A construção de um conhecimento sobre quais unidades de análise constituir-se-iam como inerentes aos processos de aprendizagem constitui-se em terreno fértil para futuras pesquisas.

- Função social dos museus - dentro da área de aprendizagem em museus, há um consenso de que a função educativa dos museus passa pelo processo ensino/aprendizagem, mesmo para aqueles que consideram que os visitantes vêm aos museus com sua motivação voltada para o lazer (mas acabam construindo significados independentemente de sua motivação inicial). Mas faltam as pesquisas (em museus de ciências) que reflitam sobre a aprendizagem enquanto elemento da construção da identidade do sujeito no meio social, ainda mais em relação à cultura científica. Como se dá a inserção do setor educativo na pesquisa e conservação do acervo de um museu de ciências? Como os museus de ciências têm permitido aos indivíduos, a partir de sua atividade principal de musealizar objetos e paisagens, novas leituras do mundo? Essas questões não foram abordadas na literatura analisada e poderiam ser pertinentes para o entendimento da "ação educativa" do museu como não limitada à extroversão do patrimônio.

As questões colocadas giram em torno não somente do fortalecimento de diretrizes teórico-metodológicas na área, mas também do entendimento de como os principais elementos envolvidos na aprendizagem influenciam a construção de significados durante e após as experiências museais, pelo indivíduo e pelo grupo social. Nesse sentido, estudos que analisem mais profundamente cada um dos diferentes fatores, mas que deem conta de interpretá-los em uma visão sistêmica, são importantes para o fortalecimento de um campo teórico sobre aprendizagem em museus. Faltam para isso, como coloca Falk (2004), escala e 
escopo nos modelos de pesquisa: olha-se para grupos ou indivíduos dentro de um espaço e tempo delimitados ao invés de se olhar para o que acontece quando o museu é considerado uma pequena parte dentro de um todo. Seriam necessárias, portanto, pesquisas mais verticais que deem conta da variedade de experiências que ocorrem nos museus e, também, mais horizontais, que compreendam essas experiências em conexões com a vida integral dos sujeitos.

\subsection{O MUSEU DE CIÊNCIAS COMO ESPAÇO DE APRENDIZAGEM}

O montante e o rigor das pesquisas apresentadas acima, por si, justificariam a consideração dos museus como espaços de aprendizagem ${ }^{23}$. Entretanto, poder-se-ia dizer que esse argumento não é válido, pois parte de premissas que poderiam ser falsas, já que o fato de haver pesquisas sobre o tema não garantiria que ocorresse aprendizagem em museus. Mesmo considerando que o pensamento indutivo nesse caso é evidentemente forte e que adições de premissas podem tornar o argumento ainda mais forte, serão trazidos, para os mais céticos, argumentos baseados na lógica dedutiva.

Quais as características, então, de um espaço de aprendizagem? Esses elementos podem ser atribuídos aos museus? Para responder a essas questões, a seleção de atributos que caracterizem um espaço de aprendizagem, bem como a reflexão sobre sua ocorrência nos museus, devem ser consideradas. Porém, frente às numerosas possibilidades de entendimento do termo aprendizagem, é necessário, inicialmente, um posicionamento sobre o conceito de aprendizagem considerado.

Em uma perspectiva histórico-cultural do desenvolvimento humano, com suas raízes no pensamento de Vigotski, a aprendizagem é uma forma particular de interação homem/mundo, que envolve sujeitos que se apropriam de aspectos culturais de forma consciente e ativa, tornando-se capazes de contribuir, cada vez mais, para o desenvolvimento social (DAVYDOV, 1988a,b, 1999a; LOMPSCHER; HEDEGAARD, 1999). Aprendizagem é, portanto, "um complexo processo de aquisição de experiências que levam a mudanças

\footnotetext{
${ }^{23}$ O termo "espaço" foi preferido a "local", em concordância com os argumentos expostos por Cedro (2004), que, baseado nas ideias de Certeau (1994 apud CEDRO 2004), vê o espaço como um lugar praticado. Enquanto o lugar é a ordem segundo a qual os elementos coexistem, é uma configuração instantânea de posições, o espaço constitui-se em movimento. Assim, a leitura é o espaço produzido pela prática do lugar escrito enquanto "a escola, o lugar socialmente destinado a educação, transforma-se em espaço por meio das ações da comunidade envolvida na atividade educativa" (CEDRO, 2004, p. 45).
} 
qualitativas e quantitativas nas estruturas e características psíquicas (assim como físicas) de um indivíduo" (LOMPSCHER; HEDEGAARD, 1999, p. 12, tradução nossa). Esses processos sempre estão presentes em um sistema de atividade, na interação do sujeito com o mundo, podendo somente fazer parte da atividade, de forma não-intencional, como nas atividades de jogar, conversar ou trabalhar, ou constituindo-se como uma atividade em si, a Atividade de Aprendizagem, dotada de intencionalidade (DAVYDOV, 1988b).

A primeira dimensão dada à aprendizagem, a de um processo geralmente não intencional presente no cotidiano, é mais fortemente observada no conceito de "aprendizagem situada”, proposto por Lave (1988). Para a autora, a aprendizagem também está imersa na atividade, no contexto e na cultura, sendo um processo social por meio do qual o conhecimento é co-construído. É geralmente não-intencional e pressupõe a interação social e a colaboração, constituindo-se como a característica central de um processo que junto com Ettiene Wenger, denominou de "participação periférica legitimada" (legitimate peripheral participation) (LAVE; WENGER, 1991). Esses autores, em seus estudos, sugerem que seja dada atenção ao fato de que

aprendizes inevitavelmente participam de comunidades de praticantes e que
o domínio do conhecimento e de habilidades requer que novos membros
busquem uma participação total nas práticas socioculturais de uma
comunidade. A participação periférica legitimada fornece um modo de falar
sobre recém-chegados e veteranos e sobre atividades, identidades, artefatos e
comunidades de conhecimento e de prática. Refere-se ao processo pelo qual
novos membros tornam-se parte de uma comunidade de prática (LAVE;
WENGER, 1991, p. 29).

Assim, a participação periférica legitimada é um termo usado para caracterizar o modo como um novato integra-se a uma comunidade de prática. Sua inserção inicialmente periférica transforma-se gradualmente, em um processo de aprendizagem coletiva, possibilitando sua legitimação como membro potencial. Evidências de aprendizagem neste modelo de participação em comunidades envolveriam, portanto, transformações na participação dos sujeitos em atividades socioculturais ao assumirem mais responsabilidades em determinada atividade.

Em estudos posteriores, um dos autores redimensiona o caráter não-intencional da aprendizagem (WENGER, 1999). Para ele, há, em cada uma das comunidades de prática, uma identidade definida por um interesse comum e um repertório compartilhado de recursos (experiências, relatos, ferramentas, rotinas, palavras, instrumentos, maneiras de fazer, gestos, símbolos, conceitos) produzidos ou adotados que fazem parte de suas práticas. Os novatos, ao 
adentrarem um uma comunidade de prática, engajam-se em um processo de aquisição desses recursos que pode ou não ser intencional: a aprendizagem pode ser a razão de a comunidade manter-se coesa ou o resultado acidental das interações dos membros.

Ao considerar que a aprendizagem pode ser a razão de uma comunidade manter-se unida, Wenger ressalta o caráter da intencionalidade do processo de ensino-aprendizagem e se aproxima daquilo que, como citado anteriormente, Davydov (1988b) distinguiu de aprendizagem: a atividade de aprendizagem.

Frente a essas possibilidades de definição conceitual e consequente estrutura de análise, nesse trabalho, a aprendizagem é assumida como o processo de articulação inter e intrapsíquica, com internalização e externalização do conhecimento humano historicamente construído que, ao ser realizado pelo sujeito, constitui a ele mesmo e, simultaneamente, à cultura humana. Já a atividade de aprendizagem é considerada como um tipo especial de atividade humana organizada para a otimização desse processo, ou seja, voltada para a reprodução pelos indivíduos do que foi produzido socialmente, visando o desenvolvimento psíquico.

Os lugares que possibilitem que o processo de aprendizagem seja posto em movimento, na perspectiva de Certeau (1994 apud CEDRO 2004), podem ser considerados espaços de aprendizagem. Os museus, ao constituírem-se como lugares da "realização da aprendizagem dos sujeitos orientado pela ação intencional de quem ensina" (cf. CEDRO, 2004, p. 45), com conhecimento humano historicamente construído representado por seus objetos/artefatos, em que a mediação (humana e semiótica) é processo fundamental, são, portanto, espaços de aprendizagem.

Assim, ao se considerar que os museus constituem-se como espaços de aprendizagem, assume-se que nesses locais ocorra não somente a aprendizagem mas também a possibilidade do desenvolvimento de atividades de aprendizagem. Tendo em vista o objeto desta pesquisa, o entendimento da visita aos museus como uma atividade de aprendizagem, faz-se necessária portanto uma melhor compreensão de como seria estruturada uma atividade de aprendizagem nos espaços museais. Para isso, antes de tudo, é necessário apresentar um breve histórico do conceito de atividade e uma aproximação da Teoria da Atividade, bem como os componentes presentes em uma atividade de aprendizagem. 
Capítulo 2

Teoria da Atividade e Atividade de Aprendizagem 



\section{TEORIA DA ATIVIDADE E ATIVIDADE DE APRENDIZAGEM}

A Teoria da Atividade é freqüentemente descrita como um dos resultados do esforço da Psicologia Soviética em formular uma nova psicologia baseada na filosofia marxista. Suas raízes são colocadas no século XIX, com os trabalhos de Kant, Hegel, Marx e Engels, mas é tida como fortalecida nos anos 20 e 30 do século seguinte (ROGERS; SCAIFE, 1997). Os nomes usualmente associados a esse desenvolvimento, como A. N. Leontiev, A. R. Luria e S. L. Rubinstein, enfatizaram a importância da atividade no desenvolvimento do psiquismo humano, já presente nas ideias de Vigotski (BANNON, 1997; ENGESTRÖM, 1999a; ROGERS; SCAIFE, 1997; WAITE, 2003). Mas como se deram essas transformações do conceito de atividade? Como se tornou uma categoria importante nas pesquisas em psicologia?

Historicamente, como aponta Kozulin (1986), o conceito de atividade teve e tem um importante e ambíguo papel na psicologia soviética assim como o tiveram o conceito de consciência na psicologia europeia do final do século XIX e o conceito de comportamento nos estudos americanos de meados do XX. Entretanto, para o autor, o fato do conceito de atividade ser considerado categoria chave nas pesquisas em psicologia tornou extremamente dificultosa sua definição mais consensual. Assim, a compreensão da "metamorfose" que esse conceito tem sofrido é crucial para o entendimento das convergências e divergências entre grupos e, portanto, devem ser vistas à luz de sua história ${ }^{24}$.

Introduzido na Psicologia Soviética por Vigotski, o conceito de atividade foi proposto como um princípio explanatório pertinente ao estudo da consciência humana, como uma tentativa de resolver teoricamente a tautologia então presente nos estudos psicológicos - a explicação do fenômeno da consciência por meio do conceito de consciência. Se a consciência tornou-se um objeto de estudo da psicologia, uma outra camada da realidade deveria, portanto, ser usada como princípio explanatório para a sua compreensão, que não o próprio conceito de consciência. Essa camada, esse novo princípio explanatório poderia ser a atividade desenvolvida socialmente (Kozulin, 1986).

\footnotetext{
Vale lembrar que, além das transformações que o conceito sofre ao longo do tempo, os leitores em línguas que não a russa devem ter em mente que as traduções e as diferenças culturais entre os contextos de origem e traduções propiciam variações não somente sintáticas mas, principalmente, semânticas. Para uma reflexão sobre a "perda teórica" gerada nesse processo, em relação ao conceito de "Atividade", veja CEDRO (2008).
} 
No artigo "A Consciência como Problema da Psicologia do Comportamento", Vygotsky $(1979)^{25}$, frente às diferentes abordagens de pesquisa de seus contemporâneos adeptos do estudo da consciência ou do comportamento, traz a perspectiva de que a primeira é um problema da estrutura do segundo e é construída na relação com outros sujeitos. Nessa visão, tentou unir um ramo da psicologia com características de "ciência mental", que descrevia as propriedades dos processos psicológicos superiores, a outro, com características de "ciência natural" preocupada com os processos elementares sensoriais e reflexos. Compreendendo essa aproximação à luz da teoria marxista da história da sociedade, Vigotski estabeleceu premissas para uma teoria unificada do comportamento e da mente, dando um papel central ao conceito de atividade enquanto um princípio explanatório (KOZULIN, 1986).

Além do contexto teórico-metodológico da psicologia na época, as filosofias marxista e hegeliana também se constituíram como instrumental para o desenvolvimento do conceito de atividade para Vigotski. Segundo Kozulin (1986, p. 266, tradução nossa), Vigotski encontrou nesses autores uma teoria social para a atividade humana, em oposição ao naturalismo e à receptividade passiva da tradição empirista:

De acordo com Vygotsky, o comportamento humano e a mente podem ser considerados mais em termos de ações intencionais e significativas, do que como reações biológicas, adaptativas. Objetos da experiência humana - e, portanto, objetos em experimentos psicológicos - são elementos socialmente e culturalmente significativos e não somente estímulos abstratos. [A] Atividade então toma o lugar do hífen na fórmula $S-R$, transformando-a na fórmula objeto - atividade - sujeito, em que tanto objeto como sujeito são historicamente e culturalmente especificados.

Assim, a emergência da consciência é vista como um fenômeno historicamente situado e ligado à atividade produtiva do homem. Ao agir sobre a natureza, o homem pode transformá-la com meios criados para isso e, nesse movimento, distancia-se e faz dela objeto de sua ação. Ao se distanciar, emerge a consciência, que é ao mesmo tempo causa e efeito da ação humana. Entretanto, ao agir sobre a natureza, o homem não perde sua condição de ser da natureza, sendo possível argumentar, como coloca Pino (2005, p. 17), que "nele, a natureza se transforma a si mesma." Novamente, ao localizar a consciência como causa e efeito da ação humana, Vigotski fortalece a possibilidade da atividade constituir-se como um princípio para explicar a consciência que não por ela mesma.

Entretanto, o início dos anos 1930 foi marcado pela extrema presença do governo soviético nas esferas sociais, não escapando o campo científico. Pesquisadores da psicologia

25 Publicado pela primeira vez em 1925. 
que adotassem abordagens antimarxistas, como a psicanálise, não eram bem-vindos ao meio acadêmico. Muitos alteraram suas linhas de pesquisa e alguns se deslocaram para outros países. Vigotski continuou em Moscou, mas um grupo de alunos seus, incluindo Leontiev, Zaporozhets e Bozhovich, estabeleceu, na cidade ucraniana de Kharkov, um programa de pesquisa experimental em Psicologia do Desenvolvimento (KOZULIN, 1986).

Para Kozulin (1986) e Daniels (2003), foi o grupo Kharkov de psicólogos liderados por Leontiev que desenvolveu o que hoje é compreendido por Teoria da Atividade.

\section{1 TEORIA DA ATIVIDADE}

Hoje, a Teoria da Atividade corresponde a um nome comumente aceito, não somente na Rússia mas em diversos outros países, para uma linha de teorização e pesquisa ligada às práticas culturais que procura explicá-las baseando-se nos contextos de desenvolvimento dos indivíduos em relação à sua história e à sua cultura (ENGESTRÖM; MIETTINEN, 1999). Nessa perspectiva, o comportamento de uma pessoa é parte de um contexto que é maior que o próprio indivíduo. A mente humana vem a existir, desenvolver-se e ser entendida em um contexto de significação e de interação socialmente determinada entre seres humanos e o ambiente material, planejada em função de objetivos e com o uso de artefatos. Para Davydov (1999b), a atividade existe em forma coletiva e individual quando uma pessoa atua como um ser social genérico. Nessa visão, ao mesmo tempo em que a vida individual de um ser humano pode ser uma manifestação mais específica ou mais universal de uma vida humana genérica, o caráter universal da atividade pode estar representado em um único indivíduo.

A atividade é considerada como parte essencial e indivisível da vida social e inclui objetivos não somente físicos, mas também mentais. Portanto, não é uma entidade isolada. Há um agente, um sujeito que atua individual ou coletivamente e direciona sua atividade a algo. Há objetos com as quais o sujeito interage e é a atividade que medeia essa interação (BANNON, 1997). O uso de instrumentos nessa interação confere uma qualidade produtora à ação humana, capaz de transformar, ao mesmo tempo, o sujeito e o objeto. A atividade humana é, portanto, considerada como social, instrumental e transformadora do real (PINO, 2001).

Claramente, essas ideias estão bastante relacionadas às colocadas por Vigotski, em que a ação orientada ao objeto é mediada tanto por instrumentos materiais como por ferramentas psicológicas. Entretanto, para Engeström e Miettinem (1999), a mediação por outros seres 
humanos e por relações sociais não é explicitada teoricamente no modelo triangular de ação (S - X - R). Tal integração, segundo o autor, demandou um apuramento no conceito de atividade pela distinção entre atividade coletiva e ação individual. Essa distinção foi realizada por Leontiev $\left(2004^{26}\right)$ que evidenciou a divisão de trabalho em uma atividade e fortaleceu a relação entre o motivo e o objeto da atividade. A Leontiev, portanto, é creditada a sistematização do conceito de Atividade, aceito como o "aspecto central do processo de humanização e do desenvolvimento do psiquismo" e a "unidade básica para a compreensão do mesmo" (MIGUEIS; MOURA; PORTUGAL, 2009, p. 04).

O exemplo clássico elaborado por Leontiev (2004, p. 82) para exemplificar uma atividade coletiva, com distinção entre ação e atividade e motivos relacionados a objetos, refere-se a uma caçada:

Quando um membro de uma coletividade realiza a atividade de trabalho, realiza-a também com o fim de satisfazer uma necessidade sua. Assim, a atividade do batedor que participa na caçada coletiva primitiva é estimulada pela necessidade de se alimentar ou talvez de se vestir com a pele do animal. Mas para que está diretamente orientada sua atividade? Pode ser, por exemplo, assustar a caça e orientá-la na direção de outros caçadores que estão à espreita. É propriamente isso que deve ser o resultado da atividade do caçador. Ela pára aí, os outros caçadores fazem o resto. É evidente que esse resultado (assustar a caça) não acarreta por si mesmo e não poderia acarretar a satisfação da necessidade de alimento, de vestuário etc., que o batedor sente. Assim, aquilo para o que estão orientados os seus processos de atividade não coincide com o seu motivo; os dois são separados. Chamaremos ações aos processos em que o objeto e o motivo não coincidem. Podemos dizer, por exemplo, que a caçada é a atividade do batedor, e o fato de levantar a caça é a sua ação.

E continua, ressaltando a divisão de trabalho na coletividade:

Como pode nascer uma ação, isto é, a separação do objeto da atividade e do seu motivo? Visivelmente a ação só é possível no seio de um processo coletivo agindo sobre a natureza. $\mathrm{O}$ produto do processo global, que responde a uma necessidade da coletividade, acarreta igualmente a satisfação da necessidade que experimenta um indivíduo particular, se bem que ele possa não efetuar as operações finais (o ataque direto ao animal e sua matança, por exemplo) que conduzem diretamente à posse do objeto desta necessidade. Geneticamente (isto é, pela sua origem), a separação entre o motivo e o objeto da atividade individual é o resultado do parcelamento em diferentes operações de uma atividade complexa, inicialmente "polifásica", mas não única. Essas diversas operações, absorvendo doravante todo o conteúdo de uma dada atividade do indivíduo, transforma-se para ele em ações independentes, continuando bem entendido a não ser senão um só dos numerosos elos do processo global do trabalho coletivo (LEONTIEV, 2004, p. 83).

26 Publicado pela primeira vez em 1959. 
Esta distinção entre atividade, ação e operação pode ser considerada a base para o modelo hierárquico da atividade proposto por Leontiev (2004). Para ele, há uma distinção entre esses elementos da seguinte forma:

Nem todo processo é uma atividade. Nós designamos apenas por este termo os processos que, realizando tal ou tal relação do homem com o mundo, respondem a uma necessidade particular que lhes é própria. Assim, os processos de memorização não são, propriamente falando, uma atividade, pois não realizam, regra geral, qualquer relação autônoma com o mundo e não respondem a qualquer exigência particular.

Designamos pelo termo atividade os processos que são psicologicamente determinados pelo fato de aquilo para que tendem no seu conjunto (o seu objeto) coincidir sempre com o elemento objetivo que incita o paciente a uma dada atividade, isto é, com o motivo (LEONTIEV, 2004, p. 315).

Assim, o fator desencadeador da atividade é a necessidade: ela motiva o sujeito a desenvolver objetivos e a agir para satisfazê-la. Apesar de ser condição da atividade, a necessidade não pode determinar a sua orientação concreta,

pois é apenas no objeto da atividade que ela encontra a sua determinação: deve, por assim dizer, encontrar-se nele. Uma vez que a necessidade encontra a sua determinação no objeto (se 'objetiva' nele), o dito objeto torna-se motivo da atividade, aquilo que o estimula (LEONTIEV, 2004, p. $115)$.

As ações relacionam-se com a atividade, na medida em que pertencem a ela, e uma atividade constitui-se em um conjunto de ações, sem se constituir como uma somatória delas. No entanto, enquanto a atividade é vinculada a um motivo, tal fato não acontece com as ações. "Uma ação é um processo cujo motivo não coincide com o seu objeto (isto é, com aquilo que visa), pois pertence à atividade em que entra a ação considerada" (LEONTIEV, 2004, p. 316).

Um exemplo possível que ocorre frequentemente em museus de ciências refere-se às visitas de escolares. É possível imaginar um grupo de estudantes que visita o museu inserido em uma atividade de ensino proposta por seu professor, em que todos deverão entregar um relatório pós-visita. Pode-se dizer que estão todos em uma atividade de visita? Não é simples responder a essa questão sem um entendimento do que essa visita representa para cada indivíduo. Se o professor avisa à turma que não irá mais pedir um relatório e que a visita é opcional, podem ser observadas algumas posições: um aluno não fará a visita, outro irá sem fazer o relatório e outro irá e produzirá um texto representativo daquilo que vivenciou no museu de ciências. Nos dois últimos casos, fica claro que aquilo para o que se direciona a 
visita, isto é, o discurso expositivo do museu (cf. MARANDINO, 2001), era o que incitava os estudantes a participarem da visita. Assim, a apropriação do conteúdo do museu satisfazia a necessidade desses estudantes de conhecer outros lugares, saber sobre assuntos diferentes e/ou se divertir em novos ambientes. É possível dizer que esses alunos estariam em atividade de visita se fossem ao museu. Para o estudante que desistiu da visita, é provável que o motivo que o levaria à instituição seria a nota dada a seu relatório e não o conteúdo do museu. Nesse caso, a atividade não seria a visita em si, mas sim a preparação do relatório. A visita ao museu constituir-se-ia então como uma das ações para o estudante conseguir a nota desejada. É possível supor que a visita possa ser considerada importante para este estudante, ela pode ter um "motivo apenas compreendido", mas o "motivo realmente eficaz" (LEONTIEV, 2004, p. 318) é a obtenção de uma boa nota no relatório. Entretanto, caso esse estudante realizasse a visita, o ambiente do museu poderia lhe interessar e mobilizar sua ação com outra significação: o motivo da visita deslocar-se-ia da obtenção da nota e passaria a ser a apropriação do conteúdo do museu.

Um outro elemento da estrutura da atividade é a operação. A operação é entendida como o modo pelo qual a ação é desenvolvida. Embora seja conteúdo indispensável de toda a ação, não se identifica com a mesma, pois “uma só e mesma ação pode realizar-se por meio de operações diferentes, e inversamente, ações diferentes podem ser realizadas pelas mesmas operações.” (LEONTIEV, 2004, p. 323). Isso ocorre porque, enquanto as ações são determinadas por um fim, as operações dependem das condições em que é dado este fim. Assim, um visitante que deseja interagir com um conteúdo de um museu de ciências precisa ler a legenda ou o infográfico relacionados a um aparato para entender os mecanismos de interação física utilizáveis. Nesse caso, há modos de execução diferentes, ou seja, operações diferentes (leitura de legenda e leitura de infográfico) para uma mesma ação (a interação física com o aparato).

Considerando-se as operações conscientes, percebe-se que elas se formam primeiramente como ações, como processos que visam um fim, que podem, em seguida, “adquirir a forma de práticas automizadas" (LEONTIEV, 2004, p. 323). Mas

como é que uma ação se transforma em operação e, por conseqüência, em habilidade e em hábito? Para transformar a ação de uma criança em operação devemos dar-lhe um fim novo no qual a ação considerada se torne um meio de execução de uma outra ação. Por outras palavras, o que era o fim da primeira ação deve transformar-se numa das condições da ação requerida pelo novo fim (LEONTIEV, 2004, p. 323). 
No caso do visitante que interage fisicamente com o aparato, a leitura, em um momento anterior da sua vida, constituiu-se como uma ação mental, mas, agora, apresenta-se como uma prática suficientemente elaborada e automizada (mas que estará disponível à consciência em uma situação-problema). Transformada em operação, a leitura agora é uma condição da nova ação, a interação física com o aparato.

Percebe-se assim que essa relação entre atividade-ação-operação não é fixa. Uma ação, por exemplo, pode se transformar em atividade "quando passa a ter para o sujeito um motivo em si (SFORNI, 2004, p. 99)". Vê-se, nesse caso, uma relação particular entre atividade e ação, em que o motivo, ao se deslocar, permite a transformação da ação em atividade. "É desta maneira, com efeito, que nascem novas atividades" (LEONTIEV, 2004, p. 317), embora somente “'motivos compreensíveis' tornam-se 'motivos eficazes' em certas condições, e é assim que os novos motivos surgem, e por conseguinte novos tipos de atividades" (LEONTIEV, 2004, p. 70).

Dessa forma, as atividades distinguem-se umas das outras por seu motivo, ou seja, por seu objeto. O motivo tem papel fundamental na estrutura da atividade pois é ele que regula a atividade do sujeito e, "este, movido pelo motivo, desenvolve ações, que se subordinam aos objetivos conscientes e desenvolve, também, operações consideradas como o modo de execução de uma ação" (MIGUEIS; MOURA; PORTUGAL, 2009). As relações estabelecidas entre necessidades, objetivos, motivos, condições, atividade, ações e operações pode ser representada na figura abaixo (Figura 1).

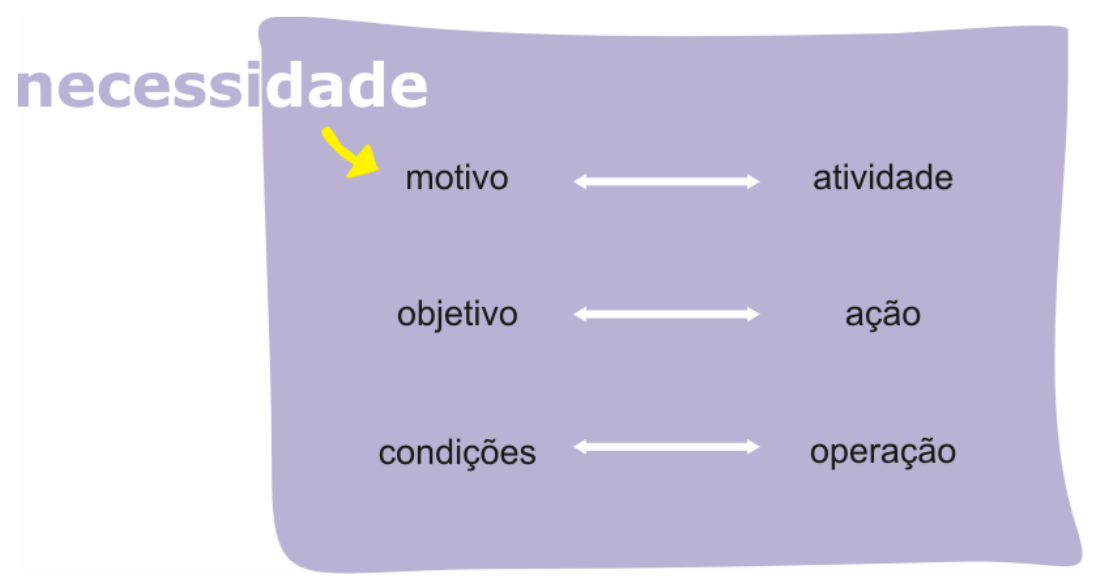

Figura 1 - Níveis hierárquicos da atividade, segundo Leontiev (2004). 
As ideias sobre a fluidez entre os diferentes níveis hierárquicos e a presença de metas individuais e globais presentes nos estudos de Leontiev foram continuadas nos estudos de Engeström (p. e., 1987, 1999a,b, 2001), que organizou a atividade em regras e estruturas do mundo social (DANIELS, 2003). Yrjö Engeström, pesquisador do "Center for Activity Theory and Developmental Work Research", na Finlândia, ressalta que as ações individuais ou coletivas serão compreendidas quando interpretadas à luz de sistemas de atividades inteiros e considera que estes sistemas constituem-se como as unidades de análise para pesquisas da área. Ao pensar na atividade como um sistema de atividade, Engeström preteriu o nível micro da análise, focado no ator, no agente social, ao nível macro, centrado no coletivo, na comunidade. Nesse sentido, as análises dos sistemas de atividade, expandidas a instituições ou movimentos, exigiriam a compreensão de que as atividades relacionadas desdobram-se por longos períodos de tempo (ENGESTRÖM, 1987, 2001).

Esses sistemas de atividade, conforme Engeström (1999a), incluem, além do objeto, do sujeito e dos artefatos mediadores (simbólicos ou materiais), as regras, as comunidades e a divisão de trabalho, relacionados dinamicamente entre si (Figura 2).

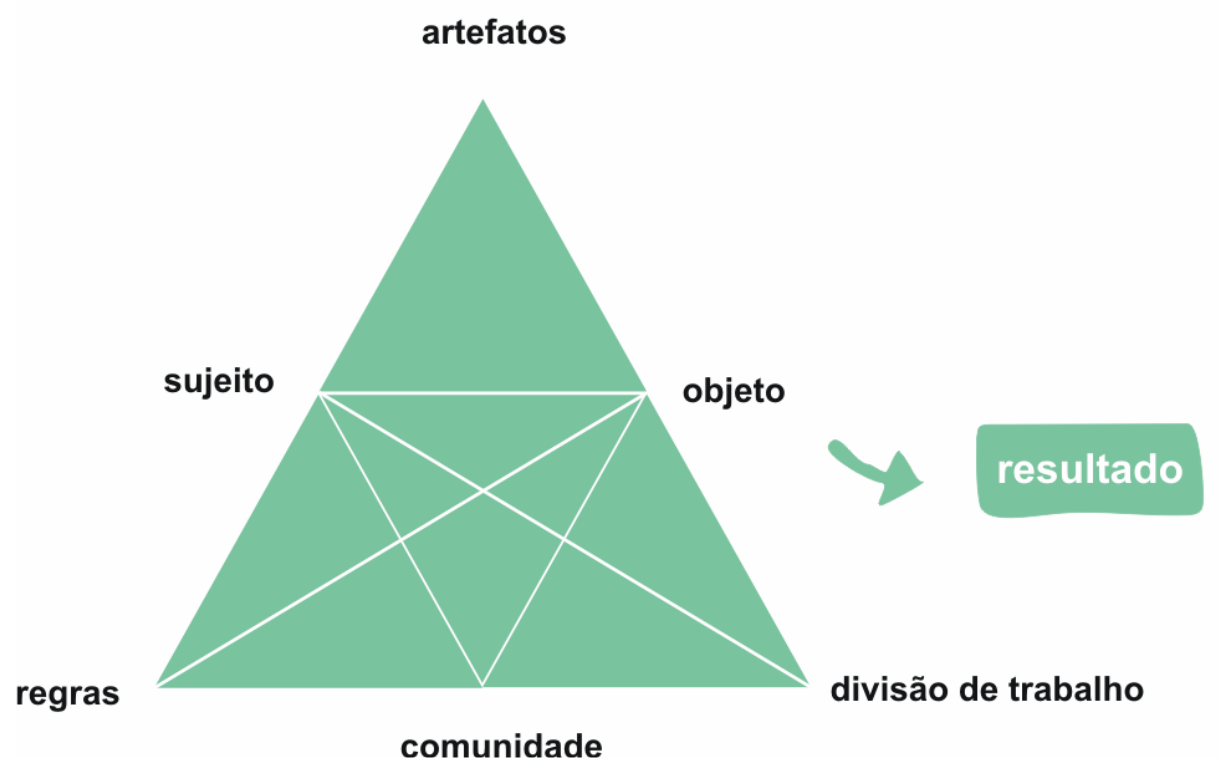

Figura 2 - Modelo de um sistema de atividade (ENGESTRÖM, 1999a). 
A divisão de trabalho em um sistema de atividade gera diferentes pontos de vista, pois os participantes possuem diferentes histórias de vida, tradições e interesses. Além disso, os próprios sistemas de atividade carregam, em seus artefatos, sujeitos e regras, vozes datadas de diferentes momentos. A multivocalidade, vista histórica e localmente, também é fonte de tensões que exigem tradução e inovação. E são as tensões e contradições presentes nesses sistemas, acentuadas pelas transformações contínuas dos elementos constituintes do sistema e entre seus diferentes níveis hierárquicos (atividade, ação, operação), a força motriz para a mudança e o desenvolvimento.

Essas contradições não equivalem a problemas ou conflitos. São tensões acumuladas historicamente, em um sistema de atividades ou entre eles, que podem gerar conflitos ou renovar possibilidades de mudança da atividade. Uma "reorquestracão" das diferentes vozes, dos diferentes pontos de vista, sob uma perspectiva histórica, faz-se então necessária para se identificar os ciclos passados de um sistema de atividade (DANIELS, 2003). Para a reorganização de uma nova estrutura desse sistema, é preciso uma análise reflexiva das estruturas anteriores e uma apropriação, uma internalização, de modelos e ferramentas avançadas para resolver as contradições internas. Na medida em que o processo de internalização estimula a auto-reflexão, cresce também a busca por soluções para essas contradições e, conseqüentemente, o processo de exteriorização torna-se cada vez mais importante.

Quando um novo modelo de atividade é implantado, a exteriorização atinge seu pico. Com a estabilização desse novo modelo, a internalização de novos significados começa novamente (ENGESTRÖM, 1999a). Engeström denominou essa construção de uma nova estrutura a partir de uma precedente como ciclos expansivos dos sistemas de atividade (Figura 3). Para o autor, os ciclos de expansão que ocorrem no nível dos sistemas de atividade coletiva correspondem, no nível individual, à zona de desenvolvimento imediato proposta por Vigotski (2007). 


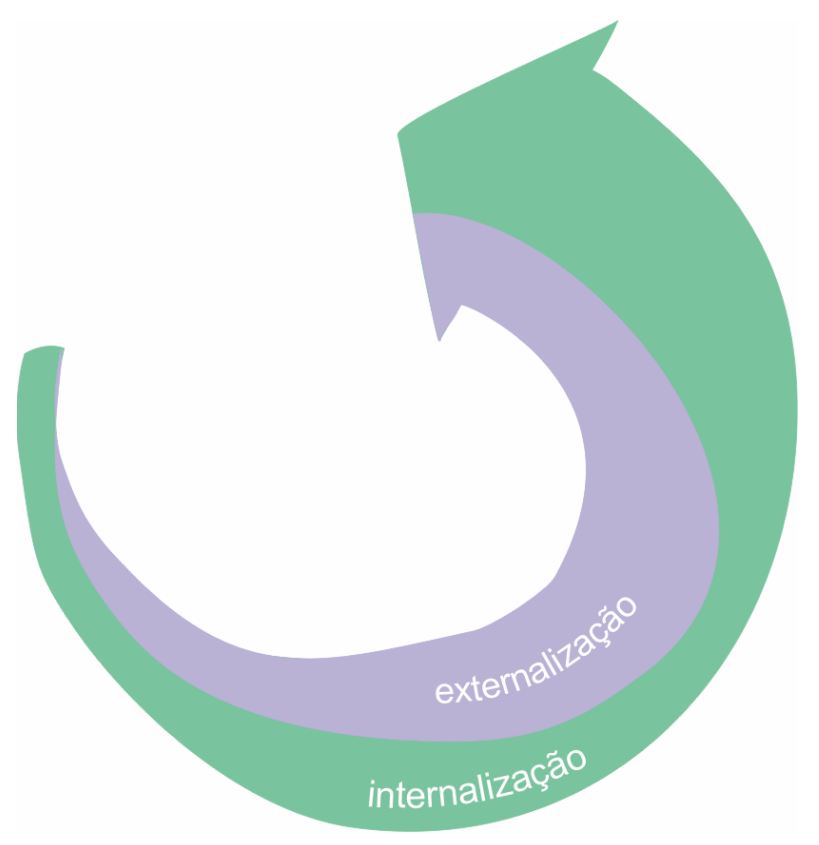

Figura 3 - Ciclos expansivos, com processos de internalização e externalização (ENGESTRÖM, 1999a).

Essa imagem dos ciclos expansivos pode ajudar na compreensão das atividades de ensino e aprendizagem presentes em museus de ciências. Se, como afirma Engeström (1999a), um ciclo de transformação expansiva pode ser compreendido como uma jornada coletiva pela zona de desenvolvimento imediato da atividade, é possível imaginar a necessidade de analisar as tensões e as contradições internas desse sistema para reorganizar sua estrutura e buscar uma maior aproximação entre os motivos de um grupo de visitantes e os da equipe do museu para realizar atividades de ensino/aprendizagem. Mas, para uma análise mais cuidadosa das tensões e contradições em fluxo nessas atividades, é necessário primeiro identificar o que é considerado nesse trabalho como uma atividade de aprendizagem.

\subsection{TEORIA DA ATIVIDADE, ATIVIDADE DE APRENDIZAGEM E ATIVIDADE DE ENSINO}

Vale então retomar a distinção colocada anteriormente entre aprendizagem e atividade de aprendizagem. Os pesquisadores europeus em psicologia e aprendizagem Lompscher e Hedegaard (1999), baseados nos pressupostos de Leontiev, reiteram a necessidade de se diferenciar esses dois conceitos. Para eles, a aprendizagem é um processo que ocorre continuamente na vida das pessoas, ou melhor, 
é um conjunto de diferentes processos de aquisição de experiências que leva a mudanças quantitativas e qualitativas nas estruturas e características psíquicas (bem como físicas) de um indivíduo. Esses processos necessariamente se dão na estrutura da atividade, ou seja, na interação com o mundo (LOMPSCHER; HEDEGAARD, 1999, p.12, tradução nossa).

A aprendizagem ocorre, portanto, de forma não intencional, não objetivada especificamente para o desenvolvimento psíquico, mas como integrante de uma outra atividade, como o jogo, a comunicação cotidiana ou o trabalho.

Já a atividade de aprendizagem é

um tipo especial de atividade voltada para a aquisições de conhecimentos e habilidades sociais, por meio de suas re-produções pelo indivíduo, mediante ações de aprendizagem especiais sobre os objetos de aprendizagem (métodos e conhecimentos sobre o assunto) (LOMPSCHER; HEDEGAARD, 1999, p.12, tradução nossa).

Enquanto atividade, a aprendizagem ocorre não somente como uma função de eventos e situações imediatas, de forma menos ou mais acidental, mas principalmente como baseada em um sistema e uma lógica representativos de diferentes domínios das experiências e atividades sociais. Somente na atividade de aprendizagem ocorre o objetivo de aprender, enquanto em outras atividades, a aprendizagem passa a ser um produto derivado. Essas ideias estão totalmente ancoradas na compreensão da aprendizagem enquanto atividade de Davydov (1988a, b, 1999a), Davídov (1988) e Davídov e Márkova (1987).

$\mathrm{O}$ conceito de atividade de aprendizagem nessa perspectiva representa o enfoque teórico comum às pesquisas realizadas por mais de 20 anos em um amplo experimento soviético psicopedagógico de reestruturação dos programas escolares (DAVÍDOV; MÁRKOVA, 1987). Esse conceito formou-se a partir de um dos princípios dialéticomaterialistas fundamentais da psicologia soviética: o princípio de unidade entre a consciência e a atividade, no contexto da teoria da atividade. Assim, enquanto atividade, apresenta as características mencionadas na seção anterior (resumidamente: transformação do mundo pelo homem, estruturada entre atividade/ação/operação, com motivos, objetivos e condições relacionados a um resultado, regulada por tensões e contradições internas e modelada historicamente).

Entretanto, além dos atributos do conceito geral de atividade, a atividade de aprendizagem possui, conforme Davydov (1999a) a apresenta, um conteúdo específico relacionado ao objeto (que a faz diferir de qualquer outra atividade humana) e necessariamente envolve aspectos criativos ou transformadores. Surgem então as questões: o 
que é esse conteúdo específico da atividade de aprendizagem? O que faz dela um tipo particular de atividade humana?

A atividade de aprendizagem, diferentemente de outras atividades, é dirigida para a modificação e o desenvolvimento do aprendiz. Ao se relacionar ativamente com determinado conteúdo, ele pode adquirir habilidades e conhecimentos e re-produzir o que a sociedade produziu historicamente. Essa reprodução não é simplesmente uma cópia dos elementos culturais, mas sim sua re-elaboração pelo indivíduo, contextualizados em uma atividade específica. Diferentemente de outras atividades que promovem a transformação do mundo pelo sujeito, a atividade de aprendizagem tem como significação a transformação do próprio sujeito.

Alguns conceitos tornam-se relevantes nessa abordagem e necessitam de atenção. As correlações entre assimilação, desenvolvimento psíquico e ensino foram ressaltadas por Davídov e Márkova (1987), que procuraram abordá-los distintamente, mas também intrinsecamente. Para eles,

assimilação é o processo de reprodução, pelo indivíduo, dos procedimentos historicamente formados de transformação dos objetos da realidade circundante, dos tipos de relações entre eles e o processo de conversão desses padrões, socialmente elaborados, em formas da "subjetividade" individual. $O$ desenvolvimento se realiza por meio da assimilação (apropriação) pelo indivíduo da experiência histórico-social (DAVÍDOV; MÁRKOVA, 1987, p. 321, tradução nossa).

A assimilação, portanto, pode promover o desenvolvimento que se caracteriza "pelos avanços qualitativos no nível e nas formas das capacidades, dos tipos de atividade, etc., de que se apropria o indivíduo" (DAVÍDOV; MÁRKOVA, 1987, p. 322, tradução nossa). Nesse sentido, não é possível compreender o desenvolvimento como contraposto à apropriação, como processos independentes entre si, ou ainda como processos autônomos que ocorrem conjuntamente. Ao mesmo tempo, a apropriação nem sempre conduz ao desenvolvimento, pois um indivíduo pode dominar conhecimentos e habilidades, mas não dominar as capacidades, as formas gerais da atividade psíquica. Por isso, "alguns psicólogos, com toda justiça, diferenciam o efeito de assimilação de alguns conceitos e habilidades e o efeito do desenvolvimento", mas aceitam que "os avanços no desenvolvimento psíquico, por sua vez, servem de premissa para a assimilação de novos conhecimentos e habilidades de conteúdo mais complexo" (DAVÍDOV; MÁRKOVA, 1987, p. 323, tradução nossa). 
Baseados em Elkonin (1961) ${ }^{27}$, Davídov e Márkova (1987) afirmam que a atividade de aprendizagem é aquela cujo produto principal é a transformação do indivíduo, uma autotransformação, e nisso consiste sua principal particularidade. Assim, “o conteúdo principal da atividade de aprendizagem é a assimilação dos procedimentos generalizados de ação na esfera dos conceitos científicos e as mudanças no desenvolvimento psíquico da criança, que ocorrem sobre esta base" (DAVÍDOV; MÁRKOVA, 1987, p. 324, tradução nossa). Isso porque, no processo da atividade de aprendizagem, que é a atividade principal do período escolar do indivíduo, a criança não se apropria, não reproduz apenas conhecimentos e habilidades, mas, principalmente, as capacidades surgidas historicamente que subsidiam a consciência e o pensamento teóricos, ou seja, "a reflexão, a análise e o plano interior de ações" (DAVYDOV, 1988b, p. 4, tradução nossa).

O ensino passa a ter, assim, importância evidente no desenvolvimento dos indivíduos, ao se apresentar como um sistema de organização dos meios pelos quais o indivíduo tem acesso à experiência socialmente elaborada, bem como dos processos de apropriação. A escola é, tradicionalmente, o espaço destinado à organização do ensino e responsável por uma das transições cruciais na vida dos indivíduos: ao entrar na escola, "a criança começa a assimilar o ABC das formas mais desenvolvidas da consciência social - da ciência, da arte, da moralidade e do direito - as quais levam à consciência e ao pensamento teóricos" (DAVYDOV, 1998b, p. 3, tradução e grifo nossos). Assim,

os conhecimentos de uma pessoa e suas ações mentais (abstração, generalização etc.) formam uma unidade. "O conhecimento [...] não surge dissociado da atividade cognitiva do sujeito e não existe sem referência a ela",28. É legítimo, portanto, considerar o conhecimento, por um lado, como o resultado das ações mentais que, por definição, abrangem o conhecimento e, por outro, como o processo pelo qual esse resultado é alcançado e que reflete o funcionamento das ações mentais. Consequentemente, é totalmente aceitável usar o termo "conhecimento" para designar tanto o resultado do pensamento (o reflexo da realidade), como o processo pelo qual se obtém esse resultado (isto é, as ações mentais). "Todo conceito científico é tanto uma construção do pensamento como um reflexo do ser" ${ }^{\prime 29}$. Deste ponto de vista, um conceito é, ao mesmo tempo, um reflexo do ser e uma instrumentalidade da operação mental (1988b, p. 21, tradução nossa).

Vê-se, claramente, a estreita relação entre conhecimento e conceito e, mais especificamente, entre conhecimento teórico e conceito teórico e sua importância para o

\footnotetext{
${ }^{27}$ Elkonin, D. Problemas psicológicos de formación de la actividad de estudio de los escolares de menor edad. - Cuestones de psicologia de la enseñanza y la educación. Kiev, 1961. p. 12-13.

28 RUBINSHTEIN, L. Bytie i soznaine [Being and consciousness], p. 45. s/ data.

${ }^{29}$ Idem, p. 47.
} 
desenvolvimento psíquico. Como coloca Rubtsov (1996), a Psicologia moderna e a Didática diferenciam dois tipos de conhecimento, o empírico e o teórico, que correspondem, por sua vez, a dois tipos de pensamento, igualmente empírico e teórico. Dessa forma, os indivíduos podem abordar a realidade de duas maneiras bem distintas. A partir dos resultados obtidos por Davidov em suas pesquisas, Rubtsov (1996) compara esses dois saberes (Tabela 2):

Tabela 2 - Características principais dos conhecimentos teórico e empírico extraídas de Rubtsov (1996).

\begin{tabular}{ll}
\hline \multicolumn{1}{c}{ Conhecimento empírico } & \multicolumn{1}{c}{ Conhecimento teórico } \\
\hline $\begin{array}{l}\text { Elaborado quando se compara os objetos às } \\
\text { suas representações }\end{array}$ & $\begin{array}{l}\text { Elaborado quando se analisa relações entre as } \\
\text { coisas no interior de um sistema }\end{array}$ \\
\hline $\begin{array}{l}\text { Permite generalização formal das propriedades } \\
\text { dos objetos e consequente classificação, } \\
\text { independentemente dos laços entre objetos }\end{array}$ & $\begin{array}{l}\text { Permite conhecimento de tipo de relação entre } \\
\text { classes que caracteriza um representante de uma } \\
\text { classe e, ainda, um objeto em particular - relação } \\
\text { é apresentada como universal }\end{array}$ \\
\hline $\begin{array}{l}\text { Baseia-se na observação. Reflete propriedades } \\
\text { externas dos objetos. Apoia-se nas } \\
\text { representações concretas }\end{array}$ & $\begin{array}{l}\text { Reflete relações entre propriedades do objeto e } \\
\text { suas ligações internas. Supera representações } \\
\text { sensoriais }\end{array}$ \\
\hline $\begin{array}{l}\text { Constrói propriedade formal comum, análoga às } \\
\text { propriedades específicas dos objetos }\end{array}$ & $\begin{array}{l}\text { Determina ligação de uma manifestação geral } \\
\text { com suas manifestações concretas - elo entre } \\
\text { geral e particular }\end{array}$ \\
\hline $\begin{array}{l}\text { Concretiza-se pela escolha de exemplos relativos } \\
\text { a uma certa classe formal }\end{array}$ & $\begin{array}{l}\text { Concretiza-se pela transformação do saber em } \\
\text { teoria deduzida e pela explicação das } \\
\text { manifestações concretas do sistema }\end{array}$ \\
\hline Expresso e fixado por uma palavra, por um termo & $\begin{array}{l}\text { Expresso por diferentes modos de atividade } \\
\text { intelectual e, posteriormente, por diferentes } \\
\text { sistemas semióticos }\end{array}$ \\
\hline
\end{tabular}

Observa-se que, nessas possibilidades de se abordar a realidade, o processo de generalização tem sua importância, ao mesmo tempo, geral e particular: se, por um lado, ele é imprescindível nos dois tipos de conhecimento, por outro, toma caminho distintos em cada um dos processos. Esse conceito foi bastante estudado por Davídov (1982) e seus colegas que, ao investigarem o emprego do termo em materiais didáticos soviéticos, observaram sua associação, na maioria dos casos, à tomada de consciência pelo sujeito de alguns atributos comuns entre objetos comparados. Em suas palavras, o processo de generalização mais comumente encontrado nesses materiais relaciona-se ao trânsito, operado pelo sujeito, "da descrição de propriedades de um objeto individualizado ao seu encontro e separação em toda uma classe de objetos similares" (DAVÍDOV, 1982, p. 13, tradução nossa), com a identificação dos atributos estáveis repetidos em todos eles. Assim, relatam o predomínio da 
generalização empírica nas práticas educativas tradicionais: busca-se uma palavra que represente os atributos estáveis e, a seguir, procura-se identificá-los em novos objetos.

É possível imaginar, por exemplo, uma vitrina de um museu de história natural em que vários animais taxidermizados, como uma onça, um lobo-guará, um cateto e um furão, encontram-se expograficamente organizados sob a legenda 'Mamíferos'. Ao visitante, é possível analisar suas características externas, comparando entre si os animais ali expostos e buscando abstrair os atributos que são gerais, como presença de pelos ou quatro patas, e desconsiderando o que é variável, como o padrão de colorido ou o tamanho. Ao identificar um atributo geral, invariável, baseado nas características externas do objeto, por exemplo 'animal com pelos', por meio de um signo (um termo, um gráfico, etc.), o visitante realizou um processo de abstração. Esse movimento, a separação de 'animal com pelos', aliado a outros traços abstrato-genéricos observados (p. e., 'quatro patas'), leva à constituição do conceito abstrato/empírico 'mamífero'. Assim, o movimento da percepção para o conceito constitui a transição do concreto, sensorial, para o abstrato, imaginável (Davídov, 1982).

É passo fundamental da generalização, portanto, o processo de abstração ("processo abstrativo"), o "desprendimento mental de uns atributos dos objetos e o fenômeno de abstraílos em relação a quaisquer outros" (Davídov, 1982, p. 47, tradução nossa). Nessa separação, o sujeito identifica o que é essencial, invariável - aquilo que leva ao conceito abstrato, e descarta o que é secundário. Como no processo abstrativo o sujeito busca o que é comum aos objetos observados, é possível supor que, para o desenvolvimento da generalização empírica, um maior número de manifestações sensorial-concretas propiciaria representações mais seguras. Voltando ao exemplo da vitrina com mamíferos, caso um morcego ou um boto fossem incluídos, o atributo 'quatro patas' causaria problemas ao observador empírico. Além do atributo 'quatro patas' poder colocar o objeto em outra classe (em qualquer outra classe de Tetrapoda), ele pode retirar um objeto da classe 'mamíferos' (por exemplo, no caso do boto em que, externamente, seus quatro membros não estão disponíveis à observação sensorial). Torna-se necessária então a percepção de outras características e de outros animais para fortalecer a formação do conceito 'mamífero'. No pensamento empírico, portanto, quanto maior o contato com a diversidade de objetos relacionados ao conceito que propiciem experiências sensoriais e, consequentemente, quanto maior a possibilidade de observação entre seus atributos essenciais e secundários, mais segura sua generalização.

Entretanto, apesar de Davídov (1982) reconhecer a importância do pensamento empírico para o desenvolvimento conceitual, observa-se em sua obra que ele não o considera 
como realização suficiente para uma interação ampla do indivíduo com seu meio. Para o autor, a capacidade de generalização passa por diferentes níveis e está ligada ao momento do desenvolvimento do indivíduo. Crianças pequenas, em idade pré-escolar, possuem uma generalização baseada na percepção direta, sendo importantes os ambientes ricos em materiais sensorialmente concretos. A seguir, a criança começa a operar cada vez mais com representações, mas permanece ligada aos atributos externos dos objetos. Para ele, é na adolescência que os seres humanos generalizam conceitos baseados em análises sistêmicas das relações e conexões entre os objetos e fenômenos, desvinculando-se de suas características externas e operando com suas qualidades e relações internas, na chamada generalização teórica.

Enquanto no pensamento empírico as associações são estabelecidas a partir dos atributos externos, servindo como organizadoras da realidade, no pensamento teórico distingue-se um nexo interno, um conceito que estava palpavelmente ausente dos dados sensoriais primários (DAVÍDOV, 1982). Assim, o conhecimento teórico é aquele que representa inter-relações entre o interno e o externo, entre a essência e a aparência, entre o original e o derivado. Para ser apropriado, este conhecimento tem que ser transformado, ou seja, o indivíduo precisa reproduzir o processo de sua origem, revelando suas relações internas. É necessário perceber como a aparência externa do objeto se desenvolveu e como depende de suas relações internas. A origem da aparência pode então ser traçada e o objeto dividido em aspectos gerais e particulares. $\mathrm{O}$ indivíduo tem a possibilidade de compreender como o geral e o particular se articulam.

Observa-se assim que as formações do pensamento empírico e do pensamento teórico caminham por traçados diferentes: enquanto o conceito empírico é construído de cima para baixo, no reconhecimento da generalidade e na sua aplicação na identificação do singular, ou seja, do concreto para o abstrato, o conceito teórico é construído de baixo para cima, em um movimento de ascensão do abstrato ao concreto.

Entretanto, como ressalta Davídov (1988), a recriação do concreto está relacionada, fundamentalmente, com o processo de síntese, no qual se dá o processo de análise com a finalidade de obter abstrações. Assim, a atividade de síntese fornece a si mesma as abstrações necessárias e essas reduções da concretude da realidade às suas expressões abstratas tornamse um "aspecto orgânico [...] da atividade sintetizadora da mente" (Davídov, 1988, p. 148, tradução nossa). Dessa forma, o processo teórico é ao mesmo tempo o processo de redução do 
concreto ao abstrato e de ascensão do abstrato ao concreto. Mas, apesar desses dois processos estarem em unidade, é o segundo que expressa a natureza do pensamento teórico.

Davydov (1988b, p. 22, tradução nossa) descreve esse movimento como uma possibilidade para não somente pensar abstratamente com um conjunto de proposições, mas ainda para desenvolver uma instrumentalidade para a ação mental e dá como exemplo o desenvolvimento do pensamento teórico no ambiente escolar:

Quando se movem em busca do domínio de qualquer objeto de estudo escolar, os alunos, com a ajuda do professor, analisam o conteúdo do material curricular e identificam sua relação geral primária; ao mesmo tempo, descobrem que esta relação manifesta-se em muitas outras relações particulares encontradas neste mesmo material. Ao registrar, por meio de alguma forma referencial, a relação geral principal identificada, os alunos constroem, então, uma abstração substantiva do assunto estudado. Continuando sua análise do material curricular, eles evidenciam o vínculo de regulamento entre esta relação primária e suas diversas manifestações obtendo, assim, uma generalização substantiva do assunto estudado.

A seguir, as crianças utilizam consistentemente a abstração e a generalização substantivas para deduzir (novamente com a ajuda do professor) outras abstrações mais particulares e para uni-las no objeto integral (concreto) estudado. Quando os alunos começam a usar a abstração e a generalização primárias como meios para deduzir e unificar outras abstrações, eles convertem as estruturas mentais iniciais em um conceito que representa $\mathrm{o}$ "núcleo" do assunto estudado. Este "núcleo" serve, subseqüentemente, aos estudantes como um princípio geral pelo qual eles podem se orientar em toda a multiplicidade do objeto de estudo escolar fatual, o qual eles têm que assimilar, em uma forma conceitual, via a ascensão do abstrato para o concreto.

Para Davídov (1988), o pensamento teórico não opera com representações, mas com conceitos. Ter um conceito sobre o objeto é "saber reproduzir mentalmente seu conteúdo, construí-lo" (p. 126, tradução nossa). Segundo o autor, "expressar o objeto em forma de conceito significa compreender sua essência” (p. 126, tradução nossa). A importância dessa estrutura de pensamento é que, ao compreender a essência dos objetos, o indivíduo entende como e por que algo se transforma e consegue resolver um problema não somente em relação a uma única situação, mas também a casos semelhantes. Nesse sentido que o conceito é visto, ao mesmo tempo, como um reflexo do ser e uma instrumentalidade da operação mental.

E é justamente essa transformação cognitiva do sujeito o principal resultado obtido da atividade de aprendizagem, como coloca Elkonin (1974 apud DAVÍDOV; MÁRKOVA, 1987, p. 324, tradução nossa):

O resultado da atividade de aprendizagem, no curso da qual tem lugar a assimilação de conhecimentos científicos, é, antes de tudo, a transformação do próprio aluno, seu desenvolvimento. Em geral, pode-se dizer que esta 
transformação é a aquisição pela criança de novas capacidades, ou seja, de novos procedimentos de ação com os conceitos científicos. Assim, a atividade de aprendizagem é, principalmente, aquela atividade cujo produto são as transformações no aluno. Trata-se de uma atividade de autotransformação; nisto consiste sua principal particularidade.

O conteúdo da atividade de aprendizagem é, portanto, o conhecimento teórico, aqui entendido como Davydov (1988b) descreve: a combinação unificada da abstração substantiva, da generalização e do conceitos teóricos. No processo da atividade de aprendizagem, o sujeito reproduz em sua consciência a riqueza teórica acumulada pela humanidade e expressa nas formas ideais da cultura. A atividade de aprendizagem é "uma das rotas pela qual a unidade do histórico e do lógico é realizada no desenvolvimento da cultura humana" (DAVYDOV, 1988 b, p. 22, tradução nossa).

O desenvolvimento dessa rota, desse caminho da apropriação do conhecimento produzido histórica e culturalmente, requer que haja uma organização da atividade de aprendizagem nos espaços que intencionalmente se colocam como educativos. Na perspectiva da teoria da atividade, os aprendizes somente se apropriam do conhecimento teórico por meio da atividade de aprendizagem, quando eles possuem necessidades e motivos para aprender. Da mesma forma, a atividade de ensino requer uma organização da atividade de aprendizagem dotada de intencionalidade, pressupondo também necessidades e motivos.

Davydov (1999a) coloca algumas condições da atividade de ensino. Uma primeira condição é que o processo educativo deve estar fortemente baseado nas necessidades do aprendiz em se apropriar do patrimônio cultural. Embora o aprendiz, sem ter tais necessidades, possa de fato aprender e assimilar conhecimentos, ele não transforma de forma criativa o objeto do aprendizado, pois ele não desenvolveu instrumentos por meio dos quais possa resolver problemas relacionados a esse objeto. Assim, uma boa atividade de ensino/aprendizagem deve favorecer ao indivíduo o desenvolvimento da necessidade de aprender.

Uma segunda condição necessária à atividade de ensino é a formulação de tarefas de aprendizagem elaboradas de tal forma que levem à transformação do objeto pelo sujeito. Davídov e Márkova (1987) definem uma tarefa como a combinação do objetivo da ação e as condições sob as quais esse objetivo pode ser alcançado. Para os autores, as tarefas de aprendizagem apresentadas pelo educador aos aprendizes requerem destes: 
1) a análise do material fatual de tal forma que se descubra nele alguma relação geral que possa ter um vínculo regulatório com as várias manifestações desse material (ou seja, a construção de abstrações e generalizações substantivas).

2) a dedução, baseada na abstração e na generalização, de relações particulares em determinado material e sua unificação (síntese) em algum objeto integral (isto é, a construção do núcleo deste material e o objeto mental concreto).

3) o domínio, no processo de análise e síntese, do modo geral pelo qual o objeto em estudo é construído (DAVÍDOV; MÁRKOVA, 1987, p. 26, tradução nossa).

Ao realizar os processos de análise, síntese e modo de ação geral, o aprendiz completa uma espécie de "microciclo de ascensão do abstrato ao concreto, sendo esta a via pela qual o conhecimento teórico é assimilado" (DAVÍDOV; MÁRKOVA, 1987, p. 27, tradução nossa).

Nesse processo, o educador deve estar atento às ações desenvolvidas pelo aprendiz, sendo algumas delas já bem conhecidas. Para Rubtsov (1996, p. 133), o aprendiz, para resolver as tarefas de aprendizagem, realiza as seguintes ações:

. a transformação de um objeto ou de uma situação com vistas a ressaltar as relações fundamentais do sistema analisado;

. a materialização da relação levantada, sob a forma de objetos, desenhos, símbolos;

- a transformação do modelo dessa relação, a fim de estudar as suas propriedades intrínsecas;

. a valorização e a criação de uma série de problemas concretos e práticos, a serem resolvidos mediante o recurso à forma geral;

. o controle das ações precedentes;

. a avaliação da aquisição da forma geral, considerada como resultado da resolução de um problema de aprendizagem.

Cada uma dessas ações é composta por operações coerentes, que variam conforme cada problema de aprendizagem proposto. Então, um arranjo apropriado da atividade de aprendizagem requer que o educador esteja disposto a elaborar tarefas de aprendizagem que possam ser resolvidas por meio das ações citadas acima. Nesse sentido, um conteúdo fundamental da atividade de ensino seria a organização da atividade de aprendizagem.

Moura (1996) refere-se à atividade de ensino estruturando-a no que chamou de atividade orientadora de ensino, uma atividade organizada para permitir a interação entre os sujeitos mediados por um conteúdo, com a negociação de significados. Para o autor, ela tem o objetivo de solucionar uma situação problema e é atividade orientadora 
porque define os elementos essenciais da ação educativa e respeita a dinâmica das interações que nem sempre chegam a resultados esperados pelo professor. Este estabelece os objetivos, define as ações e elege os instrumentos auxiliares de ensino, porém não detém todo o processo, justamente porque aceita que os sujeitos em interação partilhem significados que se modificam diante do objeto de conhecimento em discussão" (Moura, 2001, p.155).

Assim, a necessidade do educador é ensinar e suas ações definem o modo como os conhecimentos entram em cena no espaço educativo. Ao refletir sobre suas ações e os resultados delas, o educador pode redefinir os modos de organização da atividade e, nesse processo também é formado. Para Moura (1996, 2001), a atividade orientadora de ensino, ao mesmo tempo em que forma o aprendiz, é também formadora do educador.

Apesar desses pressupostos teórico-metodológicos estarem embasados nos processos de desenvolvimento propiciados pela escola, vale refletir sobre as possibilidades colocadas aos museus, principalmente no que se refere ao desenvolvimento psíquico dos sujeitos ativos da sociedade atual.

Como coloca Fayard (1999), ao se considerar a divulgação científica no último século, pode-se observar uma verdadeira "revolução copernicana". O autor acredita que ocorreu uma mudança de práticas de comunicação que partem dos interesses das ciências para outras mais centradas nos interesses e preocupações dos não-especialistas. Fayard afirma que houve, também no último quarto do século passado, o desenvolvimento de necessidades de adaptação da sociedade em uma época de grandes avanços científicos e tecnológicos. Passou-se de um período em que a informação era escassa e de difícil acesso a outra com uma multiplicidade de acessos. Essas mudanças delinearam a situação imposta atualmente: o conhecimento científico passa a girar ao redor do público. Fayard ressalta que, mais importante do que garantir "as maiores quantidades de conhecimento", seria promover a capacidade de criar sentido, a atitude de mobilizar as informações úteis em um momento adequado e em uma lógica de fluxo. Levanta as questões:

Em um mundo multipolar tanto em termos políticos como econômicos, marcado pela diversidade das culturas e de suas confrontações, e ante a necessidade de coexistir em um mundo planetário fechado, qual é o lugar da cultura científica? O que está ocorrendo com os problemas surgidos da dinâmica da relação entre "ciências, técnicas, cultura e sociedade" em um contexto de mundialização econômica, de descontinuidades tecnológicas, de desocupação crescente e redefinição de educadores (FAYARD, 1999, p. 15, tradução nossa)? 
A essas questões somam-se as de Pujol (2002) que, ao acreditar que a ciência constitui um importante elemento dinamizador da sociedade, fonte do desenvolvimento individual e coletivo e que faz parte da cultura humana vinculada ao modelo social de cada grupo, pergunta:

Em que medida a ação educativa oferece elementos para perpetuar um sistema caduco, injusto e insustentável ou para imaginar e construir um sistema mais justo e sustentável para todos os cidadãos (PUJOL, 2002, p. 10, tradução nossa)?

A consideração dessas questões na práxis educativa é de grande importância frente à demanda crescente apresentada pela sociedade em termos de apropriação do conhecimento científico e o aumento nas ações de educação em ciências e divulgação científica. Para Marandino (2001), o movimento de divulgação em ciências fortificou-se nos últimos anos, devido, principalmente, ao aumento do número de revistas científicas, jornais e vídeos e à ampliação do número de museus e centros de ciências, além da especialização do jornalismo científico. A autora salienta ainda que, atrelado a esse movimento, encontra-se o que considera "um movimento social mais amplo", o de alfabetização científica do cidadão, manifestado tanto em propostas de educação formais como não-formais. Os museus de ciências, entre os ambientes educacionais reconhecidos como não-formais (segundo SMITH, 2001; MARANDINO et al., 2003), encontram-se atualmente bastante engajados nos processos de formação de cidadãos criticamente posicionados frente à ciência (VAN-PRAËT, 2005). Mas, como os museus têm pensado essa formação? Considerando a apropriação de conhecimentos teóricos como fundamental para a transformação do sujeito, qual tipo de pensamento, o teórico ou o abstrato, tem sido priorizado por essas instituições?

Em museus de ciências, em que o conhecimento científico ${ }^{30}$ é elemento fundamental, essa questão deve ser vista com especial atenção. Os conceitos científicos são conhecimentos teóricos, produzidos e sistematizados em outros contextos que não o do museu, a partir de observações realizadas por outros sujeitos, em outros tempos. Ao serem trazidos ao museu, distanciam-se de seu contexto de origem, sofrem "transposição museográfica" (cf. MARANDINO, 2001. Nesse movimento, os conceitos científicos passam a ter um caráter cada vez menos evidente ou preso à experiência.

Apesar de carregados de conhecimento teórico, os museus de ciências, em geral, dispõem seus conteúdos ao visitante com tal arranjamento que prioriza o desenvolvimento do

30 Conhecimento das ciências. 
conhecimento empírico. As vitrinas dos museus de história natural que expõem um número considerável de organismos ao público para observação direta ou os centros de ciências que promovem a "interatividade física" por meio de aparatos que emitem sons e luzes ligados diretamente a determinados atributos de objetos ou fenômenos estão favorecendo o desenvolvimento do pensamento empírico, por meio da formação de conceitos de maneira empírica, pois estimulam o visitante a observarem suas características externas, imediatas à percepção.

Cabe então um questionamento: em um mundo em que a extroversão do desenvolvimento científico e tecnológico é cada vez mais posta aos seus habitantes, exigindo que os conceitos científicos teóricos sejam usados como instrumentalidade para resoluções de problemas diversos, qual o papel dos museus de ciências no desenvolvimento do pensamento teórico?

Observa-se assim, a necessidade de reflexão sobre a função educativa dessas instituições e a sua importância no desenvolvimento desse tipo de pensamento para a formação de cidadãos críticos em relação à ciência. Concorda-se com Sforni (2004, p. 77) que, considerando o ambiente escolar, vê

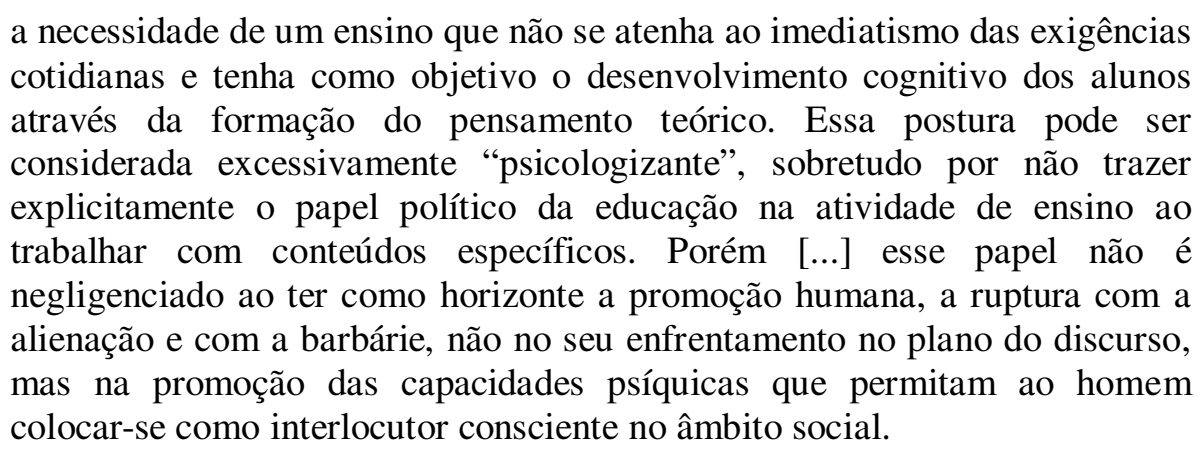

Olhar para os conceitos não como entidades isoladas, estáveis, detidas pelo sujeito, mas como elementos de um sistema complexo de inter-relações, um produto de processos de construção coletiva de significações que liberta o ser humano das impressões imediatas (OLIVEIRA, 1999) torna-se um pressuposto importante da pesquisa sobre aprendizagem em museus. Nesse sentido, a teoria da atividade, ao enfatizar a transformação do mundo pelo homem, mediatizada por signos como os conceitos teóricos, pode ser considerada como um referencial poderoso para a compreensão do processo de aprendizagem nessas instituições. Se, como afirma Davidov, os conteúdos e procedimentos usados no processo didático-educativo determinam o tipo de consciência e pensamento formados no indivíduo, é possível imaginar 
que os discursos expositivos museais podem mais do que transmitir conceitos científicos, podem ajudar a construir significados relacionados à ciência.

\subsection{ATIVIDADE DE APRENDIZAGEM E MUSEUS DE CIÊNCIAS}

Como visto no capítulo anterior, as pesquisas sobre aprendizagem em museus desenvolveram-se consideravelmente nas duas últimas décadas, com diálogo constante entre grupos de pesquisadores de diferentes países e com uma ampla gama de abordagens teóricometodológicas (FALK, 2001; HOOPER-GRENHILL, 1999a; RENNIE; JOHNSTON, 2004). Entretanto, dentro dessa diversidade de possibilidades de pesquisa, encontram-se algumas escolhas comuns a investigadores desses diferentes grupos.

A primeira delas é a utilização de referenciais socioculturais para a compreensão dos processos de aprendizagem desenvolvidos na relação dos públicos com os museus. Com essa escolha, vários pesquisadores optam por analisar as conversas estabelecidas entre membros de um grupo, seja ele escolar ou familiar (LEINHARDT; CROWLEY, 2002). Muitas vezes, essas interações conversacionais são estudadas de forma integrada a um ou mais elementos dos contextos pessoal, social e físico, conforme proposto por Falk e Dierking (2000).

Entretanto, entre essas abordagens teórico-metodológicas, são raras as pesquisas que utilizam os estudos desenvolvidos por Leontiev a partir das ideias de Vigotski e outros estudiosos da psicologia sociocultural, como a Teoria da Atividade, no contexto dos museus. Embora alguns autores reconheçam a importância dessas ideias para o estudo da aprendizagem nesses espaços (INSULANDER, 2005; MATUSOV; ROGOFF, 1995; ROWE, 2002), poucas são as pesquisas investigativas desenvolvidas na área (exceções são ASH; WELLS, 2007; NASCIMENTO, 2007 e ROWE, 2002).

Em um capítulo do livro "Perspectives on Object-Centered Learning in Museums", Rowe (2002), da Washington University, ressalta a importância de uma abordagem de pesquisa que leve em consideração a construção de significado ativa e distribuída para se entender as experiências museais dos visitantes. Para o autor, os museus fornecem uma boa oportunidade de compreender as atividades de grupo que rotulamos como aprendizagem. Mas, o que torna esses locais propícios para pesquisa sob a perspectiva da Teoria da Atividade? Segundo Rowe, isso se dá porque as visitas aos museus, em geral, são realizadas em grupo e, além disso, as exposições fornecem múltiplas formas de interação e diferentes formas de organização da atividade social, por meio do uso de objetos. 
Entretanto, Lompscher e Hedegaard (1999), apoiados por vários outros autores (p. e., LIBÂNEO, 2004; SERRÃO, 2004; SFORNI, 2004), enfatizam que é a escola o espaço em que as crianças, em um processo gradual, encontram novas normas, exigências, condições e, principalmente, novos objetos e conteúdos a serem apropriados, ou seja, inserem-se em atividades de aprendizagem. Haja vista essa restrição, cabe avaliar se as bases desse conceito (o de atividade de aprendizagem) poderiam ser utilizadas para analisar a estruturação da aprendizagem enquanto atividade em um outro contexto educativo que não a escola.

É importante resgatar de Davídov e Márkova (1987, p. 318, tradução nossa) que há subsídios para supor que,

certas teses gerais dessa teoria [concepção da atividade de aprendizagem] podem ser aplicadas em determinada medida não somente ao ensino escolar, mas também a outras instituições de instrução pública relacionadas (por exemplo, o ensino no jardim de infância, nos centros de estudos especializados, nas escolas superiores); sem dúvida, os autores não conseguem expressar opiniões mais definitivas sobre este problema, pois ele exige uma análise especial e minuciosa.

Nessa perspectiva, frente à necessidade de investigações sobre a atividade de aprendizagem em outros contextos, esse trabalho se propõe a compreender como seria, então, estruturada uma atividade de aprendizagem em um museu de ciências, bem como a compreender como estariam representados os diferentes elementos constituintes de um sistema dessa atividade coletiva nesses espaços. Essa abordagem distingue essa investigação de outros raros trabalhos que utilizam a Teoria da Atividade para analisar o espaço museal.

No estudo desenvolvido por Rowe (2002), o autor procura analisar o papel dos aparatos museais para a construção de significados entre membros de grupos de visitantes. Ressalta que, em parte, o que faz dos museus um local único de aprendizagem é o fato de que modos múltiplos de interagir acerca de e com objetos são incentivados. Para ele, a "natureza da atividade e o significado do objeto nos museus estão prontos para negociação entre os visitantes" (ROWE, 2002, p. 21, tradução nossa). Assim, “compreender como a atividade de um grupo desenrola-se em um museu envolve investigar como essas ações são conjuntamente negociadas, apropriadas e desdobradas" (ROWE, 2002, p. 22, tradução nossa).

A partir de observações de famílias interagindo com um aparato relacionado a conceitos da Física (The Great Gravity Race, sobre planos inclinados), Rowe busca compreender quais as ações desenvolvidas por essas famílias e como essas ações levam à construção de significados compartilhados por seus membros. Levanta, assim, os principais 
modos de interação que cada família estabelece, o que denominou de "modos de saber" (ways of knowing) sobre o aparato. Os modos de saber criados pelo autor referem-se intimamente ao aparato investigado, apresentando um caráter que poderia ser relacionado à aprendizagem situada proposta por Lave e Wenger $(1991)^{31}$. Assim, o modo "jogo" (racing) refere-se às ações em que as famílias apropriam-se do caráter lúdico, competitivo do aparato (o próprio nome do aparato analisado sugere a competição). Em geral, esse era o primeiro "modo de saber" apresentado pelos grupos. Após as primeiras interações com o aparato, as famílias apresentavam outros "modos de saber", denominados pelo autor de "participação guiada" (guided participation), exemplificada pelas conversas do tipo IRF Iniciação/Resposta/Feedback ${ }^{32}$, e "pensando como um cientista" (thinking like a scientist), relacionadas aos momentos em que os visitantes pareciam engajar-se nos tipos de atividades consideradas como os pontos principais do aparato, "observando, criando hipóteses e controlando variáveis" (ROWE, 2002, p. 29, tradução nossa).

Rowe salienta que, se sua pergunta de pesquisa fosse "esse aparato consegue adequadamente ilustrar o que o museu decidiu ser a interpretação correta desse objeto?", estaria preso somente à função primeira que Lotman (1994) atribui aos objetos: a de transmissão de informações. Nesse caso, o aparato estudado cumpriria sua função de transmissão de informações, já que as famílias "moldaram” suas ações a partir daquilo que era sugerido pela voz do museu expressa nas legendas do aparato e desenvolveram ações condizentes com o que o museu consideraria "pensar como um cientista". Entretanto, para o autor, o museu deveria ter considerado ainda a segunda função do objeto colocada por Lotman, a de propiciar a construção de novos significados pelo visitante, compartilhando a autoridade de interpretação com o seu público, o que não foi observado.

Em outra proposta de investigação sobre aprendizagem em museus sob o enfoque da Teoria da Atividade, Nascimento (2007) também direciona sua análise ao nível da ação. Entretanto, ao contrário de Rowe, que constrói suas categorias a partir dos dados obtidos, a autora apresenta ferramentas de análise construídas a priori, a serem aplicadas em eixos definidos: o situacional, o comunicacional e o epistemológico. No eixo situacional, seriam analisados o contexto e a funcionalidade (operações e ações dos interlocutores). No eixo comunicacional, propõe a análise das interações (a partir dos padrões interacionais) e das estratégias de engajamento e explicação utilizadas. No eixo epistemológico, sugere a análise

\footnotetext{
31 Entretanto, o autor salienta o caráter distribuído da aprendizagem centrada em objetos, mesmo citando Jean Lave e Ettiene Wenger.

32 No original: IRE - Initiation/Response/Evaluation.
} 
proposicional de saberes tecnológicos e científicos, já que tratamos de museus de ciências (Figura 4).

\begin{tabular}{|c|c|c|c|}
\hline EIXOS & COMPONENTES & MÉTODOS DE ANÁLISE & RESULTADOS \\
\hline \multirow{3}{*}{ Situacional } & Contexto & \multirow{3}{*}{$\begin{array}{l}\text { Análise cronológica, } \\
\text { observação direta e } \\
\text { vídeo-observação }\end{array}$} & Protocolo efetivo \\
\hline & \multirow[b]{2}{*}{ Funcionalidade } & & Quadros de narrativas \\
\hline & & & $\begin{array}{l}\text { Operações e Ações } \\
\text { dos interlocutores }\end{array}$ \\
\hline \multirow{4}{*}{ Comunicacional } & & & Capital de fala \\
\hline & Interação & Análise de interações & Papéis de fala \\
\hline & & & Padrões interacionais \\
\hline & Estratégica & Análise proposicional & $\begin{array}{l}\text { Estratégia de engajamento } \\
\text { Estratégia de explicação }\end{array}$ \\
\hline \multirow{3}{*}{ Epistemológico } & Saberes tecnológicos & \multirow{3}{*}{ Análise proposicional } & Descrição de objetos \\
\hline & \multirow{2}{*}{ Saberes científicos } & & Processos de construção \\
\hline & & & Princípios de funcionamento \\
\hline
\end{tabular}

Figura 4 - Quadro com ferramentas de análise de eixos discursivos (NASCIMENTO, 2007).

Em outro estudo recente, apresentado como um capítulo de um livro elaborado para educadores e pesquisadores de espaços de "educação informal" 33, Ash e Wells (2006) utilizaram-se da Teoria da Atividade para "comparar e contrastar interações do tipo dialogic inquiry em museus e na sala de aula, para descobrir princípios comuns de aprendizagem nesses espaços" (p. 35, tradução nossa). Os autores analisaram dados obtidos de diálogos conversacionais de uma família interagindo em um museu com um programa de computador sobre evolução e de alunos e professores em uma aula em que o conceito de massa era o objeto de estudo. Em suas conclusões ressaltam que, apesar das diferenças no número de participantes, no tipo de ambiente, no tipo de mediação, no conteúdo disciplinar, no tempo disponível, entre outros, ainda assim algumas características eram similares. Nos dois casos, “o objeto 1) foi mediado coletivamente, envolvendo tanto o fazer quanto a fala; 2) estava situado em um discurso no qual cada contribuição individual tanto respondeu ao que precedia como antecipou o diálogo seguinte; 3) incorporou uma variedade de artefatos; 4) envolveu resultados que foram gradualmente e continuamente transformados; e 5) levou os aprendizes a

33 Na língua inglesa, o termo "educação não formal" é raramente utilizado. Geralmente, os museus são considerados instituições de "educação informal” em trabalhos publicados nesse idioma. 
ideias interessantes e intelectualmente honestas" (ASH; WELLS, 2006, p. 50, tradução nossa). Para Ash e Wells, as diferenças na organização da atividade não estão relacionadas à formalidade ou informalidade do ambiente educacional, mas são respostas aos limites dos contextos em que cada aprendizagem ocorre.

No presente trabalho, não há a pretensão de delimitar convergências e divergências entre os processos de aprendizagem em museus e escolas, mas sim compreender como se estruturaria uma atividade de aprendizagem no contexto museal, com vistas a entender como a organização dessa atividade poderia otimizar o processo de aprendizagem nesses espaços educativos.

Com o referencial histórico-cultural em mente, buscou-se traçar uma abordagem metodológica que fornecesse elementos para refletir sobre as questões colocadas. Vale ressaltar que os problemas iniciais de pesquisa, suscitados na prática profissional em um museu de ciências, foram posteriormente acompanhadas de novas questões surgidas a partir do momento em que este referencial teórico foi escolhido para ajudar a compreender a realidade do museu. Assim, a questão inicial "como se dão as relações estabelecidas entre grupos de visitantes e o discurso expositivo de museus de ciências em um processo de aprendizagem ? $^{34,}$ ampliou-se, mas, ao mesmo tempo, focou-se ao abarcar a Teoria da Atividade.

Procurou-se então entender como está estruturada a atividade de ensino/aprendizagem em um museu de ciências, especificamente o Museu Biológico do Instituto Butantan, levando em consideração os elementos da Teoria da Atividade, pensando sobre a dualidade da função do objeto museal, o potencial semiótico dos objetos-artefatos, as ferramentas históricas e culturais presentes nos museus de ciências e, principalmente, a importância da interação sujeito-sujeito dentro e fora de um grupo de visitantes. Além disso, ao serem considerados os ciclos expansivos da atividade, buscou-se analisar ainda as tensões e contradições internas desse sistema, em uma perspectiva histórica. Dessa forma, o próximo capítulo (Capítulo 3) apresenta a construção da atividade de ensino/aprendizagem realizada pelo e no Instituto Butantan ao longo do século XX, analisando-se suas tensões e contradições, acentuadas pelas transformações contínuas dos elementos constituintes desse sistema de atividade, que levaram à constituição e ao uso da atual exposição de longa duração de seu primeiro museu. No capítulo seguinte (Capítulo 4), muda-se a escala de análise, mas se mantém a unidade de

34 Essa questão foi apresentada no projeto de pesquisa depositado junto à Faculdade de Educação da Universidade de São Paulo, a fim de participar do Processo de Seleção para o Programa de Pós-Graduação.

Essa questão foi alterada ao longo da inserção da doutoranda no Programa. 
análise: a atividade de ensino/aprendizagem, agora em visitas realizadas ao museu por grupos familiares com adultos e crianças. Pretende-se, assim, compreender a atividade de aprendizagem da família em um museu de ciências não somente de forma pontual, a partir das elaborações conversacionais realizadas durante a visita, mas de forma dinâmica, em movimento, fazendo parte de um sistema de atividade coletiva maior: a atividade de ensino/aprendizagem. 
Capítulo 3

A origem e o desenvolvimento da atividade de ensino/aprendizagem no Instituto Butantan 



\section{A ORIGEM E O DESENVOLVIMENTO DA ATIVIDADE DE ENSINO/APRENDIZAGEM NO INSTITUTO BUTANTAN}

Divulgar as pesquisas desenvolvidas pelo Instituto Butantan, promovendo uma maior compreensão pelo público dos avanços científicos ali realizados, é uma das missões dessa instituição que mais continuamente aparecem em seus relatórios internos, materiais institucionais ou propostas educativas. Ao longo do século XX, o Butantan desenvolveu numerosas pesquisas em diferentes áreas de conhecimento e comunicou ao público uma visão de ciência e de produtos científicos derivados do conhecimento gerado.

Entretanto, diante da grande variedade de linhas de pesquisas desenvolvidas, como nas áreas de Patologia, Biotecnologia, Bioterismo ou Imunologia Viral, somente algumas foram priorizadas em seu discurso expositivo. Mas como se deu essa construção? Por que o público, ao imaginar as atividades realizadas pelo Instituto Butantan, remete-se preferencialmente aos estudos com serpentes e à produção de soro antiofídico? Qual o papel do Museu Biológico, um dos principais agentes de extroversão da ciência da instituição ao longo do século, na construção de um imaginário coletivo sobre o Butantan? Essas questões norteiam este capítulo, pelo qual se pretende traçar um breve histórico da atividade de ensino/aprendizagem ${ }^{35}$ desenvolvida por essa instituição, enfatizando alguns de seus elementos, como as necessidades dos sujeitos, seus motivos, suas ações e os resultados alcançados. Além disso, busca-se revelar mudanças e permanências nas atividades coletivas, em relação aos atores envolvidos, às formas que adquiriram em diferentes contextos e épocas e à relação estabelecida entre ciência e público. Essas reflexões são úteis para o entendimento de como as atividades de ensino desenvolvidas no Instituto Butantan ao longo do século, principalmente no Museu Biológico, ajudaram a determinar o seu atual discurso expositivo e, principalmente, para a compreensão das práticas de divulgação e educação dessa instituição como atividades de ensino/aprendizagem na perspectiva da Teoria da Atividade.

Para isso, foram analisadas fontes documentais primárias: os relatórios anuais da instituição, entre os anos de 1901 e 1990; o acervo iconográfico depositado na Biblioteca do

\footnotetext{
${ }^{35}$ São claras a multivocalidade e a polissemia existente quando se citam os termos divulgação científica, educação não formal em ciências, comunicação pública da ciência, entre outros. Nesse trabalho, quando se menciona "atividade de ensino/aprendizagem", não se pretende unificar todos esses campos de atividade em um único conceito. O que se pretende é criar uma unidade de análise pela qual se possa compreender as ações realizadas por diferentes sujeitos orientadas para um objeto relacionado a um motivo específico: ensinar, divulgar, comunicar a cultura científica, buscando como resultado a aprendizagem e consequente formação dos indivíduos. Nesse movimento, é atividade também de aprendizagem, pois o educador, ao avaliar seus resultados, apropria-se de novos elementos da cultura para a criação de novas formas de ensino.
} 
Instituto; revistas periódicas de divulgação publicadas entre 1940 e 1955, bem como materiais de divulgação científica e educação em ciências presentes no acervo do Laboratório Especial de História da Ciência do Instituto Butantan e parte do acervo pessoal do Prof. Henrique Moises Canter, atual diretor da Divisão de Desenvolvimento Cultural desse instituto. Além disso, foram consultados livros e documentários produzidos por funcionários do Instituto Butantan ao longo do século XX. Está-se ciente de que essa opção de coleta de dados restringiu a pesquisa ao viés institucional e que é possível, e desejável, ampliar a análise a partir de resgates históricos das falas de pessoas que participaram ou participam do cotidiano da instituição. As entrevistas de memória oral também são consideradas como fontes para a compreensão do passado, juntamente com documentos escritos, imagens ou outros registros, com a particularidade de fornecerem uma maior compreensão de como os indivíduos (como constituintes das instituições) interpretam situações e acontecimentos de um determinado período.

Logo, apresenta-se uma análise das estratégias de divulgação científica e educação em ciências desenvolvidas ao longo do século XX na Instituição, a partir de dados retirados, principalmente, dos registros oficiais. Vale ressaltar que, inicialmente e ao longo do capítulo, são trazidos elementos desses processos nos cenários nacional e internacional, relacionados principalmente aos museus de ciências, no momento anterior à implantação do Instituto Butantan. Essa ilustração colabora para um melhor entendimento dos processos de divulgação científica e a educação em ciências fora do ambiente escolar, bem como mostra o terreno fértil em que se iniciaram as atuais atividades de ensino/aprendizagem do Instituto Butantan e contextualiza as transformações sofridas por essas estruturas ao longo do século.

\subsection{A DIVULGAÇÃO CIENTÍFICA E A EDUCAÇÃO EM CIÊNCIAS NO MUNDO: EUFORIA NA SEGUNDA METADE DO SÉCULO XIX}

O Instituto Butantan surgiu em uma época em que a divulgação científica, no Brasil e no mundo, apresentava uma retração, um marasmo, após uma onda de otimismo ocorrida na segunda metade do século XIX (MASSARANI E MOREIRA, 2004). Essa retração não é bem compreendida, mas se tornou evidente frente às numerosas iniciativas de comunicação da ciência que a precederam. Nesse momento de euforia em relação às ciências, as atividades de divulgação científica intensificaram-se em vários países, frente aos benefícios dos avanços tecnocientíficos decorrentes da Revolução Industrial. Como conseqüência, o conceito de 
"ciência" assim como um conjunto de termos técnicos e científicos deixaram de estar restritos a círculos de eruditos e adentraram, cada vez mais, na vida cotidiana (PANZA; PRESAS, 2002). A ciência passou a ser vista como fonte de elevação moral e os cidadãos procuravam formas de se apropriar desse conhecimento possível de gerar melhorias em sua qualidade de vida (MASSARANI; MOREIRA, 2004).

Entretanto, esse avanço da comunicação científica nos países industrializados, nesse período, somente pôde ser observado devido à ocorrência de um tecido social urbano (formado no século XVIII) considerado como a audiência por excelência dos avanços científicos (MALET, 2002). Aliado a isso, como ressaltam Panza e Presas (2002), o crescimento das inovações técnicas permitiram uma expansão dos meios de comunicação impressos, apoiando, ainda mais, uma expansão das atividades de divulgação científica. Para os autores, esses dois eventos estão interligados: o desenvolvimento da técnica só se tornou relevante frente a um aumento significativo do nível educativo da população, o que poderia acarretar na maior possibilidade de que a ciência se tornasse um objeto de interesse de um número maior de indivíduos.

A escolaridade crescente observada na segunda metade do século XIX constituiu-se como fruto de ações governamentais, enquanto projeto político, em nações onde o estado tomou para si uma maior responsabilidade pelos serviços sociais e de educação (HEIN, 1998). Para George Hein, várias instituições propuseram-se a prover educação para as "massas", sendo que os museus apareceram, nesse contexto, como um dos agentes capazes de ajudar as pessoas "a apreciarem o valor da vida moderna". Assim, capacitar os cidadãos a lidar com o mundo das máquinas passou a ser objetivo de várias instituições, principalmente dos museus de ciência.

Essa onda de otimismo em relação à divulgação científica teve uma expressiva representação, ainda, nas grandes exposições universais e internacionais e nas exposições nacionais (MASSARANI; MOREIRA, 2004). Enquanto as primeiras versavam sobre temas científicos e tecnológicos mais amplos, as nacionais restringiam-se em público e temáticas.

A primeira Exposição Internacional, no senso moderno do termo, deu-se em 1851, na capital da Inglaterra, nação que, não por acaso, liderou o desenvolvimento do poder industrial. Nos trinta anos seguintes, foram oito grandes exposições, apresentadas com diferenças em área (de 10ha a 233ha), número de países participantes ( 25 a 42), número de visitantes ( 5 a 15 milhões) e custos. Esses eventos iniciais, bastante populares, logo deram origem a conflitos de interesse entre países, acirrados pela dimensão competitiva, quase sempre explícita, dos 
exibicionismos nacionalistas. Como cita Bennett (1998), as nações eram condecoradas com medalhas e prêmios e ranqueadas em cerimônias semelhantes aos Jogos Olímpicos.

A ênfase na aplicabilidade da ciência e das artes industriais, característica marcante da divulgação científica na segunda metade do século XIX e fortemente expressa nesses eventos, reflete-se ainda hoje nas exposições universais: "indústria química", "transporte”, "pecuária”, "cereais", "piscicultura", "meteorologia" são alguns dos temas recentes que mostram a permanente valorização das ciências aplicadas.

A influência das exposições internacionais de meados do século XIX e início do XX nas suas representações atuais não está restrita às suas gerências e determinações. Ao serem apresentadas ao grande público, trouxeram com elas disciplinas e técnicas de exibição que haviam sido desenvolvidas historicamente dentro de museus e galerias. Dessa forma, esses

mecanismos foram traduzidos em modos expositivos que, ao ordenar objetos para a observação do público e ordenando o próprio público que os examinava, tiveram profunda influência no desenvolvimento subseqüente dos museus, galerias e exposições (BENNETT, 1995). Além disso, o interesse manifestado pelas exposições internacionais justificou, em parte, o surgimento e a ampliação de museus em vários países do mundo, que deixaram de difundir exclusivamente a cultura clássica e buscaram divulgar coleções com diretrizes mais populares (VALENTE, 2003).

A participação do Brasil nessas exposições, que ocorreu desde 1862 (em sua terceira edição), reflete um movimento também observado em nosso país. Se houve uma grande euforia em relação à ciência e à divulgação científica na segunda metade do século XIX na Europa, representada no aumento de iniciativas relacionadas à tecnologia impressa e à educação popular, pode-se dizer que, em escala bem menor, o Brasil foi atingido, enquanto colônia portuguesa na América, por evento semelhante (MASSARANI; MOREIRA, 2004).

\subsubsection{O euforismo científico no Brasil: particularidades e modismos}

Embora fortemente influenciadas pela divulgação científica e educação em ciências dos países imperiais, as colônias americanas e asiáticas desenvolveram processos internos com características específicas (MOREIRA; MASSARANI, 2002). No Brasil, embora os pressupostos da divulgação realizada fossem muito semelhantes aos europeus (comunicação baseada na aplicação das ciências às artes industriais), foram observadas características particulares. 
O contexto sócio-político nacional no século XIX, representado recorrentemente por dois momentos especiais - a transferência da corte portuguesa e a ebulição cultural dos anos 1870 - impôs uma dinâmica de definição e reformulação das instituições científicas, fortalecendo o processo de institucionalização da ciência no país. Nesse sentido, a visão de Lopes (1997), na qual esses dois momentos foram cruciais para a formação dos museus brasileiros, poderia ser ampliada para outras expressões institucionais das ciências, como centros de pesquisa, associações científicas ou universidades. Isso porque, com a chegada da corte, no início do XIX, vieram a abertura dos portos e a liberação da imprensa no país ${ }^{36}$, condições fundamentais para o posterior desenvolvimento de publicações nacionais, como revistas, jornais e livros, bem como do conjunto de modificações sociais que disso resultou.

O fortalecimento do meio de comunicação impresso foi significativo para a divulgação científica no país. Como apontam Moreira e Massarani (2002), foi grande o número de periódicos publicados durante o século XIX: das 7.000 revistas criadas no país, 300 estavam relacionadas à ciência ${ }^{37}$. Além do avanço das revistas científicas (acadêmicas e/ou de divulgação) no país, o fortalecimento do meio impresso favoreceu o aparecimento dos primeiros livros dedicados essencialmente à extroversão pública da ciência publicados no Brasil.

Entretanto, a "onda" de otimismo em relação à ciência e sua divulgação não é vinculada somente ao desenvolvimento tecnológico da mídia impressa. Aliado a esse processo, observa-se o que Orville Derby, diretor da Comissão Geográfica e Geológica de São Paulo, descreveu em seu artigo "The Present State of Science in Brazill, publicado no primeiro volume da Revista Science (DERBY, 1883, p. 211, tradução nossa), como um recente "despertar do Brasil em relação à pesquisa científica e a inauguração do que poderia ser denominado de um novo movimento que, até onde o autor está ciente, nenhum relato foi dado ainda ao mundo exterior". Para Derby, esse olhar mais direcionado para a importância da pesquisa científica foi marcado pelas reformas ocorridas em diversas instituições de pesquisa na década de 1870 (DERBY, 1883) ${ }^{38}$. Esse processo de modernização que

\footnotetext{
${ }^{36}$ Como afirmam Alfonso-Goldfarb e Ferraz (2002), as possibilidades de leitura na colônia eram controladas pelo governo, que proibia impressões, decidia o que era publicado e selecionava a entrada de impressos. Assim, os portos eram barreiras extremamente seletivas, onde a maioria dos impressos era descartada no mar.

${ }^{37}$ Como exemplos de periódicos dedicados a "vulgarizar as ciências, letras, artes, agricultura, comércio e indústria", os autores citam a Revista Brazileira - Jornal de Sciencias, Letras e Artes, criada em 1857, a Revista do Rio de Janeiro, de 1867 e a Ciência para o Povo, de 1881.

${ }^{38}$ Vale ressaltar que esse artigo de Orville Derby, publicado no primeiro volume da Science Magazine, é citado por vários autores, com diferentes propósitos: enquanto Figueirôa (1992) salienta uma visão positiva em relação ao cientificismo brasileiro (frente à formação de uma elite intelectual e ao surgimento de iniciativas
} 
caracterizou o último quarto do século, baseado na política agroexportadora, pautou-se não apenas no discurso das ciências, mas em ações concretas. Como afirma Lopes (1997, p. 156):

$\mathrm{Na}$ busca de soluções para o interesse dessa elite agrária, de parcelas das classes médias urbanizadas e das comunidades científicas já então consolidadas, buscaram-se onde foi conveniente, também no âmbito das ciências, modelos institucionais e tradições científicas de diferentes origens, para atingir os ideais de progresso típicos do final do século XIX por meio de um caminho necessariamente próprio. Assim, para a viabilização desses ideais obedeceu-se a padrões internacionais, contrataram-se especialistas estrangeiros, contextualizaram-se novos modelos institucionais vigentes em diferentes países e, incorporando o ideário positivo evolucionista em suas diferentes vertentes e de formas originais, procurou-se compreender e intervir na realidade social do país, também pela renovação e multiplicação das instituições científicas.

Vê-se assim que, se por um lado, a divulgação científica brasileira no período refletiu modificações internas de institucionalização da ciência, por outro, seguiu um movimento internacional de euforia em relação à comunicação dos avanços científicos e tecnológicos pós-Revolução Industrial.

Os museus de ciências representam muito bem esse movimento pendular entre os contextos nacional e internacional: responderam, por um lado, a ações internas de organização da ciência e, por outro, ao "movimento internacional de museus" que ocorria em consonância com as mudanças nas Ciências Naturais do final do século XIX (LOPES, 1997). Enquanto na Europa floresciam várias instituições museais vinculadas aos critérios e aos modos de desenvolvimento da ciência (VALENTE, 2003), no Brasil, ocorreu o surgimento ou a reestruturação de diversos museus por todo o território. Exemplo tradicional é a criação do Museu Paraense Emílio Goeldi, em 1866, e do Museu Paulista, em 1894, ambos dedicados às ciências naturais. Mas, certamente, a reorganização do Museu Nacional do Rio de Janeiro, sob a direção de Ladislau Neto, reflete adequadamente esse período conhecido como a "época de ouro dos museus brasileiros".

Além da produção de materiais impressos e do fortalecimento das instituições museais como comunicadoras da ciência, outras estratégias tomaram corpo nesse período.

As conferências públicas, por exemplo, foram elaboradas inicialmente por diferentes museus, mas posteriormente passaram a ocupar espaços não-institucionais. As palestras (ou cursos científicos) procuravam atingir um público mais diversificado, embora ainda estivessem restritas prioritariamente a uma elite intelectual masculina. Como aponta Alves 
(2001), as conferências foram pensadas, no caso do Museu Paulista, com o objetivo de "estimular a comunicação com as massas", mas eram solicitadas principalmente por universidades ou associações científicas, constituindo-se como "testemunhos de uma relação entre pares" ou como uma atividade de cunho formativo para estudantes de nível superior, considerados como "seleta assistência".

Entre as iniciativas que se sobressaíram com resultados mais positivos quanto ao intuito de popularização, estão as "Conferências Populares da Glória". Realizadas em escolas públicas da Freguesia da Glória, no Rio de Janeiro, iniciaram-se, segundo Fonseca (1996), em 1873, sob coordenação de Manoel Francisco Correia, senador do Império ${ }^{39}$.

É possível considerar que essas conferências assumiam uma maior penetração junto ao público, pois eram continuamente anunciadas em jornais da época (Jornal do Commercio, Gazeta de Notícias e Diário do Rio de Janeiro) ou mesmo publicadas em sua íntegra (FONSECA, 1996; MOREIRA; MASSARANI, 2002). Entretanto, vale ressaltar que a população brasileira de então possuía alto índice de analfabetismo e, embora publicadas em jornais importantes e de maior abrangência, as conferências ainda assim estavam restritas a "um seleto público, sendo notada a presença da família imperial, da aristocracia da corte, de profissionais liberais e estudantes" (FONSECA, 1996, p. 136). Efeito semelhante ocorreu com os cursos preparados pelo Museu Nacional do Rio de Janeiro: Ladislau Netto relata que a audiência variava a cada sessão, "acorrendo para os salões um público improvisado todas as vezes que a carruagem do imperador era vista à porta do museu"40 (LOPES, 1997, p. 188).

Outra iniciativa de divulgação científica e educação em ciências que teve certa representatividade no contexto nacional (embora bem mais limitada que em países industrializados), nesse momento, foi a elaboração das Exposições Nacionais. Consideradas como preparatórias para a participação do país nas Exposições Internacionais, constituíram-se como elementos importantes de divulgação da aplicabilidade da ciência (MOREIRA; MASSARANI, 2002). Segundo os autores, o Brasil participou de cinco exposições internacionais gerais (exposições universais), além das internacionais de temas específicos. Na Exposição Internacional de Higiene de Dresden, na Alemanha (que suscitou a posterior

\footnotetext{
${ }^{39}$ Ocorriam geralmente nas manhãs de domingo e, posteriormente, em dias da semana. Versavam, segundo levantamento realizado pela autora, sobre temas variados, como literatura, educação, teatro, ou ainda sobre temáticas específicas das diferentes ciências, como as conferências intituladas "O modo de viver das plantas", ministrada por José de Saldanha da Gama, ou "Das paixões, suas influências sobre os principais atos orgânicos", ministrada por Feliciano Pinheiro de Bittencourt.

${ }^{40}$ Assim, propôs a alteração de cursos longos, com mais de 15 aulas, inicialmente considerados extremamente profícuos, para conferências em que cada professor apresentasse seus próprios trabalhos ou sinopses gerais de assuntos científicos contemporâneos.
} 
formação do German Hygiene Museum), em 1911, o Instituto Oswaldo Cruz recebeu diploma de honra por sua atuação na área de protozoologia, principalmente pelos estudos de Carlos Chagas (FUNDAÇÃO OSWALDO CRUZ, 2003) (Figura 5).

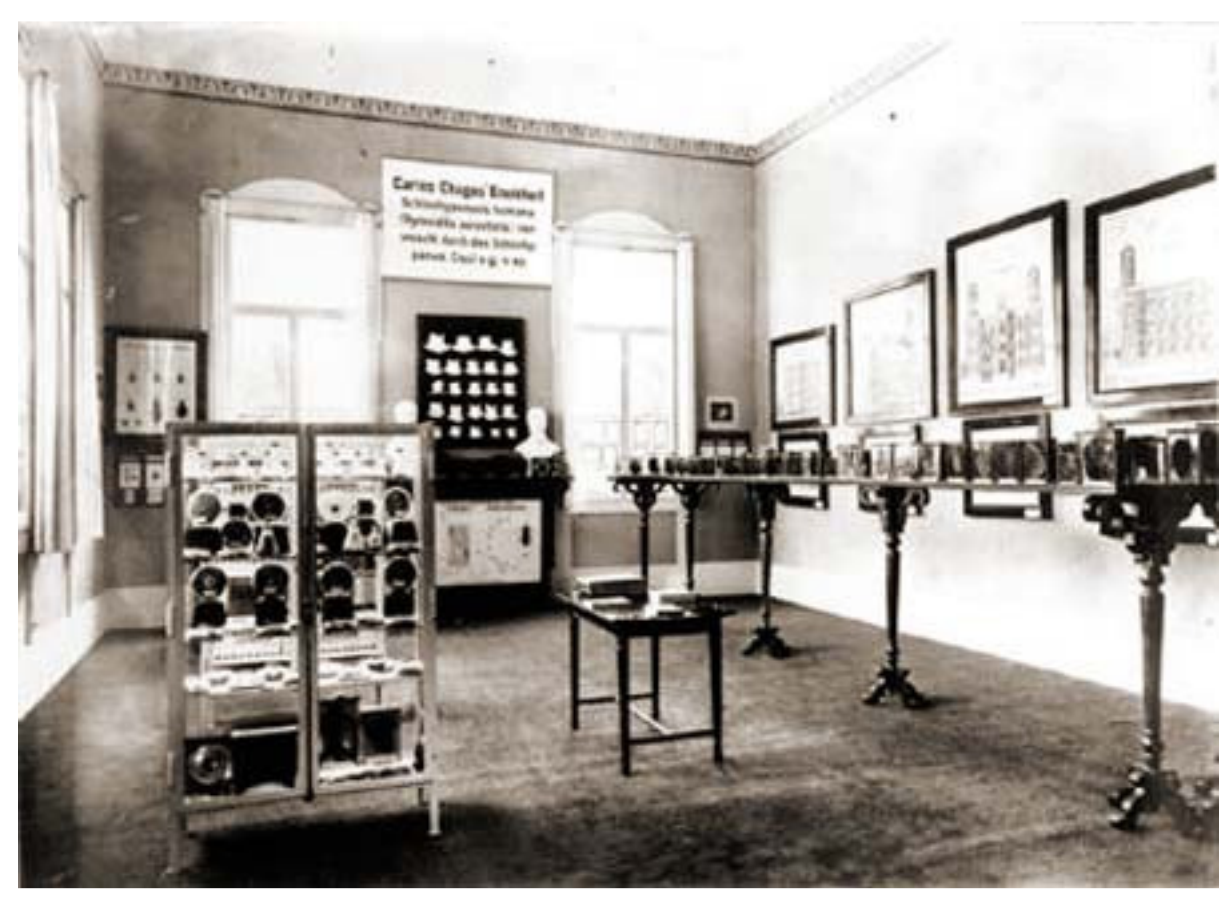

Figura 5. Sala de exposição brasileira na Exposição Internacional de Higiene, em Dresden (Alemanha), em 1911 (Acervo: Casa de Oswaldo Cruz).

Em comum a todas essas atividades de divulgação científica ocorridas na segunda metade do século XIX estavam a formação dos divulgadores e as temáticas predominantes. Em geral, os responsáveis por esses processos eram pessoas ligadas às ciências por sua prática profissional que estudavam em países europeus e tentavam adaptar os modelos externos de divulgação científica às suas realidades, geralmente centrando-se nos aspectos aplicados da ciência (MASSARANI; MOREIRA, 2004).

No caso das ciências naturais, por exemplo, devido à pequena presença de naturalistas no Novo Mundo e à importância das redes de comunicação transatlântica mantidas pelos estudantes dessas ciências, vê-se que os resultados de pesquisas se apresentavam por relatos de uma sociedade francesa ou inglesa, "agindo a sociedade local como correspondente da sociedade na metrópole europeia" (VESSURI; CAPEL, 1992). Observa-se ainda que, no período sob a vigência do regime monárquico, a criação de "instituições de caráter técnico, 
científico e cultural" começou a figurar entre as possibilidades de avanço científico no país, embora em número reduzido e restrita a áreas específicas (NAGAMINI, 2004a). Além disso, algumas das iniciativas de institucionalização e divulgação da ciência nessa época não tiveram continuidade, como a Sociedade Vellosiana de Ciências Naturais (1850-1855), a Sociedade Palestra Científica (fundada em 1856) ou a Revista Guanabara. Entretanto, muitas dessas iniciativas, ainda que não permanentes, foram incorporadas a outros espaços científicos, como o Instituto Histórico e Geográfico Brasileiro (FIGUEIRÔA, 1992).

Vê-se assim um período de implantação de iniciativas (embora nem sempre profícuas) imprescindível para formação, décadas mais tarde, de um quadro de pesquisa, ensino, divulgação e aplicação da ciência no país, que, segundo Alfonso-Goldfarb e Ferraz (2002), são parâmetros fundamentais para a institucionalização de qualquer área do conhecimento. Entretanto, é nesse ínterim, durante a virada do século XX, que é possível observar o certo refluxo nas ações de comunicação da ciência citado anteriormente. Como apontam Massarani e Moreira (2004, p. 52),

As conferências e os cursos populares declinaram, o envolvimento de cientistas e professores com essas atividades decresceu, assim como o número de revistas e artigos referentes à divulgação científica. Essa redução relativa não parece ser um fato isolado. Está correlacionada com a diminuição similar que ocorreu nas atividades de divulgação no contexto internacional.

Vale ressaltar que, embora os contextos nacionais e internacionais apresentassem uma diminuição de esforços na institucionalização da ciência, algumas iniciativas continuaram a ser observadas, principalmente no campo da saúde pública. É fácil entender esse processo: o Brasil apresentava sérios problemas de saneamento básico em seus principais núcleos urbanos - as cidades portuárias que se viam com um crescente aporte populacional. O governo estadual, bem como o federal, frente à necessidade premente de seus cidadãos em ter boas condições de saúde, buscou desenvolver ações, como a implantação de institutos de pesquisa e a construção de infra-estrutura adequada, bem como o desenvolvimento de planos de popularização dos conhecimentos científicos produzidos nessa empreitada. Vê-se aqui, a implantação do Instituto Butantan como uma ação pertencente a uma atividade maior, a de efetivação de uma política de saúde pública estadual. Entretanto, a criação do Butantan também se constituiu como uma atividade e isso fica evidente quando se analisa um outro objeto, uma outra necessidade. 


\subsection{OS SISTEMAS DE ATIVIDADE DE ENSINO/APRENDIZAGEM NO INSTITUTO BUTANTAN}

As ações iniciais do que mais tarde se constituiria como Instituto Butantan surgiram no final do século XIX, quando o Brasil estava fortemente marcado por uma política agroexportadora, baseada no cultivo do café, e o Estado de São Paulo aparecia como o principal centro econômico do país.

Nesse momento, a agricultura cafeeira foi a principal responsável não somente pelo desenvolvimento econômico do Brasil, mas também pelo surgimento de grupos sociais: uma nova elite, de caráter empresarial, bem como uma classe assalariada composta por imigrantes europeus (e posteriormente asiáticos) atraídos por uma propaganda de um novo país nãoescravocrata. Junto com esses, doenças até então pouco conhecidas no Brasil, como a peste, a cólera e a difteria, aportaram em Santos e outras cidades litorâneas. Numa tentativa de controle de epidemias e incorporando o ideário positivo evolucionista de renovação e multiplicação das instituições científicas, o governo estadual reorganizou seu serviço sanitário e, em 1892, criou o Instituto Bacteriológico.

Comandado em seu primeiro ano pelo biólogo francês Felix Le Dantec e, logo em seguida, por Adolpho Lutz, esse instituto foi incumbido de introduzir a epidemiologia pasteuriana no estado, o que se deu anos antes da criação do Instituto de Manguinhos, no Rio de Janeiro. A criação do Instituto Bacteriológico ${ }^{41}$ foi fundamental para o fortalecimento da pesquisa em saúde pública em São Paulo, pois, desde seu início propôs-se a "estudar a microbiologia em geral e, especialmente a etiologia das epidemias, endemias e epizootias mais freqüentes em nosso meio sanitário", além de realizar o "preparo, acondicionamento e remessa dos produtos necessários à vacinação preventiva e aplicações terapêuticas que se tornem indicadas às nossas condições higiênicas" (CAMARGO, 1984).

Assim, é possível compreender a inauguração de mais um instituto voltado para epidemiologia como uma ação constituinte da atividade de organização do sistema público de saúde. Entretanto, o aparecimento de uma doença (até então não diagnosticada), na passagem do século XIX para o XX, criou um novo desafio a ser enfrentado pelos governos estadual e federal no campo sanitário, originou uma nova situação problema. Em 1899, um surto de um "mal desconhecido" disseminava-se entre imigrantes e residentes da região portuária de

\footnotetext{
${ }^{41}$ Posteriormente, o Bacteriológico foi, juntamente com o Laboratório Bromatológico, transformado na instituição de pesquisa bastante reconhecida atualmente, o Instituto Adolfo Lutz. Entre os anos 1925 e 1931, fez parte do Instituto Butantan.
} 
Santos. Para evitar que uma epidemia assolasse o local, o Serviço Sanitário do Estado de São Paulo e a Inspetoria Geral de Higiene Pública (órgão do governo federal) incumbiram alguns cientistas de determinar o agente causador da doença e as medidas necessárias para seu controle.

Adolpho Lutz, diretor do Instituto Bacteriológico, e seu assistente, Vital Brazil, identificaram a doença como peste bubônica (FONSECA, 1954; BENCHIMOL; TEIXEIRA, 1993; NAGAMINI, 2004b) ${ }^{42}$. O resultado gerou dúvidas entre as autoridades públicas e os comerciantes locais, sendo Oswaldo Cruz, médico recém-cursado em Microbiologia pelo Instituto Pasteur, convidado a verificar o diagnóstico.

Confirmando os resultados iniciais, o parecer de Oswaldo Cruz também foi posto à prova, inclusive por clínicos locais, sendo Rodolpho Chapot Prévost, médico carioca, chamado para definir os diagnósticos oficiais. Somente com os resultados das análises de institutos europeus sobre culturas de micróbios enviadas pelo governo brasileiro, confirmando os resultados tupiniquins, é que medidas para a contenção da peste bubônica começaram a ser tomadas (BENCHIMOL; TEIXEIRA, 1993; NAGAMINI, 2004b).

As ações necessárias para o controle dessa iminente epidemia acabaram por determinar a criação de importantes centros de pesquisa e produção, culminando na formação de um verdadeiro complexo ligado à saúde nas cidades de São Paulo e Rio de Janeiro. Laboratórios para a produção do soro antipestoso foram instalados nessas cidades, a fim de prover uma quantidade suficiente de doses para uma demanda que o Instituto Pasteur, único produtor da época, não era capaz de suprir.

Dessa forma, a implantação de institutos respondeu a uma necessidade da sociedade: melhores condições de saúde objetivada na produção de conhecimento para o controle de epidemias, em especial a peste bubônica. Considerando-se que o motivo é, como afirma Leontiev (2004), o objeto que responde a uma necessidade determinada e que incita e dirige a atividade ou, como aponta Engeström (1999b, p. 380), "algo que se transforma em objeto da atividade quando encontra uma necessidade humana", constituindo-se como o "espaço problema" em que a atividade é moldada e transformada em resultado, observa-se um novo objeto e, portanto, uma nova atividade: sujeitos motivados a criar possibilidades de produção de conhecimento científico cujo resultado desejado é o controle de epidemias.

\footnotetext{
${ }^{42}$ A autoria do diagnóstico é controversa entre os autores. Para Flávio da Fonseca, foi Adolpho Lutz que reconheceu, em bases experimentais, a ocorrência de peste bubônica no Porto de Santos. Jaime Benchimol e Luiz Antonio Teixeira creditam a identificação do mal levantino a Vital Brazil. Já Marilda Nagamini coloca que os dois pesquisadores diagnosticaram a doença que afetava a cidade de Santos no final do século XIX.
} 
Na capital federal, foi instalado o Instituto Soroterápico do Rio de Janeiro, comandado pelo Barão de Pedro Afonso, então proprietário do Instituto Vacínico Municipal. A Fazenda de Manguinhos, localizada distante do centro da cidade para evitar alardes entre a população temerosa de possíveis contágios, foi a área escolhida para a instalação. Em pouco tempo, a instituição sairia da esfera municipal, passando para o controle federal com a denominação de Instituto Soroterápico Federal e, posteriormente, Instituto Oswaldo Cruz. Atualmente, está inclusa em um complexo de laboratórios e institutos localizados em diferentes estados brasileiros, denominado Fundação Oswaldo Cruz (FIOCRUZ).

Em São Paulo, foi criado um laboratório para a produção imediata do soro antipestoso de Yersen. Esse laboratório iniciou suas atividades em 1899, como uma seção do Instituto Bacteriológico, em uma área distante do centro urbano, a Fazenda Butantã (conhecida na época pela "excelência de [seus] produtos laticínios, vendidos por um depósito da rua Direita"43). Mas, já em 1901, separou-se do Bacteriológico, ganhou autonomia e passou a ser chamado oficialmente de Instituto Soroterápico do Estado de São Paulo ${ }^{44}$. Vital Brazil Mineiro da Campanha, primeiro diretor da instituição (de 1901 a 1919 e de 1924 a 1927), descreveu, posteriormente, as instalações iniciais do instituto como um

rancho aberto, ligado ao estábulo, no qual faziam a ordenha, [e que] foi rapidamente murado e adaptado aos fins de laboratório. Foi aí, nesse ambiente paupérrimo, onde o desconforto corria parelha, com a impropriedade das instalações, que tiveram início os primeiros trabalhos técnicos do Instituto Butantan ${ }^{45}$.

Dessa fala de Vital Brazil, ocorrida com um espaçamento de 40 anos em relação aos acontecimentos, algumas observações podem ser feitas. A primeira, e mais óbvia, é que as condições para a realização de suas tarefas eram bastante precárias. Nesse ambiente, Vital Brazil contou com 15 funcionários (01 ajudante, 01 administrador, 01 escriturário, 01 auxiliar, 06 serventes e 05 “camaradas" para plantação de forragens e outros serviços) ${ }^{46}$, para produzir o primeiro de vários lotes do soro antipestoso que seria responsável pelo controle da epidemia de peste no estado. Mas, por outro lado, reforça aquilo que Bertolli Filho (2005) trouxe como a "construção do mito de origem do Instituto Butantan". Para ele, Vital Brazil é colocado,

\footnotetext{
43 BRAZIL, V. Memória Histórica do Instituto Butantan. São Paulo: Elvino Pocai, 1941. 170p.

${ }^{44}$ Em 1918, o Instituto Serumtherápico do Estado de São Paulo passou a ser denominado de Instituto Serumtherapico de Butantan. Somente em 1925, com a reformulação do Serviço Sanitário do Estado, este instituto, juntamente com os institutos Bacteriológico e Vacinogênico, passaram a compor o Instituto Butantan. Neste texto, utilizaremos o termo Instituto Butantan ou a sigla IBu para quaisquer destes períodos.

${ }^{45}$ BRAZIL, V. Memória Histórica do Instituto Butantan. São Paulo: Elvino Pocai, 1941. p. 8.

${ }^{46}$ Relatório Anual do Instituto Butantan de 1901. Os relatórios anuais eram assinados por seu diretor em exercício. Na maioria deles, há relatórios parciais assinados pelos chefes de cada seção.
} 
pelo outro e por si mesmo, como o grande herói que, em condições paupérrimas, trouxe glórias à nação e a garantia de vida a milhares de pessoas, ignorando-se a importância do coletivo, das contradições e dos riscos inerentes à atividade como elementos fundamentais para uma construção histórica mais coesa. Esse posicionamento não tem como intenção desconsiderar o papel que esse pesquisador teve na ciência brasileira, mas sim pontuar que as ações desenvolvidas por ele estavam imersas em um caldo de interesses, posicionamentos, demandas, necessidades, que não somente o desenvolvimento da ciência e da saúde pública. Essa perspectiva de "mito de origem" é bastante profícua e pode ajudar na compreensão do desenvolvimento da atividade de ensino/aprendizagem na instituição.

Vital Brazil, além de condecorado como grande cientista, é também continuamente lembrado como o primeiro e grande divulgador e educador da instituição. Certamente, esta afirmação baseia-se em acontecimentos reconhecidos, mas é importante que seja analisada como atrelada a outro mito de origem, agora o da gênese da atividade de ensino/aprendizagem da instituição. Vale, portanto, trazer alguns dados para apoiar essa afirmação.

Em agosto de 1991, dois meses após a entrega do primeiro lote do soro antipestoso, Vital Brazil disponibilizou ainda o soro antiofídico. Essa produção não constava dos objetivos primeiros do laboratório, pautado para o combate à peste bubônica. Veio, logo no início, por um interesse pessoal de Vital Brazil que, mesmo antes de mudar-se para Botucatu, onde tinha uma clínica privada, estudava os efeitos das plantas e remédios populares contra o veneno das serpentes, atento ao número de acidentes que ocorriam entre agricultores ${ }^{47}$. Após a leitura de um artigo escrito por Calmette, pesquisador francês do Instituto Pasteur, Vital Brazil percebeu que o caminho para avanços significativos em suas pesquisas era a soroterapia, buscando então seu ingresso no Instituto Bacteriológico, onde contaria com melhores condições de infra-estrutura e recursos humanos. Foi como representante deste instituto que fora enviado a Santos para analisar as causas da imensa mortalidade de ratos que acontecia na cidade, em 1899, que teria levado ao surto de peste bubônica citado anteriormente.

Para o aprofundamento de seus estudos em soroterapia antiofídica, Vital Brazil necessitava de um acervo de animais, oriundos de diferentes localidades, para a extração de venenos e a realização de análises morfológicas. Entretanto, não contava com um corpo de funcionários adequados, em número e técnica, para garantir a entrada suficiente de animais para suas pesquisas. Além disso, o pesquisador era requerido, a todo momento, a comprovar a supremacia de seu soro em relação aos elixires e rezas disponíveis na época. Essa situação

\footnotetext{
${ }^{47}$ Brazil, V. Recordando... In: Memórias do Instituto Butantan, 14:IX-XII. 1940.
} 
pode ser observada em um trecho do Relatório Anual de 1902, em que Vital Brazil cita a carta enviada a ele pelo Dr. Marcondes Machado (médico de Tatuí que atendeu o caso de um agricultor picado por uma cascavel usando o soro antiofídico). Como conclusão, o médico escreve que "esta falta [o acidente ofídico] teve entretanto, a vantagem de convencer as pessoas que ainda duvidavam da efficacia de vosso serum, que ficou configurado o melhor meio de tratamento e o mais scientifico".

Necessitando de exemplares de serpentes e buscando uma maior penetração entre a população, iniciou um "plano de vulgarisação", como citado no Relatório Anual de 1902 pelo próprio Vital Brazil. Não há uma descrição clara desse plano, mas pelas ações registradas nos documentos oficiais neste e nos anos seguintes, percebe-se que havia uma preocupação do diretor e, possivelmente de seu corpo técnico, em estabelecer um vínculo entre o recém-criado instituto e a população paulista.

Uma ação nessa direção foi a implementação do sistema de permuta: o cidadão que trouxesse serpentes ao Instituto, levaria ampolas do soro antiofídico. Estava aberta também, para a visitação, a coleção inicial de serpentes ${ }^{48}$, para os interessados em observar mais de perto os temidos répteis. Seguiram ainda outras práticas educativas:

Obedecendo ao nosso plano de vulgarisação realisamos na Escola de Polythecnica de São Paulo duas conferencias acompanhadas de experiencias demonstradoras das actividades dos serums. Na Escola de Pharmacia d'esta Capital o Dr. Victor Godinho, fez uma lição sobre a serumtherapia, illustrando-a com demonstrações experimentaes da actividade dos serums anti-ophidicos preparados n'este Instituto ${ }^{49}$.

Como é observado, as principais estratégias de divulgação propagandística realizadas nesses primeiros anos prioritariamente vinculavam o Instituto aos estudos ofídicos. É provável que esse fato também esteja ligado aos interesses e dificuldades vivenciados por Vital Brazil. Como colocam Benchimol e Teixeira (1993), os soros antiofídicos, diferentemente dos antipestosos ou antidiftéricos, eram de uso individual. Enquanto o uso dos soros voltados para o controle de surtos epidêmicos era controlado por regras definidas pelos órgãos governamentais de saúde pública, o antiofídico era consumido preferencialmente pela população urbana, com a intermediação de clínicos e da rede hospitalar. Para criar uma demanda que viabilizasse a produção em escala, Vital Brazil viu a necessidade de fortalecer seu "plano de vulgarisação", por meio do que Temporão (1986 apud BENCHIMOL e

\footnotetext{
${ }^{48}$ Foram esses primeiros animais fixados em álcool que deram origem à atual Coleção Herpetológica "Alphonse Richard Hoge".

49 Relatório Anual de 1902.
} 
TEIXEIRA, 1993, p. 81) chamou de "propaganda popular". Nessa visão, Vital Brazil teria ido além da "propaganda ética" (que tem como único público-alvo a classe médica), priorizando os consumidores finais de seu produto terapêutico: a população rural.

Segundo Benchimol e Teixeira (1993), Vital Brazil engajou-se pessoalmente na divulgação dos resultados de seus estudos em anúncios de jornais, em boletins que acompanhavam os produtos terapêuticos ou em relatórios para o Serviço Sanitário. Em uma segunda estratégia, esforçou-se em demonstrar a ineficiência dos produtos alternativos disponíveis no mercado, que possuíam grande aceitação popular, como Salvador (BENCHIMOL e TEIXEIRA, 1993), a Vegetalina Imperial $^{50}$ e, provavelmente, o famoso Específico Pessoa $^{51}$ (Figura 6).

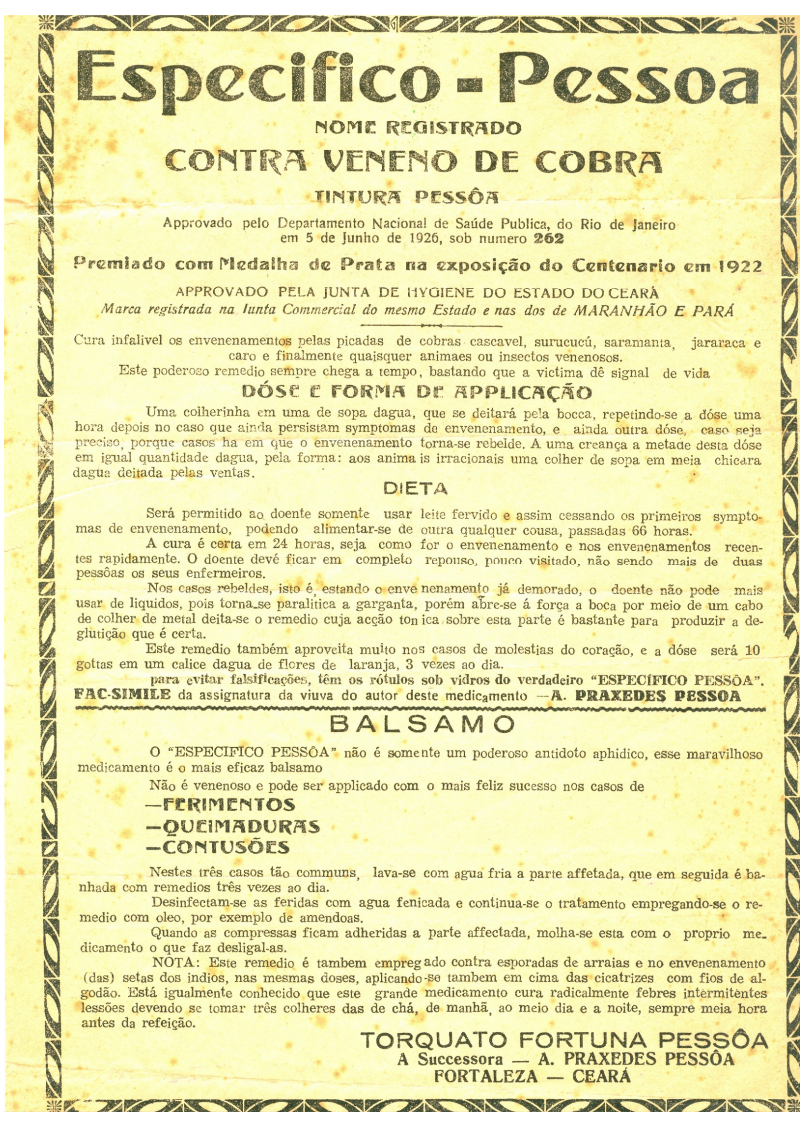

Figura 6. Material de divulgação do fármaco comercial Específico Pessoa utilizado popularmente para o tratamento de acidentes ofídicos (Acervo Pessoal de Henrique Moises Canter).

\footnotetext{
${ }^{50}$ Conforme imagem do Correio Paulistano de 1888, reproduzida no livro "100 anos de Butantan", organizado por Henrique Moisés Canter, em 2000, para comemoração do centenário da instituição.

${ }^{51}$ Pesquisas atuais demonstram a capacidade de proteção contra a ação do veneno de cinco espécies de serpentes por princípios ativos sintetizados em laboratório a partir de duas espécies de plantas presentes nessas 'garrafadas' (Boletim da FAPERJ, 13/10/2005).
} 
Outro elemento importante é que, nos primeiros anos do Instituto Butantan, vê-se a produção concomitante de soros (antipestosos, antiofídicos e, a partir de 1906, antidiftérico) e vacinas (antipestosas), enviados para diferentes estados brasileiros, ou ainda para a Inglaterra e Estados Unidos. No Relatório Anual de 1902, entende-se numericamente essa produção: 1130 ampolas de soro antipestoso, 150 ampolas de vacina antipestosa, 75 de soro anticrotálico (contra veneno de cascavel), 67 de antibotrópico (diferentes espécies de 'jararaca') e 475 de antiofídico (misto). Enquanto a produção e a pesquisa do Instituto caminhavam tanto pela área da epidemiologia quanto pelo combate ao ofidismo, a comunicação com o público acabou enfatizando a segunda linha. Embora houvesse pesquisas desenvolvidas por Dorival de Camargo e Bruno Rangel Pestana sobre o tifo, o tétano, a tuberculose e outras doenças, Vital Brazil dedicava-se prioritariamente aos estudos sobre ação de venenos ofídicos. E eram essas pesquisas as prioritariamente divulgadas.

Esses dados fornecem elementos para a compreensão de uma possível atividade de ensino/aprendizagem ocorrida inicialmente no Instituto Butantan. Vê-se que as primeiras ações de divulgação e educação faziam parte de uma atividade outra que não a de ensino: eram constituintes da atividade de pesquisa de Vital Brazil e sua equipe. Essa ideia baseia-se em um dos elementos chaves da Teoria da Atividade: o motivo.

Para Leontiev (LEONTIEV, 2004, p. 315), como já mencionado, a atividade corresponde aos "processos que são psicologicamente determinados pelo fato de aquilo para que tendem no seu conjunto (o seu objeto) coincidir sempre com o elemento objetivo que incita o paciente a uma dada atividade, isto é, com o motivo". Tomando-se como base os dados citados anteriormente (interesse de Vital Brazil pela soroterapia, uso da "propaganda popular", combate a produtos terapêuticos alternativos, prevalência de divulgação de um determinado tipo de pesquisa), é possível supor que os motivos de Vital Brazil para realizar os processos de divulgação e educação estavam relacionados à obtenção de serpentes para sua pesquisa e à aceitação pública de seus resultados (o que garantiria a continuidade da linha de pesquisa implantada por ele). Ao se considerar esses motivos, as ações educativas do pesquisador estavam contextualizadas na atividade de pesquisa de Vital Brazil. O ensino não se constituiria então como uma atividade, mas sim uma ação integrante da atividade de pesquisa de Vital Brazil e seu grupo.

Entretanto, vale lembrar que os níveis hierárquicos atividade/ação/operação não são fixos e que uma ação pode se transformar em uma nova atividade. $\mathrm{O}$ motivo da atividade 
pode se deslocar e "tornar-se o objeto (o fim) do ato". Leontiev (2004, p. 317) exemplifica esse processo:

Suponhamos que um aluno da primeira não consegue entregar-se aos seus deveres. Tenta por todos os meios afastar o momento em que terá que fazêlos, e ainda mal começou já se distrai com outra coisa. Acaso compreende ele ou saberá que lhe é preciso preparar as lições, que senão terá uma má nota, que isso entristecerá os pais, em resumo, que aprender é uma obrigação para ele, que é o seu dever, que, sem isso, não poderá tornar-se realmente útil à sua pátria etc.? Por certo que a criança normalmente desenvolvida sabe tudo isso, e ainda não é suficiente para levar a entregar-se ao trabalho escolar.

Suponhamos agora que se diz à criança: enquanto não fizer os teus deveres não vais brincar. Esta observação faz efeito e a criança entrega-se ao trabalho.

Neste caso, a situação é portanto, a seguinte: a criança quer ter uma boa nota e também fazer o que deve. Não há dúvida nenhuma que para sua consciência, estes motivos existem. Todavia, são psicologicamente ineficientes para ela: o motivo que age verdadeiramente é o de obter a possibilidade de ir brincar.

Chamaremos os motivos do primeiro tipo motivos "apenas compreendidos", e aos do segundo tipo: motivos "que agem realmente". Feita esta distinção podemos enunciar a seguinte proposição: os "motivos apenas compreendidos" transformam-se, em determinadas condições em motivos eficientes. É assim que nascem os novos motivos e, por consequência, novos tipos de atividade. [...]

Como se faz a mudança de motivo? A resposta é simples. Em certas condições, o resultado da ação conta mais que o motivo que realmente suscita a ação.

É bem provável que Vital Brazil tivesse a compreensão da importância da divulgação e da educação para a formação do sujeito, que soubesse que esses processos poderiam ajudar na prevenção de acidentes ou no atendimento médico. Mas, é também provável, que esses motivos se apresentassem como "apenas compreendidos" e que os motivos "realmente eficazes" para oferecer cursos e conferências públicas e elaborar um plano de vulgarização fossem a obtenção de animais peçonhentos e o reconhecimento de suas pesquisas junto a diferentes públicos.

Na segunda década de atividades, já se percebe os resultados de seu plano de vulgarização: tanto a entrada de um número crescente de animais que permitiam a extração de venenos para pesquisa e produção como a aceitação pública dos produtos antipeçonhentos fortaleceram e justificaram os estudos de Vital Brazil sobre as serpentes. A produção de soros e vacinas continuou sempre como uma das funções sociais do Instituto ${ }^{52}$, mas as pesquisas

\footnotetext{
${ }^{52}$ A exceção é a produção do soro antipestoso, que já no Relatório de 1906 é citado como tendo baixa saída devido à diminuição das manifestações epidêmicas. Já o soro antiofídico tem sua produção aumentada
} 
nas áreas de sorologia, microbiologia e imunologia parecerem ter sido colocadas em um segundo plano. Enquanto os estudos com animais peçonhentos, incluindo agora os aracnídeos, eram divulgados em periódicos científicos, conferências públicas e cursos, as demais linhas não tiveram e mesma visibilidade ${ }^{53}$. Dentro do meio científico, o Butantan aparecia para seus pares como instituição fortemente vinculada ao ofidismo. O Instituto chegou a receber, em 1909, medalha de ouro na Exposição Internacional de Higiene, no Rio de Janeiro, anexa ao IV Congresso Médico Latino-Americano ${ }^{54}$. Esse prestígio tornou-se ainda maior quando, em 1912, Vital Brazil "venceu" a disputa travada com Calmette ${ }^{55}$, dando ao Instituto uma projeção internacional na pesquisa soroterápica antiofídica. Assim, tanto para cientistas como para leigos, a imagem do Butantan foi sendo atrelada aos animais venenosos de interesse médico. As demais linhas de pesquisa raramente foram divulgadas nesses anos iniciais da instituição.

Como coloca Cedro (2008, p. 188), baseado em Serra $(2001)^{56}$ :

O ser humano, durante toda a sua existência, experimenta uma série de desejos, sentimentos, emoções, aspirações e propósitos. Estes elementos dependendo das condições objetivas adequadas podem impelir e dirigir suas ações e proporcionar a ele a satisfação de suas necessidades. Neste sentido, a sua vida cotidiana é marcada pela existência de objetos, ideais ou reais, que indicam a satisfação das suas necessidades e que o induzem a agir. Contudo, por causa das condições que caracterizam a atividade humana, a todo momento novas situações externas, circunstâncias temporais, insatisfações, desejos, vontades e projetos emergem e acabam redirecionando a atividade e estabelecendo novos graus de intensidade para a sua execução por parte do indivíduo.

continuamente, garantida, em parte, pela maior quantidade de veneno conseguida pela chegada de serpentes ao Instituto.

${ }^{53}$ É necessário um aprofundamento nesse ponto: pelos relatórios anuais não é possível saber se são citados todos os artigos publicados em cada ano. Para isso, devem ser analisados os principais periódicos em que pesquisadores do Instituto Butantan publicavam nesse período, como a Revista Médica de São Paulo e os Anais Paulistas de Medicina e Cirurgia. Com a criação do "Memórias do Instituto Butantan", em 1918, as publicações desses pesquisadores tornaram-se mais constantes.

${ }^{54}$ Essas Exposições Internacionais de Higiene realizavam-se anexas aos congressos médicos latino-americanos que ocorreram em diferentes países sul-americanos, no início do século XX. Esses congressos, além de ajudaram em um direcionamento da ciência e tecnologia no país, principalmente para a área médica, funcionaram como importante canal de diálogo entre as demandas de ordem sanitária e os poderes públicos (ALMEIDA, 2003).

${ }^{55}$ Para Albert Calmette, imunologista francês que criou a vacina BCG (Bacilo Calmette-Guérin), o soro que produziu a partir do veneno de Naja naja era eficaz para acidentes com qualquer espécie de cobra. Entretanto, os estudos de Vital Brazil demonstraram que havia uma especificidade dos soros antiofídicos, sendo necessária a produção de soros diferentes para acidentes com espécies diferentes. Em 1912, o suíço Maurice Arthus, confirmou as diferenças nas composições e ações dos diferentes venenos de serpentes.

${ }^{56}$ SERRA, D. Teoria de la motivación y practica profesional. Habana: editorial pueblo y educacion, 2001. 
Frente a esse movimento inerente à atividade humana, é possível supor, com base nos dados apresentados, que os resultados obtidos por Vital Brazil a partir das ações de divulgação e educação realizadas, como o fortalecimento de sua linha de pesquisa, mas, principalmente, a procura crescente dos cidadãos de todo o país em busca de informações sobre seus conhecimentos e produtos e a projeção que o Instituto Butantan teve frente a diferentes públicos, possam ter transformado os motivos apenas compreendidos em motivos realmente eficazes. Nesse caso, é possível falar em um início de uma estruturação da atividade de ensino/aprendizagem já nas primeiras décadas da instituição.

Tem-se aqui uma questão bastante relevante: se, por um lado, a pesquisa científica realizada pelo Instituto Butantan foi importante para seu público devido ao controle do surto pestoso e à diminuição da mortalidade por acidentes peçonhentos, por outro, esse público, por suas ofertas (como a entrega de animais ao Instituto) e demandas (como o interesse por animais venenosos em um país essencialmente agrário), foi fundamental na institucionalização da pesquisa científica desenvolvida pelo Butantan, fortalecendo e justificando as linhas priorizadas por Vital Brazil.

Vale ressaltar que essa construção inicial de seu discurso de divulgação influenciou boa parte das estratégias comunicativas adotadas pela instituição nas décadas seguintes. Como exposto adiante, o Instituto Butantan desenvolveu uma série de atividades de divulgação e educação em ciências, condizente com as estratégias desenvolvidas nos contextos nacional e internacional, mas preferencialmente focada em uma questão específica da saúde pública: os animais peçonhentos.

\subsubsection{A diversificação nas estratégias de divulgação científica e educação em saúde do Instituto Butantan}

As primeiras décadas do século XX trouxeram modificações para a ciência (e sua comunicação) em um Brasil que, até então, estava voltado para as ciências aplicadas, numa tentativa de desenvolvimento tecnológico de uma nova república. Nesse período, a ação de um grupo constituído por cientistas, professores, médicos e profissionais liberais ligados a instituições científicas (que tinham como um de seus motivos o desenvolvimento da pesquisa no Brasil) foi fundamental para a retomada da educação em ciências fora da escola, na década de 1920 (MASSARANI, 1998). Henrique Morize, Edgard Roquette-Pinto, Manoel Amoroso Costa, são alguns exemplos de profissionais envolvidos em um movimento organizado que 
buscou institucionalizar a pesquisa no Brasil, definindo um caminho para as investigações em temas não necessariamente aplicados. Surgem assim várias ações que foram o início de uma outra abordagem para as ciências no país: o desenvolvimento da pesquisa básica e um processo de extroversão da ciência mais amplo do que aquele do final do XIX. Vemos ainda, um início de um associativismo científico mais estruturado no Brasil, bem como de um investimento político na implementação de cursos superiores, com a formação de sociedades e faculdades que contribuíram para a institucionalização da pesquisa científica. Essas instituições estabelecidas tornaram-se importantes agentes de comunicação da ciência no país (MOREIRA; MASSRANI, 2002).

A década de 1920 foi importante também para o Instituto Butantan. A partir dessa época, apesar de crises pontuais decorrentes de má organização interna ou de eventos externos (como a quebra da bolsa de Nova Iorque, em 1929, as revoltas no estado, em 1924 e 1932, ou a II Guerra Mundial) ${ }^{57}$, vê-se uma crescente diversificação não somente nas linhas de pesquisa desenvolvidas pela instituição (com o fortalecimento visível de muitas delas), como também nas estratégias de ensino e divulgação realizadas (Apêndice 1).

Em relação às atividades de pesquisa, observa-se essa variação temática analisando o periódico "Memórias do Instituto Butantan", publicado a partir de $1918^{58}$. Sabe-se que o número de artigos publicados não é o único ou o mais eficiente indicador da qualidade da pesquisa realizada por uma instituição, mas pode fornecer um parâmetro de análise, pois representa a variação de atividade de pesquisa em determinadas áreas. Embora alguns dos artigos publicados nas áreas em crescimento, como parasitologia, genética ou farmacologia, ainda focassem os animais venenosos, a maioria versava sobre outros temas de estudo. As Tabelas 03 e 04 ilustram as publicações realizadas em diferentes áreas de pesquisa entre 1918 e 1989 no periódico da instituição.

\footnotetext{
${ }^{57}$ Esses momentos têm uma peculiaridade em relação à produção do instituto: ao mesmo tempo em que havia um aumento na produção de soros e vacinas, para suprir a maior demanda em períodos de guerra ou revoluções, ocorria também uma crise financeira e administrativa pois a escassez de produtos no mercado necessários para as atividades do instituto era inevitável.

${ }^{58}$ Esse periódico não representa a totalidade das pesquisas publicadas na instituição, mas oferece uma boa fonte documental, já que parte importante das publicações realizadas era feita nessa revista: em alguns relatórios anuais havia uma preocupação em citar o número total de trabalhos publicados e o número de trabalhos publicados no "Memórias do Instituto Butantan". Em geral, metade da produção era publicada nessa revista. Vale ressaltar que a grande maioria das publicações foi feita por pesquisadores do Instituto Butantan.
} 
Tabela 3. Número de artigos publicados no periódico "Memórias do Instituto Butantan", entre os anos de 1918 e 1969, separados por temas. Fonte: Remissive List of Papers Published in "Memórias do Instituto Butantan"- volumes 1 to 33 (1918-1966). Mem. Inst. But., 34:209-249, 1969.

\begin{tabular}{|c|c|c|c|c|c|c|c|}
\hline Tema/década & 1910 & 1920 & 1930 & 1940 & 1950 & 1960 & Total \\
\hline Parasitologia & 3 & 2 & 64 & 16 & 31 & 7 & 123 \\
\hline Ofídios - sistemática & 1 & 7 & 25 & 19 & 27 & 18 & 97 \\
\hline Venenos ofídicos & 0 & 1 & 13 & 8 & 8 & 44 & 74 \\
\hline Aracnídeos e artrópodos-sistemática & 0 & 2 & 15 & 21 & 10 & 15 & 63 \\
\hline Endocrinologia & 0 & 0 & 13 & 30 & 3 & 3 & 49 \\
\hline Ofídios - biologia & 1 & 0 & 11 & 7 & 8 & 6 & 33 \\
\hline Bacteriologia & 0 & 3 & 8 & 17 & 2 & 0 & 30 \\
\hline Immunologia - soros & 1 & 0 & 5 & 6 & 3 & 13 & 28 \\
\hline Immunologia & 1 & 6 & 17 & 4 & 0 & 0 & 28 \\
\hline Virologia - vírus & 0 & 0 & 22 & 2 & 2 & 0 & 26 \\
\hline Genética-animal & 0 & 0 & 14 & 3 & 0 & 6 & 23 \\
\hline Virologia - riquetsia & 0 & 0 & 14 & 8 & 0 & 1 & 23 \\
\hline Hematologia & 0 & 0 & 0 & 7 & 10 & 5 & 22 \\
\hline Venenos diversos & 0 & 0 & 1 & 2 & 1 & 17 & 21 \\
\hline Aracnídeos e artrópodos-biologia & 0 & 0 & 0 & 1 & 4 & 15 & 20 \\
\hline Venenos aranhas & 0 & 2 & 0 & 0 & 5 & 13 & 20 \\
\hline Botânica médica & 1 & 0 & 5 & 2 & 0 & 3 & 11 \\
\hline Venenos anfíbios & 0 & 2 & 2 & 0 & 0 & 7 & 11 \\
\hline Química & 0 & 0 & 0 & 7 & 3 & 0 & 10 \\
\hline Virologia - microscopia eletrônica & 0 & 0 & 0 & 0 & 5 & 5 & 10 \\
\hline Venenos & - & - & - & - & - & 9 & 9 \\
\hline Farmacologia & 0 & 0 & 0 & 6 & 1 & 1 & 8 \\
\hline Diversos & 0 & 1 & 2 & 0 & 1 & 3 & 7 \\
\hline Batráquios & 0 & 1 & 0 & 2 & 1 & 0 & 4 \\
\hline Fisiologia & 0 & 0 & 1 & 1 & 2 & 0 & 4 \\
\hline Patologia & & & & & & 3 & 3 \\
\hline
\end{tabular}


Tabela 4. Número de artigos publicados no periódico "Memórias do Instituto Butantan", entre os anos de 1970 e 1989, separados por temas. Fonte: Lista Remissiva dos Trabalhos Publicados nas "Memórias do Instituto Butantan"volumes 34 a 38 (1969-1974). Mem. Inst. But., 39:239-245, 1975; volumes 39 a 46 (1975-1982), Mem. Inst. But., 47:205-216, 1983 e volumes 47 a 51 (1983-1989), Mem. Inst. But., 52:107-111, 1990.

\begin{tabular}{|c|c|c|}
\hline Tema/década & 1970 & 1980 \\
\hline Ofídios - sistemática & 30 & 15 \\
\hline Parasitologia & 22 & 4 \\
\hline Aracnídeos / artrópodos - sistemática & 12 & 9 \\
\hline Ofídios - biologia & 13 & 6 \\
\hline Patologia & 16 & 1 \\
\hline Imunologia - soros & 6 & 9 \\
\hline Anatomia patológica & 10 & 3 \\
\hline Envenenamento ofídico & 3 & 5 \\
\hline Microscopia eletrônica & 7 & 0 \\
\hline Química & 4 & 3 \\
\hline Venenos ofídicos & 6 & 0 \\
\hline Envenenamento aracnídeo & 2 & 3 \\
\hline Imunologia & 3 & 2 \\
\hline Obituário & 2 & 2 \\
\hline Aracnídeos e artrópodos - biologia & 3 & 0 \\
\hline Entomologia médica & 1 & 2 \\
\hline Genética & 3 & 0 \\
\hline Biografia & 2 & 0 \\
\hline História & 1 & 1 \\
\hline Instituto Butantan - história & 0 & 2 \\
\hline Mamíferos - resgate de fauna & 1 & 1 \\
\hline Ofídios - resgate de fauna & 1 & 1 \\
\hline Diversos & 2 & 0 \\
\hline Bibliografia - trabalhos & 1 & 0 \\
\hline Educação & 1 & 0 \\
\hline Invertebrados marinhos brasileiros & 0 & 1 \\
\hline Venenos aracnídeos & 0 & 1 \\
\hline Total & 152 & 71 \\
\hline
\end{tabular}

Pode-se observar a partir da análise dos artigos publicados e dos relatórios anuais que, durante as décadas de 1920 a 1960, o Instituto Butantan ampliou suas atividades, contou com a vinda de pesquisadores estrangeiros e aumentou sua produção, embora ainda de forma pouco organizada e dependente de ações governamentais. Somente em 1969, com a reestruturação interna e externa iniciada no ano anterior, vê-se um redirecionamento das ações institucionais, promovendo uma maior autonomia.

Assim como na pesquisa, observa-se efeito semelhante em relação à divulgação científica e à educação em ciências desenvolvidas pela instituição: embora o número de 
estratégias aumentasse durante o século XX (Apêndice 1), ainda eram tímidas as ações planejadas, em longo prazo, para esse fim. Com exceção das conferências públicas, as demais práticas, como os cursos de curta e longa duração, a escola rural, os impressos e pôsteres, as bulas, as publicações em revistas e jornais, o atendimento no parque, ocorriam pontualmente, sem continuidade intencional, ao menos enquanto registro nos relatórios anuais.

Somente a partir da década de 1950, esses relatórios passaram a apresentar um item estruturado identificado como "atividades didáticas": eram relatados os cursos, as palestras e as conferências ocorridos em cada ano. Em 1958, muitas das seções do Instituto também começam a registrar, junto com suas atividades científicas, as suas atividades de rotina, comunicações e participações em congressos.

Vê-se que as décadas de 20 a 50 do século passado corresponderam para o ensino no Instituto Butantan a um período de aquisição, pela instituição, de conteúdos, pressupostos e modos de se realizar os processos de divulgação e de educação concomitante com a criação de novas estratégias e a entrada de novos sujeitos. As ações e a atividade inicialmente propostas por Vital Brazil foram transformadas por outros sujeitos ativos, com outros motivos e necessidades. Assim, ao mesmo tempo em que ocorre o processo de internalização de conteúdos e modos, ocorre ainda um processo criativo, de externalização. Nesse movimento, surgem contradições inerentes à atividade e são essas contradições que a mantém em movimento. Vê-se, na década de 1950, o surgimento da necessidade de organização das práticas até então realizadas e, alguns anos depois, o início de uma preocupação com os públicos da instituição, procurando identificar suas principais demandas e características.

Os movimentos observados na primeira metade do século XX na atividade de ensino/aprendizagem do Instituto Butantan são mais facilmente compreendidos ao serem colocados sob à luz do já citado conceito de ciclos expansivos (expansive cycles) sugerido por Engeström (1987, 1999a,b). Para o autor, uma ferramenta chave para a análise histórica é sua periodização, uma divisão do fluxo de eventos em períodos com suas próprias características significativas. Partindo das propostas de Zerubavel $(1979)^{59}$, para quem as organizações apresentam, ao longo do tempo, camadas de estruturas cíclicas, repetitivas, Engeström avança na ideia de que os ciclos não são sempre repetitivos. Eles podem também levar à emergência de novas estruturas, baseadas nas já existentes. Para tais estruturas temporais irreversíveis, deu o nome de ciclos expansivos, relacionado-os ao movimento de uma espiral.

\footnotetext{
${ }^{59}$ Zerubavel, E. Patterns of time in hospital life. Chicago: University of Chicago Press. 1979.
} 
O ciclo expansivo é um processo de desenvolvimento que contem tanto a face de internalização quanto de externalização:

A nova estrutura da atividade não emerge do nada. Ela requer uma análise reflexiva do sistema de atividade existente - é necessário aprender a saber e compreender o que se quer transcender. E isso requer apropriação reflexiva de ferramentas e modelos culturalmente avançados que ofereçam formas de sair das contradições internas. Entretanto, estas formas de internalização ou apropriação não são suficientes para a emergência de uma nova estrutura. Enquanto o ciclo avança, o design atual e a implantação de um novo modelo para a atividade ganha seu momento: a externalização começa a dominar (ENGESTRÖM, 1999a, p. 33, tradução nossa).

Engeström (1987) relacionou esse movimento expansivo de internalização e externalização ao processo de aprendizagem. Assim, recorrentemente, utiliza o termo ciclo de aprendizagem expansiva. Para ele, a aprendizagem expansiva é baseada na dialética da ascensão do abstrato ao concreto, um método de se capturar a essência de um objeto ao se identificar e reproduzir a lógica de seu desenvolvimento, de sua formação histórica dada a partir da emergência e da resolução de suas contradições internas. Baseado em Davidov, Engeström (1999b, p. 382, tradução nossa) explica o movimento de ascensão ao concreto:

Um novo conceito teórico é inicialmente produzido na forma de uma relação explanatória abstrata, simples, uma célula germinal. Essa abstração inicial é enriquecida passo a passo e transformada em um sistema concreto de múltiplas e constantes manifestações em desenvolvimento. Em um ciclo de aprendizagem expansiva, a ideia inicial simples é transformada em um objeto complexo, uma nova forma de prática. Ao mesmo tempo, o ciclo produz novos conceitos teóricos - práticas teoricamente apropriadas concretos em riqueza sistêmica e multiplicidade de manifestações.

A ascensão ao concreto é alcançada a partir de ações específicas epistêmicas ou de aprendizagem (questionamento, análise, modelagem, implementação de modelo, reflexão e consolidação). Essas ações, orquestradas, formam um ciclo expansivo, como já mencionado, na forma de uma espiral. Um ciclo expansivo começa com sujeitos individuais questionando as práticas vigentes e aceitas e esse questionamento gradualmente se expande para uma coletividade, seja ela um movimento ou uma instituição. Esse ciclo de aprendizagem expansiva pode ser utilizado tanto para uma análise de transformações em larga escala de um sistema de atividade (p. e., no nível macro, institucional, ao longo de anos), como, com ressalvas, em escalas menores (nível micro, individual, em ciclos que duram minutos ou horas).

Sua sugestão é a de que os ciclos expansivos sejam compreendidos e analisados a partir da formação e da resolução das tensões e contradições internas de um sistema de 
atividade complexo que inclui objetos, artefatos mediadores e os pontos de vista dos participantes. O olhar para as tensões e contradições é importante pois "a trajetória de um sistema de atividade movendo-se ao longo de um ciclo expansivo parece atravessar fases de condições distantes de equilíbrio" (Engeström, 1999a, p. 33, tradução nossa).

Assim, o plano de vulgarização proposto por Vital Brazil pode ser visto como um primeiro conceito teórico, trazido ao Instituto de forma abstrata que serviu como elemento norteador para o desenvolvimento das estratégias para a divulgação e educação. Provavelmente, esse conceito, ao ser vivenciado, sofreu transformações por outros sujeitos partícipes da atividade de ensino/aprendizagem. Ao agirem, ao implantarem as características do plano de divulgação, os novos sujeitos responsáveis pela ações (como Florêncio Gomes), expandiram esse conceito, criaram novas formas de práticas. Frente aos numerosos problemas/objetos da atividade dos sujeitos, como a mortalidade por animais peçonhentos, a validação de linhas de pesquisa, a substituição dos fármacos alternativos pelo soro antiofídico, entre tantos outros, os novos divulgadores do instituto desenvolveram outros modos de comunicação com o público, em microciclos de atividade, tendo agora o conceito de "plano de vulgarização" como ferramenta, como um artefato mediador (cf. ENGESTRÖM, 1999b). As práticas iniciais, como os cursos e as conferências científicas, a permuta de soros por animais ou a "propaganda popular" foram gradativamente dividindo terreno com as novas práticas elaboradas (p. e., a produção de materiais impressos, a abertura do parque da instituição para visitação pública, as exposições externas, entre outras). O processo de externalização do conceito de "plano de vulgarização" aumenta, enquanto sua internalização diminui, em um movimento, que, no nível do sistema de atividade coletiva, pode ser visto como um equivalente, no nível individual, à Zona de Desenvolvimento Imediato de Vigotski (2007).

Nesse movimento, tensões e contradições são inerentes e facilmente observáveis. A falta de uma organização institucional em relação à divulgação e à educação aparece como um elemento que traz uma nova necessidade, a de se estruturar um setor educativo especialmente voltado ao público crescente que recorre ao Butantan. Essa nova necessidade motiva uma nova atividade de ensino/aprendizagem, baseada na já existente, mas com outros elementos. Ao olhar para o público, o foco nos animais peçonhentos, a ênfase na ciência já não é o conteúdo principal da atividade. É possível perceber um novo ciclo surgindo, pois a partir da década de 60 a divulgação científica e a educação em ciências no Instituto passaram a contar com planos de ação com definição de objetivos claros, estratégias direcionadas a 
diferentes públicos e elaboração de indicadores de avaliação. Um novo sujeito, representante desse ciclo que se inicia, é Rosa Pimont ${ }^{60}$.

Em 1962, o Instituto Butantan teve sua área educativa estruturada como Seção de Cursos Técnicos e Especializados e foi a pedagoga Rosa Pimont, a até então "assistente técnica de cursos" ${ }^{\prime 61}$, quem assumiu sua coordenação. Seis anos mais tarde, o Instituto passou por uma grande reforma estrutural e, em seguida, foram criadas as Divisões (Biologia, Patologia, Extensão Cultural, entre outras) ${ }^{62}$. A Divisão de Extensão Cultural, embora oficialmente estruturada, permaneceu por dez anos sem direção ${ }^{63}$ e, somente em 1981, Rosa Pimont assumiu sua chefia (ficando no cargo até sua morte, dois anos depois). Nas quase três décadas em que atuou no Instituto ${ }^{64}$, embora ainda persistisse certa ênfase na educação para a prevenção de acidentes com animais peçonhentos, observa-se uma crucial mudança na área educativa do Instituto.

Rosa Pimont foi responsável por uma transformação na atividade de ensino/aprendizagem do Butantan: com ela, o instituto passou a ter um plano de ação na área, com objetivos definidos, estratégias e indicadores de avaliação. Nos relatórios assinados pela pedagoga, vê-se pela primeira vez uma maior descrição do público atendido pelo Instituto (demonstrando o início de uma mudança de ênfase do conteúdo científico para o público), bem como uma diferenciação clara de ações para cada um deles. Rosa Pimont elaborou conteúdos programáticos para alunos de $1^{\circ}$ e $2^{\circ}$ graus (procurando relacioná-los com as questões educacionais da época, como um ensino de $2^{\circ}$ grau voltado para a

\footnotetext{
${ }^{60}$ Rosa Pavone Pimont, paulistana nascida em 1930, era pedagoga com especialização em Bacteriologia e Imunologia (1959), Orientação Educativa (1968) e Educação em Saúde Pública (1971) e doutora em Educação (1972). Ingressou no Instituto Butantan em 1954, como técnica do Laboratório de Anaeróbios (Seção de Imunologia) e, em 1961, tornou-se assistente técnica de cursos e assessora da Diretoria Técnica. Nesse cargo, organizou uma série de cursos de especialização e divulgação. Em 1963, tornou-se chefe da Seção de Cursos Técnicos e Especializados (posteriormente Seção de Cursos) e, em 1981, Diretora da Divisão Cultural. Atuou no MEC (Consultora Individual na Área da Saúde), no Ministério da Saúde (Diretora da Divisão de Educação Sanitária) e no CNPq (Técnica em Desenvolvimento Científico, Coordenadora do Programa Integrado de Ecologia Humana e Representante do órgão na UNESCO). Faleceu em 1983, em acidente em Belém do Pará, quando participava da reunião anual da SBPC (RIZZO, 1983/1984). Além disso, Rosa Pimont também foi pioneira na atividade de Pesquisa em Educação, linha até então inexistente do Instituto. Publicou mais de 30 artigos na área e participou de mais de 60 congressos científicos. Entre seus artigos, encontram-se: "Contribuição do Instituto Butantan para a formação de especialistas no campo da Biologia", de 1964, e "A educação em saúde: conceitos, definições e objetivos", de 1977.

${ }^{61}$ Relatório Anual de 1961.

${ }^{62}$ A nova Divisão de Extensão Cultural, dirigida nos primeiros anos por Hélio Emerson Belluomini, contava agora com Seção de Biblioteca e Divulgação, Seção de Museu, Seção de Desenho Técnico, Laboratório de Fotografia, Comissão de Publicações do IBu e Seção de Cursos.

${ }^{63}$ Relatório Anual de 1981 - carta de Rosa Pimont a Bruno Soerensen Cardozo, então Diretor Técnico do IBu, ao apresentar um quadro de "necessidades minimas urgentes" para a Divisão de Extensão Cultural.

${ }^{64}$ Esse período não foi contínuo. Rosa Pimont afastou-se do IBu em alguns anos, assumindo cargos em outras instituições.
} 
profissionalização) e ampliou as estratégias comunicativas utilizadas até então: antes de falecer, comandava um projeto de produção de materiais audiovisuais que posteriormente foi desenvolvido por Henrique Moisés Canter (atual diretor da Divisão de Desenvolvimento Cultural) e que culminou no Prêmio José Reis de Divulgação Científica, Menção Honrosa, categoria Instituição, em 1989.

Com um novo ciclo da atividade de ensino/aprendizagem inaugurado, percebe-se movimento similar de internalização de novas formas de pensar e agir em divulgação e educação que, certamente, ocorriam em meio a tensões e contradições (haja vista o fato da Divisão de Extensão Cultural permanecer 10 anos sem direção oficial). O processo criativo também fica evidente nas fontes analisadas, como, por exemplo, a elaboração de novas estratégias de ensino e o envolvimento de outros sujeitos que não zoólogos na elaboração e implantação de práticas educativas. Em 1982, Rosa Pimont apresentou seu plano bienal de trabalho ${ }^{65}$, intitulado "Estudo e Elaboração de Recursos Áudio-Visuais para o Institutto Butantan". O objetivo geral desse projeto era a "decodificação da informação especializada do Instituto Butantan, com fins de divulgação através de recursos audio-visuais”. Visava, como produto final, a elaboração de informativos, filmes, pôsteres e fôlderes, específicos para as diferentes "clientelas" (que deveriam ser identificadas pelo projeto).

Entretanto, esse segundo macrociclo observado na atividade de ensino/aprendizagem do Instituto Butantan teve duração mais curta que o primeiro. Apesar de alguns processos de externalização ainda continuarem ocorrendo na década de 1980, como será visto a seguir, já se observa uma nova fase nessa atividade, novamente pautada na ciência e seus conteúdos. A morte prematura de Rosa Pimont, a falta de uma equipe com formação específica e o descaso institucional podem explicar a duração mais curta deste segundo ciclo.

Inicia-se assim a terceira fase compreendida nesta investigação, que perdura até os dias atuais. Nesse terceiro ciclo, o conteúdo da atividade de ensino/aprendizagem volta a se pautar na ciência, mas não se constitui como um retorno ou como uma estagnação. Ele representa o movimento descrito por Vigotski (2007, p. 56) ao abordar o processo de internalização individual: "O desenvolvimento, neste caso [processo de memorização], como freqüentemente acontece, se dá não em círculo, mas em espiral, passando por um mesmo ponto a cada nova revolução, enquanto avança para um nível superior". Nessa nova fase, é possível detectar uma contradição proeminente: o foco volta à ciência, mas qual ciência? É

\footnotetext{
${ }^{65}$ Esse plano de trabalho tinha como responsável Rosa Pavone Pimont e como colaboradores Célia Regina Russo, Luiz Fernando Cunha, Regina Cecília Pressler e Henrique Moises Canter.
} 
fato que a produção científica do Instituto é extremamente ampla, mas os tópicos abordados nos processos de divulgação e educação são restritos. As necessidades emergentes estão relacionadas com a ampliação das temáticas abordadas, até mesmo para a criação de uma nova imagem institucional, não mais atrelada somente aos animais peçonhentos. Vê-se, nesse ciclo, por exemplo, a tentativa de resolução da contradição pesquisa ampla/ensino restrito, visando, entre outros, a construção da imagem de uma instituição voltada para a saúde pública, que pesquisa e produz com responsabilidade social e ambiental. Pequenas atividades, ciclos menores que podem ser utilizados como exemplo é a implantação do Museu Histórico e do Museu de Microbiologia, ampliando as temáticas abordadas, e o fortalecimento da Assessoria de Imprensa, que tem ajudado a construir uma nova imagem institucional.

Assim, a partir dessas reflexões e baseando-se nas ideias de Vigostski e de Engeström citadas anteriormente sobre o movimento em espiral, é possível representar graficamente os três ciclos expansivos da atividade de ensino/aprendizagem no Instituto Butantan como exposto na Figura 7.

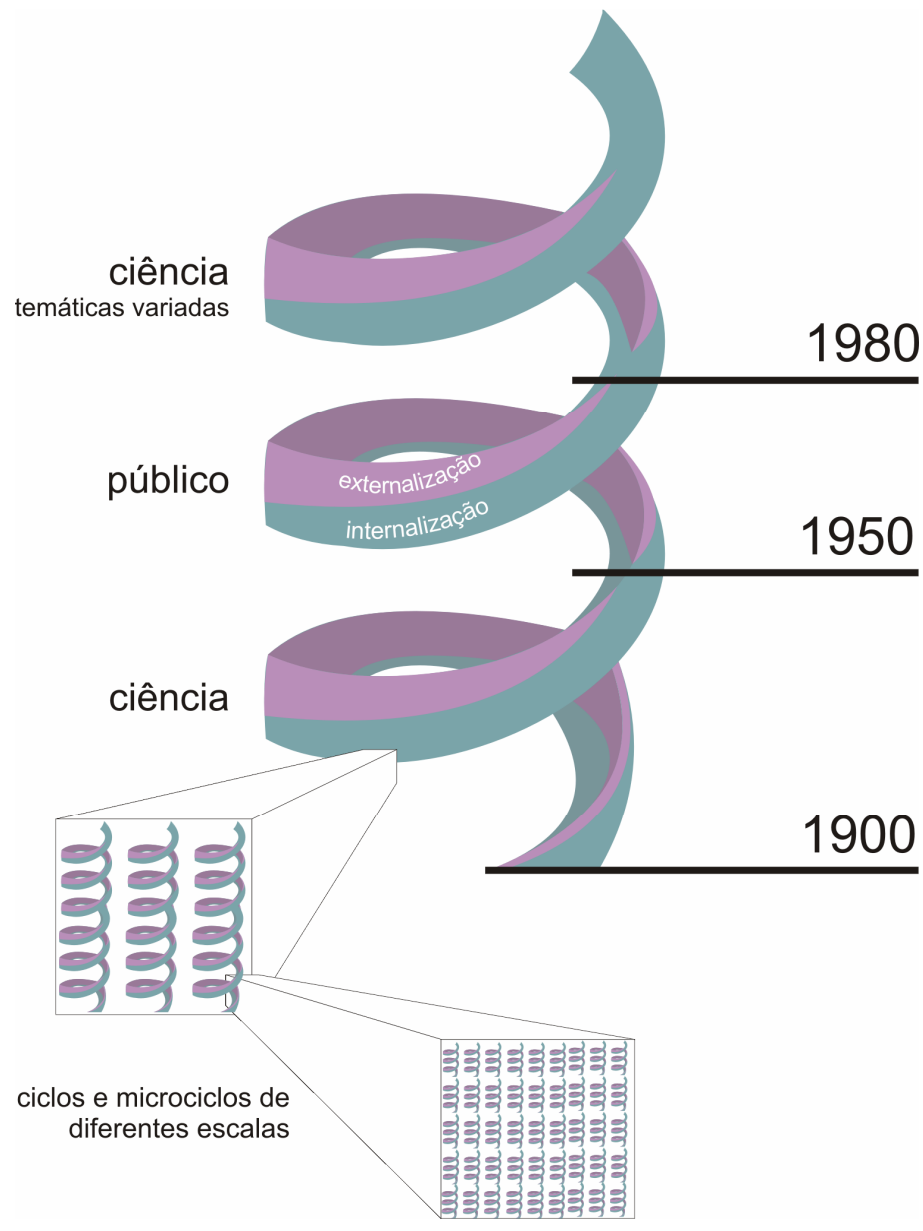

Figura 7 - Ciclos de aprendizagem expansiva observados ao longo do século XX na área educativa do Instituto Butantan, formado por microciclos de diferentes escalas (Arte gráfica: Antonio Carlos Ribeiro da Costa). 
Vale ressaltar que, do ponto de vista histórico, esses macrociclos não correspondem a cursos pré-determinados, com um direcionamento fixado externamente. O caminho assumido por ele depende das decisões tomadas localmente, dentro do próprio ciclo, em condições de incertezas e de permanente busca. Mas essas decisões não são arbitrárias, elas são respostas às contradições e tensões internas encontradas no sistema de atividade em uma determinada fase de sua evolução. Além disso, as contradições internas de uma fase específica podem ser mais ou menos identificáveis e, por conseguinte, mais ou menos disponíveis a serem resolvidas. Os modelos de resolução que não localizam ou eliminam as contradições podem resultar inexpressivos (ENGESTRÖM, 1999a). Nesse sentido, as resoluções particulares de cada contradição interna podem ser vistas como miniciclos de atividades de aprendizagem potencialmente, mas não necessariamente, expressivos:

Um ciclo expansivo em larga escala de transformação organizacional sempre consiste de pequenos ciclos de aprendizagem inovadora. Entretanto, o surgimento de ciclos de aprendizagem inovadora em pequena escala não garante, por si só, que um ciclo expansivo esteja acontecendo. Ciclos pequenos podem se dar como eventos isolados e o ciclo geral do desenvolvimento organizacional pode se tornar estagnado, regressivo, ou mesmo se desmoronar. A ocorrência de um ciclo expansivo independente não é comum e requer esforços concentrados e intervenções deliberadas (ENGESTRÖM, 1999b, p. 385 , tradução nossa).

Os macrociclos de atividade de aprendizagem expansiva podem ser vistos, portanto, como formados por ciclos de menor escala potencialmente transformadores. A constituição do Museu Biológico do Instituto Butantan pode exemplificar muito bem a ocorrência de microciclos expressivos e inexpressivos no interior de ciclos completos. Assim, serão trazidas a seguir, informações sobre as continuidades e descontinuidades na formação do acervo do museu, bem como nos seus modos de extroversão ao público, para um aprofundamento nesta questão.

\subsection{ESPECIFICAMENTE, O MUSEU}

Um dos elementos característicos de um museu é a sua coleção. Para se entender o desenvolvimento do Museu Biológico como tal, é preciso entender como se originou sua coleção e como foi mantida e extrovertida ao longo do tempo. 
A coleção de ofídios, atualmente denominada Coleção Herpetológica "Alphonse Richard Hoge", teve início nos últimos anos do século XIX. Como relata Vital Brazil ${ }^{66}$, esse material começou a ser colecionado desde seu ingresso no Instituto Bacteriológico, quando construiu um serpentário próximo à sua residência com animais trazidos de Botucatu, cidade onde morava anteriormente. Entretanto, foi nas primeiras décadas do século seguinte, com as viagens de coleta e, principalmente, com a intensa campanha de "propaganda popular" organizada por ele (que difundia o uso de permuta entre soros e cobras), que a coleção ofídica aumentou consideravelmente. Com essa campanha de divulgação, aliada à possibilidade ofertada à população de um local para depositar animais nem sempre desejados, o Instituto recebeu, até o ano de 1952, o gigantesco número de 604.688 exemplares de serpentes ${ }^{67}$. Embora alguns desses exemplares tenham sido coletados por funcionários do Instituto, permutados com instituições nacionais e estrangeiras ou comprados de colecionadores amadores $^{68}$, a grande maioria foi enviada por fornecedores da instituição. Da década de 1960 até hoje, 666.322 exemplares já foram recebidos ou coletados pelo Instituto ${ }^{69}$. Desse total (de quase 1,5 milhão de ofídios recebidos em um século), cerca de 80.000 foram tombados na coleção herpetológica. Somam-se ainda a esse montante, as coleções de crânios e de hemipênis, além da Coleção do Hospital Vital Brazil (animais que chegam com os acidentados) e a Coleção Didática.

Por vários anos, a coleção herpetológica ficou exposta ao público, ocupando locais variados, com diferentes investimentos e "curadorias". Inicialmente, os exemplares acondicionados no então chamando "museu" correspondiam a espécimes em vidros com álcool e peças biológicas alojados em uma sala, disponbilizados para a pesquisa e, de acordo com os registros encontrados (textos e imagens), expostos ao público em sua totalidade. Em 1914, esse acervo passou a ocupar o Prédio Principal, o primeiro edifício construído especificamente para o Butantan. Ao ser projetado, esse edifício já contava com uma sala destinada ao "Museu", no segundo pavimento, para abrigar a coleção de ofídios. Entretanto, nos Relatórios Anuais de 1917 ou, com mais detalhes, nos de 1919 e 1926, observa-se que o material exposto ao público não era composto somente de objetos da coleção de ofídios. As listas descritivas dos itens expostos, apresentadas nestes últimos Relatórios, mostravam a

\footnotetext{
${ }^{66}$ Brazil, V. Recordando... In: Memórias do Instituto Butantan, 14:IX-XII. 1940.

${ }^{67}$ Fonseca, F. Instituto Butantã - Sua origem, desenvolvimento e contribuição ao Progresso de São Paulo. In: São Paulo em quatro séculos, vol. 2. Instituto Histórico e Geográfico de São Paulo, editado pela Comissão do IV Centenário da Cidade de São Paulo. São Paulo, 1954.

${ }^{68}$ Relatório Anual de 1915.

${ }^{69}$ Dados fornecidos pela Seção de Cadastro do Laboratório de Herpetologia do Instituto Butantan.
} 
presença de partes anatômicas humanas ("coto de braço" ou "pé natural”), escorpiões fixados, quadros ilustrativos sobre dentição de serpentes e insetos vetores de doenças, além de "belíssimas péças modeladas em cêra, representando de modo perfeito, serpentes vivas e lesões anátomo-patológicas"70 (já havia um desenhista ceroplasta contratado desde de 1912 pela instituição ${ }^{71}$ ).

Nesse período, além de estar claro que a coleção de ofídios era utilizada tanto para pesquisa como exposição, pode-se ainda observar que, por vezes, era considerada o próprio "museu". Era comum, nos relatórios, o registro de "coleção" e "museu" como uma única referência. O seguinte trecho do Relatório Anual de 1915 ilustra bem essa situação:

Na publicação do Instituto distribuida ao inaugurar-se o novo edificio, na seção 'MUSEU' figuram 149 especies de ofídios, sendo 86 especies brasileiras ( Abril, 1914 ). Atualmente o numero de especies brazileiras existentes na coleção do Instituto eleva-se a 102 ( Janeiro de 1915 ).

O Museu (e a coleção de ofídios) por vários anos permaneceu em condições precárias $^{72}$. É provável que ao ser transferida do Prédio Principal para o Instituto dos Medicamentos Oficiais, em 1924, onde ocuparia o salão central, a exposição tenha ampliado a diversidade de objetos expostos: pela primeira vez foram exibidos espécimes vivos, além de sapos, peixes e lagartos ${ }^{73}$. Além disso, o "Museo foi enriquecido com uma pequena collecção de falsos remédios contra o ophidismo, taes como: chifre de veado calcinado, pedra belga, etc.”. Vale ressaltar que, nesse momento, a coleção de ofídios já não era apresentada em sua totalidade. Pela descrição da exposição feita por Vellard ${ }^{74}$, em 1925, e Vital Brazil, em 1926, somente alguns exemplares de serpentes fixadas e algumas peças biológicas estavam organizados para serem expostos. A grande maioria dos espécimes fixados ficou alojada na "Sala das Colleções".

Em 1926, o Museu passou a ocupar o prédio Lemos Monteiro (Figura 8). Na exposição então elaborada, ainda se percebe o uso de exemplares da coleção de ofídios,

\footnotetext{
${ }^{70}$ BRAZIL, V. Memória Histórica do Instituto Butantan. São Paulo: Elvino Pocai, 1941. 170p.

${ }^{71}$ Augusto Esteves, desenhista-ceroplasta, saiu do Butantan em 1919, juntamente com Vital Brazil, acompanhando-o na implementação do Instituto Vital Brazil, em Niterói (nesse período, foi contratado Rodolpho Ficher). Posteriormente, dedicou-se à produção ceroplástica voltada para a medicina. Parte de sua produção encontra-se atualmente no Museu Ceroplástico Augusto Esteves, na Faculdade de Medicina da Universidade de São Paulo. O acervo desse museu está há mais de seis anos acondicionado em um container, com possibilidades de, em breve, se incorporado ao acervo do Museu Histórico dessa faculdade (ANDRÉ MOTA, informação pessoal).

${ }^{72}$ Nesse texto, não serão detalhadas as diferentes fases por que passou o Museu do Instituto Butantan. Para uma análise mais aprofundada, ver Almeida (1995).

${ }^{73}$ Relatório Anual de 1925.

${ }^{74}$ Em 1925, Jean Vellard, médico francês especialista em aracnídeos, assumiu a chefia do Museu.
} 
embora de forma bastante reduzida. Posteriormente, na década de 1940, com nomeação de Wolgang Bürchel para a direção do Museu, este passou a ser mais organizado, com pequenas e constantes modificações. Para Bürchel, a exposição até então não apresentava uma sequiência lógica e mostrava um conteúdo "sem nexo, sem textos explicativos".

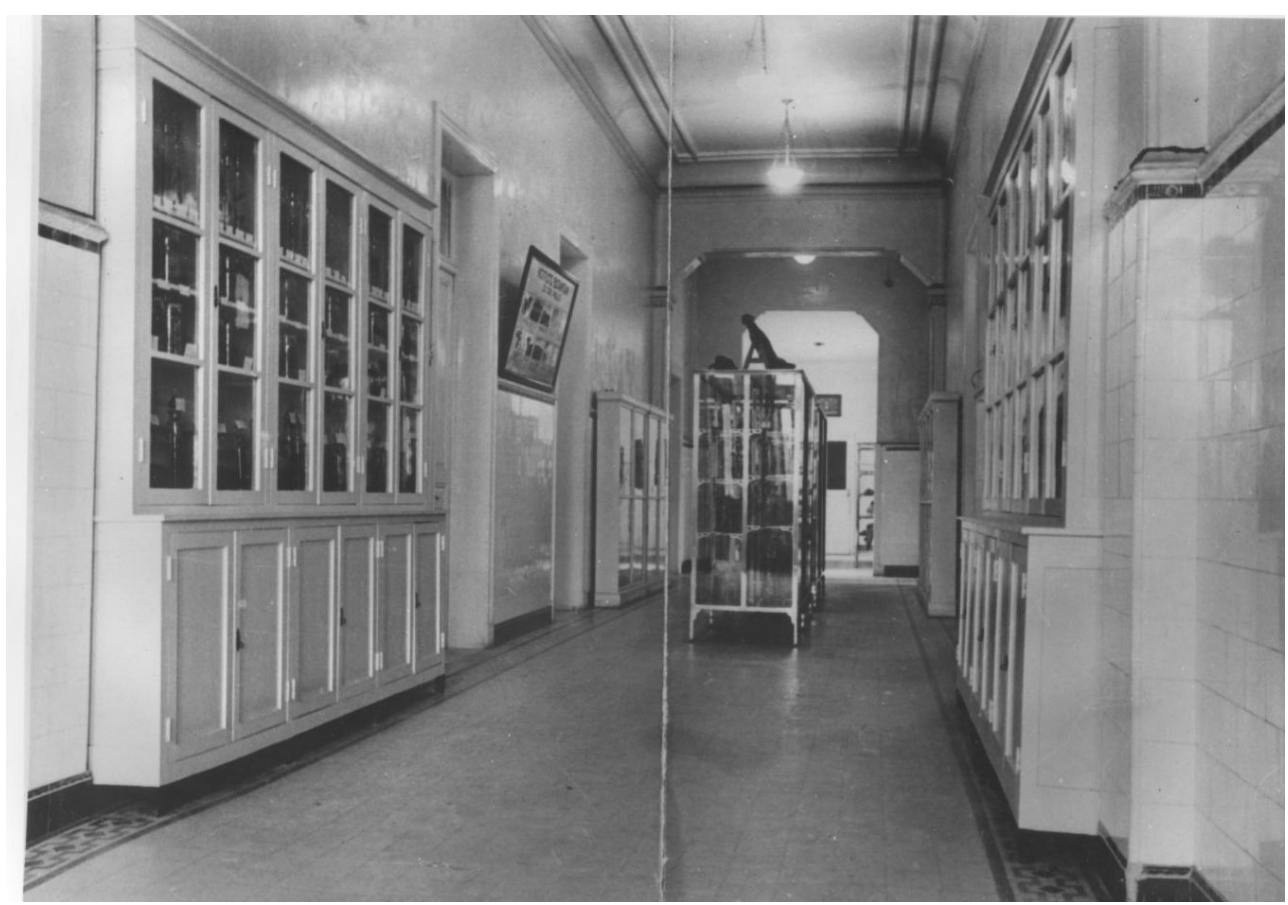

Figura 8 - Exposição do Museu no prédio Lemos Monteiro, em 1939 (Acervo Iconográfico do Instituto Butantan).

Assim, planejou o "Museu Provisório" que serviria de base para o "Museu Definitivo". Com a reformulação completa do que ele chamava de "mostruário", a nova exposição permanecia focada na "cellula-mater" do Butantan: serpentes, aranhas e escorpiões, tanto por falta de recursos como de espaço (ALMEIDA, 1995).

Essa exposição atendeu ao público até 1953, quando o Museu, a Sala de Conferências e parte do Serpentário "deixaram de funcionar" reaberto nas áreas de circulação do Prédio Novo e, de lá, foi transferido para a residência do Diretor (prédio que abriga hoje a Diretoria e Assessoria de Imprensa) (Figura 9). Nesse novo projeto, Bürchel apresentou uma das propostas mais detalhadas encontradas para o Museu,

\footnotetext{
${ }^{75}$ Relatório Anual de 1953.
} 
com plantas baixas, sugestões de expografia e orçamento ${ }^{76}$. Durante o início da década de 1960, a exposição, constantemente atualizada e acompanhada por exposições temporárias, permaneceu nesse local.

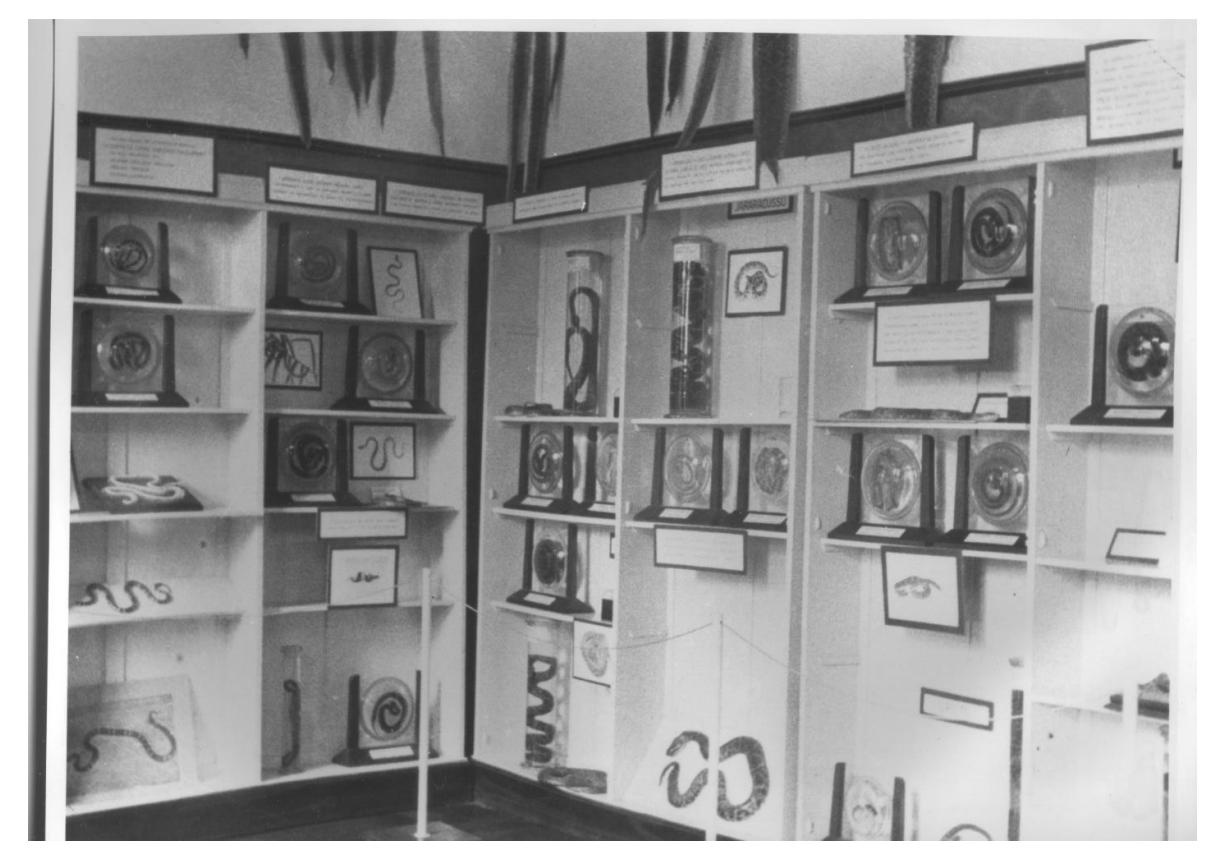

Figura 9. Exposição do Museu Provisório, em 1957 (Acervo Iconográfico do Instituto Butantan).

É possível perceber aqui diferentes pequenos ciclos de atividade de ensino/aprendizagem ocorrendo como constituintes do primeiro macrociclo de aprendizagem expansiva, iniciado com Vital Brazil. Por exemplo, em 1925, Vellard assumiu a incumbência de organizar o museu do Instituto em uma nova sala de visitação. Vê-se uma atividade de ensino, uma atividade de elaboração de uma prática educativa, no caso, a nova exposição do museu.

Nessa pequena atividade, Vellard tinha uma motivacão clara: ampliar o conceito de animais peçonhentos por meio da inclusão, na nova exposição, de espécimes de aranhas e escorpiões, até então, pouquíssimos representados. Ao atuar, ou seja, ao elaborar a nova exposição, Vellard reflete sobre os resultados de ações anteriores e de suas próprias ações e desenvolve novos modos de se organizar uma exposição. Essa é, portanto, uma atividade coletiva, pois mesmo sendo realizada por um indivíduo, conta com instrumentos mediadores construídos socialmente (p. e., os conceitos científicos abordados, a legenda ou mesmo a

\footnotetext{
${ }^{76}$ Relatório Anual de 1957.
} 
própria linguagem) e com ações desenvolvidas por outros sujeitos (como a produção de peças ceroplásticas por Augusto Esteves).

Esse microciclo de aprendizagem, em que os sujeitos internalizaram conceitos e modos de se fazer uma exposição e externalizaram novas formas, fazem parte de um ciclo maior, o ciclo baseado no conceito de "plano de vulgarização" de Vital Brazil. Ele pode ser localizado em um ponto inicial desse macrociclo, em que o processo de internalização é mais intenso do que o de externalização. Esse posicionamento pode ser mais facilmente evidenciado ao se considerar um outro exemplo de microciclo que poderia ser incluído em um ponto posterior da espiral, em um momento em que a externalização torna-se o processo principal.

Como visto anteriormente, são as tensões e contradições internas de um ciclo a sua força motriz, o que o leva adiante. Nesse primeiro ciclo, uma tensão observada em diversos momentos e que se avoluma gradativamente é a organização interna do museu e sua consequente manifestação na exposição. Retomando o que Bürcherl, um dos diretores do Museu, apresentou em um Relatório Anual da década de 40, a exposição não continha uma "seqüência lógica" e mostrava um conteúdo "sem nexo, sem textos explicativos". Somada aos seus projetos de estruturação do museu (passando por uma fase provisória anterior a uma definitiva) e às outras falas registradas nos relatórios, essa insatisfação de Bürcherl pode representar a tensão entre a ênfase na ciência e a ênfase no público encontrada nos processos de divulgação e educação em ciências quando foi analisada a atividade de ensino/aprendizagem do Instituto Butantan, apresentada anteriormente. Ao propor uma reorganização da apresentação de objetos museais e conceitos científicos para um melhor entendimento pelo público, inicia-se um questionamento à crença de que, por si só, esses elementos garantem a compreensão do que se quer comunicar.

A necessidade de organização da ação educativa, nesse momento, motivava ainda outras pequenas atividades. Em 1966, com o término da reforma da antiga cocheira, o Museu passou a ocupar o espaço em que permanece até hoje (Figura 10). Pelos relatórios seguintes, é possível perceber que a exposição manteve a mesma estrutura da anterior, mas alguns novos elementos foram acrescentados, como o grande número de terrários com serpentes vivas, vitrinas de seis metros de comprimento e um aparato interativo do tipo push-bottom (guizo de cascavel sonante). 


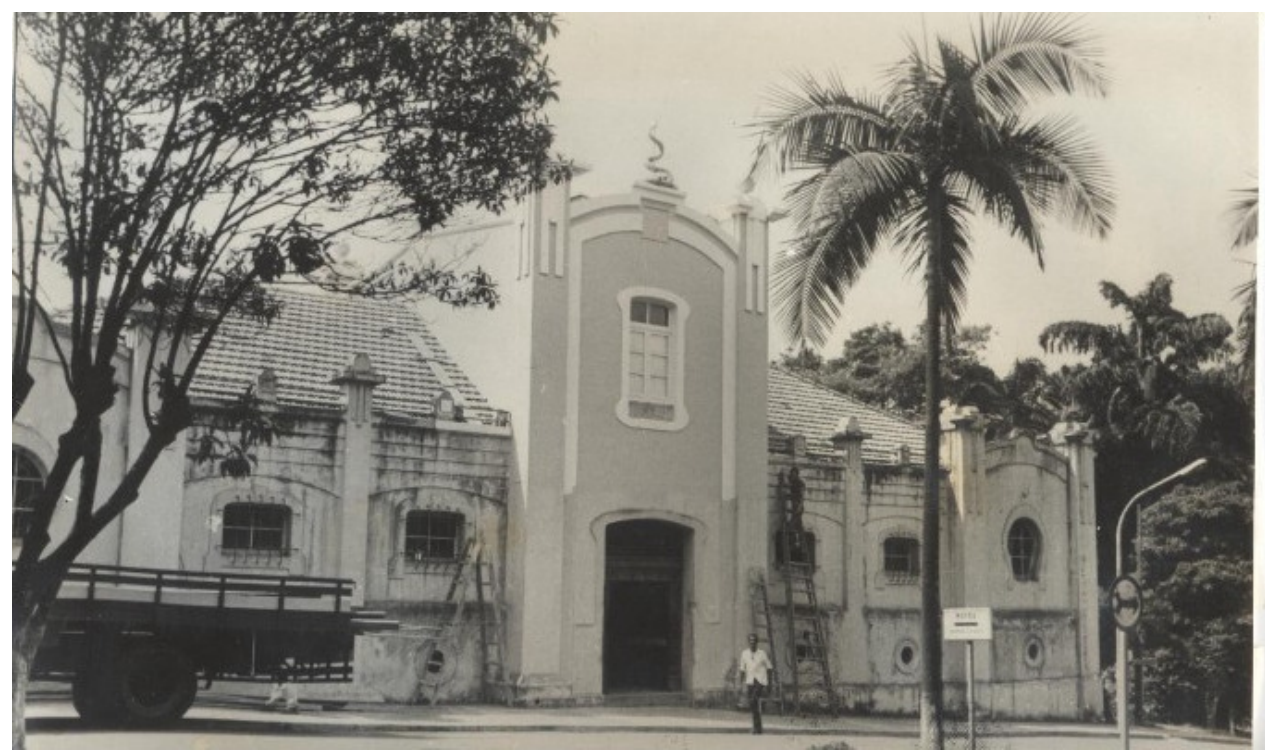

Figura 10. Reforma da antiga cocheira que passou a abrigar o Museu do Instituto Butantan desde 1966, em 1972 (Acervo Iconográfico do Instituto Butantan).

Entretanto, como ressalta Almeida (1995), o stand destinado à "varíola, raiva, plano de vacinação da secretaria de Saúde", temas propostos pela direção do Museu, não foi implantado por falta de verbas. O tema "varíola" só foi incorporado à exposição em 1975, quando o Museu já estava sob a chefia de Henrique Moises Canter ${ }^{77}$.

Essa falta, a de outros temas que não animais peçonhentos e afins, é recorrente na história do Instituto e do Museu: as tentativas de implementar exposições e/ou museus de temática mais ampla, como um Museu da Higiene, aparecem constantemente em seus relatórios anuais. Observa-se essa perspectiva já em 1921, quando o então diretor Rudolph Kraus ressaltou que

não menos importante tambem é a divulgação scientifica sobre as enfermidades infecciosas para o publico (...). É meu desejo tambem modificar o actual museu do Instituto, que é mais um museu de cobras, e formar um outro em que se exponham assumptos sobre hygiene em geral, não sendo impossivel pensar-se no futuro em construir-se um pavilhão ao lado do Instituto e que sería destinado á installação de um completo Museu de Hygiene ${ }^{78}$.

\footnotetext{
${ }^{77}$ O Prof. Canter, como é conhecido na instituição, foi chefe do Museu de 1971 a 1983, quando assumiu a direção da Divisão de Desenvolvimento Cultural.

${ }^{78}$ Relatório Anual do Instituto Butantan de 1921.
} 
Essa perspectiva, de apresentar o Instituto como um órgão ligado à saúde pública e não somente ao combate aos animais peçonhentos, continuou em vários outros projetos que não foram concretizados. Mesmo na possibilidade de um novo museu, com a reforma da antiga cocheira na década de 60, foi implementada uma exposição voltada para animais peçonhentos. No Relatório Anual de 1968, dois anos após a inauguração da nova exposição, Jandira Planet do Amaral, então diretora da instituição, reforçou a necessidade do instituto contar com um museu mais dinâmico em relação à saúde pública.

Todas essas iniciativas de mudança de temática, em que sujeitos puseram-se em atividade mental de elaboração de novas estruturas museais, podem ser consideradas como microciclos de atividade inexpressivos. São pequenas atividades que permaneceram como eventos isolados, sem continuidade. Caso tivessem resultado como expressivas, poderiam constituir outros ciclos de macroatividade que não os observados.

Em 1984, Pedro Federsoni assume a direção do Museu e, junto com sua equipe, deu, gradativamente, um caráter de educação ambiental à exposição de longa duração, culminando na proposta que marcou a década de 1980: o tema "Na natureza não existem vilões". Nessa exposição, o aumento no uso de recursos expográficos foi significativo: dioramas, biodioramas, vitrinas, objetos variados (réplicas, modelos em massa, animais taxidermizados, animais vivos), aparatos interativos, legendas com textos diferenciados (públicos adulto e infantil), terminal computadorizado com software sobre animais venenosos e área para exposições temporárias foram disponibilizados ao público.

Esse período foi bastante importante para o Museu enquanto instituição educativa. Com a temática escolhida para a exposição de longa duração, observa-se uma série de práticas voltadas para a Educação Ambiental (como elaboração de dinâmicas e produção de material educativo) e o retorno da valorização da pesquisa científica na área para o enriquecimento dessas práticas, preterida após o falecimento de Rosa Pimont ${ }^{79}$.

É possível considerar que as atividades de ensino/aprendizagem ocorridas nesse processo pertencem ao segundo macrociclo de atividade da Instituição, em que o público passa a ser referencial para as ações desenvolvidas. Estas atividades podem ainda ser relacionadas a (mas não determinadas por) um movimento externo à instituição, que acontecia em âmbito internacional de estruturação de setores educativos nos museus (HEIN, 1998).

\footnotetext{
${ }^{79}$ A produção científica na área de Educação volta a ocorrer, com a publicação de artigos científicos e a participação em eventos científicos.
} 
Na última reforma realizada na exposição de longa duração do Museu Biológico, financiada por uma empresa privada ${ }^{80}$ e pela Fundação Butantan, foram feitas mudanças significativas, desde sua reestruturação interna, incluindo os biotérios e os mecanismos de manutenção dos animais, até a expografia. Nesse período, assumiu a chefia do Museu Biológico $^{81}$ o pesquisador transferido do Laboratório de Herpetologia, Giuseppe Puorto. O uso de recursos expográficos foi reduzido em relação à exposição anterior, mas atenção maior foi dada à manutenção dos animais. Na atual exposição de longa duração, são observados aproximadamente 80 aparatos, sendo eles, em sua maioria, dioramas com espécimes vivos (biodioramas). Há ainda dioramas com réplicas ou animais taxidermizados, aquários de água doce e água salgada, vitrinas temáticas (Reprodução e Osteologia) e pôsteres imantados e totens interativos, com softwares. ${ }^{82}$

Embora ainda se mantenha uma exposição construída como "mostruários de animais venenosos" e local de divulgação de medidas preventivas de acidentes com esses animais, nesse novo ciclo da espiral, há uma preocupação em contextualizar esses saberes científicos, em relacioná-los com outros conhecimentos, como os produzidos pelas pesquisas em evolução e conservação ${ }^{83}$, o que pode ser considerado, indiretamente, um olhar para o público.

Vê-se assim que o atual discurso expositivo do Museu Biológico, bem como o discurso do Instituto Butantan, não surge do acaso, nem mesmo é fruto somente da idealização de alguns sujeitos contemporâneos. Ele é o resultado atual de uma série de resoluções de contradições e conflitos, com suas continuidades e descontinuidades, presentes em atividades transformadas ao longo do tempo por diferentes sujeitos.

É importante esclarecer que, ao se pontuar determinados atores, citando especificamente seus nomes, não se pretendeu criar novos mitos ou tecer homenagens. Buscou-se, sim, encontrar, como sugere Engeström (1999b), sujeitos referenciais, pelos olhos dos quais pudesse ser realizada uma análise do interior da atividade. As análises a partir do interior, somadas àquelas vistas externamente, em um sobrevôo, permitiram uma melhor

\footnotetext{
${ }^{80}$ DuPont do Brasil.

${ }^{81}$ Segundo Henrique Moisés Canter, o Museu passou a se chamar Museu Biológico no decreto de organização $\mathrm{N}^{\circ} 33.116$ de 13/03/91. No decreto anterior, possivelmente de 1966, como era o único, denominava-se apenas Museu (CANTER, H. Publicação eletrônica [mensagem pessoal]. Mensagem recebida por alessandra@butantan.gov.br em 02 abr. 2008).

${ }^{82}$ Atualmente, encontram-se impossibilitados de serem utilizados pelo público.

${ }^{83}$ Exemplos são as exposições temporárias "Jararacas das Ilhas de São Paulo" (2006) e "Procura-se! Anfíbios ameaçados de extinção" (2008) e as oficinas educativas desenvolvidas no Núcleo de Educação Terra Firme do Museu Biológico voltadas para conservação.
} 
utilização do referencial histórico-cultural da Teoria da Atividade, principalmente do pressuposto de que a cognição e o comportamento humanos estão fortemente atrelados em sistemas de atividade mediados por artefatos, coletivamente organizados.

Além desse movimento espacial de análise, o outro movimento escolhido, o temporal, favoreceu o melhor entendimento do fenômeno estudo. Ao se olhar para o sistema de atividade como constituído por ciclos de atividade expansiva de diferentes escalas de tempo, foi possível dar uma outra dimensão para a atividade de ensino/aprendizagem do Instituto Butantan. Ao compreender os ciclos como constituídos por processos de internalização e externalização, tornou-se possível atribuir às instituições de pesquisa como o Butantan, um caráter de ensino, mas também de aprendizagem: elas continuamente se apropriam de novas formas de interação com seu público, formas essas que podem promover o desenvolvimento dos sujeitos envolvidos, sejam eles internos ou externos à instituição.

A perspectiva temporal de análise traz ainda uma possibilidade frutífera: a de olhar dinamicamente para fenômenos de maior magnitude (macrociclos) concomitantes aos de menor escala (microciclos), sintetizados na unidade de análise - a atividade de ensino/aprendizagem. É possível olhar, ao mesmo tempo, para a instituição e o indivíduo, para o ano e o minuto, para o geral e o local, e entender como esses elementos se relacionam intrinsecamente. E é esse exercício de análise que será continuado no capítulo a seguir, agora no tempo do indivíduo (mesmo o indivíduo social), do minuto, do singular. 
Capítulo 4

Ciclos e microciclos de Atividade de Ensino/Aprendizagem em museus de ciências 



\section{CICLOS E MICROCICLOS DE ATIVIDADE DE ENSINO/APRENDIZAGEM EM MUSEUS DE CIÊNCIAS}

No capítulo anterior, foi apresentada uma possível "reorquestracão" de diferentes vozes, de diferentes pontos de vista que ajudaram a compor a atividade de ensino/aprendizagem do Instituto Butantan (e especificamente de seu Museu Biológico), ao longo do século XX. Com isso, foi possível identificar os ciclos passados desse sistema de atividade, o que é de grande importância para o entendimento dos atuais microciclos de aprendizagem expansiva. Para se identificar as tensões e as contradições contemporâneas e as possíveis soluções encontradas (passos fundamentais para a apreensão do movimento da atividade), é necessário o entendimento de como esses elementos apresentaram-se em outros momentos, já que a formação de uma nova estrutura social deve estar baseada em alguma anteriormente existente.

Vale então questionar: em que ponto da espiral encontram-se os microciclos atuais? Como a unidade de análise escolhida, a atividade de ensino/aprendizagem, pode contribuir para a compreensão do todo e não somente de momentos temporalmente distintos, de forma isolada? Para responder a isso, é preciso uma análise reflexiva das estruturas atuais desse sistema de atividade, baseada nas estruturas passadas, bem como a investigação de como se dão a apropriação de modelos e ferramentas para resolver os atuais conflitos internos e a busca por novas soluções para esses conflitos.

Essa opção por investigar as tensões e as contradições de um fenômeno corresponde à escolha pelo método histórico dialético de investigação, que busca perceber a unidade, o movimento que evidencia os contraditórios, que os incluem um no outro e ao mesmo tempo os quebra ou os supera (LEFEBVRE, 1987). Além disso, a escolha desse método de investigação pressupõe a análise do todo pela unidade, o olhar em diferentes escalas espaciais e temporais. Como coloca Cedro (2008, p. 96) ${ }^{84}$,

a característica principal do método histórico dialético é a de que o fenômeno estudado deve ser apresentado de tal modo que permita a sua apreensão em sua totalidade. Logo, uma série de aproximações contínuas cada vez mais abrangentes é necessária para que este se torne acessível ao indivíduo.

Ao compreender o componente dialético do método como representado pelo conflito de contrários, o autor traz as concepções de Bottomore $(2001)^{85}$ de que a realidade concreta não

\footnotetext{
${ }^{84}$ Esse autor, em sua tese de doutoramento, traz uma contextualização histórica dos conceitos de dialética e materialismo e tece uma apresentação bastante clara das principais características do método histórico dialético.

${ }^{85}$ BOTTOMORE, T. Dicionário do pensamento marxista. Rio de Janeiro: Jorge Zahar, 2001.
} 
é estática, mas essencialmente contraditória e é esse estado que a faz avançar em um processo histórico de transformações descontínuas. Como ressalta o autor,

dessa forma, podemos entender que, na perspectiva mais básica da lógica, a natureza contraditória da realidade leva ao surgimento de afirmações conflitantes. Estas, por sua vez, constituem-se em verdades, pois estão vinculadas à própria realidade, logo, elas exigem uma forma de pensamento que supere a lógica formal. Portanto, há necessidade do surgimento de uma lógica dialética que entenda o princípio da contradição. A lógica dialética, ao partir do princípio da contradição, considera que tudo está em movimento, e que qualquer tipo de movimento é gerado pela coexistência de diversos elementos contraditórios na totalidade de determinado sistema (CEDRO, 2008, p. 95).

O componente materialista aqui é entendido, portanto, não como uma redução das ideias à matéria, mas estes, ideia e matéria, são vistos como opostos que constituem uma unidade, na qual o material é considerado forma básica. Essa base material é constituída de forças produtivas e relações de produção que em si carregam suas contradições. Na perspectiva dialética, essas contradições não devem ser tomadas como coisas mortas, definidas e estáveis, mas como coisas vivas, móveis, em constante transformação (LEFEBVRE, 1987).

O componente histórico, por sua vez, relaciona-se ao materialismo e inclui o desenvolvimento e o movimento inerentes à realidade como atrelados às transições de seus aspectos e suas contradições. Como coloca Oliveira (2005),

as transformações qualitativas, tanto na história do sujeito como na história cultural, ocorrem por meio da chamada síntese dialética. Esta se refere à emergência de algo novo, anteriormente inexistente. Esse componente novo não está presente nos elementos iniciais de uma dada situação, mas é tornado possível pela interação entre esses elementos, num processo de transformação que gera novos fenômenos.

Assim, as contradições são situadas historicamente, mas seu conteúdo é continuamente reformulado. A dinâmica tese/antítese/síntese expressa essa transformação, ao considerar que, na oposição, tese e antítese geram a realidade concreta, que uma vez sendo síntese, torna-se novamente tese, que por sua vez já carrega a antítese, que em um novo conflito trará nova síntese, num contínuo devir.

Nesse sentido, o método histórico dialético de pesquisa, ao procurar a unidade, o movimento que engendra os contraditórios, busca também suas sínteses e os novos fenômenos que daí surgem.

Para apreender esse movimento, agora em uma escala de microciclos de atividade de aprendizagem expansiva, esta investigação procurou observar as tensões e contradições atualmente presentes na atividade de ensino/aprendizagem em um museu de ciências, bem 
como as soluções encontradas pelos sujeitos ativos envolvidos. Assim, foram escolhidos dois sujeitos, pelos olhos de quem a análise foi conduzida: os grupos de visitantes e a equipe de profissionais do Museu Biológico do Instituto Butantan.

Por estas duas óticas, procurou-se compreender como estaria estruturado um microciclo de atividade de ensino/aprendizagem em um museu de ciências, entendendo-o como uma atividade coletiva.

\subsection{A COLETA DE DADOS - VISITANTES E PROFISSINAIS DE MUSEU}

Para responder a essas questões, considerando-se a ótica do grupo de visitantes, foi necessário optar por sujeitos específicos face à grande variedade de possibilidades interativas estabelecidas pelos diferentes públicos do Museu Biológico. Assim, foram escolhidos grupos não escolares, bastante representativos da audiência desse museu, como sujeitos da pesquisa. Esses visitantes não recebem atendimento específico pelos educadores da instituição (o agendamento de grupos para realização de atividades educativas planejadas restringe-se aos escolares), tendo como uma das poucas possibilidades de mediação sujeito/sujeito externas ao grupo a presença de monitores no salão da exposição de longa duração.

Entre o público não escolar, optou-se pelos agrupamentos mistos, que incluíssem até quatro adultos e crianças de até 12 anos, considerados como "família". As ideias de Minuchin (1990), de que a família é um grupo social primário, que influencia e é influenciado por outras instituições, constituído por membros organizados por diferentes critérios (como interesse, geração, sexo) e com diferentes níveis de poder e funções, fornecem elementos para a compreensão de como se constituem e se organizam os grupos familiares. Na família, os comportamentos de um membro influenciam os demais e as diferenças nos parâmetros culturais não encerram os valores universais. Como colocam Ellenbogen, Luke e Dierking (2004), os membros de uma família, vistos como uma comunidade de prática, compartilham valores, vocabulários, interesses e compreensões e, sendo assim, as ações de um membro são interpretadas pelos demais, permitindo a construção de significados específicos ao grupo a que pertencem.

Dessa forma, a estrutura nuclear da família geralmente reconhecida como tal, composta de um homem, uma mulher e filhos, pode e deve ser ampliada, abrangendo outros papéis cada vez mais presentes em nossa sociedade. Dessa forma, nesta pesquisa, foram considerados como família os grupos que apresentaram relações de parentesco, embora não 
necessariamente de consangüinidade. O fato de um agrupamento de crianças e adultos apresentar uma interação regular e recorrente, com continuidade, foi o critério principal para ser considerado como grupo familiar. O número limitante de quatro membros por grupo foi imposto por questões tecnológicas. Os equipamentos utilizados para a coleta de dados permitiam a gravação de vozes de somente quatro pessoas por visita.

As famílias que atenderam aos critérios de grupo misto e de até quatro pessoas foram abordadas na entrada do Museu Biológico e, após explicações sobre o projeto de pesquisa, convidadas a participarem de duas entrevistas (anterior e posterior à visita) e da gravação em áudio e vídeo de sua visita. No total, após numerosos testes frustrados de adaptação da tecnologia escolhida para essa pesquisa, foram entrevistadas e gravadas 15 famílias.

A primeira entrevista consistia em questões sobre dados pessoais (nome, idade, parentesco, escolaridade, endereço, e-mail, telefone e profissão), sobre as relações estabelecidas pela família com as instituições museais, de forma quantitativa (número de visitas a museus no último ano, museus visitados, número de visitas ao Museu Biológico) e qualitativa (motivos para visitar museus, motivos para visitar o Museu Biológico, percepções sobre museus e sobre o Museu Biológico), além de suas expectativas em relação à visita. Para isso, foram utilizadas questões fechadas e abertas, imagens de diferentes espaços museais para que os visitantes selecionassem as que consideravam mais relacionadas à instituição museu, frases sobre aprendizagem para serem selecionadas caso estivessem relacionadas a museus na visão dos entrevistados e uma lista de possíveis ações desenvolvidas em uma atividade de visita também a serem selecionadas por eles (Apêndice 2). Esses dados foram importantes para a compreensão do grau de aproximação às instituições museais que as famílias possuem e os motivos que as levam a realizar uma atividade de visita ao Museu Biológico.

Mas, como o referencial teórico escolhido sugeria que as interações estabelecidas entre os membros do grupo e entre eles e a exposição seriam de fundamental importância para compreender a atividade de visita como uma atividade de aprendizagem, em movimento constante, em processo e não em produto, entrevistas pré e pós-visita não seriam suficientes para dimensionar essas relações. Assim, procurou-se registrar as ações desenvolvidas durante a visita, em áudio e vídeo.

Foram então colocados microfones de lapela sem fio em cada um dos sujeitos ${ }^{86}$. Esses microfones foram escolhidos por possibilitarem a livre circulação dos visitantes ao longo das

\footnotetext{
${ }^{86}$ Modelo Le Son LS 202, pertencente ao Laboratório de Pesquisa em Ensino de Química e Telemática Educacional (LAPEQ/USP).
} 
exposições. O microfone foi colocado na vestimenta de cada membro do grupo, o mais próximo possível de sua face. O microfone era conectado por um fio ao emissor, preso na roupa do visitante, geralmente na altura da cintura. Esse emissor sem fio enviava sinais para dois receptores sintonizados na mesma freqüência (uma freqüência para cada membro do grupo), localizados nas "esquinas" do salão em formato de "U" e ligados a uma mesa de som $^{87}$ cada (Apêndice 3). Nessa mesa, os quatros canais eram mixados, compondo um único registro armazenado em um gravador digital ${ }^{88}$. Dessa forma, era possível registrar a seqüência das interações conversacionais estabelecidas pela família.

Além desses microfones, cada visitante recebeu um gravador digital ${ }^{89}$, preso em sua calça, com um microfone de lapela ${ }^{90}$. O inconveniente desse procedimento é que cada visitante portava dois microfones. Mas, por outro lado, com o uso de dois microfones, foi possível garantir a gravação da voz de cada membro do grupo em canais de áudio separados.

Para a transcrição da gravação de áudio foi utilizado o software Audacity 1.3.5, que viabilizava a audição de cada arquivo separadamente ou em conjunto. Esse software foi de fundamental importância, pois permitia ainda minimizar o ruído de fundo do Museu Biológico, que era extremamente alto.

A visita de cada família foi registrada também em vídeo, com uma Handcam de HD interno $^{91}$, possibilitando a gravação contínua da visita. O responsável pela filmagem permanecia a uma distância razoável do grupo familiar, minimizando a provável interferência provocada pelo registro. Para sincronização de áudio e vídeo foi utilizado o programa Pinnacle Studio9.

Após a visita, o grupo era abordado para retirada dos equipamentos e então questionado sobre suas expectativas (Foram alcançadas? Por quê? Voltaria ao Museu? O que diria a outras pessoas?) e sobre suas ações (Quais ações se lembra de ter realizado durante a sua visita?).

Pensando ainda nos outros elementos constituintes de um sistema de atividade, procurouse compreender as motivações e ideias da equipe administrativa/educativa do Museu Biológico em relação à atividade de visita às suas exposições, sob um ponto de vista histórico e cultural. A dimensão histórica sugeriu uma análise mais cuidadosa dos processos que

\footnotetext{
${ }^{87}$ Modelo Wattsom MSx 6 canais, pertencente ao Laboratório de Pesquisa em Ensino de Química e Telemática Educacional (LAPEQ/USP). Houve a necessidade da utilização de dois receptores ao longo das exposições devido às dificuldades impostas por obstáculos arquitetônicos.

${ }^{88}$ Modelo Sony ICD-P530F.

${ }^{89}$ Modelo Panasonic QR170.

${ }^{90}$ Modelo Clone Microfone de Lapela Multimídia.

${ }^{91}$ Modelo Sony Handycam DCR-SR300 40 Gb.
} 
levaram ao atual discurso expositivo e da compreensão dos profissionais do museu como sujeitos participantes de comunidades de práticas relacionadas à visitação pública. A dimensão cultural sugeriu uma análise relacional, integrada, dos discursos dos diferentes atores envolvidos na elaboração e no desenvolvimento da atividade de visita.

Para compreender a estruturação dos atuais discursos expositivos, nessa perspectiva, foram utilizados os resultados da análise documental, citados no capítulo anterior. Além disso, foram consideradas as falas de diferentes profissionais (monitores ${ }^{92}$ e bioteristas). Para isso, foram desenvolvidas entrevistas semi-estruturadas com questões iniciais voltadas para o levantamento da formação do profissional, suas ideias sobre a relação de seu trabalho com a atividade de visita e suas motivações e expectativas em relação a essa atividade. As entrevistas foram registradas em gravadores digitais, acompanhadas de anotações de campo. Foram obtidas quatro entrevistas com monitores e duas com bioteristas do Museu.

De todas as entrevistas registradas (15 grupos de visitantes, quatro monitores e dois bioteristas), somente algumas foram utilizadas para análise. Os sujeitos envolvidos selecionados (três famílias e dois monitores) serão apresentados, em itens específicos, após uma descrição da exposição analisada.

\subsubsection{A exposição de longa duração do Museu Biológico}

A exposição escolhida para análise de microciclos de ensino/aprendizagem é apresentado pelo Museu Biológico do Instituto Butantan.

Como visto, essa exposição é um dos resultados de mais de 100 anos de ações de divulgação científica e educação em ciências desenvolvidas pela Instituição. Ao longo do século XX, foram elaboradas exposições para atendimento do público visitante, sempre com o intuito de informar à população as características dos animais peçonhentos pesquisados no Instituto. Na última reestruturação da exposição de longa duração, foram realizadas mudanças significativas não somente no espaço expositivo, mas também na área restrita aos funcionários, incluindo os biotérios e os espaços necessários para a manutenção dos animais. Em 2001, no aniversário de centenário da Instituição, a nova exposição foi aberta ao público, acompanhada de um auditório para projeção de filmes (atualmente utilizado nas intervenções dos monitores junto a grupos escolares).

92 São numerosas as denominações atribuídas aos profissionais de museu que atendem diretamente o público, entre outras funções: monitor, mediador, educador, guia, etc. Nesta investigação será utilizado o termo monitor, mantendo o uso observado no museu estudado. 
No período em que a coleta de dados dessa pesquisa foi realizada (novembro de 2006 a fevereiro de 2007), havia ainda uma exposição temporária sobre serpentes de ilhas do Estado de São Paulo, produzida por membros do Museu Biológico em parceria com o Centro de Toxinologia Aplicada (CAT - CEPID/FAPESP) e o Museu de Zoologia da Universidade de São Paulo. Essa exposição temporária também foi analisada.

A exposição de longa duração contava com 77 aparatos (61 biodioramas ${ }^{93}, 03$ dioramas com animais vivos e taxidermizados, 01 diorama com réplica, 03 aquários, 01 vitrina sobre Reprodução, 01 vitrina sobre Osteologia e 07 pôsteres). Já a exposição temporária contava com 08 aparatos (01 vitrina com maquete, 02 dioramas com réplicas de serpentes e 05 pôsteres). Todos os dioramas da exposição de longa duração buscavam uma aproximação do ambiente original dos animais, por meio de pinturas e uso de plantas naturais e artificiais, folhas secas, galhos, rochas, fontes de água e substratos diversos (areia, argila etc.) (Figura 11). Diferentemente, os dioramas da exposição temporária apresentavam uma ambientação que apenas sugeria o ambiente original das serpentes por meio de uma pintura mais estilizada, menos precisa (Figura 12). Maior atenção foi dada às réplicas, que além de representarem o animal em si, apresentavam ainda uma interação com outros animais (relações de predação). Além disso, foram utilizados outros recursos expositivos como maquetes, mapas e imagens fotográficas.

Nas Tabelas 5 e 6, são apresentados os aparatos constituintes da exposição de longa duração e da exposição temporária, evidenciando a predominância de biodioramas em relação a outros recursos expositivos, como pôsteres, maquetes ou dioramas com outros objetos.

\footnotetext{
${ }^{93}$ Os dioramas com animais vivos foram considerados como "biodioramas" (cf. MARANDINO, 2001).
} 


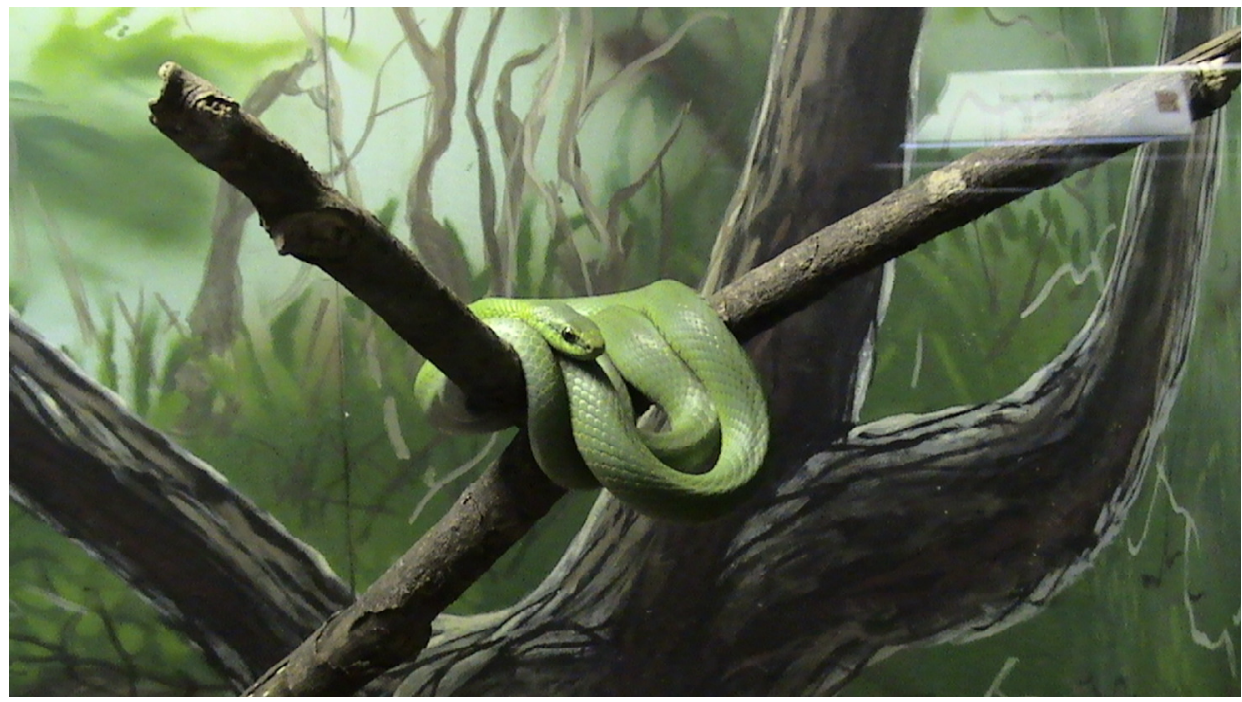

Figura 11 - Biodiorama de boiubu, na exposição de longa duração do Museu Biológico do Instituto Butantan (Foto: Alessandra Schunck).

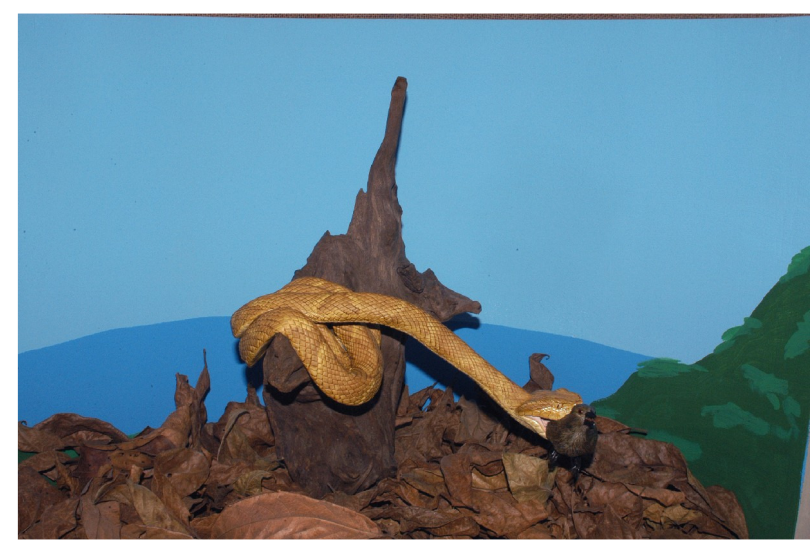

a.

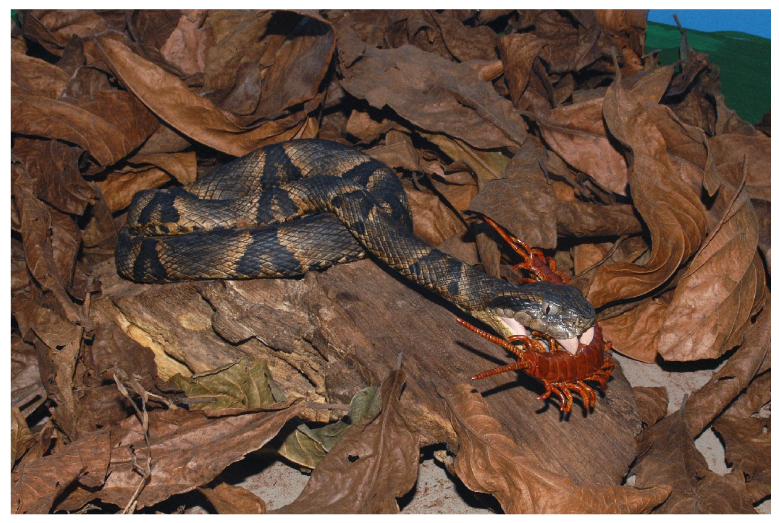

b.

Figura 12 - Dioramas de jararaca-ilhoa (a) e de jararaca-de-alcatraz (b), na exposição temporária Serpentes das Ilhas de São Paulo (Fotos: Antonio Carlos O. R. da Costa). 
Tabela 5. Aparatos da exposição de longa duração do Museu Biológico do Instituto Butantan.

\begin{tabular}{|c|c|}
\hline Aparato & Descrição \\
\hline 1 & Biodiorama de jibóia (Boa constrictor constrictor) \\
\hline 2 & Biodiorama de píton albina (Piton molurus bivittatus) \\
\hline 3 & Pôster sobre identificação de serpentes peçonhentas e não peçonhentas \\
\hline 4 & Biodiorama de iguana (Iguana iguana) \\
\hline 5 & Biodiorama de sucuri (Eunectes murinus) \\
\hline 6 & Pôster sobre a distribuição do soro por regiões \\
\hline 7 & Biodiorama de cascavel (Crotalus durissus collilineatus) \\
\hline 8 & Pôster sobre mitos relacionados a serpentes \\
\hline 9 & Biodiorama de periquitamboia (Corallus caninus) \\
\hline 10 & Biodiorama de suaçuboia (Corallus hortulanus) \\
\hline 11 & Biodiorama de jiboia (Boa constrictor constrictor) \\
\hline 12 & Biodiorama de papa-pinto (Pseustes sulphureus) \\
\hline 13 & Biodiorama de jiboia vermelha (Epicrates cenchria cenchria) \\
\hline 14 & Biodiorama de cobra cipó (Philodryas nattereri) \\
\hline 15 & Biodiorama de dormideira (Sibynomorphus neuwidii) \\
\hline 16 & Biodiorama de parelheira (Philodryas patagoniensis) \\
\hline 17 & Biodiorama de muçurana (Clelia quimi) \\
\hline 18 & Biodiorama de boiubu (Philodryas olfersii) \\
\hline 19 & Biodiorama de bicho-pregiça (Polychrus acutirostris) \\
\hline 20 & Aquário de tartaruga-de-orelha-vermelha (Trachemis scripta elegans) \\
\hline 21 & Pôster sobre o ciclo de vida da taturana-de-fogo (Lonomia obliqua) \\
\hline 22 & Biodiorama de papa-vento (Enyalius iheringii) \\
\hline 23 & Biodiorama de briba (Dioploglossus fasciatus) \\
\hline 24 & Biodiorama de jiboia (Boa constrictor amarali) \\
\hline 25 & Biodiorama de cobra-d'água (Liophis miliaris) \\
\hline 26 & Biodiorama de salamanta (Epicrates cenchria crassus) \\
\hline 27 & Biodiorama de cobra-cipó (Tropidodryas striaticeps) \\
\hline 28 & Biodiorama de cobra-bicuda (Oxybelis fulgidus) \\
\hline 29 & Aquário de água doce com oscar e tilápia \\
\hline 30 & Biodiorama de surucucu-do-pantanal (Hydrodynastes gigas) \\
\hline 31 & Biodiorama de píton-indiana (Python molurus molurus) \\
\hline 32 & Biodiorama de cascavel (Crotalus durissus cascavella) \\
\hline 33 & Diorama com réplica de coral verdadeira (Micrurus corallinus) \\
\hline 34 & Biodiorama de cascavel (Crotalus durissus collilineatus) \\
\hline 35 & Biodiorama de falsa coral (Erythrolamprus aesculapii) \\
\hline 36 & Biodiorama de falsa coral (Oxyrhopus guibei) \\
\hline 37 & Biodiorama de cascavel (Crotalus durissus terrificus) \\
\hline 38 & Biodiorama de falsa coral (Oxyrhopus clathratus) \\
\hline 39 & Biodiorama de urutu (Bothrops alternatus) \\
\hline 40 & Biodiorama de cobra-do-leite (Lampropeltis triangulum) \\
\hline 41 & Pôster sobre serpentes não peçonhentas \\
\hline 42 & Biodiorama de caiçaca (Bothrops moojeni) \\
\hline 43 & Biodiorama de caiçaca (Bothrops moojeni) \\
\hline
\end{tabular}


Tabela 5 (cont.). Aparatos da exposição de longa duração do Museu Biológico (IBu).

\begin{tabular}{|c|l|}
\hline Aparato & Descrição \\
\hline 44 & Biodiorama de jararaca-pintada (Bothrops neuwiedi) \\
\hline 45 & Biodiorama de jararaca-pintada (Bothrops neuwiedi) \\
\hline 46 & Biodiorama de jararaca (Bothrops jararaca) \\
\hline 47 & Biodiorama de cotiara (Bothrops fonsecai) \\
\hline 48 & Biodiorama de jararaca-ilhoa (Bothrops insulares) \\
\hline 49 & Biodiorama de jararaca (Bothrops leucurus) \\
\hline 50 & Pôster sobre identificação de animais peçonhentos \\
\hline 51 & Biodiorama de naja (Naje haje) \\
\hline 52 & Biodiorama de jararacuçu (Bothrops jararacussu) \\
\hline 53 & Biodiorama de cobra-do-bambu (Trimeressurus albolabris) \\
\hline 54 & Aquário de água salgada \\
\hline 55 & Biodiorama de píton-bola (Phyton regius) \\
\hline 56 & Biodiorama das estepes (Elaphe dione) \\
\hline 57 & Biodiorama de cobra-do-milho (Elaphe gutatta ) \\
\hline 58 & Biodiorama de caninana (Spilotes pullatus) \\
\hline 59 & Biodiorama de rosemboa (Lichanura radiata) \\
\hline 60 & Biodiorama de cobra-de-duas cabeças (Amphisbaena alba) \\
\hline 61 & Biodiorama de cabeça-de-cobre (Elaphe radiata) \\
\hline 62 & Biodiorama de cobra-de-vidro (Ophiodes fragilis) \\
\hline 63 & Biodiorama de jiboia-do-deserto (Eryx johnii) \\
\hline 64 & Biodiorama de rã (Phillomedusa hipocondrialis) \\
\hline 65 & Biodiorama de salamandra \\
\hline 66 & Pôster sobre artrópodes \\
\hline 67 & Biodiorama de perereca (Phrynohyas venulosa) \\
\hline 68 & Biodiorama de bufo (Chaunus sp.) \\
\hline 69 & Vitrina com ossos (crânios e esqueletos completos de vertebrados) \\
\hline 70 & Biodiorama de aranha-caranguejeira \\
\hline 71 & Biodiorama de aranha-de-jardim (Lycosa sp.) \\
\hline 72 & Biodiorama de aranha-marron (Loxosceles sp.) \\
\hline 73 & Diorama de aranha armadeira (Phoneutria sp.): animais vivos e preservados \\
\hline 74 & Biodiorama de lacraia (Scolopendra sp.) \\
\hline 75 & Biodiorama de escorpião-amarelo (Tityus serrulatus): animais vivos e preservados \\
\hline 76 & Biodiorama de escorpião-marron (Tityus bahiensis): animais vivos e preservados \\
\hline & Vitrina sobre reprodução \\
\hline
\end{tabular}

Tabela 6. Aparatos da exposição temporária “Serpentes das Ilhas de São Paulo" do Museu Biológico (IBu).

\begin{tabular}{|c|l|}
\hline Aparato & Descrição \\
\hline 1 & Pôster introdutório, com mapa \\
\hline 2 & Vitrina com maquete sobre elevação do nível do mar \\
\hline 3 & Pôster sobre a Ilha da Queimada Grande \\
\hline 4 & Diorama com réplica de jararaca-ilhoa (Bothrops insularis) \\
\hline 5 & Pôster sobre a Ilha de Alcatrazes \\
\hline 6 & Diorama com réplica de jararaca-de-Alcatrazes (Bothrops alcatraz) \\
\hline 7 & Pôster sobre as expedições científicas realizadas a essas ilhas \\
\hline 8 & Pôster sobre conservação de serpentes de ilhas \\
\hline
\end{tabular}


Esses aparatos estavam distribuídos em um salão em formato de "U”, com uma única entrada e uma única saída (Figura 13). Entretanto, embora o visitante fosse submetido a um trajeto bastante limitado ao longo da exposição, havia uma relativa liberdade de escolha, sendo observados, em pesquisa anterior, diferentes caminhos estabelecidos por eles: em zigue-zague, em ida e volta parcial e em ida e volta total (BIZERRA et al., 2008a).

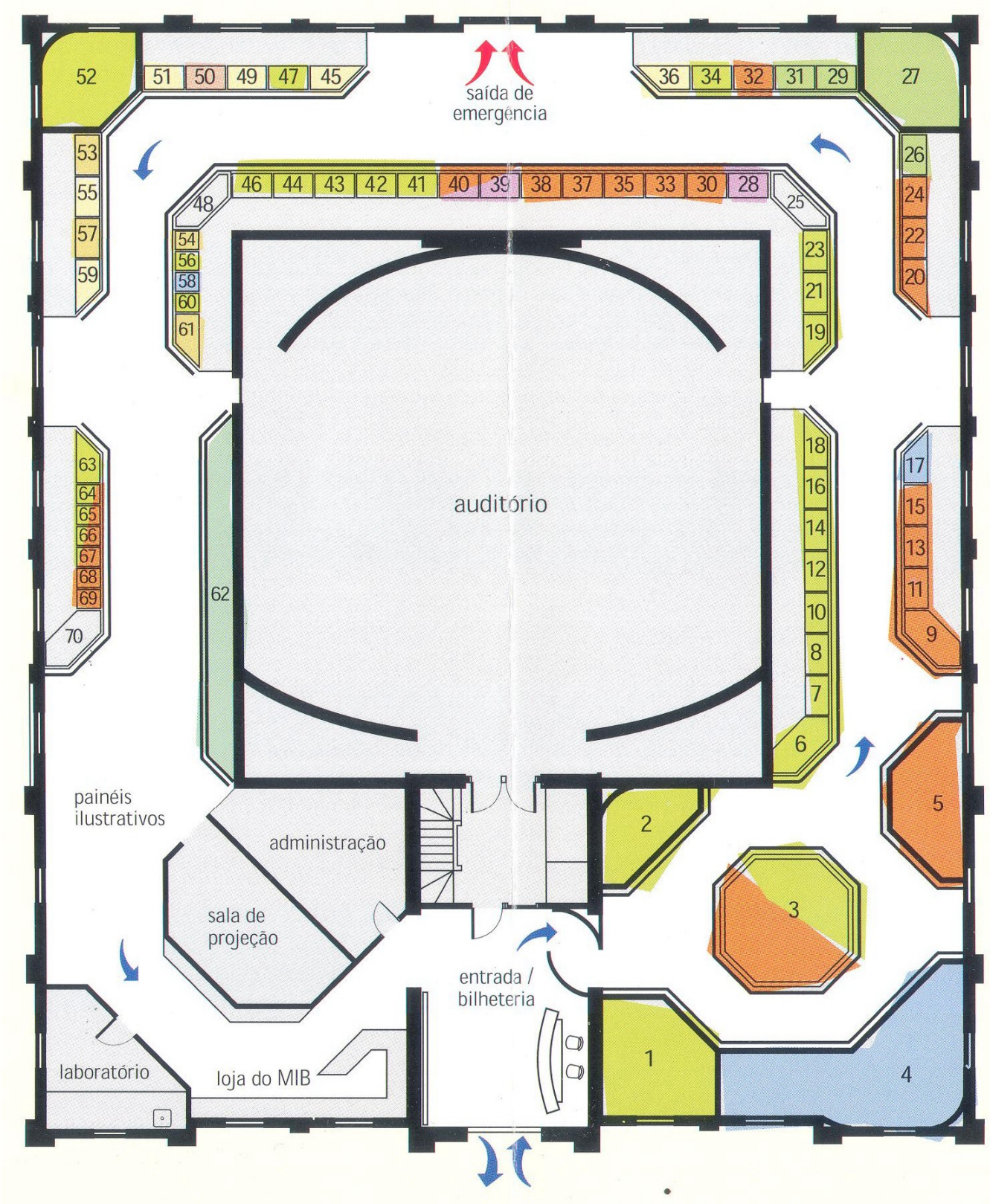

Figura 13 - Croqui do espaço expositivo do Museu Biológico do Instituto Butantan (Fonte: folder de divulgação do Museu - Divisão de Desenvolvimento Cultural/IBu). 


\subsection{A ATIVIDADE DE ENSINO/APRENDIZAGEM PELO OLHAR DO VISITANTE}

Três adultos e uma criança iniciam sua visita ao Museu. Encontram-se no primeiro biodiorama, o recinto das jiboias, situado logo à entrada do salão de exposição. Estão com o cartão de ingresso na mão, que estampa uma cobra coral.

1. Criança: Nossa!

2. Adulto1: Nossa bem!

3. Criança: Essa é a coral.

4. Adulto1: Olha o tamanho dessa cobra!

5. Criança: Essa aqui é qual (apontando para o biodiorama da jiboia)?

6. Adulto2: Essa é a que tá aqui na foto, ó (referindo-se ao cartão de ingresso, com uma coral).

7. Criança: Jiboia (lendo a legenda do biodiorama).

8. Adulto1: É, jiboia.

9. Adulto2: Filha, e é, essa que tá aqui, filha (mostra novamente o cartão).

10. Adulto1: Não, lógico que não.

11. Criança: Não, essa daqui é a coral (referindo-se ao cartão).

12. Adulto2: Aqui em cima, ali, não é, não?

13. Adulto1: Não, mãe, é a coral essa daí.

14. Criança: Coral, olha aqui a coral.

15. Adulto1: Aquela lá é uma jiboia, mãe.

16. Criança: Ji-boi-a!

17. Adulto2: A de cima, ali, ó.

18. Adulto1: É, jiboia, tá escrito aqui, ó (apontando para a legenda).

19. Criança: Jiboia.

20. Adulto2: Eles misturaram... (risos)

21. Adulto1: (risos)

Interações conversacionais como essas são bastante comuns ao longo da visita ao Museu Biológico do Instituto Butantan. A família desenvolve ações de observação dos dioramas, manifestando sensações de admiração ou medo, em que procuram identificar as espécies expostas a partir das legendas da exposição, fazendo associações com saberes que já possuem. A grande maioria dos autores citados anteriormente (Capítulo 1) considera essas elaborações conversacionais como aprendizagem ou evidências de aprendizagem: o visitante, ao estabelecer conexões, lembrar um conhecimento que já possui ou contrapor informações, estaria em processo de aprendizagem. 
Allen (2002), por exemplo, traz em sua análise um grupo de categorias de conversas estabelecidas entre visitantes de museus (perceptiva, conectiva, conceitual, estratégica e afetiva) que permite identificar processos que podem levar à aprendizagem ${ }^{94}$. Aplicando-se essas categorias à sequência de conversas descrita acima, é possível observar que esse grupo faz indicação a elementos expográficos que tenham chamado sua atenção, como a coral e a jiboia (intervenções $6,9,11)$, nomeia os animais expostos (13 a 19) e faz citações, atentando para textos da legenda, por meio da leitura em voz alta $(16,18)$. Para Allen, essas conversas constituem-se como evidências de aprendizagem, pois fazem referência ao ato de identificar e compartilhar aquilo que confere sentido para o visitante em um ambiente complexo como o museu. Outros exemplos poderiam ser facilmente extraídos das conversas registradas nesta pesquisa para exemplificar as demais categorias de evidências de aprendizagem propostas por Allen.

Aqui, também é assumido que essas conversas encontradas são evidências de aprendizagem e que elas se apresentam de diferentes formas, sejam como nomeações, associações com elementos externos, formulação de hipóteses, generalizações, entre tantas outras possibilidades. Nesta perspectiva, os museus são instituições bastante propícias para o desenvolvimento de processos de aprendizagem pois estão repletos de instrumentos humanos, construídos historicamente e portadores de informações, disponíveis às variadas possibilidades de interpretação dos visitantes que estão ali intencionalmente e, geralmente, por vontade própria.

Nesse sentido, pode-se considerar que a análise por categorização das evidências de aprendizagem constitui-se como um método de investigação cuja força está em ressaltar essa diversidade (em riqueza e abundância) de tipos de aprendizagem que podem ocorrer no contexto museal. Em um ambiente com variadas possibilidades de apreensão da realidade, um método que forneça indícios do "que" e do "quanto" um visitante aprende ao interagir com o discurso expositivo torna-se ferramenta importante para qualquer setor educativo interessado em desenvolver estratégias de educação e comunicação mais eficazes.

Entretanto, esse método de análise não é propício quando a intenção do pesquisador é compreender "como" se dá o processo de aprendizagem em museus. Para um entendimento das estratégias utilizadas pelos visitantes para se apropriarem desses "o quê" e "quanto", outras ferramentas de análise tornam-se necessárias. Para captar o movimento do fenômeno

\footnotetext{
${ }^{94}$ Para um melhor entendimento dessas categorias de análise, bem como para a leitura de estudos que, assim como Allen, também empregam essas categorias no contexto museal, ver Garcia (2006) e Sapiras (2007).
} 
de "como" o visitante aprende, as categorias de evidências de aprendizagem não devem ser usadas como lupa para entender os dados, ou seja, o fenômeno a ser compreendido não deve ser analisado por meio das categorias. É necessário que elas sejam usadas como indícios do fenômeno, que o fenômeno seja compreendido a partir delas. Elas não deveriam, portanto, constituir-se como método, mas sim como conteúdo. São elas que apresentam as contradições ao pesquisador, que fornecem indícios do caminho usado pelo visitante nas possíveis transformações dos conflitos em solução.

Nesse sentido, é importante localizar uma unidade de análise que dê conta de colocar essas evidências de aprendizagem em movimento, que consiga captar as transformações do conteúdo analisado, independentemente da escala temporal ou espacial assumida. $\mathrm{O}$ conceito de atividade pode se constituir como uma ferramenta de análise poderosa para o entendimento de um fenômeno como o do movimento do processo de aprendizagem em museus de ciências, pois em atividade, o visitante transforma a realidade objetal em realidade mental.

Mas, qual a relação entre a atividade e a transformação da realidade? Ou, em outras palavras, como a atividade prática se relaciona com o desenvolvimento psíquico? Para Vigotski (2001), ao contrário da opinião científica de sua época, esses dois processos estão fortemente associados e essa união (da atividade prática com processos simbólicos) constituise como um momento fundamental do desenvolvimento intelectual de cada sujeito, em que ocorre uma nova reorganização de seu comportamento. Vigotski vê, portanto, na ação mediada, a força motriz para o desenvolvimento humano.

Nos dois próximos itens, serão trazidos elementos para uma reflexão sobre as interrelações entre atividade e desenvolvimento psíquico, no ambiente museal, focando principalmente as ideias de mediação de Vigotski e formação de conceitos, de Davidov. A escolha desses prismas deu-se baseada no pressuposto de que as pessoas se apropriam da cultura por meio de instrumentos (técnicos ou simbólicos) e através do "outro", sendo, portanto, a mediação (semiótica e social), um processo central em sua interação com o mundo. E, nesse processo mediado, nesse processo de significação das coisas, os indivíduos se constituem, numa transformação do ser biológico em ser cultural, pois, como sugere Vigotski, é o processo de aprendizagem das coisas, uma ação mediada, que promove o desenvolvimento psíquico, o desenvolvimento das funções superiores, características dos seres humanos. 
Um dos processos fundamentais encontrados por Vigostki para relacionar a aprendizagem ao desenvolvimento é a formação do pensamento por conceito. Como traz Giordan (2006, p. 29):

ao mencionar o pensamento por conceitos, Vigotski o toma como uma nova forma de atividade intelectual, um novo modo de conduta, um novo mecanismo intelectual, que se diferencia de outras atividades por ser uma função com estrutura e composição próprias. Na adolescência, a passagem ao pensamento por conceitos está vinculada à inserção do sujeito no mundo da consciência social objetiva, no mundo das ideologias sociais, como ciência, arte, religião e outras esferas ideológicas, cujas correspondências com a realidade objetiva se desenvolvem por meio de sínteses abstratas peculiares, ou seja, por meio de sistemas conceituais construídos historicamente (GIORDAN, 2006, p. 29).

Com esses pressupostos em mente, foram analisadas as conversas de três grupos de visitantes que se apresentaram com características distintas entre si. A primeira família, denominada de G4, era composta por quatro pessoas: a mãe Tatiana, uma veterinária de 31 anos, seus dois filhos Henrique (10 anos, cursando o Ensino Fundamental) e Sofia (03 anos, frequentadora de creche), e sua mãe Beatriz, de 54 anos. A visita se deu no dia 19 de janeiro de 2007 e teve duração de 73 minutos. A família residia na cidade de São Paulo e se considerava público assíduo de museus. Essa era a primeira visita ao Instituto Butantan e as expectativas variaram dentro do grupo: enquanto Tatiana e Beatriz queriam propiciar momentos de aprendizagem para as crianças, Henrique estava disposto a saber mais sobre as aranhas e Sofia gostaria de "ver muitos bichos".

Já a segunda família, a G6, era composta por três visitantes: Maria Lenise, psicóloga e enfermeira de 50 anos, seu filho Guilherme, de 09 anos, e sua prima Rita, advogada de 60 anos. Mãe e filho residiam em Florianópolis, Santa Catarina, e a prima, em São Paulo. A família tinha como hábito frequentar museus em uma média de três visitas anuais, com o intuito de "saber a história, para saber como é que as coisas surgem" e se informar "sobre as últimas novidades das pesquisas". Seus conceitos de museu eram bastante amplos: Maria Lenise definia essas instituições como "o templo do tempo" e Rita considerava zoológicos e edificações tombadas como "museus a céu aberto". Enquanto Maria Lenise e Guilherme visitavam pela primeira vez o Museu Biológico do Instituto Butantan, Rosa já o havia feito numerosas vezes. Para eles, esse Museu representava o Instituto Butantan e deveria apresentar tópicos relacionados à saúde pública e expor "a importância dele para a pesquisa". Essa visita, realizada no dia 01 de fevereiro de 2007, com duração de 45 minutos, foi sugerida por Rita a seus primos que estavam de férias na cidade de São Paulo como um "passeio interessante e 
instrutivo". Mãe e filho estavam ansiosos para ver "muita cobra, muita aranha, muito escorpião" e "a extração do soro (sic)", especialmente a técnica para a retirada do veneno.

A família G7, composta por Neusa, uma mulher de 42 anos, suas duas filhas (Ana Luiza, 08 anos, e Diane, 24 anos) e seu genro (Anderson, 26 anos), fez a visita ao Museu em 07 de fevereiro de 2007, em um tempo total de 58 minutos. Os membros da família residiam em Vargem Grande Paulista, município pertencente à Região Metropolitana de São Paulo, e, nessa primeira visita ao Museu Biológico, tinham o intuito de "ter um pouco de lazer" e "conhecer espécies de cobras" e a expectativa de "ter explicações sobre animais vivos" (Diane e Neusa afirmaram que ao pensar no Museu Biológico, mesmo sem o conhecer, o que vinha à mente eram os animais vivos). A filha menor, Ana Luiza, cursava a $3^{\text {a }}$ série do Ensino Fundamental. Sua mãe, Neusa, era graduanda em Ciências Contábeis e sua irmã (a pastora Diane) e seu cunhado eram graduados em Teologia. A família relatou que visitou dois museus durante o último ano, citando o MASP e um museu histórico em Recife (PE). Não se consideravam frequentadores de museus, mas quando o faziam era para "conhecer mais" e “combater a ignorância". A imagem de "museu" nessa família correspondia a um edifício com "esculturas, objetos, pinturas", sem interatividade, onde as pessoas poderiam fotografar, ler legendas, divertir-se e se informar. Para Diane, o museu era um local onde não se pode tocar nos objetos, o que limitaria seus desejos: "Sei que não pode tocar nos objetos, mas eu gosto". Entre as ações colocadas para a família selecionar quais seriam possíveis de ocorrer durante uma visita a museus, aprender, pensar, perguntar e conversar com amigos e parentes não foram ações consideradas como relacionadas a esses ambientes.

Com as transcrições das falas desses grupos, foram extraídos episódios que apresentaram uma estrutura interna organizada. Entende-se aqui o episódio, segundo a definição de Carvalho (1996), como um conjunto de ações que desencadeia um processo de busca de respostas para um determinado problema. Cada episódio é composto por momentos em que fica evidente uma situação a ser investigada. Nesta pesquisa, assumiu-se cada um deles como uma sequência de fases perceptíveis. Assim, um episódio inicia-se com uma proposta de engajamento (um questionamento inicial, um convite, uma afirmação) por um dos membros, que promove um posicionamento dos demais sujeitos, que se engajam num movimento explanatório (contextualização do problema, busca de soluções, colocações de opiniões), sejam ou não em concordância com a proposta. O episódio se encerra não necessariamente com uma conclusão ou solução, mas quando há o silenciamento do tema dentro do período analisado (pressupõe-se que o visitante não inicia e encerra sua 
compreensão sobre um determinado assunto durante uma vista ao museu, mas sim, que ela faz parte de um processo contínuo de reflexão sobre o mundo, que a visita é um elo na cadeia do desenvolvimento psíquico do indivíduo). Nesse sentido, um episódio foi selecionado para a reflexão com ênfase na mediação em museus e outros dois, no desenvolvimento de conceitos nesses ambientes.

\subsubsection{Mediação semiótica e mediação social}

O trecho de conversação apresentado na epígrafe foi desenvolvido pelos membros da família G7. Nessas conversas, vê-se uma estratégia desenvolvida por visitantes de museu para resolver um problema colocado logo que entram nesses espaços: interpretar os sistemas simbólicos utilizados em sua comunicação visual. Cada museu apresenta uma forma de expor seus objetos, com legendas, ícones ${ }^{95}$, símbolos que representam determinados conteúdos selecionados pela instituição. Nas legendas dos biodioramas do Museu Biológico, por exemplo, encontra-se um conjunto de ícones (desenhos gráficos sintéticos) e símbolos (palavras) que significam informações biológicas e ecológicas da espécie exposta (Figura 14). A viviparidade e a oviparidade, nesse caso, são representadas por desenhos gráficos de uma serpente com filhotes ao seu redor e de uma serpente com ovos e alguns filhotes, respectivamente.

\footnotetext{
${ }^{95}$ Nesta investigação, utiliza-se o termo ícone como empregado no campo do Design (e não da Semiótica), em que corresponde a uma figura simples, fácil de ver e entender, utilizada para expressar uma ideia sem palavras (como encontrado nas figuras de computador - pasta, tesoura, ampulheta, nos sinais de masculino e feminino ou nos avisos gráficos sintéticos dos aeroportos) (LUPTON; PHILLIPS, 2008; SANTAELLA, 2005).
} 


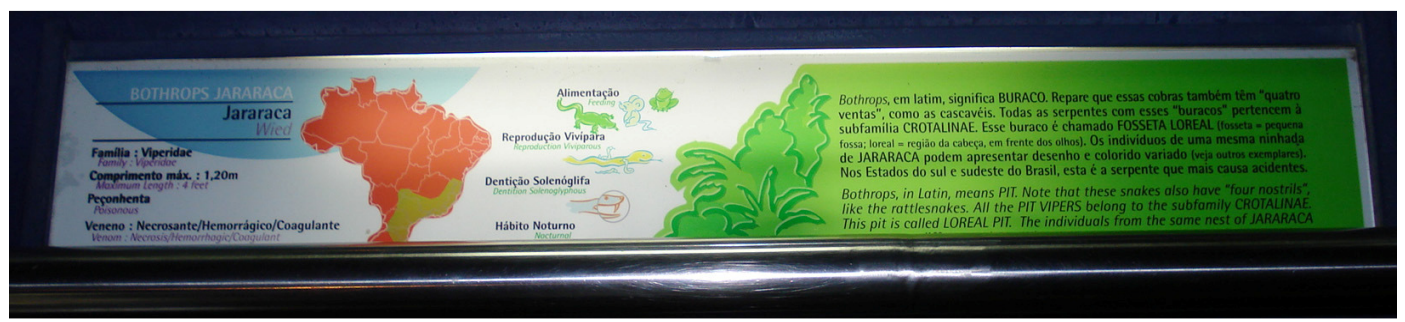

a.

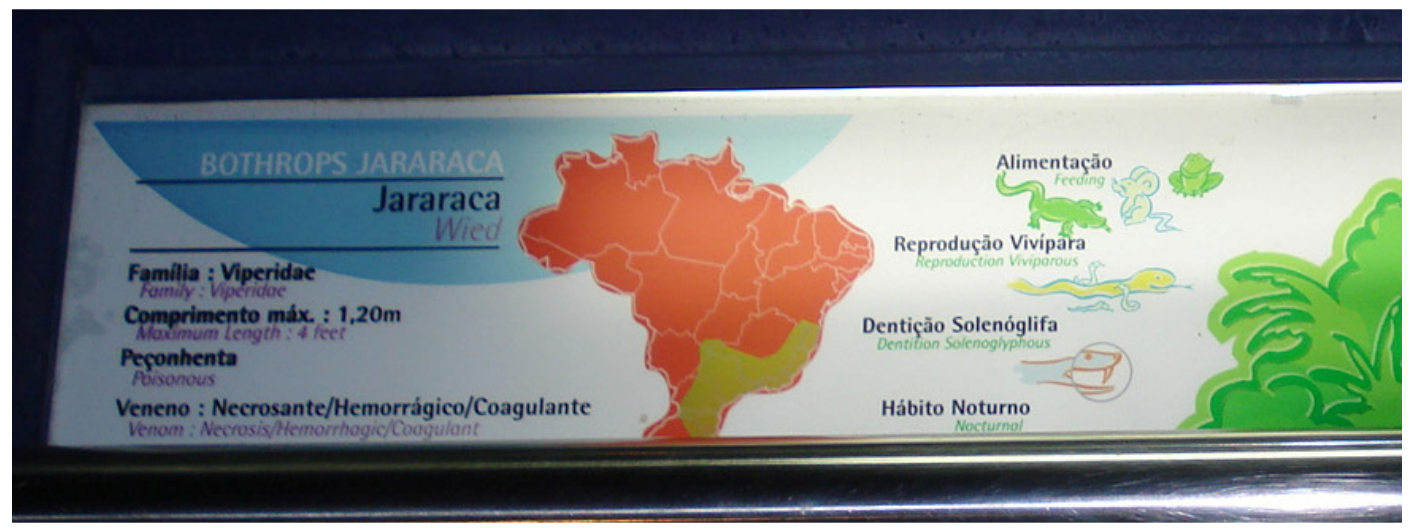

Figura 14 - Legenda do biodiorama de jararaca a) completa e b) em detalhe (Foto: Alessandra Schunck).

Os visitantes lançam mão, portanto, de uma estratégia de apreensão da realidade que, dialeticamente, constitui o homem, tanto em sua filogenia quanto sua ontogenia: o uso de ferramentas para solucionar um dado problema. Como aponta Vigotski (2007), o homem se relaciona com o mundo principalmente de uma forma mediada, indireta.

Assim, o ser humano, ao conhecer o mundo, desenvolve uma atividade que pressupõe uma relação entre três elementos: o sujeito que conhece, o objeto a conhecer e o mediador que possibilita o conhecimento. Essa ação mediada é vista como uma substituição do processo simples de estímulo e resposta direta a uma situação-problema $(\mathrm{S}-\mathrm{R})$, por um ato complexo que requer um elo intermediário $(S-X-R)$.

Em seus estudos sobre as funções psicológicas superiores, em que procurava identificar os complexos mecanismos de controle do pensamento e da ação intencional, Vigotski encontrou no signo um importante aliado. Assim como Marx e Engels enfatizaram o 
papel dos instrumentos técnicos na mediação do homem com o mundo, Vigotski fez dos signos os mediadores das relações dos homens entre si, ressaltando que instrumentos técnicos e signos assemelham-se, principalmente, porque ambos possuem essa função mediadora. Para Pino (2005, p. 137, grifo do autor), “a grande descoberta de Vigotski, não foi o signo propriamente dito, do qual se fala desde a época grega, [...], mas a sua natureza e função em paralelo com a natureza e função do instrumento na teoria do trabalho social de Marx e Engels".

Entretanto, Vigotski ressaltou as diferenças entre instrumento e signo. O primeiro é elo entre o trabalhador e o objeto de seu trabalho, é orientado externamente e, necessariamente, leva a modificações no objeto. "Constitui o meio pelo qual a atividade humana externa é dirigida para o controle e domínio da natureza" (Vigotski, 2007, p. 55). Já o segundo é orientado internamente e não modifica o objeto da atividade. Ele é um meio da atividade interna, dirigido para o controle do próprio sujeito. O elemento mediador, nesse caso, pressupõe o engajamento ativo do indivíduo em seu estabelecimento e, também, em uma ação reversa, a sua ação sobre o sujeito:

\begin{abstract}
na medida em que esse estímulo auxiliar possui a função específica de ação reversa, ele confere à ação psicológica formas qualitativamente novas e superiores, permitindo aos seres humanos, com o auxílio de estímulos extrínsecos, controlar seu próprio comportamento. $\mathrm{O}$ uso de signos conduz os seres humanos a uma estrutura específica de comportamento que se destaca no desenvolvimento biológico e cria novas formas de processos psicológicos enraizados na cultura (Vigotski, 2007, p. 34, grifo do autor).
\end{abstract}

Vale ressaltar que o fato dos signos constituírem-se como elementos mediadores de orientação interna não se relaciona com a estrutura desse elemento: ele pode apresentar-se tanto como marcas externas como processos internos. Como coloca Oliveira (2006), ao longo da história humana, os signos são utilizados nas mais variadas situações. Em sua forma mais elementar, o signo é uma marca externa, que auxilia o homem em processos como a memória e a atenção. Dobrar a manga da camisa para lembrar de telefonar a alguém, fazer uma lista de compras por escrito, usar o guia de ruas para chegar a uma festa são alguns exemplos de uso de signos como marcadores externos em situações diversas.

Entretanto, tanto na história da espécie, em sua filogenia, quanto na história do indivíduo, em sua ontogenia, ocorrem mudanças fundamentais no uso dos signos, sendo o processo de internalização um dos mais representativos. Ao longo do desenvolvimento humano, as marcas externas deixam de ser necessárias e o sujeito passa a utilizar signos internos: "ocorre o que chamamos de internalização; os signos externos, de que as crianças 
em idade escolar necessitam, transformam-se em signos internos, produzidos pelo adulto como um meio de memorizar" (Vigotski, 2007, p. 40).

Os signos externos, ao serem internalizados, constituem-se então como representações mentais que substituem os objetos da experiência sensorial. Como coloca Oliveira (2006, p. 35), "assim como um nó num lenço pode representar um compromisso que não posso esquecer, minha ideia de 'mãe' representa a pessoa real da minha mãe e me permite lidar mentalmente com ela, mesmo na sua ausência".

Ao lidar com representações mentais, que substituem o real imediato, o sujeito passa a ter a liberdade de se desprender do tempo e do espaço presentes, sendo possível planejar, imaginar, lembrar na ausência e intencionar. Essa ideia de libertação do ser humano das impressões imediatas está contida na definição precisa e sintética de signo feita por Peirce (1996 apud PINO, 2005, p. 127, grifo do autor): "um signo, ou Representamen, é algo que, sob certo aspecto ou de algum modo, representa alguma coisa para alguém”.

Dessa forma, ao promover a união entre atividade prática e signo, Vigotski estabelece relações entre comportamento e desenvolvimento psíquico: o controle da ação prática pelo signo confere ao ser humano a autodeterminação, o poder de tomada de decisões. Entretanto, o signo, antes de permitir o controle individual, já foi um controle social, ou seja, foi algo exercido pelo outro. Assim, como ressalta Giordan (2006), a mediação dos signos passa a ser o elemento que estabelece a ligação entre o plano social e o plano interno.

É necessário ressaltar que, para Vigotski, existe uma história natural da operação com signos. As operações simbólicas, mediadas, não surgem como resultado da lógica pura, nem tampouco são inventadas ou descobertas pelos sujeitos, como "um súbito rasgo de discernimento ou de uma adivinhação rápida como um raio (a assim chamada reação do 'aha')" (Vigotski, 2007, p. 41). Para o autor, as operações com signos são resultados de um processo prolongado e complexo:

isso significa que a atividade de utilização de signos nas crianças não é inventada e tampouco ensinada pelos adultos; em vez disso, ela surge de algo que originalmente não é uma operação com signos, tornando-se uma operação desse tipo somente após uma série de transformações qualitativas. Cada uma dessas transformações cria as condições para o estágio seguinte e é, em si mesma, condicionada pelo estágio precedente (Vigotski, 2007, p.41, grifo do autor).

Assim, as operações com signos não são prontamente estabelecidas pelos sujeitos. Elas percorrem um caminho de transformações, fazem parte de um mesmo processo, mas como estágios diferentes. Para o autor, baseado nos estudos de Leontiev sobre memorização, 
crianças pequenas apresentam estágios intermediários de operação com signos e somente na idade escolar começam a se utilizar propositadamente de signos externos, de forma instrumental. Mas é na adolescência que o processo de internalização dos signos irá realmente se efetivar, podendo o sujeito operar eficazmente sem a presença de marcas externas.

Em trechos extraídos das falas estabelecidas pela família G4, é possível perceber diferentes momentos da operação com signos, quando se analisa o domínio da mãe Tatiana na interpretação de símbolos e o estágio mais elementar de operação com signos de sua filha Sofia (de três anos). Nesse episódio, o Episódio 1 (E1), que inclui vários momentos da visita, Tatiana se dispõe a ensinar Sofia a compreender o interpretante das imagens sintéticas usadas nas legendas do museu:

Tatiana dirige-se ao biodiorama da periquitamboia e chama sua filha Sofia:

1. Tatiana: Vem cá Sofia, vem ver esse. Olha aqui no galho. Ela dormindo no galinho.

2. Beatriz: Que linda, olha essa aqui que linda!

3. T: Tem duas aqui, a verdinha, nenê. Ó, essa vive nas árvores. Aqui filha.

4. B: Essa, essa tinha lá em (?), nossa é parecida demais (?).

5. T: Aqui meu amor, ela tá indo pro lado ao redor do galho, ó lá, tá vendo? Achou? Cê viu ela parece uma folha escondidinha, daí, quando ela tá assim nas árvores a gente não consegue ver ela. Acho que ela quer, vamo ver o que ela quer. Ó as coisas que ela come. O que tá desenhado são as coisas que ela come.

6. Sofia: Morcego, rato, cobra ("lendo" a parte da legenda sobre viviparidade).

7. T: Ah, não, aqui é como ela se reproduz, ó, ela tem filhotinhos, a mamãe cuida dos filhotinhos, tá vendo?

8. S: Mas cadê os filhotinhos dela?

9. T: Não tão aqui não, aqui ela vem, vive sozinha e ó, ela gosta de andar de noite tá vendo? 10. S: É... ó, e ela come isso também (apontando para o ícone representando a dentição).

11. T: É, ela tem dentes.

12. S: Ela come tubarões?

13. T: Será? Não, não... aqui não é... aqui é a carinha dela, amor. Quer dizer que os dentinhos dela são, devem ser parecidos, ó, talvez seja uma coisinha de tubarão. Vem, vamos ver as outras?

14. S: Olha aqui mamãe!

15. T: E essa cobra gorda? Encostadinha na parede. Olha, tem duas, uma aqui ó, e outra lá.

16. S: O que ela come? Morcego, rato, passarinho, o filhinho dela aqui e de novo.

17. T: Ela gosta de dormir também. Ela gosta de dormir de dia.

18. S: E aqui ó...

19. T: Outra árvore.

20. S: E aqui ó? 


\section{T: Essa é a jiboia.}

22. S: Ela come passarinho, rato, peixe... ela come cobra?

23. T: Não querida, aqui é como ela vive, ela tem os filhotinhos dentro da barriga da mamãe ó. As cobras podem ter filhotinhos dentro da barriga da mamãe ou por ovos. Deve ter alguma por aqui que põe ovos (procura em outras legendas alguma representação de oviparidade). Ah, vem cá, achei uma que põe ovos, ó. Essa põe ovos, ó. Olha, tá vendo? Os bebês nascem dos ovinhos. Olha essa cobra, que cobrona... Tá vendo, caramujo...

24. S: Caramujo.

25. T: Caramujo e concha.

26. S: Cadê a cobra?

27. T: Ó a cobrinha cipó, ó aqui Sofia. Vem vê essa cobra. Aqui, essa aqui que tá dormindo. 28. S: Olha aqui mamãe, essa é bem pequenininha. Mãe, vem ver mamãe. Mamãe, vem ver, mamãe. Mamãe... vem, vem...

28. T: (?) iguana.

29. S: Mãe, aqui mãe! Ai que bonitinha... (puxando a mãe para outro biodiorama).

30. T: E essa, como que ela nasce, nasce da barriga da mamãe ou dos ovos?

31. S: Dos ovos!

32. T: Ela come de dia ou de noite?

33. S: De dia!

34. T: Como ela come?

35. S: Humm... passarinho, sapo, rato...

36. T: Isso mesmo, e aqui?

37. S: Uma carinha... (sobre a dentição)

38. T: Aí aqui ó, tem um dente diferente, tá vendo? Tem um dente maior. Ó tá vendo o filhotinho, dorme aqui dentro. Ó Sofia, (apontando para uma outra legenda, com desenhos gráficos de áreas florestadas) aqui, ó, meu amor, aqui é floresta, bem fechada e aqui...

$\mathrm{Na}$ explicação (5) de Tatiana, ela introduz à Sofia que a legenda do museu contém informações sobre o animal exposto, chamando sua atenção para o fato de que, por meio dos ícones apresentados, é possível saber o que aquela serpente come, como se reproduz, em qual período do dia é mais ativa, como é sua dentição e em qual ambiente vive. Sofia engaja-se na proposta sugerida por sua mãe, na tentativa de compreender esses ícones e, rapidamente, identifica os elementos que the são familiares (6). Entretanto, aqueles que não são imediatamente identificados, são associados às generalizações já feitas por Sofia anteriormente. Na fala 12, por exemplo, provavelmente somou a imagem da cabeça da serpente (cuja finalidade era apresentar a dentição do animal) ao núcleo do complexo "tubarão" que ela já havia estabelecido antes de sua visita ao museu. Essa construção refere-se 
ao que Vigotski (2000) denominou de complexo associativo. A criança, que nessa faixa etária começa a desenvolver o pensamento por complexos, acrescenta ao objeto nuclear de um complexo outro objeto que tenha, por exemplo, a mesma cor ou forma, em uma generalização fatual, como se possuíssem o mesmo "nome de família". Nesse momento do desenvolvimento, a criança não opera com conceitos, mas com complexos. Estes se baseiam em vínculos objetivos, que se revelam na experiência imediata, sem a utilização de signos.

Com ajuda de sua mãe, que possui total domínio de operação com aqueles signos, Sofia tem a possibilidade de formar novos complexos, até então não experimentados, com a formação de vínculos objetivos. Nas conversas 13 e 38, Tatiana chama a atenção de Sofia para alguns traços do ícone que permitem identificá-lo como uma cabeça de serpente (com dentes) e não com um tubarão. O mesmo ocorre com o ícone sobre viviparidade. Para Sofia, qualquer desenho de serpente na legenda representa a dieta da cobra exposta (22). Entretanto, Tatiana novamente intervém e seleciona os atributos da imagem que lhe conferem o caráter de filhote de cobra e não de dieta de cobra. Em outra passagem, Sofia ainda não construiu um objeto nuclear ao qual pudesse associar a nova imagem observada, a de filhote de cobra:

1. S: Olha aqui mãe, olha aqui mamãe.

2. T: Que lindinha, será que ela sente o calor da minha mão (colocando a mão no vidro, próximo à serpente)?

3. S: Mãe?

4. T: Ah?

5. S: Vamo vê o que ela come mãe? Ô mãe, vamo vê o que ela come mãe?

6. T: O que ela come?

7. S: É... Lagarto, cobra.

8. T: E outras cobras.

9. S: E ela, e a cobra nasce do ovo... e da barriga da mamãe (apontando para os desenhos de serpentes que se referem à dieta ofiófaga).

10. T: Não ela só nasce do ovo.

11. Henrique: Aqui é o que ela come.

12. S: De dia. Ela vive de dia. E ulha, ulha ela aqui fechada dela...

No trecho acima, Sofia é colocada à frente a uma situação conflituosa: ora o desenho de cobra referia-se à dieta, ora à reprodução. Mas, como aponta Vigotski (2000), nesta fase, as crianças não possuem juízo do que é contraditório, pois para elas não há ainda uma hierarquização conceitual. Os complexos estão todos no mesmo plano, um não está subordinado a outro. 
No trecho final do episódio referente ao reconhecimento dos ícones das legendas, Sofia aproxima-se de uma legenda, desacompanhada de sua mãe, e, sozinha identifica rapidamente os ícones expostos. A seguir, chama sua mãe:

1. S: Na barriga da ma... (sozinha, lendo legenda). Mãe, vem essa daqui... aqui mamãe (puxa a mãe para o diorama). Aqui ó, come sapo, rato, lagarto, nasce da barriga da mamãe, não tem um dentão, vive de noite e vive na floresta fechada.

2. T: Isso mesmo.

3. Beatriz: Venha ver essa cobra.

4. T: Aqui é quase tudo igual, essa aqui é diferente ó, pode andar de dia e pode andar de noite. Ela pode... andar de dia ou de noite. E ela gosta de árvores, ó, porque ela é amarelinha, gosta de morar no tronco. Ela mora numa ilha.

5. S: E ela come tudinho isso aqui...

Se somente essa intervenção de Sofia (1, trecho acima) fosse considerada, seria possível imaginar que ela, ao final do episódio, já apresentava condições de operar com signos, ou seja, de resolver as situações conflituosas, de compreender que o ícone registrado na legenda representava que aquela serpente observada alimentava-se de determinada presa, reproduzia-se de determinada forma e possuía determinada dentição. Entretanto, analisada em conjunto com as demais falas e com os gestos registrados em vídeos, é necessário compreender esses dados de outra forma.

Ao se aproximar de um biodiorama, Sofia praticamente não olhava para a serpente. Sua atenção estava totalmente direcionada para a leitura das legendas. Com o que Sofia interagia, com a serpente ou com a legenda? O problema posto a Sofia não era compreender a história natural do animal, mas sim entender cada um daqueles ícones. Para a mãe de Sofia, o ícone era um signo, que representava algo ausente. $\mathrm{O}$ ícone era o mediador entre Tatiana e o e a concepção que ela tinha de morcego, a dieta ausente da serpente. O signo informava-lhe que há oviparidade e viviparidade, lembrava-lhe que as serpentes vivem em áreas abertas ou florestadas. Entretanto, para Sofia, o ícone parecia constituir-se como o objeto direto de sua experimentação. Era ele o objeto que Sofia observava, levantando traços e estabelecendo vínculos.

Como coloca Vigotski (2007, p. 46, grifo do autor), "a capacidade de formar associações elementares não é suficiente para garantir que a relação associativa possa vir a preencher a função instrumental necessária à lembrança", até mesmo porque Sofia não 
desenvolveu ainda uma sistematização conceitual que lhe permita "formar" e "lembrar" de muitos dos conceitos científicos trazidos pela exposição (viviparidade, dentição, hábitat).

Para Vigotski (2007), a criança começa a usar signos somente por volta dos oito anos. Antes disso, interage com o objeto de forma direta. Nesse sentido, é possível concluir que Sofia interagiu com o ícone, com a imagem sintética apresentada na legenda e não com o conceito exposto no museu. Aquilo que é signo para sua mãe é objeto para ela. Mãe e filha estão, portanto, em momentos diferentes na cadeia de operação com signos: enquanto Tatiana opera instrumentalmente com o signo, Sofia encontra-se em um estágio intermediário de operações, entre o elementar e o instrumental, operações estas que, posteriormente, se desenvolverão completamente mediadas.

Mas qual a importância dos museus nesse fenômeno? Se as crianças estão em processo de desenvolvimento do pensamento por complexos cotidianamente, qual a especificidade do museu que acrescenta algo a esse processo? Aqui, mais uma vez, não pode ser negligenciado o papel do objeto museal. Como já dito, esses objetos carregam historicidade humana e, ao serem expostos em locais específicos, conferem ao visitante a possibilidade de interação com diferentes saberes humanos, de forma "concentrada" e, principalmente, organizada. Lembrando as palavras de Vigotski (2007, p. 20, grifo nosso):

Desde os primeiros dias de desenvolvimento da criança, suas atividades adquirem um significado próprio num sistema de comportamento social e, sendo dirigidas a objetos definidos, são refratadas através do prisma do ambiente da criança. O caminho do objeto até a criança e desta até o objeto passa através de outra pessoa. Essa estrutura humana complexa é o produto de um processo de desenvolvimento profundamente enraizado nas ligações entre história individual e história social.

Nos museus, esse direcionamento da atividade da criança a objetos definidos passa a ser ponto interessante, pois sua estruturação, sua diversidade de acervos, sua intencionalidade em comunicar o patrimônio organizam o saber humano de tal forma que contribuem para constituir os objetos museais como possíveis objetos de atividades. O sujeito que, por exemplo, tem a necessidade de se aproximar da pintura contemporânea brasileira ou das últimas descobertas científicas sobre os dinossauros poderá encontrar em um museu de arte contemporânea ou em um de paleontologia boas possibilidades de desenvolver uma atividade de aprendizagem que satisfaça a sua necessidade.

Nesse direcionamento para o objeto, as interações sociais tornam-se cruciais. É na relação com o outro, mediada pelos signos, que o sujeito se constitui. Quando o indivíduo 
nasce culturalmente, o caminho que leva da criança ao mundo e deste à criança, passa pelo outro, que se torna mediador entre a criança e o mundo. A mediação semiótica e a mediação social tornam-se imprescindíveis para a formação do ser cultural. Na medida em que suas ações recebem significação dada socialmente, a criança incorpora a cultura que a faz humana. Isso não ocorre de forma passiva, pois é a sua ação que constitui a razão e a origem da ação do outro. Assim, o desenvolvimento do indivíduo passa necessariamente pelo social, em um processo contínuo e prolongado:

todas as funções no desenvolvimento da criança aparecem duas vezes: primeiro, no nível social, e, depois, no nível individual; primeiro, entre pessoas (interpsicológica), e, depois, no interior da criança (intrapsicológica). Isso pode se aplicar igualmente para a atenção voluntária, para memória lógica para formação de conceitos. Todas as funções superiores originam-se das relações reais entre os indivíduos humanos (Vigotski, 2007, p. 58).

Nesse posicionamento do autor, fica claro que seu conceito de social não se opõe ao de indivíduo, pois estabelece um vínculo entre as operações mentais de diferentes sujeitos. Como coloca Giordan (2006. p. 23), Vigotski vê o social como oposto ao natural, ao biológico, mas “essa oposição deve ser entendida na perspectiva de um pensamento dialético e não dualista, ou seja, que o desenvolvimento cultural, por ser um processo histórico, não prescinde do biológico, não o elimina, mas supera-o, transforma-o para que seja agregado à ontogênese".

Nesse sentido, a dimensão sociocultural não se apresenta, nas ideias de Vigotski, como um pano de fundo onde o indivíduo atua, não se constitui somente no local onde mora ou em seu nível socioeconômico. Para ele, as relações são mais complexas: é o grupo cultural onde o indivíduo se desenvolve que lhe fornecerá formas de perceber e organizar a realidade, ou seja, os instrumentos psicológicos mediadores na sua relação com o mundo. Em outras palavras, é o grupo que lhe fornecerá um ambiente estruturado, repleto de elementos carregados de significados. Entretanto, é a partir de sua experiência objetiva e do seu contato com as formas culturalmente determinadas de organização do real, que o indivíduo constrói o seu próprio sistema de signos para interpretar o mundo. Como ressalta Oliveira (2006, p. 37), “os grupos culturais em que as crianças nascem e se desenvolvem funcionam no sentido de produzir adultos que operam psicologicamente de uma maneira particular, de acordo com os modos culturalmente construídos de ordenar o real".

O processo de aprendizagem, em que o individuo se apropria da cultura (habilidades, informações, valores, atitudes, etc.) a partir de seu contato com o mundo por meio do outro, e cria novas possibilidades de interação, torna-se elemento chave no processo de constituição 
do sujeito. Mas, se para aprender é necessário ter conhecimento anterior para dar significado àquilo com que o sujeito interage, como se inicia esse processo? Vigotski oferece um caminho para a resposta:

assim como você não pode aprender a nadar parado na praia [...] para aprender a nadar, você deve, forçosamente, mergulhar na água, mesmo que não saiba nadar, de modo que a única maneira de aprender alguma coisa, de adquirir conhecimentos, é fazendo algo, em outras palavras, adquirindo conhecimento (VYGOTSKY, $1997^{96}$ apud DANIELS, 2003, p. 51).

É, portanto, na atividade, movida pela necessidade de se inserir no mundo cultural, que a criança apropria-se de sua cultura. Para Vigotski, um mecanismo de ação importante para que o indivíduo se aproprie dos elementos da cultura disponíveis a ele no seu cotidiano é o da imitação. A imitação pressupõe ação e ao agir, a criança confere à sua ação o significado dado pelo outro. A importância desse processo, não como cópia mas como reconstrução individual daquilo que é observado no outro, é evidente nesta fala do autor:

na criança, ao contrário [do animal], o desenvolvimento decorrente da colaboração via imitação, que é a fonte do surgimento de todas as propriedades especificamente humanas da consciência, o desenvolvimento decorrente da aprendizagem é o fato fundamental. Assim, o momento central para toda a psicologia da aprendizagem é a possibilidade de que a colaboração se eleve a um grau superior de possibilidades intelectuais, a possibilidade de passar daquilo que a criança consegue fazer para aquilo que ela não consegue por meio da imitação. Nisto se baseia toda a importância da aprendizagem e é isto o que constitui o conteúdo do conceito de zona de desenvolvimento imediato. A imitação, se concebida em sentido amplo, é a forma principal em que se realiza a aprendizagem sobre o desenvolvimento (Vigotski, 2001, p. 331).

Para Vigotski, o sistema educativo deveria ensinar à criança não aquilo que ela pode fazer sozinha, mas aquilo que ainda não sabe e que lhe vem a ser acessível com a ajuda do outro. Por isso a zona de desenvolvimento imediato, que determina esse campo das transições acessíveis à criança, representa um elemento fundamental na relação da aprendizagem com o desenvolvimento:

a investigação demonstra sem margem de dúvida que aquilo que está situado na zona de desenvolvimento imediato em um estágio de certa idade realizase e passa ao nível do desenvolvimento atual em uma segunda fase. Noutros termos, o que a criança é capaz de fazer hoje em colaboração conseguirá fazer amanhã sozinha. [...] Na fase infantil, só é boa aquela aprendizagem que passa a frente do desenvolvimento e o conduz (Vigotski, 2001. p. 331-2).

\footnotetext{
${ }^{96}$ Vygotsky, L. S. Educational Psychology. Boca Raton: St. Lucie Press. 1997.
} 
Entretanto, para o autor, só é possível ensinar à criança aquilo que ela já for capaz de aprender. É necessário reconhecer o "limiar inferior da aprendizagem": é possível a aprendizagem onde é possível a imitação. Isso não significa, contudo, que o desenvolvimento deva percorrer ciclos estabelecidos, que seja necessário "preparar inteiramente o solo em que a aprendizagem irá construir seu edifício". É necessário estabelecer também o "limiar superior da aprendizagem. Só na fronteira entre esses dois limiares a aprendizagem será fecunda" (Vigotski, 2001, p. 333). É necessário, portanto, perceber qual é a distância entre o nível de desenvolvimento real, imediato (geralmente determinado pela resolução independente de problemas) e o nível de desenvolvimento potencial (determinado pela resolução de problemas em parceria com o outro), ou seja, a zona de desenvolvimento imediato.

Com as elaborações conversacionais entre Tatiana e sua filha Sofia, no episódio transcrito anteriormente, é possível exemplificar a importância dessas ideias para o processo de ensino/aprendizagem também em museus de ciências. Foi Tatiana quem direcionou e conduziu a atenção de Sofia para aquilo que, entre todas as possibilidades de experiência objetiva, seu grupo familiar julga culturalmente mais importante. Ao decidir priorizar a interpretação das legendas, Tatiana introduz Sofia naquilo que seu grupo define como uma das ações importantes em visitas a museus. Ou, em outras palavras, por meio do outro, o sujeito se apropria de instrumentos para a transformação da realidade objetal em realidade mental, construindo sua própria forma de interpretar o mundo, podendo, cada vez mais, assumir o controle de suas ações e, consequentemente, produzir novos artefatos que promovam formas específicas de desenvolvimento intrapessoal e relações interpessoais.

Nesta perspectiva, as mediações social e semiótica em curso ao considerar as ações de leitura de legenda de Tatiana e Sofia poderiam ser sintetizadas na Figura 15. 

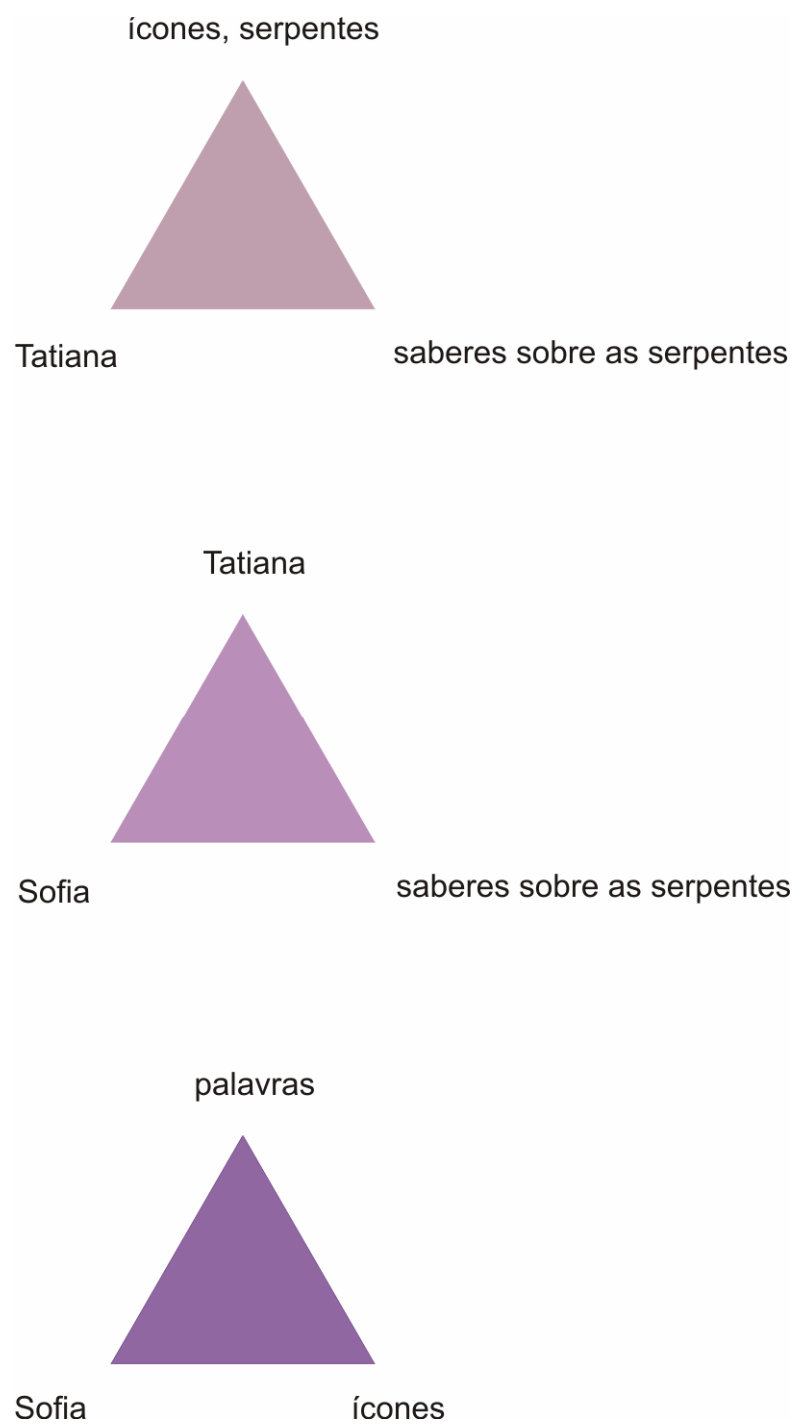

Figura 15 - Sistemas de mediação observados na iniciação de Sofia à leitura de ícones.

\subsubsection{A formação conceitual e a ascensão do abstrato ao concreto}

Sofia e Tatiana, bem como todos os seres humanos, nasceram em um mundo em que o conhecimento está disponível como o procedimento central, padrão, para lidar com pessoas e coisas. Mas, como ressalta Hedegaard (1996), é importante diferenciar o conhecimento que existe independentemente de Sofia e a aquisição e o desenvolvimento desse conhecimento por ela. 
Como já mencionado anteriormente, esses procedimentos-padrão, esses conhecimentos, são localizados histórica e culturalmente e resultam de processos desenvolvidos socialmente para a resolução de problemas. Dessa forma, assume-se que as práticas sociais antecedem os conhecimentos sociais, levando à rejeição da suposição de que estes existam independentemente daquelas: "as habilidades socialmente desenvolvidas, portanto, são a base para os conhecimentos socialmente desenvolvidos" (HEDEGAARD, 1996, 345).

Vale então trazer novamente as ideias de Davidov, para quem esse conhecimento societário pode ser separado em duas formas distintas: o conhecimento empírico e o conhecimento teórico. Enquanto o primeiro lida com diferenças e semelhanças de um fenômeno individual e surge por meio da observação e comparação de objetos e eventos, o segundo lida com um sistema integrado de fenômenos e emerge por meio do desenvolvimento de métodos para solução de problemas. Para o autor, no processo de apropriação desses conhecimentos, os sujeitos podem adotar posturas distintas de compreensão do fenômeno, podem assumir mecanismos diferentes para compreender a realidade. E, dependendo do caminho percorrido, diferentes serão também os mecanismos pelos quais resolverão problemas posteriores.

Entretanto, não se pode falar em uma "sensibilidade em geral" ao se determinar a relação entre a percepção do real e os diferentes tipos de pensamento. O fato de um objeto ser captado sensorialmente não define a priori o tipo de sua expressão racional. Como coloca Davídov (1988, p. 137-8, tradução nossa):

se este objeto é examinado em si mesmo, fora de certo sistema e da conexão com outros objetos, pode se converter em conteúdo do pensamento empírico. Se o mesmo objeto é analisado dentro de certa concretude e somente assim podem ser reveladas suas verdadeiras particularidades, se converterá em conteúdo de pensamento teórico.

É possível perceber essa escolha diferenciada em relação às formas de apropriação dos objetos quando são analisados dois episódios extraídos das conversas das famílias G6 e G7 em visita ao Museu Biológico. Nos dois grupos, houve a observação direta dos objetos museais, no caso, biodioramas de serpentes brasileiras. O episódio abaixo (E2) ilustra como a família G7, a partir da observação de dois dioramas (cascavel e periquitamboia), procura dar significado ao que vê e lê, em uma construção coletiva, lançando mão de conhecimentos do grupo: 
1. Ana Luiza: Ô, Di, quando você encontrar a cobra dali, você vai levar um susto.

2. Anderson: Eu tirei uma dessa aqui, ó. Dá pra ver bem o chocalho dela aqui, ó.

3. Diane: Hã, hã.

4. A: E olha, ela tá bem...

5. Neusa: Ali é uma só ou são duas?

6. A: Não, tem mais que uma. Não é possível...

7. N: Eu acho que é uma só, hein, porque a cabeça dela tá aqui e o guizo ali, ó.

8. D: Mas ó o tamanho dela lá pra dentro...

9. A: Mas é legal que cê vê a diferença dela, assim pertinho, e a diferença da naja em posição de ataque. Ela abre, né?

10. N: Ahã, ela só levanta.

11. A: É.

12. N: A que abre, a que arma, é a naja.

13. D: Ela, ela se enrola, aí a cabecinha dela fica assim...

14. A: O chocalho fica no meio...

15. D: ...e o chocalho no meio.

16. N: Hum... misericórdia...

17. A: Ó aquela ali, amor. Aquela é de brinquedo. Aquela eu tenho certeza que é de brinquedo.

18. N: Foi... de brinquedo... (duvidando).

19. A: Foi...

20. D: Olha amor. Parece... é periquito. Periquitamboia.

21. A: Periquitamboia!... (risos).

22. D: Mistura de periquito com jiboia (risos). Por isso que ela fica na árvore.

23. N: Hum... Ela muda de cor.

24. D: Cobra-papagaio, tá vendo como é uma mistura de ave com cobra?

25. N: Possui coloração verde quando adulta e quando jov... indivíduo jovem são geralmente cor de laranja (lendo).

26. D: La-ran-ja! Que legal!

27. N: Ó.. pequenininha...

28. D: É. Essa deve ser peçonhenta, né? Não. Não. Não peçonhenta.

29. N: Não peçonhenta.

30. D: Eu achei que era porque ela se alimenta de... de rato e morcego... Hábitos noturnos...

No trecho descrito acima, observa-se uma aproximação da família com os saberes científicos expostos no museu, em que Diane teve consciência de uma contradição entre seu conceito empírico (as serpentes que se alimentam de ratos e morcegos são peçonhentas) e a voz institucional exposta na legenda (a periquitamboia alimenta-se de roedores e morcegos e 
não é peçonhenta). Durante toda a visita, Diane envolveu a família no intuito de compreender os elementos para uma serpente ser considerada peçonhenta. O problema inicial, surgido a partir de uma necessidade de Diana em compreender quais serpentes são perigosas para a vida humana, colocou toda a família em atividade de aprendizagem. Assim, os outros membros do grupo também assumiram a tarefa de identificar serpentes peçonhentas.

A família G6 apresentou problema semelhante, buscando formar um conceito de serpente peçonhenta compreensível a todos do grupo. Diferentemente da família G7, em que foi possível estabelecer claramente o início do episódio com o conflito de Diane, nesse grupo, considerou-se a fase inicial do episódio (E3) um conjunto descontínuo de falas em que um dos membros expôs seu conceito de serpente peçonhenta. Em algumas passagens, Maria Lenise apresentou um conceito empírico de serpente peçonhenta bastante comum: as de maior tamanho são venenosas. Em vários momentos, surpreendia-se com a presença de serpentes peçonhentas pequenas, demonstrando que seu conceito de serpente peçonhenta não incluía as de menor tamanho.

Em continuidade a essas falas não sequenciais, mas coesas, observou-se o seguinte trecho:

Os três membros da família G6 posicionaram-se frente ao biodiorama da cascavel.

1. Maria Lenise: É a cascavel.

2. Rita: É cobra, não é víbora.

$[\ldots]$

3. R: Tô achando que a maioria é cobra, não é venenosa...

4. ML: Cobra é não peçonhenta?

5. R: Cobra é não peçonhenta e víbora é peçonhenta. Em espanhol, quando se fala "culebra" é a cobra e "víbora" é a peçonhenta.

$[\ldots]$

6. ML: Mas é peçonhenta, ó (apontando para a legenda da cobra coral)!

7. R: Ah, elas mordem! ... Ó, Gui, e essa envenena e morre logo rapidinho. E olha o tamanhico dela.

8. G: Falsa coral. E essa é a coral verdadeira. Ó gente, olha mãe, falsa coral, mãe.

9. ML: E tu viste uma coral dessa na Ró, na garagem da Ró?

10. G: Não, não vi.

11. R: É mesmo?

12. ML: Quem diz que uma coral dessa pode matar?

13. R: É linda...

14. ML: É mesmo. Pra mim é a cobra mais linda... 
Na suposição de Rita (intervenção 3), há um questionamento da proposta de Maria Lenise de associar o tamanho da serpente ao seu grau de periculosidade, com a apresentação de uma nova ideia: a partir dos termos espanhóis "culebra" e "víbora", traça o seu paralelo em português com "cobra" e "víbora"97. Maria Lenise dá atenção a essa nova proposta e procura relacioná-la com aquilo que observa na exposição. Ao encontrar conflitos no uso dessa novo modelo, expressa sua negação à Rita (6), que passa então a buscar uma alternativa para o fato de uma cobra (a cobra coral) ser peçonhenta. Ela encontra a resposta em um traço externo, que as uniria às serpentes peçonhentas: as cobras corais "mordem" (7). Dessa forma, os visitantes da família G6 procuraram compreender o conceito de serpente peçonhenta a partir de exemplos expostos, identificando aquelas características que os ajudariam a formar esse conceito: tamanho da cobra, denominação, comportamento de mordida. Entretanto, as generalizações realizadas foram bastante particulares e não deram conta de explicar os objetos e eventos observados, dentro mesmo do Museu.

Nesse episódio, pode-se supor que a família empregou o pensamento empírico para a resolução do problema. A partir dos objetos museais, levantaram traços externos e os compararam às representações que possuíam sobre serpentes peçonhentas (serpente grande, denominada víbora e que morde), apoiados em suas observações sensorialmente concretas. Além disso, não elaboraram um plano geral de ação que os permitissem empregar esse conceito em outros problemas que lhes surgissem em condições diferentes. Apesar de serem encontradas evidências de aprendizagem, como conversas perceptivas (de identificação e nomeação) e conectivas (com experiências passadas), conforme as categorias de Allen (2002), não é possível assumir que esses visitantes estavam em atividade de aprendizagem do conceito, no sentido aqui trabalhado, pois para tal, seriam necessárias não só a transformação do sujeito, sua autotransformação, mas a re-produção, por ele, do discurso exposto no Museu.

A família G7 resolveu o problema por outro caminho:

1. Neusa: (lendo painel) Ó, ó... Escuta: algumas serpentes não peçonhentas têm fossetas labiais que exercem a mesma função das fossetas loreais. O que que é isso?

2. Anderson: Ana Luisa, o que que é uma fosseta loreal?

3. N: O que é a fosseta loreal?

\footnotetext{
${ }^{97}$ No Brasil, também é encontrada, no senso comum, a diferenciação dos termos "cobra" e "serpente", sendo o primeiro relacionado aos animais não-peçonhentos. No campo acadêmico, os dois termos são genéricos, referindo-se aos animais da Subordem Serpentes. A predileção, entre os herpetólogos, pertence ao termo "serpentes", assim como os geólogos preferem "rocha" à "pedra" e os zoólogos, "animal” à "bicho".
} 
4. A: Loreal, eu sei que é aquele, aquele.... de passar no cabelo... loreal!

5. Diane: ....aquele negócio de passar no cabelo (ao mesmo tempo que Anderson).

6. A, D e N: (risos)

7. Ana Luiza: Que que é isso?

8. N: Isso é uma curtura que eu vô te contar, hein! O gente curta da....

9. D: É mentira? É mentira? Fala que é mentira...

10. AL: Ô mãe?! Vem ver aqui essa! A suaçuboia.

11. N: Então, depois eu vou perguntar lá.

12. AL: Mãe, vem aqui ver a suaçuboia. Mãe, vem aqui ver a suaçuboia. Mãe, vem aqui ver a suaçuboia!

13. D: Então, ó, mas ele aqui tá mostrando: fossetas labiais.

14. N: Então... fossetas lab...

15. D: Ó, fosseta loreal é esse focinho aqui. Aqui mais na frente, mais em cima (apontando para imagem no painel).

16. N: Não tem nada a ver, Diane.

17. AL: (ao mesmo tempo, sozinha) Cabeça redonda! Cabeça redonda! Cabeça redonda!

18. D: Vocês não entende nada.

19. A: Labial, amor.

20. N: Labial é lábio...

21. A: Com certeza.

22. N: E loreal?

23. D: É no cabelo... Tô falando!

24. A: É que isso aqui são fossetas... Percebeu... que aqui tem no lábio...

25. D: Fosseta é de, acho que é de...

26. A: De fosso.

27. N: De, de... fósseis...

28. D: De fósseis, você ganhou, de fósséis!... Você ganhou! (risos)

29. A: Fóssil nasal! A curtura! (risos)

30. N: Ó, ó, isso é um fóssil nasal... (risos)

31. D: Fóssil... fóssil, você ganhou...

32. AL: Qual que é? Qual que é? Aqui, essa é uma jiboia.

33. N: (para $A L$ ) Escuta, escuta! Isso aqui não é pra ficar berrando aqui dentro e fazendo bagunça, não, hein?

De forma coletiva e compenetrada (a criança Ana Luiza chamava por seus parentes recorrentemente, mas não era atendida), os três adultos buscaram uma explicação para o conceito de fosseta loreal (que, como haviam percebido, relaciona-se com as serpentes peçonhentas) e consideraram a importância de procurar elementos do discurso institucional 
para outras definições (11). Como afirmam Ellenbogen, Luke e Dierking (2004), os estudos sobre aprendizagem em museus sugerem que as famílias conversam sobre aquilo que elas sabem a partir experiências prévias, discutem o que veem, leem e escutam, geralmente baseadas nas suas memórias e experiências, compartilhando um conjunto de valores, vocabulário, compreensões e pressupostos.

Os adultos desse grupo, no trecho acima, delinearam o problema (1 a 3), fazendo um questionamento inicial: a dieta da serpente não se constitui como elemento explanatório de sua periculosidade, sendo necessário encontrar uma outro elemento para a resolução desse problema. As fossetas loreais apresentam-se aos visitantes da família G7 como uma possibilidade a ser investigada. Na legenda lida, o texto informava que serpentes nãopeçonhentas apresentavam fossetas labiais e as peçonhentas, fossetas loreais. Buscaram, a partir de uma abordagem etimológica, uma aproximação ao termo loreal que os fornecesse um significado instrumental ao entendimento da relação fosseta loreal/animal peçonhento (19 a 29).

É possível identificar essas ações como as primeiras descritas por Engeström (1999b) em seu ciclo de aprendizagem expansiva. $\mathrm{O}$ autor ressalta que esse ciclo está baseado nas ideais de atividade de Leontiev e de ascensão do abstrato ao concreto, de Davidov. Para ele, essa ascensão corresponde a um método de capturar a essência de um objeto ao mapear e reproduzir a lógica de seu desenvolvimento, em suas contradições e resoluções internas, em que um novo conceito é produzido na forma de uma relação explanatória simples, abstrata (célula germinal). Essa abstração inicial é enriquecida paulatinamente, transformando-se em um sistema concreto de múltiplas manifestações. Em um ciclo de atividade expansiva, essa célula germinal é transformada em um novo objeto complexo, em uma nova prática e novos conceitos teóricos.

Baseado ainda em Davidov, ressalta que, nessa abordagem, o abstrato refere-se ao parcial, àquilo que é separado do todo concreto. No pensamento empírico, originado da comparação e da classificação, a abstração captura as propriedades arbitrárias e formalmente interconectadas. No pensamento teórico, baseado na ascensão do abstrato ao concreto, a abstração captura "o menor e o mais simples, a unidade geneticamente primária de todo o sistema funcionalmente interconectado" (ENGESTRÖM, 1999b, p. 383).

Esse autor define que, no processo de ascensão do abstrato ao concreto, são realizadas determinadas ações, que, juntas formam o ciclo aprendizagem expansiva: 
-Questionamento: o primeiro passo é o de crítica ou rejeição a alguns aspectos da prática vigente.

-Análise da situação: envolve transformações mentais, discursivas ou práticas da situação, buscando encontrar mecanismos causais e explanatórios e envolvendo questões do tipo “por quê?” e princípios explanatórios. Na análise genético-histórica, busca-se compreender a situação por meio de sua origem e evolução, enquanto na empírico-atual, por meio da construção de um quadro de suas relações sistêmicas.

-Modelagem: a nova relação explanatória passa a ser modelada em algum meio observável e transmissível. O modelo construído contém a explicação da resolução da situação problemática.

-Exame do modelo: o modelo é então testado, a fim de se observar suas limitações e potenciais.

-Implementação do modelo: nessa quinta ação, o modelo é concretizado por meio de aplicações práticas, enriquecimentos e extensões conceituais.

-Reflexão: ocorre a reflexão sobre o processo transcorrido

-Consolidação: os resultados são consolidados em uma nova prática.

Um ciclo expansivo inteiro, em sua forma típica e ideal, pode ser representado como na Figura 16.

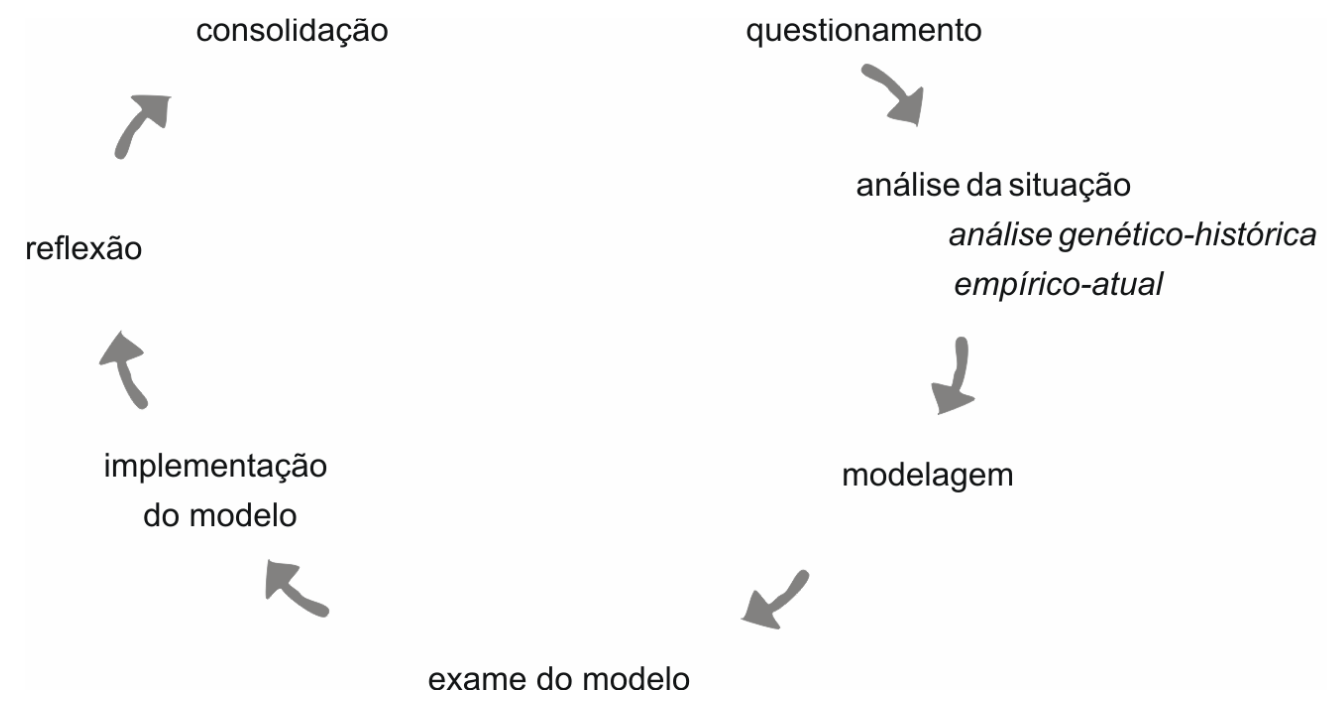

Figura 16 - Ciclo de aprendizagem expansiva segundo Engeström (1999b). 
Nesta perspectiva, é possível compreender o engajamento inicial da família em identificar uma serpente peçonhenta como representativo das primeiras fases do ciclo de aprendizagem expansiva de Engeström. A partir de um questionamento inicial em relação à prática anterior de identificar uma serpente peçonhenta por sua dieta, passaram a realizar transformações discursivas a fim de identificar uma nova prática para identificação desses animais. Encontraram o conceito de fosseta loreal como uma possibilidade a ser examinada.

Ao localizar um representante do Museu, um monitor, Anderson desviou sua fala, até então dirigida à família, incluindo-o na conversa. Em seguida, perguntou sobre o conceito de fosseta loreal:

Anderson traz o monitor de volta ao painel com o termo fosseta loreal. Neusa segue os dois. Diane também os segue e Ana Luiza fica sozinha, parada no corredor central da exposição. Quando Ana percebe a filmadora, junta-se ao grupo por alguns segundos.

1. A: (para monitor) Que que quer dizer isso aqui? Fossetas labiais...

2. N: ...e fosseta loreal.

3. Monitor: Já ouviu falar em fosseta loreal? As serpentes brasileiras são identificadas como peçonhentas quando elas tem um órgão, um orifício chamado fosseta loreal entre os olhos e a narina.

4. D: Tá vendo! (referindo-se às suas falas apresentadas no trecho anterior que não foram consideradas pelo grupo).

5. M: (continuando) O olho tá aqui, o nariz tá aqui e aqui tem esse buraquinho. Que que é esse buraquinho? Que que é a fosseta loreal? É o buraquinho que vai identificar a presa ou quem tiver próximo pelo calor. Através do calor é um órgão termoreceptor. Por exemplo, eu sou uma cobra, eu vou saber que você é você pelo seu calor que você.. expele.

6. A: E isso aqui é o que capta esse calor?

7. M: Exatamente. Algumas cobras, todas as peçonhentas do Brasil tem isso, com exceção da coral, que não tem.

8. D: Ahã, ahã.

9. M: No caso da coral, ela tem uma fosseta labial. Tá vendo esse pedacinho daqui, da periquitamboia?

10. A: Ahã..

11. M: Isso é uma fosseta lo... labial. Funciona como se fosse uma loreal, só que nos lábios.

12. A: Ah, tá...

13. M: É uma diferença entre uma peçonhenta e uma não peçonhenta no caso.

14. A: Então essa fosseta seria essa essa espécie de radar de captar.... 
15. M: Isso... Receptor!

16. A: Receptor...

17. D: Aí, ó, eu expliquei tudo isso pra vocês... Aí, tá vendo, ó (risos).

18. N: Você não, você não explicou nada disso.

19. A: Então, tá! Então toda cobra, mas, hã... toda cobra venenos.... isso não é...

20. M: Se tiver esse buraquinho... é peçonhenta, é venenosa.

21. A: Se tiver isso aqui é venenosa?

22. M: É, toda cobra.

23. A: Com exceção da coral, né?

24. M: Com exceção da coral.

25. M: No Brasil.

26. A: No Brasil.

27. N: Então, mas é igual o que eu tava falando. Cê acha que eu vou ver uma cobra, eu vou ficar olhando ali pra ver se a cabeça dela é triangular, se ela tem buraco ou se ela não tem. Imagina!

28. A: (ao mesmo tempo, para $A L)$ Eee, levanta aí...

29. A: Essa era uma outra pergunta que eu tinha. Essa, essa... é mito ou é real, esse negócio da cabeça triangular?

30. M: No Brasil a gente não usa isso. Não é viável isso também. Por exemplo, essa aqui é a periquitamboia...

31. D: Que é essa daqui, não, cadê? A verde...

32. M: ... tem a cabeça triangular, concorda?

33. A: Mas ela não é venenosa...

34. M: O olho em forma, em formato de fenda... e ela não é venenosa. Então no Brasil a gente não utiliza essa... esse sistema que a gente é... esse padrão, a gente padroniza isso... 35. N: Hum, hum...

36. D: E essa aqui, essa cobra aqui que tá em fase de adaptação, ela é venenosa?

37. M: Não, também não. Dá pra você observar, ó: tem o olho e tem um buraco bem grande que é o nariz dela, concorda?

38. D: Ahã.

39. A: Mas ela não tem...

40. M: Ela não tem a fosseta loreal. Cê pode dizer que ela não é coral, se não é coral, se não tiver a fosseta loreal, sinal que ela não é peçonhenta. Certo?

41. D: Ah, legal. Brigada.

42. M: De nada.

43. A: Brigadão, hein. Qual é seu nome mesmo?

44. M: Y. Qualquer coisa a gente vai tá por aí.

45. A: Y! Tá bom. Obrigado.

46. D: Brigada. 
No trecho acima, percebe-se que a intervenção do monitor foi importante para que os visitantes avançassem no ciclo de aprendizagem. Com as explanações oferecidas, os visitantes reorganizaram sua compreensão do termo fosseta loreal (14 e 21) e procuraram relacioná-lo sistemicamente a outros eventos, aproximando-se de formá-lo como um conceito. Nesse caso, Anderson utilizou outros conceitos (coral, radar, cabeça triangular) para situar o novo em uma rede relacional. Um modelo diferente surge então, em forma de signo, para identificar uma espécie peçonhenta: a presença de fosseta loreal.

Com a ajuda no monitor, o grupo avança além das ações iniciais do ciclo e examinam o novo modelo criado (36 a 40), verificando sua aplicabilidade. Tem-se aqui mais um exemplo de situação de ensino/aprendizagem desenvolvida dentro da Zona de Desenvolvimento Imediato da família. Em um momento posterior, os visitantes fazem sozinhos aquilo que anteriormente fizeram com a ajuda do monitor:

Em frente a outro biodiorama, o grupo retoma o conceito de fosseta loreal a partir da legenda.

1. Anderson: Olha Neusa, entre uma dessas daqui é mais agressiva, possui fosseta loreal! (lendo) Abre parênteses, é um orifício entre o olho e a narina que é um aparelho térmico. Viu? É. É, forma imagem. (?) Fantástico. Olha essa, ó. Essa já é venenosa e pequena. Tá vendo?

(?) Você acha que dá pra ver a fosseta loreal dela? Aqui, ó (apontando para a fosseta loreal). Essa também é peçonhenta.

Poderia-se supor que, com as ações coletivas e a ajuda do monitor, os visitantes completaram um microciclo de atividade de aprendizagem expansiva, conseguindo elaborar um modelo mental, uma nova forma de identificar serpentes, que resolveria outros problemas futuros relacionados à identificação de uma serpente peçonhenta (por exemplo, ao se depararem com uma delas durante uma caminhada ou ao assistirem um filme sobre a anaconda e observar a ausência de fosseta loreal). Nesse sentido, uma abstração inicial, a generalização do termo fosseta loreal, transformou-se em um conceito concreto, operado em uma nova prática. Ou seja, houve a transformação do objeto "fosseta loreal" em signo mediador "fosseta loreal", alterando assim sua prática de reconhecimento de serpentes peçonhentas.

Entretanto, vale lembrar que as ações descritas por Engeström (1999b, p. 384, grifo do autor, tradução nossa) constituem um processo de aprendizagem entendido como "a construção e a resolução de tensões e contradições sucessivamente envolvidas em um complexo sistema que inclui o objeto ou objetos, os artefatos mediadores e as perspectivas 
dos participantes", que se apresenta em uma espiral contínua, voltado principalmente para instituições ou coletividades, em períodos de dois ou três anos. O próprio autor faz uma ressalva para a mudança de escala, quando se olha para fases que duram "minutos, talvez uma hora ao invés de meses ou anos. Podem esses ciclos em miniatura serem considerados expansivos?” (ENGESTRÖM,1999b, p. 385, tradução nossa).

Segundo o idealizador do modelo, a resposta é positiva e negativa: eles podem ser considerados potencialmente expansivos. Os ciclos maiores são compostos de ciclos em pequena escala, como visto anteriormente, mas o surgimento de microciclos não garantem que um ciclo expansivo evolua. Nesse sentido, entender as ações desenvolvidas pelos visitantes da família G7 como constituintes de um microciclo de atividade de aprendizagem expansiva necessitaria olhar para suas ações posteriores à visita ao museu, bem como a influência dos resultados de sua visita sobre a prática educativa da instituição, o que fugiu do alcance desta investigação.

Além disso, vale ressaltar que as ações de aprendizagem para a ascensão do abstrato ao concreto propostas por Engeström assemelham-se, estruturalmente, àquelas desenvolvidas por Davidov.

Esse autor (DAVYDOV, 1988b, 1999a) propõe seis ações principais em uma atividade de aprendizagem: 1) transformação das condições da tarefa, a fim de encontrar as características básicas desse tipo de tarefa e evidenciar suas relações gerais; 2) modelagem dessas relações, por meio de objetos, signos ou gráficos; 3) transformação das relações do modelo, para se estudar cuidadosamente as propriedades da relação geral já encontrada; 4) construção de outras tarefas a partir do modelo; 5) Controle das ações de aprendizagem pelo estudante, possibilitando a correção da execução dessas ações; 6) Avaliação da esfera de aplicação do modelo, a fim de se determinar se o modo geral de resolução do problema é apropriado e extensível a essa e a outras tarefas.

Mas, ao comparar as ações de aprendizagem de seu ciclo expansivo com as ações da atividade de aprendizagem do pesquisador russo, Engeström ressalta algumas diferenças. A ação de questionamento e crítica à situação vigente não é encontrada na sequência de Davidov, o que seria explicado, segundo o autor, pelo fato da teoria davidoviana estar orientada para os processos de aprendizagem que ocorrem na sala de aula, onde os conteúdos curriculares são determinados, geralmente, pelos adultos envolvidos. Isso explicaria ainda a inclusão das ações de implementação de um novo modelo e de consolidação de nova prática, 
substituindo as ações, de Davidov, de construção de um sistema de tarefas particulares e avaliação (Tabela 7).

Tabela 7 - Ações de aprendizagem segundo Davydov (1988b) e Engeström (1999b).

\begin{tabular}{lll}
\hline & \multicolumn{1}{c}{ Davydov } & \multicolumn{1}{c}{ Engeström } \\
\hline 1 & & Questionamento \\
2 & Transformação da tarefa & Análise \\
3 & Modelagem & Modelagem \\
4 & Transformação do modelo & Exame do modelo \\
5 & Construção de novas tarefas & Implementação do modelo \\
6 & Controle & Reflexão \\
7 & Avaliação & Consolidação da nova prática \\
\hline
\end{tabular}

Entretanto, as diferenças entre as ações de Davidov e de Engeström não são somente estruturais. Elas diferem nas condições em que se originaram e ainda em seu conteúdo: enquanto as primeiras foram elaboradas a partir de pesquisas desenvolvidas no ambiente escolar, as outras foram adaptadas considerando-se contextos variados, mas principalmente, aqueles onde se desenvolve a atividade prática do trabalho profissional, objeto de estudo principal do pesquisador finlandês. Nos estudos de Davidov, foram priorizadas as investigações sobre a aprendizagem de conceitos científicos, buscando-se sistematizar um conjunto de ações que promovessem a ascensão do abstrato ao concreto. Já nas pesquisas de Engeström, a mesma lógica foi empregada, mas a ênfase incide sobre a aprendizagem de novas práticas que solucionem problemas e contradições de situações coletivas cotidianas.

Se, por um lado, a primeira abordagem de análise é interessante aos museus de ciências, pois os conceitos científicos são inerentes a esses ambientes, por outro, uma abordagem constituída fora da escola e voltada para aprendizagem de objetos variados também deve ser considerada. No exemplo citado acima, ao entender o objeto da aprendizagem como 'novas práticas de identificação de serpentes peçonhentas', é possível assumir que houve uma ascensão do abstrato ao concreto, que os visitantes, lançando mão de conceitos, da monitoria, de conhecimentos do grupo, questionaram sua prática anterior e puderam construir um novo modo de identificar serpentes, enquanto prática do grupo. 
Entretanto, ao se considerar a ascensão do abstrato ao concreto do 'conceito de serpentes peçonhentas', essa conclusão não é tão imediata. É possível argumentar que os visitantes da família G7, ao localizarem a fosseta loreal como uma característica de um animal peçonhento, levantaram mais um traço externo do objeto serpente, que se distingue de "cabeça triangular", "tamanho do corpo" ou "dieta", simplesmente porque este, "fosseta loreal", é aceito pelos herpetólogos ${ }^{98}$.

Ao se imaginar um contínuo entre as duas abordagens, entre o foco na aprendizagem de práticas e o foco na aprendizagem conceitual (que tem como produto uma nova prática), é possível que os museus fiquem numa posição intermediária, sendo necessária a identificação de quais são as ações próprias a esses contextos que promovem a concretização, pelo visitante, do discurso exposto. Para isso, faltam pesquisas em diferentes tipologias de museus, focadas em um ponto chave desses ambientes, a interação com o objeto museal, e em escopo suficiente para que possa ser detectada a "essência", o princípio universal das ações de aprendizagem em museus, na perspectiva histórico-cultural da Teoria da Atividade, sistematizado em um conjunto de ações particulares a esses ambientes.

Mas, limitando-se às ferramentas disponíveis e considerando-se os ciclos de Engeström, é possível representar as relações interativas estabelecidas pelos visitantes das famílias G6 e G7 pelos esquemas a seguir:

98 O termo peçonhento foi introduzido no Brasil por Afrânio do Amaral (artigo publicado em meados do século $\mathrm{XX}$ ), em que procurou distinguir um animal peçonhento de um animal venenoso: peçonhento é aquele que possui veneno e consegue injetá-lo, enquanto venenoso é aquele que não tem um aparelho inoculador. Essa distinção é bastante arbitrária. A princípio, sugere um questionamento óbvio: inocular em quem? Uma cobraespada (Tomodon dorsatus), por exemplo, não consegue injetar seu veneno em seres humanos em uma picada (entretanto, possui uma dentição tal que se morder o dedo de uma pessoa por alguns minutos conseguirá inocular o veneno), mas o faz eficazmente se é considerada sua presa, uma lesma. Outro exemplo de contradição interna do conceito é o da cobra boiubu (Philodryas olfersii) que é considerada um animal não peçonhento (não tem fossetas loreais) mas pode causar acidentes graves em humanos, podendo levar à morte. Ou seja, não são somente os animais com fosseta loreal que são perigosos ao homem. Além disso, a visitante da família G6 (com seu conceito de "culebra" não venenosa e "víbora" venenosa) teria dificuldades com essa ideia de animal peçonhento, pois as víperas do velho mundo não possuem fosseta. 
legendas, conhecimentos do grupo

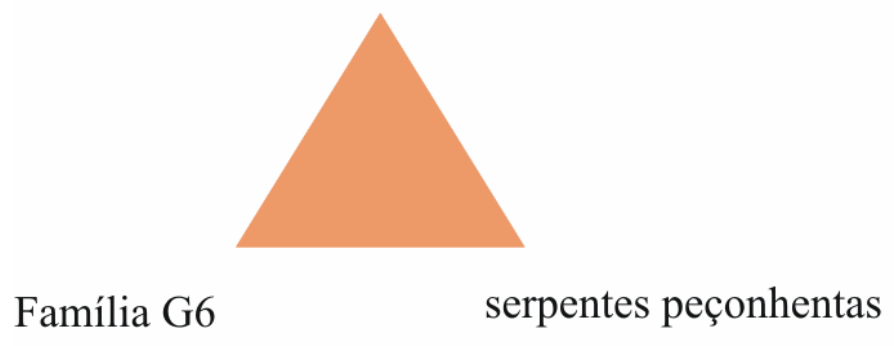

serpentes peçonhentas, conceito de fosseta

resultado: modelo de

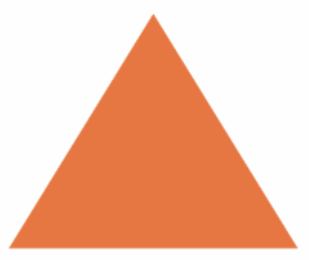
identificação de serpente peçonhenta e desenvolvimento de ação mental

Família G7

conceito de serpente peçonhenta

Figura 17 - Sistemas de interações apresentadas pelas famílias G6 e G7.

É importante observar que essas representações gráficas não ressaltam a natureza colaborativa das ações desenvolvidas nessa atividade. Os resultados da ação ficam restritos à situação dada, àquela relação entre sujeito e objeto. Mas, como visto, o movimento da aprendizagem apresentado pelos visitantes é mais amplo e exige outros elementos no diagrama apresentado. 
O conceito de aprendizagem situada, como proposto por Lave (1988) e de "participação periférica legitimada" (legitimate peripheral participation) (LAVE; WENGER, 1991) pode ser útil para essa tarefa. Esse conceito, abordado anteriormente (Capítulo 1), ao ser utilizado para a compreensão do processo de aprendizagem, coloca ênfase no processo de participação em preferência ao de internalização. Segundo os autores, essa escolha foi feita pois a aceitação imediata do processo internalização oferece o risco de estabelecer uma dicotomia rígida entre exterior e interior, enquanto que uma teoria da prática social enfatizaria a "interdependência relacional de agente e mundo, atividade, significado, cognição, aprendizagem e conhecimento. [...] Numa teoria da prática, a cognição e a comunicação no e com o mundo social são situadas no desenvolvimento histórico da atividade ininterrupta" (LAVE; WENGER, 1996, p. 168). A aprendizagem é vista, pelos autores, como produção, transformação e mudança histórica das pessoas.

Embora alguns autores coloquem a abordagem da prática social participativa e os modelos de desenvolvimento baseados na internalização como duas visões de mundo bastante distintas (por exemplo, MATUSOV, 1998), pode-se observar que esta diferenciação reflete, muitas vezes, as diferentes concepções de internalização utilizadas.

$\mathrm{Na}$ concepção aqui utilizada, em que a internalizacao é vista como um processo articulatório entre dois planos mutuamente constituintes, o social e o individual, e não como um processo de transmissão do primeiro ao segundo, essas duas abordagens não são excludentes. Ao contrário, as ideias de Lave e Wenger somam-se às de Vigotski e fornecem um arcabouço teórico mais abrangente na interpretação do processo de aprendizagem em museus.

Elaborações conversacionais que indicam interações entre membros mais experientes e membros novatos de uma comunidade de prática podem ser encontradas recorrentemente ao longo das visitas dos grupos entrevistados. Um exemplo bastante comum refere-se a um trecho extraído das conversas da família G7:

1. Neusa: (dirigindo-se à Ana Luiza) Benzinho, é bom você olhar nos bichos e você ler pra você entender o que que ela é, o que que ela não é. Não é chegar e dar uma olhada nele e sair correndo. Leia filha, é interessante você saber disto. Você viu essa cobra que linda as cores dela, ali? A jiboia...

Nesse sentido, ao chamar sua filha Ana Luiza para ler as legendas e observar as serpentes, Neusa pode ser considerada um membro mais experiente da comunidade de 
visitantes de museus, que ensina aos novatos os repertórios de sua prática. A mãe torna-se sujeito também de uma atividade de ensino. Na visão de Lave e Wenger (1991), a aprendizagem de Ana Luiza sobre visitas a museus teria se iniciado quando a criança começou a freqüentar esses espaços e continuará ao longo da sua vida, sendo que em algum momento passará a ensinar aos novos membros da comunidade os elementos da prática de visitar museus.

Prosseguindo, Ana Luiza e sua mãe participariam ainda de outras comunidades. Nos ambiente museais, há uma diversidade delas: além da comunidade de visitantes, elas fariam parte de comunidades de biólogos, de professores, de pesquisadores, de administradores e de educadores do museu, em algumas, de forma mais central, e, em outras, mais periférica. Nessa ótica, "a aprendizagem como participação periférica legítima não é simplesmente uma condição para tornar-se membro, mas é em si mesma uma evolução do tornar-se membro" (LAVE; WENGER, 1996, p. 170), bem como a reprodução e transformação da própria comunidade de prática.

Os conceitos de comunidade de prática e de aprendizagem periférica lançam luz sobre um elemento importante da atividade: a divisão de trabalho no grupo, já desenvolvida por Leontiev nos sistemas de atividade coletiva. Nas comunidades, há a resolução coletiva de um problema em comum, geralmente imersa em conflitos e tensões, mas, de alguma forma, produtiva. Assim, a "divisão de trabalho" dessas comunidades é intensa, frente ao número de pessoas envolvidas numa visita ao museu. Há o trabalho de uma série de profissionais, como museógrafos, educadores, pesquisadores, técnicos administrativos, curadores, taxidermistas, artistas plásticos, assessores de imprensa, que vão além dos visitantes com suas tomadas de decisão (tempo, circuito, reflexão, forma de interação).

Essa atividade de ensino/aprendizagem, com o visitante como sujeito, está imersa em uma série de "regras", que vão desde as mais evidentes no espaço museal (não bata no vidro, não corra, fale baixo) até as mais difíceis de serem percebidas, como a determinação do espaço livre para circulação, a seleção de temas expostos, a limitação da entrada pelo preço do ingresso, entre outras.

Assim, a representação diagramática anterior poderia ser ampliada: 


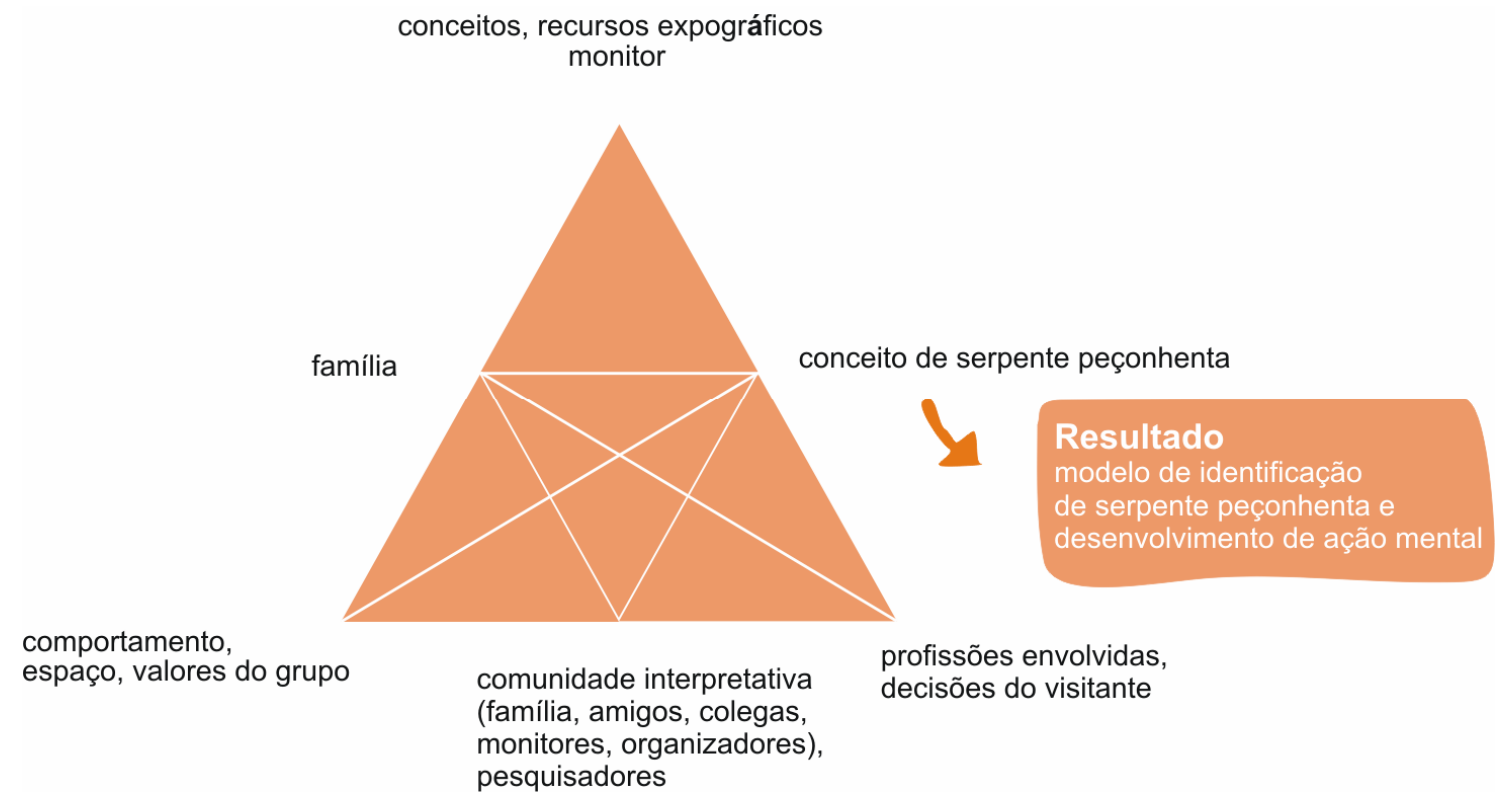

Figura 18- Modelo de atividade de ensino/aprendizagem de visitantes do Museu Biológico.

\subsection{A ATIVIDADE DE ENSINO/APRENDIZAGEM PELO OLHAR DO MONITOR}

Ao se deslocar a análise do ponto de vista do visitante para o do monitor, outros elementos emergem, sugerindo novas reflexões.

Os quatro monitores do Museu Biológico entrevistados (Rafaela, Antônia, Cláudio e Micael $^{99}$ ) são todos biólogos, graduandos ou graduados, na faixa dos 21 aos 37 anos ${ }^{100}$. Todos cursaram também a licenciatura em Ciências Biológicas, fato que consideram pouco importante para a sua prática atual de monitoria em museus ("A minha licenciatura não ajudou em nada na minha prática no museu" - Cláudio). Não são freqüentadores desses ambientes, sendo que dois deles, Cláudio e Micael, não se identificam com esses espaços: "sinceramente, eu não gosto muito de museu, não." (Micael). Somente um deles, Rafaela, ao concorrer a uma vaga para atuar no Museu, tinha interesse em "criar novas aulas, inventar coisas para fazer com o público.” Dois deles (Antônia e Cláudio) procuram um estágio no Museu pois gostariam de aprender a manusear e manter animais em cativeiro, mesmo sabendo que "teriam que atender os visitantes". O quarto monitor, Micael, também desejoso de lidar

\footnotetext{
${ }^{99}$ Nomes fictícios.

${ }^{100}$ O Museu contava com 12 monitores biólogos e três monitoras com mais de 65 anos, participantes de um programa de monitoria de Terceira Idade.
} 
diretamente com os animais do Museu, não sabia que a vaga a que estava concorrendo tinha como atribuição "falar com as pessoas", pois foi "na entrevista que me falaram que eu tinha que atender o público". Ao iniciar sua atividade de monitoria, "não fazia ideia do que [...] tinha que fazer".

Como já visto, o sentido que o indivíduo dá para sua atividade é o que constitui a própria atividade. Nesse caso, os monitores poderiam estar em atividade de ensino caso seu motivo principal fosse ensinar. É possível observar essas diferenças quando as entrevistas de dois monitores, Micael e Antônia, são analisadas em maior detalhe. Como observado nas falas de Micael, a mediação entre instituição e público não se constituía como uma atividade, mas como uma ação imersa em sua atividade de bioterismo animal. Já Antônia, que inicialmente pretendia aprender técnicas de manuseio de animais e de manutenção de serpentes em cativeiro, modificou sua atividade ao longo dos dois anos de vínculo com a instituição. Nesse período, com a formação de um núcleo de educação em ciências no Museu Biológico, Antônia, gradativamente, priorizou suas ações junto ao público em preferência ao bioterismo. Para Antônia, aquilo que inicialmente era apenas um motivo compreendido, passou a ser motivo eficaz em sua nova atividade. Nessa perspectiva, a monitora somente atribuiu sentido aos diferentes elementos da atividade ao estar em atividade. Estando em atividade de ensino, as ações passaram a se constituir como uma estratégia que respondia à sua nova necessidade de organização do ensino.

Entretanto, ao conceber a atividade de monitoria como uma atividade de ensino, assume-se que ela inclui objetivos, além de conteúdos, tanto científicos quanto pedagógicos, e, principalmente, uma concepção do que seja o processo de ensino/aprendizagem em museus. Esse caráter intencional da atividade de ensino acaba por exigir do monitor um novo significado para o que é ensinar e aprender em museus.

Enquanto Micael, após três anos de monitoria, considerava essa ação como temporária e como uma fonte de renda (até conseguir outro emprego), Antônia, posicionava-se diferentemente. Apesar de ver sua atividade como temporária, pois não queria "chegar nos 40 fazendo a mesmo coisa", atribuía a ela um conteúdo importante: sua formação como educadora. Assim, procurou participar de seminários, palestras e cursos sobre Educação em Museus, além de participar de pesquisas na área.

Nesse sentido, é possível representar as atuais atividades de monitoria de Antônia e Micael na tabela a seguir: 
Tabela 8 - Atividades de monitoria de Antônia e Micael.

\begin{tabular}{lll}
\hline & \multicolumn{1}{c}{ Antônia } & \multicolumn{1}{c}{ Micael } \\
\hline necessidade & $\begin{array}{l}\text { Tornar-se educadora } \\
\text { Conhecimentos da educação } \\
\text { em museus }\end{array}$ & $\begin{array}{l}\text { Ter um emprego } \\
\text { Conhecimentos técnicos sobre } \\
\text { manutenção em cativeiro }\end{array}$ \\
motivo & Aprimorar sua prática educativa & $\begin{array}{l}\text { Aprender a cuidar de animais } \\
\text { em cativeiro } \\
\text { atividade }\end{array}$ \\
$\begin{array}{l}\text { Erocesso de } \\
\text { ensino/epreno }\end{array}$ \\
\hline
\end{tabular}

Vê-se, assim, que a atividade de monitoria do Museu Biológico inclui conteúdos diversificados, dependendo do sujeito envolvido. Os motivos que engendram a atividade dos monitores podem se relacionar ou não ao papel educativo dos museus. Entretanto, quando se considera a ideia de que "somos todos educadores"101, recorrente entre a equipe de biólogos do Museu, observam-se tensões internas.

Ao chegar na instituição, o monitor depara-se com um conflito imediato: deve assumir ações para as quais não se sente preparado (BIZERRA et al., 2008b). Não há um período de aproximação, um estágio anterior de prática em que os monitores possam iniciar uma reflexão sobre as principais questões da Educação em Museus. Entretanto, é chamado a ser, logo que chega à equipe, um "educador".

Percebe-se que a concepção de educação colocada a eles não resolvem os problemas surgidos em seu dia-a-dia: se "somos todos educadores", teríamos habilidades para, ao menos, tentar resolver os problemas que surgem na prática educativa.

Contudo, como coloca Moura (2003), é nessa situação de conflito, construída quando o monitor assume um novo espaço de sua formação, que o indivíduo pode se inserir num processo de profissionalização ${ }^{102}$. É no desenvolvimento de suas ações, a partir de seu contato

\footnotetext{
${ }^{101}$ Essa afirmação é expressa em palestras e aulas oferecidas pelos coordenadores do Museu Biológico (informação verbal).

${ }^{102}$ Não há uma "profissão" monitor no Instituto Butantan (assim como em outros museus). O Museu Biológico não contrata os monitores. O vínculo é estabelecido por meio da Fundação Butantan que criou uma
} 
com o outro (visitantes, bioteristas, pesquisadores e, principalmente, outros monitores) que aprende o que é ser monitor (MARANDINO, 2008). As dificuldades encontradas, observada, por exemplo, na fala de uma monitora ("a gente precisa de um recreacionista pra falar com as crianças") e o confronto com situações inesperadas exigem uma nova prática educativa. Nesses momentos, ocorre

um processo de negociação dos significados que eles [professores em formação] atribuem a si e à situação como um todo. Assim, o sentido para a atividade de ensino é criado, descoberto e apropriado na relação com os parceiros portadores de níveis diferentes de experiência que lhes "emprestam" determinadas significações a suas ações em situações objetivas (CEDRO, 2008, p. 150).

A atribuição de sentido à sua atividade é possível quando os monitores conseguem compreendê-la como aquilo que vai satisfazer as suas necessidades. No caso de Micael, cujo motivo principal era aprender a manter animais em cativeiro, os motivos apenas compreensíveis de ensino não foram suficientemente eficazes para que se envolvesse na constituição de novas práticas educativas que permitissem a transformação de seus motivos iniciais.

O mesmo não ocorreu com Antônia. Ela, ao se envolver na implantação do núcleo de educação em ciências do Museu, deparou-se com novas exigências: a busca de conhecimentos que a ajudariam em suas práticas educativas. Nesse movimento, seus motivos iniciais puderam ser transformados em motivos eficazes para o desenvolvimento de sua atividade educativa.

Assim, a atividade de ensino/aprendizagem de um monitor, como a de Antônia, poderia ser representada conforme a Figura 19.

especificidade para esse cargo, inexistente até 2004. Uma discussão sobre a profissionalização desse setor foi tema de um encontro sul-americano no Rio de Janeiro, o "Workshop Sul-Americano de Mediação em Museus e Centros de Ciências", em setembro de 2008, em que foram levantadas as situações de legalização da contratação desses profissionais em diferentes instituições museais. Apesar de vários participantes, incluindo-se os monitores, concordassem que a atividade deveria ser regulamentada e que a profissionalização traria benefícios a diferentes comunidades, os caminhos para isso ainda eram incertos e desconhecidos. 


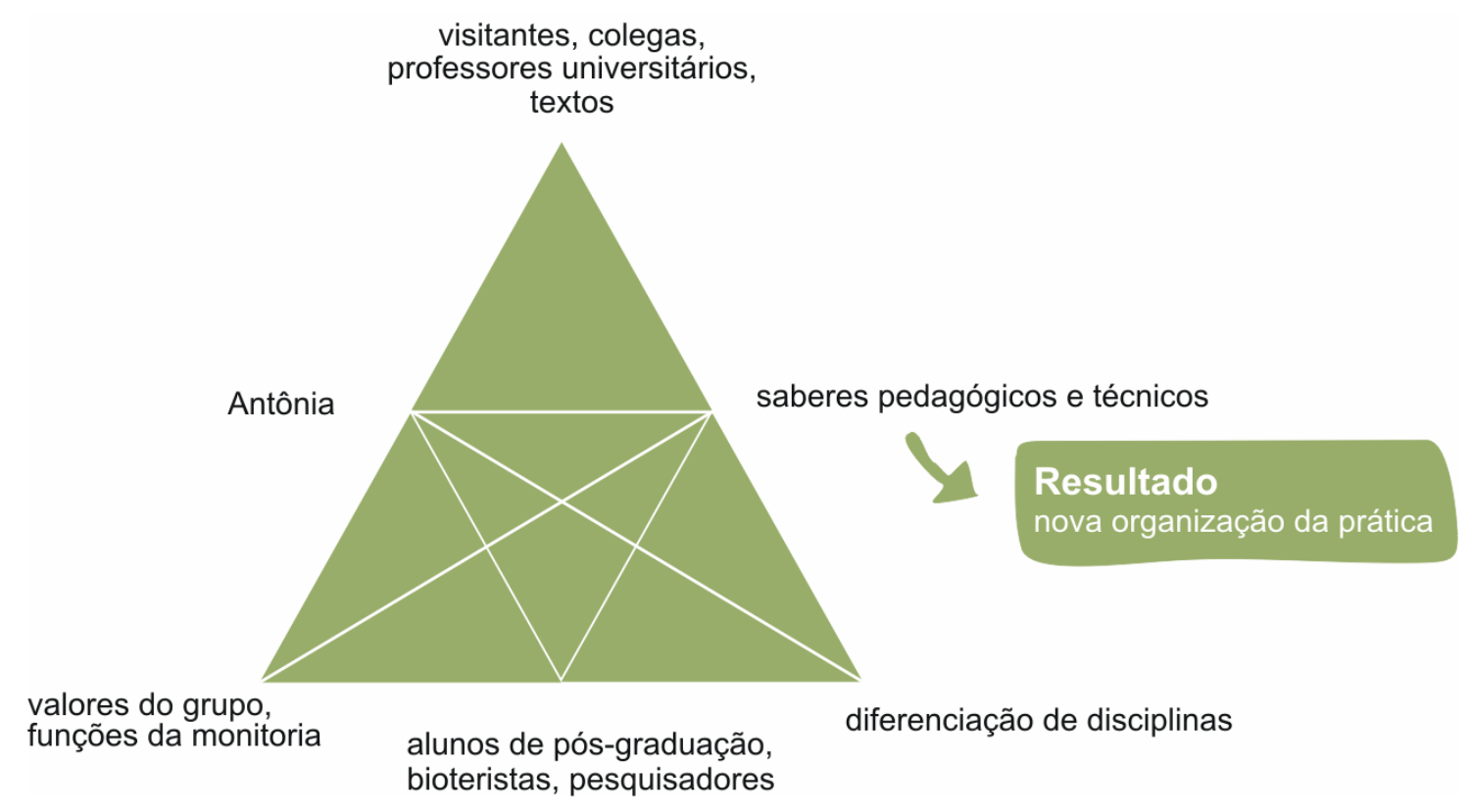

Figura 19 - Modelo de atividade de ensino/aprendizagem de Antônia.

\subsection{A ATIVIDADE DE VISITA ENQUANTO ATIVIDADE DE APRENDIZAGEM}

Considerando-se as sínteses apresentadas de atividades de visitantes e monitores, como seria, então, estruturada uma atividade de ensino/aprendizagem em um museu de ciências? Como estariam representados os diferentes elementos constituintes de um sistema de atividade coletiva? E, antes disso, é possível compreender a atividade de ensino e a atividade de aprendizagem, nos museus, como uma única atividade?

Para tentar responder a essas questões, alguns pontos são fundamentais: a relação sujeito/objeto e a natureza do objeto museal.

Considera-se aqui o sujeito da atividade como aquele diretamente relacionado ao objeto. Em outras palavras, seria o agente que, ao mesmo tempo em que transforma o objeto, é também transformado por ele. Nesse caso, é fácil imaginar o grupo de visitantes como o sujeito da atividade de aprendizagem. Ao interagir com o objeto do museu, o grupo de visitantes transforma esse objeto em objeto do conhecimento e, ao mesmo tempo, transformase em sujeito do conhecimento. É fácil imaginar também o museu como o sujeito da atividade de ensino: ao mesmo tempo que organiza os objetos da cultura e avalia essa organização, cria sua própria forma de organizar os saberes. 
Mas com que objeto esses sujeitos interagem? Os objetos museais corresponderiam ao elemento "objeto" do sistema de atividade?

Considerando a visão de Lotman (1994) de dualismo funcional do texto (e aqui incluindo o objeto museal como um tipo de texto), este não é simplesmente um objeto, ou seja, sua natureza não é imediatamente evidente. Para o autor, cada texto tem ao menos duas funções: representar/transmitir informações e gerar novos significados. A primeira função requer um compartilhamento de códigos entre quem produz o texto e aquele que recebe. Haveria, então, um modo mais "correto" de ler esse texto e essa leitura seria mais eficiente quanto maior a coincidência de códigos entre os sujeitos envolvidos. Dessa forma, um objeto museal (modelos, dioramas, legendas, objetos) cumpriria sua função ao transmitir a informação (conceito científico, conhecimento sobre o objeto, modo de usá-lo) do museu ao visitante. Ao se considerar somente essa função, fica-se limitado ao que a equipe do museu acredita ser a correta interpretação do objeto.

Entretanto, além de transmissor de informações, o objeto museal, ao possibilitar múltiplas interpretações e atividades, é ainda uma ferramenta para gerar significados. Essa segunda função do texto proposta por Lotman coloca a ideia de que o significado do objeto é formado não somente pela voz do museu mas por outros textos (ideias, conceitos, narrativas, modos de interação) trazidos pelo visitante ao usar e interpretar esse objeto.

Nesse sentido, é possível considerar que o objeto museal não corresponda ao elemento "objeto" do sistema de atividade coletiva, mas sim ao elemento "artefato", caso o objeto museal seja visto como uma ferramenta psicológica cultural ou um instrumento semiótico, um produto da atividade histórico-cultural humana. Cada objeto museal é fruto de um trabalho humano e carrega na sua materialidade experiências acumuladas e conhecimento produzido. Um animal taxidermizado em um diorama, por exemplo, traz vários conhecimentos humanos historicamente acumulados. O trabalho do taxidermista, do artista plástico, do cientista, do museógrafo, está presente nesses artefatos. Assim, o objeto passa por um processo de “musealização", identificado por Marandino (2001) como um processo de Transposição Museográfica e/ou Recontextualização. Ao ser exposto em um museu, o objeto museal/artefato poderá, então, ampliar e, ao mesmo tempo, limitar as possibilidades de criação de significado pelo visitante.

Outros artefatos também são utilizados em uma visita, como a linguagem do grupo de visitantes, as legendas, os textos expostos e a fala dos monitores. Esses meios foram produzidos para determinado fim, foram incorporados em um sistema de propósitos humanos 
e portam significado. São, portanto, instrumentos que o visitante usa para dar significado àquilo que encontra em um museu de ciências.

Mas, se o objeto museal não é o objeto dessa atividade, então com o que o grupo de visitantes interage em um museu de ciências?

Para uma reflexão sobre essa questão, é importante retornar às funções descritas para os signos. Além da função já mencionada de liberação do ser humano de suas impressões imediatas, o signo apresenta ainda a função de tornar possível o conhecimento (PINO, 2005), por ser algo por meio do qual conhecemos mais sobre o objeto. Mas para isso, o indivíduo necessita de uma familiaridade mínima com o objeto, "pois não pode captar o que o signo significa se não tiver um mínimo de conhecimento sobre o objeto" (PINO, 2005, p. 127):

as entidades que constituem o terceiro mundo de que fala Popper (ideias científicas, poéticas e artísticas), produzidas pela mente humana, adquirem, sim, uma existência objetiva e autônoma em relação a ela, mas na forma de signos que aguardam a ação interpretativa da mente para revelar sua significação. Os signos, como boa parte de seus objetos, constituem realidades materiais e, como tais, têm uma existência objetiva independente da subjetividade que os produz, mas só adquirem o seu status de signo pela dinâmica da atividade interpretativa do intérprete, pois o interpretante de Pierce só opera pela mente do intérprete. As ideias residem no ato de interpretar, o qual envolve o signo e seu intérprete.

Nessa exposição de Pino, fica claro que os signos, por meio do interpretante, são portadores das ideias das coisas, podendo ser considerados fontes para saber mais sobre os objetos. Mas para compreender essa ideia é necessário entender o que representa o termo interpretante.

Segundo Pino (2005), o signo de Peirce ${ }^{103}$ apresenta uma estrutura triádica, na qual a relação entre dois elementos (X e Y) só se torna possível graças a um terceiro elemento $(\mathrm{Z})$ :

${ }^{103}$ Charles Peirce (1839-1914), filósofo e matemático estadunidense, é considerado o fundador da Semiótica moderna. 


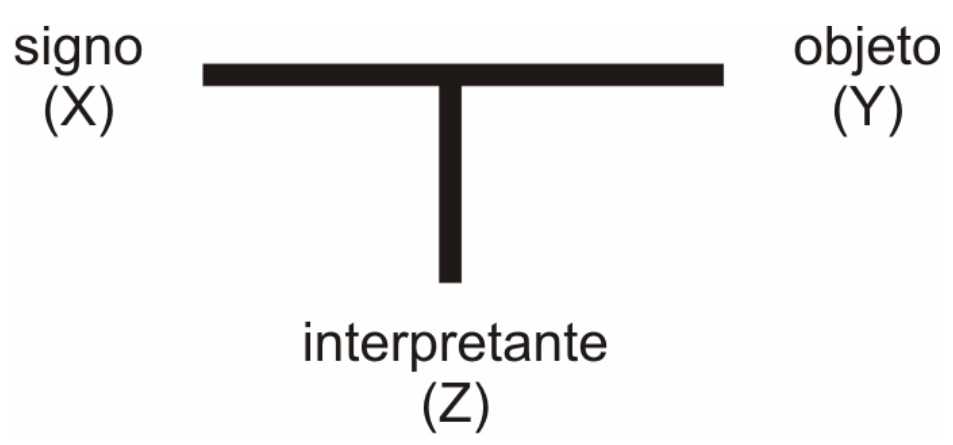

Figura 20: Estrutura triádica do signo em Peirce (retirado de PINO, 2005).

O signo é aquilo que está no lugar do objeto e, portanto, é algo material e perceptível, como um som ou uma imagem, que se constitui como um sinal desse objeto ausente. $\mathrm{O}$ objeto é a realidade material ou imaterial representada pelo signo em um determinado aspecto ou modo. Como o signo não representa a realidade do objeto em todos os aspectos, torna-se uma fonte permanente de conhecimento do objeto, sem esgotar a totalidade do saber relacionado a ele. Já o interpretante, embora pareça ser um terceiro elemento, "na realidade não é, pois os elementos da relação são dois (X - Y) e só podem ser dois" (PINO, 2005, p. 130). Ele desempenha a função de mediação entre o signo e o objeto, em uma mediação semiótica e não em uma mediação de articulação em que um terceiro elemento externo medeia a relação entre outros dois elementos (como o mediador diplomático). No caso da mediação semiótica, o interpretante não ocupa lugar intermediário entre o signo e o seu objeto nem tampouco se confunde com eles, mas está em cada um deles como elemento que os une. Se alguma relação é estabelecida entre signo e objeto, deve haver algum argumento para explicar por qual razão um signo representa determinado objeto.

Como se pode ver no exemplo da palavra "estrela" usado por Peirce, a idéia de estrela não está nem na palavra ou signo (X) nem na coisa ou objeto (Y), mas na relação entre elas. Sem a idéia, a palavra é um som vazio e a coisa é uma realidade opaca. A idéia une e, ao mesmo tempo, separa a palavra e a coisa, permitindo àquela representar esta. A idéia está, portanto, no representante $(\mathrm{Z})$ o qual, na semiose de Peirce, torna-se signo do mesmo objeto na mente do intérprete, dando origem a outro interpretante e assim indefinidamente. O interpretante constitui, portanto, o gerador de uma "rede de significações" [...] (PINO, 2005, p. 131). 
Nesse sentido, os signos são portadores de informações, o interpretante, que só farão sentido na mente de um intérprete que tenha algum conhecimento sobre o objeto. Ao interpretar, o sujeito cria novos signos em sua mente e, consequentemente, novos interpretantes.

Nesse aspecto reside a diferença entre as duas funções do texto de Lotman. Se o objeto museal é considerado como um transmissor direto de informação, em sua primeira função, assume-se que ele encerra uma única interpretação, que a interação do visitante se dá só e diretamente com ele. Entretanto, ao se considerar o objeto museal em sua segunda função, o de propiciador de múltiplas interpretações, supõe-se que ele seja um mediador, um signo que representa algo ausente.

Mas o objeto é presença de qual ausência? O que está ausente no museu de ciências e é significado pelo objeto?

É possível supor que os diversos públicos desses espaços interagem, utilizando-se de diferentes artefatos, com a cultura científica. $\mathrm{O}$ objeto da atividade de visita seria então a temática abordada pela exposição, com os diferentes saberes negociados e não somente o saber científico. Se o objeto for, por exemplo, a temática biodiversidade, o grupo de visitantes interage com o conhecimento científico na área, mas também com a forma com que esse conhecimento foi produzido e com a compreensão que ele possui sobre o tema. Por meio do signo, o objeto-artefato, o visitante pode dar um sentido próprio aos elementos expostos no museu.

Essa "mudança de categoria" tem grande importância na organização de exposições e atividades educativas em museus de ciências. Encarar o objeto como portador de múltiplas interpretações exige dos profissionais de museu uma nova postura na elaboração das estratégias de educação e comunicação. Assumir essa mudança significa organizar as práticas educativas de uma forma teórica e não empírica.

Um exemplo pode ser extraído da exposição em estudo. Há, na exposição de longa duração do Museu Biológico, uma sequência de oito biodioramas com diferentes espécies de jararaca, cujo intuito inicial seria o de "mostrar" as diferenças em padrão de colorido e desenho das serpentes em função de sua variação geográfica. Em geral, os visitantes observam as primeiras jararacas e, em seguida, desviam sua atenção para outros biodioramas, considerando todas as outras como iguais ou semelhantes (BIZERRA et al., 2008a).

Nessa proposta de expografia, espera-se que o visitante, a partir de suas impressões sensoriais, estabeleça uma relação entre o padrão polimórfico de indivíduos de serpentes da 
mesma espécie e sua distribuição geográfica (representada em uma mapa na legenda). Entretanto, a serpente, vista aqui como objeto, e não como artefato, encerra os objetivos dos organizadores da exposição, como se, por si mesma, falasse ao público os conceitos científicos selecionados pela equipe do museu. Observa-se, uma confusão entre o objeto museal e o objeto da aprendizagem. Se a serpente é considerada como o objeto da atividade de ensino/aprendizagem, e não como instrumento, o profissional do museu promove a utilização do pensamento empírico pelos visitantes, deixando-os com seus próprios dispositivos de resolução do problema.

Para os setores educativos de museus que tenham como objetivo promover o uso do pensamento teórico em suas atividades, uma nova organização das atividades seria necessária.

Ao considerar a serpente como instrumento, o profissional do museu deixa de procurar seu objetivo no objeto museal (na própria serpente), e passa a entendê-lo como um instrumento que serve para executar as suas ações em busca da concretização de seus objetivos. O objeto museal passa a ser então um artefato que o permitirá criar novas possibilidades de medição com o público, pois, enquanto artefato mediador, o objeto museal cristaliza os métodos e as operações e não as ações ou os objetivos (cf. LEONT'EV, 1978). É o que Leontiev (2004, p. 88) exemplifica pelo uso do machado, que

não responde ao único fim de uma ação concreta; ele reflete objetivamente as propriedades do objeto de trabalho para o qual se orienta a ação. O golpe do machado submete as propriedades do material de que é feito este objeto a uma prova infalível; assim se realiza uma análise prática de uma generalização das propriedades objetivas dos objetos segundo um índice determinado, objetivado no próprio instrumento. Assim, é o instrumento que é de certa maneira portador da primeira verdadeira abstração consciente e racional, da primeira generalização consciente e racional.

Nesse sentido, se os idealizadores da exposição das jararacas consideram a variação polimórfica de colorido e desenho como um tema importante a ser exposto e pretendem promover situações em que o visitante possa se utilizar do pensamento teórico, devem então organizar a exposição de tal forma que o visitante possa compreender relações entre os conceitos e não só fazer observações empíricas, a partir de comparações de traços externos apresentados.

Para Davídov (1988), o pensamento teórico opera com conceitos. Ter um conceito sobre o objeto é "saber reproduzir mentalmente seu conteúdo, construí-lo" (DAVÍDOV, 1988. p. 126, tradução nossa). Segundo o autor, "expressar o objeto em forma de conceito significa 
compreender sua essência”. A importância dessa estrutura de pensamento é que, ao compreender a essência dos objetos, o indivíduo entende como e por que algo se transforma e consegue resolver um problema não somente em relação a uma única situação, mas também a casos semelhantes.

Assim, uma possibilidade de organização seria criar situações problemáticas, em que o visitante necessite lançar mão de signos mediadores (objetos, conceitos, conhecimentos do grupo, conhecimentos do monitor) para resolver não somente aquela situação, mas também outras relacionadas, o que demandaria que o tema aparecesse em diferentes aparatos e em graus de aproximação diferentes.

Diferentemente das propostas que se inspiraram em teorias construtivistas, em que o modelo é visto como uma representação interna elaborada pelo visitante e como o centro de interesse do processo de aprendizagem, as propostas educativas que derivam da perspectiva histórico-cultural, pressupõem, geralmente, a elaboração anterior pelo museu de um modelo de conteúdo que poderá ser apropriado, recriado pelo visitante. O foco de interesse, no segundo caso, não está tanto no processo de modelização, mas sim na apropriação de modelos construídos a priori que permitam a resolução de certa classe de problemas (GARNIER; BEDNARZ; ULANOVSKAYA, 1996). Nesse sentido, os organizadores de uma exposição elaborada a partir de pressupostos da abordagem histórico-cultural de aprendizagem poderiam selecionar as leis gerais dos fenômenos a serem expostos e, a partir delas, criar um modelo germinal dessas relações. Com esse modelo em mente, poderiam procurar quais objetos museais se constituiriam como instrumentos, como promotores da experiência concreta do visitante (entendendo o concreto, não como o observável, mas como aquilo que mais representa o universal).

No exemplo da polimorfia das jararacas, quais são as leis gerais que estão em jogo? Tratase de um processo de mudanças dentro das espécies que podem vir a se constituir como um processo de especiação. Tratam-se, portanto, de conceitos mais essenciais como relação entre espécies (filogenia) e evolução. Mas como expor esses fenômenos de forma teórica e não empírica? Qual o modelo germinal da polimorfia das jararacas? Quais as contradições internas desses fenômenos que podem ser concretizadas na exposição?

Uma saída possível seria a elaboração de um modelo germinal que incluísse diferentes graus de particularização das principais relações envolvidas. Assim, a partir de um estágio mais geral do modelo, o da relação serpente - modificações no ambiente (físicas ou ecológicas), cria-se, ao longo da exposição, modelos mais particulares, trazendo a variação 
polimórfica dentro de espécies de serpentes e sua relação com variações geográficas e ecológicas, para então abordar as variações dentro de espécies de jararaca (Figura 21). Dessas relações mais gerais e mais particulares, podem ser extraídos seus conflitos e contradições, cujas soluções podem ser interpretadas e desenvolvidas pelos visitantes.

a.
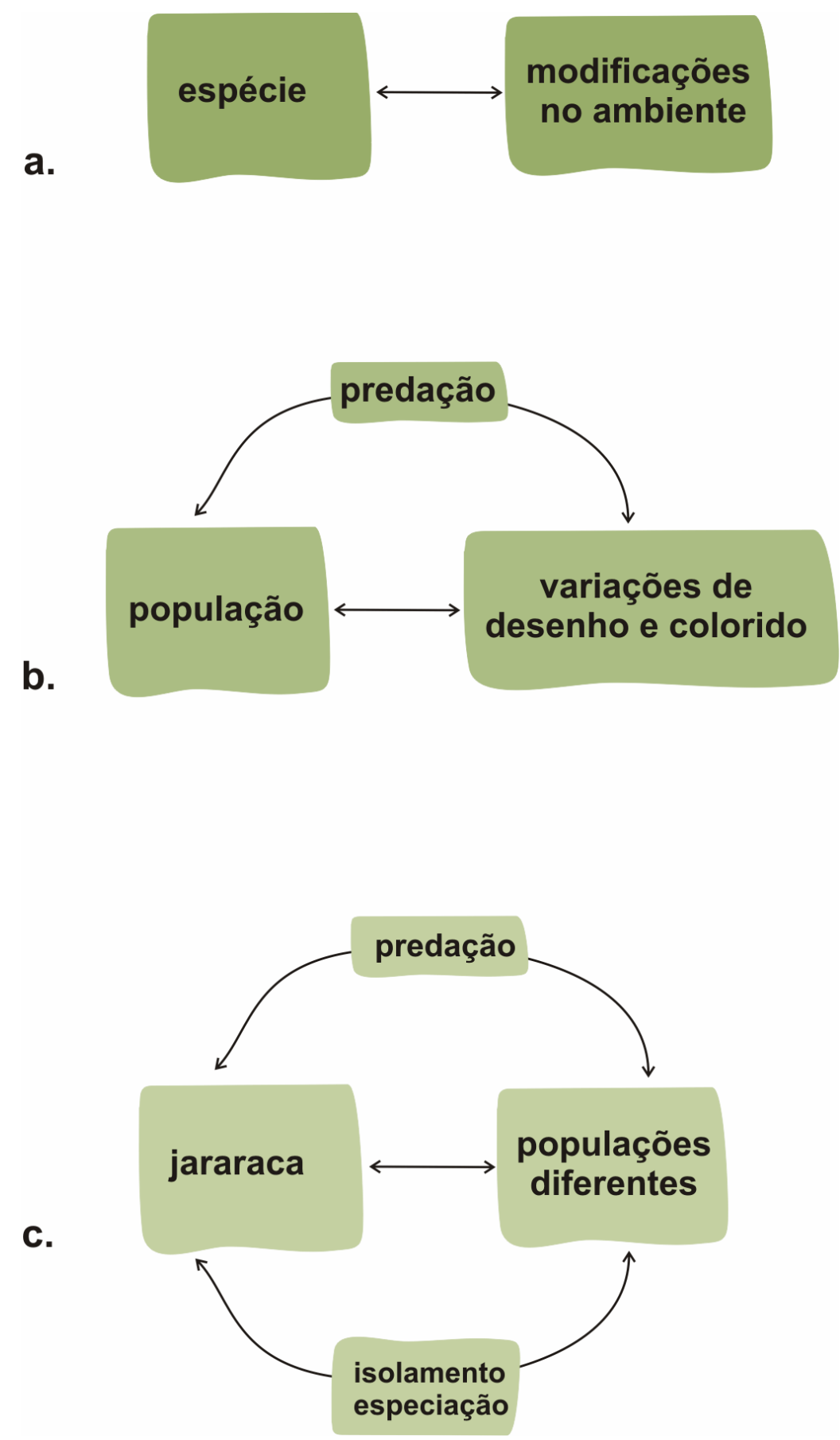

Figura 21 - Modelo germinal representativo da relação variação geográfica/polimorfia em três estágios de particularização. 
Uma das tensões do modelo mais geral, o da relação serpente - ambiente, por exemplo, é a constante necessidade das espécies sobreviveram às modificações locais que provocam alterações na composição do grupo, sugerindo um não equilíbrio. Essa tensão pode ser representada, por exemplo, com o uso de uma réplica de jararaca colocada em um aparato cujo substrato possa ser alterado pelo visitante. Ao mudar o ambiente, um determinado padrão de desenho e colorido pode ser mais ou menos eficiente em evitar predadores, o que poderia interferir na composição do grupo ${ }^{104}$.

Em um estágio menos geral, pode-se abordar as variações de colorido e desenho. Uma contradição imediata que surge ao se considerar o conceito de polimorfia é que forças em direções opostas podem atuar na seleção desse caráter. Se, por um lado, o padrão polimórfico pode ajudar na prevenção de uma imagem de busca por predadores (eles não formariam uma imagem única, o que dificultaria o encontro da presa), por outro, pode dificultar a otimização dos processos adaptativos de determinada população (como em serpentes que possuem um padrão ótimo de termorregulação ou são miméticas de um modelo venenoso).

No primeiro caso, há uma pressão favorável à fixação da polimorfia na população, no segundo, uma pressão negativa. Assim, na primeira situação, poderiam ser usadas réplicas de uma espécie de serpente, a boipeva, que possui grande variação de desenho e colorido, em dois dioramas de cerrado distintos: no primeiro, poderiam ser colocadas réplicas de um mesmo padrão e, no segundo, réplicas polimórficas. O visitante poderia ser convidado, então, a se imaginar um predador dessa serpente e a observar em qual dos dioramas sua busca se deu de forma mais eficiente.

Na segunda situação, a de pressão desfavorável à manutenção de polimorfismo, poderiam ser utilizados indivíduos da falsa coral Erythrolamprus aesculapii. Essa espécie é constituída por indivíduos de diferentes padrões relacionados a determinadas áreas de distribuição. A variação de padrões de desenho dessa falsa coral pode estar relacionada com os diferentes modelos de coral verdadeira presentes em cada região (MARQUES; PUORTO, 1991). Nesse caso, um polimorfismo de padrão de desenho pode não ser vantajoso para uma população de mímicos, pois os predadores visuais podem não associar seus diferentes padrões ao modelo venenoso da região ${ }^{105}$. Nesse caso, poderiam ser utilizadas réplicas de diferentes corais,

\footnotetext{
${ }^{104}$ Essa estratégia é usada por estagiários do Laboratório de Ecologia e Evolução, do Instituto Butantan, e parece oferecer boas opções de interação.

105 Sabe-se que essas relações não são tão imediatas e os próprios conceitos de modelo e mímico, no caso dessas falsas corais, trazem tensões e contradições: em alguns casos a serpente não venenosa pode se constituir como modelo. As resoluções e simplificações necessárias na transposição museográfica devem ser efetivadas pela equipe, considerando-se as características e demandas de seu público.
} 
falsas e verdadeiras, e o visitante poderia ser convidado a localizar quais são venenosas ou não, comparando-as a um modelo venenoso já identificado.

$\mathrm{Na}$ relação mais particular, da relação entre as variações no ambiente e o polimorfismo das jararacas, pode-se usar o exemplo da jararaca-ilhoa, serpente endêmica da Ilha da Queimada Grande, no litoral sul do Estado de São Paulo. Maquetes com variações no nível do mar que levaram à separação entre ilha (antes um morro) e continente, com o isolamento de um grupo de jararacas ancestrais, são objetos museais que podem exemplificar as variações dentro de uma mesma espécie e o movimento de especiação ao longo do tempo. O uso de outras espécies, como a caiçaca ou a jararacuçu, pode ilustrar mudanças de padrão dentro de uma mesma espécie, relacionadas a diferentes áreas de distribuição, mas não se constitui como uma boa ferramenta para aprofundamento do conceito. Observa-se aqui que talvez o exemplo das jararacas não seja o melhor a ser utilizado nos modelos que se relacionam a polimorfismo.

Uma intervenção como essa também traz as suas contradições (por exemplo, a escala de tempo, no caso do aparato de relações mais gerais, pode ser preterida e o exemplo pode levar a interpretações que cientificamente são consideradas errôneas). Mas é na resolução dessas contradições que os organizadores aprendem a construir novos modelos.

Com essa abordagem, é possível à equipe organizadora construir seu discurso expositivo com intencionalidade de possibilitar múltiplas interpretações do visitante. Com um modelo construído a priori, podem-se organizar os objetos museais de forma que o "exposto" não é mais a serpente, mas sim suas relações temporais e espaciais com o ambiente.

Isso parece paradoxal: ao se propor que um modelo seja construído pela equipe, sugere-se ao visitante qual o modelo que ele pode construir para compreender determinado fenômeno. Uma abordagem que se diz defensora da construção de múltiplos significados está definindo qual o significado a ser construído. Nessa visão, seria mais coerente a exposição já existente, em que os visitantes são convidados a olhar para os oito biodiromas e a observar por si mesmos a variação polimórfica. Cada um poderá construir o seu modelo, independentemente daquele apresentado pela equipe.

Para resolver essa situação, é necessário trazer as considerações de Hein (1998), apresentadas anteriormente (p. 42), sobre os dois componentes das teorias educacionais envolvidas no espaço museal: uma teoria do conhecimento e uma teoria da aprendizagem. Quanto à teoria do conhecimento, é importante um posicionamento no contínuo entre "o conhecimento existe independentemente do visitante" e "o conhecimento existe somente em 
ideias construídas na mente". No caso da aprendizagem, o posicionamento se dá entre "a aprendizagem consiste em um acúmulo constante de informações, fatos e experiências (resultando em conhecimento)" e "aprendizagem consiste da seleção e organização de sensações do entorno, com a construção de esquemas mentais".

Ao trazer a abordagem histórico-cultural, essa investigação assume que há um conhecimento social que é transformado pelo sujeito. Ao interpretar o modelo exposto, o visitante (individualmente ou em grupo) utiliza seus conhecimentos anteriores, seus valores e crenças, sua rede de conceitos, para dar significado ao que observa. Na interpretação, constrói o modelo que faz sentido na lógica apresentada. Por outro lado, a instituição tem um conteúdo a ser trabalhado, ela é a mediadora do conhecimento humano construído por gerações. Há um conhecimento já concretizado pela humanidade, disponível ao visitante por meio do objeto. Através dos objetos museais, o visitante tem acesso ao conhecimento historicamente elaborado e pode transformá-lo segundo a lógica que desejar, empiricamente ou teoricamente.

Assim, a equipe do museu caminha no sentido de organizar seus discursos expositivos de tal forma que o resultado da sua atividade seja a transformação do objeto museal da posição de objeto para a de artefato. O visitante, por sua vez, ao se apropriar do conhecimento veiculado pelo objeto museal, produz o mesmo resultado: a transformação do objeto em signo mediador.

Entretanto, esses papéis não são fixos. Como colocam Lave e Wenger (1996, p. 172), quando são consideradas as comunidades de práticas, em vez da relação professor/aluno, temse diversidade de atores e, assim, outras formas de relações de participação. Nesse sentido, o visitante ora pode ser um membro experiente em determinada comunidade, assumindo o papel de ensino, ora pode ser um novato, um aprendiz, em outra comunidade onde, posteriormente, pode vir a ser veterano. O setor educativo, ao avaliar como o público interage com o discurso exposto, aprende novos significados não somente da prática educativa, mas também dos conceitos científicos em jogo.

Vê-se aqui que há uma atividade mais ampla, que envolve público e museu, o trabalho de re-significação de objetos museais, uma atividade de ensino/aprendizagem da cultura musealizada. Essa atividade, vista à luz dos ciclos expansivos de Engeström (1999a, b), poderia ser esquematizada conforme a Figura 22. 


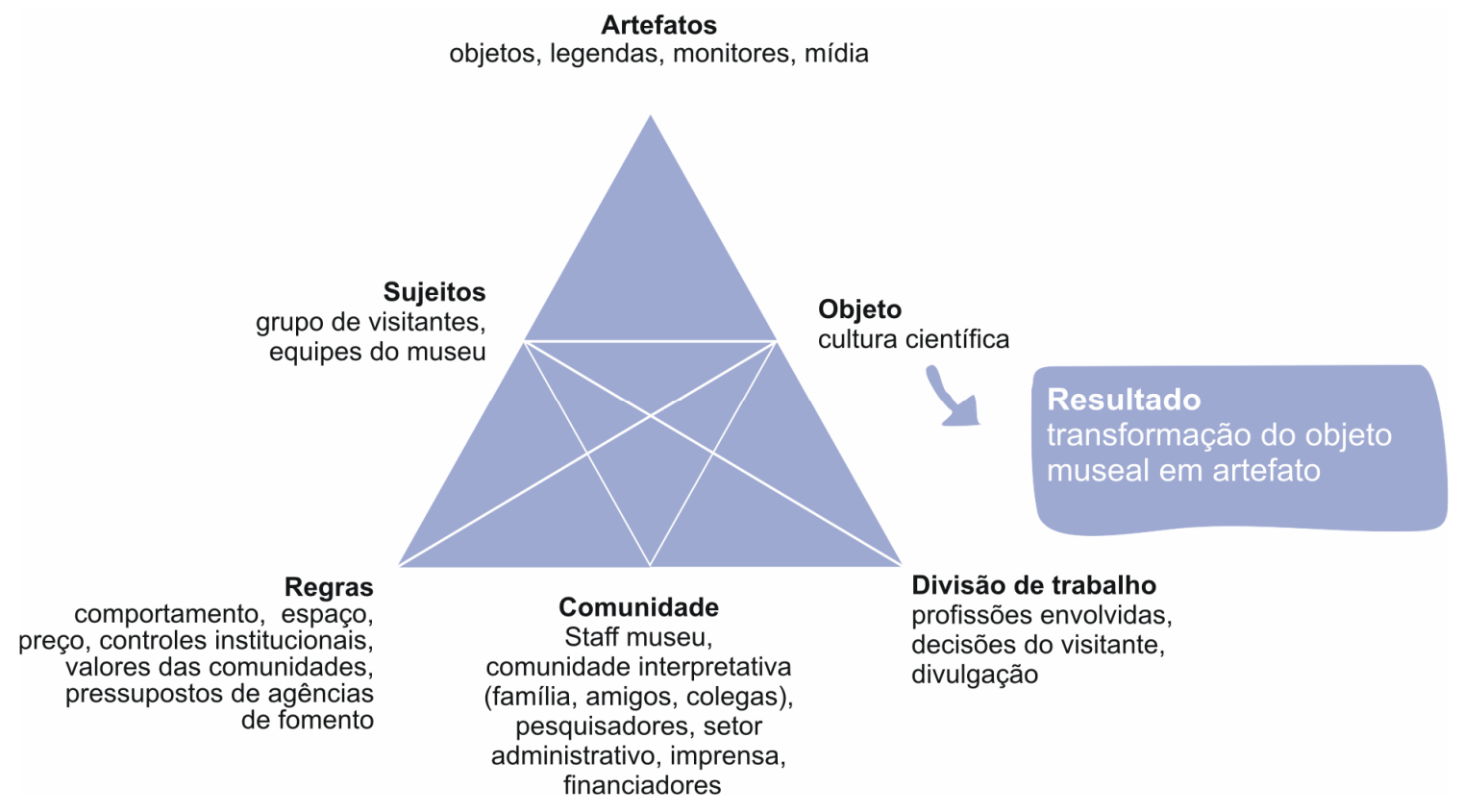

Figura 22 - Modelo para a atividade de ensino/aprendizagem em um museu de ciências.

Essa atividade, ou melhor, essas atividades são compostas por vários microciclos, como os analisados anteriormente, e, por sua vez, fazem parte de uma estrutura maior, os macrociclos de atividade. Considerando-se a análise histórica das ações de educação e comunicação em ciências do Instituto Butantan, é possível situar os atuais ciclos de aprendizagem no terceiro macrociclo encontrado, em um ponto em que o processo de externalização já atingiu o seu pico e o de internalização de novas práticas está em ascensão.

Com o novo direcionamento das ações educativas e comunicacionais iniciado nos últimos anos, visando outros conteúdos além dos animais peçonhentos, novas práticas tornam-se necessárias, outros saberes são exigidos, em um processo de "internalização institucional” em que diferentes sujeitos apresentam-se em constantes tensões e negociações.

O Museu Biológico, ao se constituir como o representante histórico do discurso expositivo relacionado aos animais peçonhentos, encontra-se em uma situação conflituosa: a manutenção do tema "animais peçonhentos" em um momento em que a educação e a comunicação do institucionais caminham para a formação de uma nova significação do Instituto Butantan pela sociedade. A resolução desse conflito exige o deslocamento do tema, sua consideração não como célula-mater da prática educativa, mas como imersa em uma rede de conhecimentos produzidos e reproduzidos pela instituição. Nesse movimento, seria importante que os conteúdos temáticos da ciência deixassem de ser o centro da práxis educativa e passassem a ser vistos como um dos elementos da cultura científica. 
Portanto, nessa perspectiva, vê-se que o Museu Biológico do Instituto Butantan pode se constituir como uma estrutura "mediadora", facilitadora das múltiplas possibilidades de interação entre o sujeito e a cultura. Caberia, portanto, ao seu setor educativo, propiciar possibilidades de experimentação da cultura científica aos seus diferentes públicos. Mas, para isso, é necessário compreender qual o potencial semiótico dos objetos-artefatos, quais são as ferramentas culturais presentes nos museus de ciências mais adequadas para determinadas atividades e conteúdos e, principalmente, qual a ideia de ciência considerada. 
Capítulo 5

Considerações finais 



\section{CONSIDERAÇÕES FINAIS}

Esse trabalho se propôs a compreender como seria estruturada uma atividade de aprendizagem em um museu de ciências, bem como a compreender como estariam representados os diferentes elementos constituintes de um sistema dessa atividade coletiva nesses espaços.

Assumiu-se que a atividade de aprendizagem inclui um componente de ensino e um componente de aprendizagem, sendo, portanto, considerada uma atividade de ensino/aprendizagem. Sabe-se que esses sistemas de atividade correspondem a duas atividades distintas, visto que o objeto, os motivos, as ações do sujeito que ensina, não são os mesmos do sujeito que aprende. Como ressalta Leontiev (2004), o que distingue uma atividade de outra é o seu objeto, cujo reflexo psíquico é o motivo, que lhe confere determinada direção. Na relação professor/aluno, um dos objetos das atividades do professor é a transformação do aluno e um dos objetos das atividades do aluno é o próprio conteúdo da aprendizagem, os conhecimentos do mundo.

Entretanto, ao se trabalhar com o conceito de ciclo de aprendizagem expansiva, em que os microciclos de ensino e de aprendizagem combinam-se em estruturas mais amplas, os ciclos de aprendizagem expansiva, é possível compreender essas atividades como constituintes de um único ciclo. Os resultados das atividades do visitante influenciam a prática dos profissionais do museu e vice-versa, em um ciclo de internalização e externalização constantes de conceitos e práticas.

Para isso, é necessário ver o resultado de uma atividade como o seu objeto transformado, ou seja, vê-lo como o fruto da atividade do sujeito na transformação de um objeto em outro. Nos museus de ciências, um resultado da atividade educativa é a musealização do objeto, a seleção e a significação de determinados elementos da cultura científica em um determinado contexto. Essa atividade mais geral, de transformação de um objeto individual em um objeto coletivo, é constituída por numerosas outras atividades, em diferentes níveis, cada uma delas transformando objetos e formando um resultado mais abrangente visto a longo prazo, com diferentes sujeitos envolvidos.

Vale trazer as palavras de Lave e Wenger (1996, p. 172):

Em qualquer comunidade de prática, o processo de reprodução da comunidade - uma estruturação historicamente construída, contínua, conflituosa, sinergética, da atividade e das relações entre participantes - tem de ser decifrado a fim de se entender as formas específicas de participação periférica legítima ao longo do tempo. Isso requer uma concepção mais 
ampla das biografias individuais e coletivas do que o segmento único encerrado no estudo dos "alunos". Assim, começamos a analisar as formas cambiantes de participação e identidade das pessoas que se engajam em firme participação numa comunidade de prática desde sua entrada como novato, passando por seu tornar-se um veterano em relação a novatos, até o ponto em que esses novatos mesmos se tornam veteranos. Em vez da díade professor/aluno, tem-se um campo ricamente diverso de atores essenciais e, com isso, outras formas de relacionamento de participação.

Assim, ao mesmo tempo em que a equipe do museu caminha no sentido de organizar seus discursos expositivos e os visitantes, por sua vez, se apropriam desse discurso, em duas atividades distintas, ambas fazem parte de uma atividade coletiva maior, de significação dos objetos museais por diferentes sujeitos, em diferentes momentos, e com objetos em constante transformação. Nesse movimento, as contradições, internas e externas aos sistemas da atividade de aprendizagem em uma instituição de pesquisa são inerentes, mas constituem-se também como geradoras de novas tentativas de mudança. Entender como essas tensões foram consideradas pelos sujeitos históricos torna-se importante para as novas tentativas de resolução das contradições e dos conflitos atuais.

Daí a necessidade de se olhar para os ciclos anteriores de uma atividade de aprendizagem na perspectiva do educador de museu. Como coloca Engeström (1999a, p. 35, tradução nossa), “a reorquestração das múltiplas vozes é extremamente facilitada quando as diferentes vozes são vistas historicamente como camadas em um pool de competências complementares dentro dos sistemas de atividade." Ao elaborar um modelo de transformações em escala macro, foi possível contextualizar as negociações em trânsito nos atuais ciclos e microciclos de atividade de aprendizagem ativos no Museu Biológico do Instituto Butantan, com uma nova perspectiva. Dessa forma, por exemplo, o que antes era visto como uma repetição de práticas, passou a ser visto como uma re-produção de práticas estabelecidas historicamente por diferentes sujeitos que, em variados graus, agregaram e agregam novos conhecimentos ao entrarem em atividade, constituindo-se, elas mesmas, como novas práticas, em um movimento em espiral.

Usar a atividade como unidade de análise em diferentes escalas permitiu ainda empregar conceitos centrais da teoria histórico-cultural de aprendizagem em interpretações variadas. Ao se considerar o conceito de zona de desenvolvimento imediato, por exemplo, foi possível utilizá-lo tanto como a distância entre as habilidades de resolução de problemas de um visitante só e suas habilidades quando está em grupo ou entre o grupo de visitantes quando interage sozinho (família G7) e quando resolve problemas com a ajuda do monitor. Foi 
possível ainda utilizá-lo como a distância entre o conhecimento disponível socialmente ao indivíduo (práticas encontradas por Antônia ao chegar ao Museu) e seu conhecimento ativo, sua experiência cotidiana (novas práticas elaboradas) (cf. DAVYDOV; MARKOVA, 1983). Ou, ainda, como a distância entre as práticas cotidianas de resolução de problemas e a forma historicamente nova da atividade gerada coletivamente para solucionar as tensões emergidas.

Nessa perspectiva, a estrutura da atividade de aprendizagem construída nesta investigação (sintetizada na Figura 22) deve ser vista, portanto, como algo dinâmico, em constante movimento. Entretanto, nesse devir, alguns elementos da atividade de aprendizagem em museus mantêm-se presentes e tornam-se evidenciados. Como observado, o posicionamento do objeto museal na atividade de aprendizagem é uma questão central.

Os museus, com sua variedade de acervos, respondem a uma necessidade humana de reprodução do patrimônio e, ao promover sua preservação e extroversão, podem organizá-los empírica ou teoricamente. Dependendo da concepção de educação e ciência apresentada pelos profissionais de um museu, um objeto museal pode ser apresentado ou observado a partir de suas características externas, constituindo-se como um importante elemento para o desenvolvimento da generalização empírica. Mas pode também ser apresentado ou observado em sua essência, promovendo o uso do pensamento teórico.

O fato do museu ter como elemento central a significação do objeto tem relação imediata com a práxis educativa. O discurso expositivo do museu, por si, com uma mínima organização, permite que diferentes sujeitos observem, estabeleçam relações, façam abstrações. A diversidade de objetos museais apresenta-se como uma boa ferramenta para possibilitar um maior contato do sujeito com a variedade de objetos relacionados a determinado conceito ou prática. Ao ter um maior leque de experiências sensoriais, maior a de observação de diferentes atributos externos de determinada prática ou conceito e, consequentemente, mais segura a generalização daqueles conteúdos.

Entretanto, se a equipe do museu deseja uma atividade educativa que promova uma abstração baseada no sensorial, mas que busque a essência dos conceitos e práticas expostos, que traga elementos do universal de eventos e fenômenos, é interessante que a organização de seu discurso expositivo transcenda o objeto museal, colocando-o na condição de artefato mediador entre os diferentes sujeitos e a cultura científica.

Os referenciais utilizados nessa investigação, o da Teoria da Atividade e o de Comunidades de Prática, baseados nas ideias de Vigotski, oferecem dicas importantes e variadas de organização da atividade educativa. O uso de modelos germinais e de situações- 
problema, a seleção de conceitos e práticas nucleares, a promoção da ascensão do abstrato ao concreto, o movimento entre ações e operações, a zona de desenvolvimento imediato como propulsora do desenvolvimento, a mediação semiótica e social são elementos que podem ajudar na organização da prática educativa em museus de ciências.

Caso seja intencionalidade da equipe educativa do museu que a aprendizagem nesse ambiente se constitua como atividade, ou seja, que o processo de aprendizagem dos visitantes, monitores, coordenadores, bioteristas, entre outros sujeitos, não seja um epifenômeno, mas sim a resposta à intenção de aprender, a perspectiva trazida para essa reflexão representa um modo de organização do discurso expositivo que permite otimizar os processos de aprendizagem nos museus. Na perspectiva da Teoria da Atividade, a compreensão da intencionalidade como um dos elementos necessários para que ocorra essa organização implica que a equipe do museu compreenda também os elementos que constituem sua prática educativa.

A intencionalidade é um elemento também relacionado aos públicos do museu e não somente à sua equipe. Os visitantes de museu podem querer aprender ou não. Mas, caso seja interesse da equipe educativa, como possibilitar aos sujeitos que a aprendizagem não seja uma ação constituinte de alguma atividade mas a atividade em si? Ou seja, como a organização do discurso expositivo pode criar a intencionalidade da aprendizagem?

Aqui, é necessário considerar prioritariamente o elemento que Leontiev traz como o desencadeador da atividade: o motivo. Na ótica do visitante, por exemplo, é possível pensar que a suas necessidades são variadas, gerando motivos diferentes, que dão sentido a determinadas atividades. Diversão, integração do grupo e aprendizagem são alguns dos motivos comuns em uma visita ao museu ${ }^{106}$. Para Davydov (1999c), Leontiev apresenta a atividade como constituída de necessidades, tarefas, ações e operações, mas não traz um elemento de extrema importância: o desejo, enquanto núcleo básico de uma atividade. Para o autor, esse elemento é relevante pois, junto com as necessidades, formaria a base sobre a qual as emoções funcionariam. As emoções seriam, então, inseparáveis das necessidades. Como ressalta o autor (DAVYDOV, 1999c, p. 41, tradução nossa):

106 No Curso de Pós-Graduação "Educação em Museus: Pesquisas e Práticas”, ministrado por Martha Marandino e Paulette McManus, em setembro de 2005, a segunda pesquisadora trouxe dados ingleses sobre os motivos que levam famílias a visitarem museus de ciências: $26 \%$ buscam descobertas e aprendizagem, $20 \%$ procuram passeio/recreação, $18 \%$ visitam devido à reputação do museu, $17 \%$ possuem interesse em ciência e 8\% estão museando (MARANDINO, 2007). 
Em seus trabalhos, Leontiev afirma que as ações são conectadas às necessidades e motivos. Discordo desta tese. Ações, como formações integrais, podem ser conectadas somente com necessidades baseadas em desejos - e as ações ajudam na realização de certas tarefas a partir dos motivos.

Assim, para Davydov (1999c, p. 41, tradução nossa), os elementos da atividade passariam a ser: "desejos, necessidades, emoções, tarefas, ações, motivos para as ações, meios usados para as ações, planos (perceptivo, mnemônico, de pensamento, criativo) - que se referem à cognição e, também, à vontade."

É importante ressaltar que a relevância da emoção para o desenvolvimento do sujeito aparece, antes, nos trabalhos de Vigotski. Segundo González Rey (2000), apesar desse autor usar o termo emoção de forma dispersa ao longo de sua obra, é possível perceber que a integração entre o cognitivo e o afetivo permanece presente em seus trabalhos: Vigotski confere à emoção um lugar equivalente ao dos processos cognitivos no desenvolvimento psíquico, mesmo que não explicite essa suposição de forma aprofundada.

Como afirma González Rey (2000, p. 137, tradução nossa),

ao outorgar à emoção um status similar ao da cognição, na constituição dos diferentes processos e formas de organização da psique, Vigotski está sugerindo a independência das emoções, em sua origem, dos processos cognitivos, e integrando as emoções dentro de uma visão complexa da psique que representa um importante antecedente para a construção teórica do tema da subjetividade.

Para Davydov (1999c), as emoções são mais importantes que os pensamentos, pois são a base para as diferentes tarefas que cada sujeito atribui a si, incluindo as tarefas do pensar. As emoções capacitam o indivíduo a se colocar em determinadas tarefas e, ainda mais importante, conferem-lhe a capacidade de decidir se existem meios (físicos, espirituais e morais) necessários para a realização de seu objetivo. As emoções e as necessidades antecedem as ações humanas que, portanto, estão repletas de sentidos subjetivos. Como afirma González Rey (2000, p. 145, tradução nossa):

As necessidades humanas integram-se por meio de numerosos sentidos subjetivos e configuram os motivos. Todo motivo é uma combinação particular de sentidos subjetivos que, organizados nas mais diversas áreas de atividade humana, representa uma integração qualitativa nova, de onde a necessidade constituinte fundamental se integra qualitativamente em uma nova unidade, que define a produção de sentidos subjetivos nos diferentes espaços da vida do sujeito. O nível diferenciado de produção de sentidos subjetivos a partir de uma necessidade se dá por sua conversão em motivo. 
Nessa perspectiva, os indivíduos atuam em estado de necessidade e, nessa atuação, geram novas necessidades, que são organizadas baseadas nas emoções já existentes. $\mathrm{O}$ surgimento de novas necessidades psicológicas é, para o autor cubano, fonte de emoções qualitativamente diferentes que, por sua vez, são integradas em novas redes com outras emoções em momentos concretos da atividade, conduzindo ao surgimento de novas necessidades.

O afeto, construído por meio das necessidades, emoções e sentimentos, constitui-se como aspecto essencial do sistema psíquico, no qual esses processos, "tanto os afetivos, como os cognitivos, não funcionam de modo isolado, mas sim como momentos de um sistema complexo, que Vigotski coloca em diferentes momentos de sua obra, no desenvolvimento, na personalidade e na consciência" (GONZÁLEZ REY, 2000, p. 143, tradução nossa).

Vê-se assim que ao sugerir a independência entre emoção e cognição, Vigotski (2001, p. 16) não sugere a separação desses elementos:

Como se sabe, a separação entre a parte intelectual da nossa consciência e a sua parte afetiva e volitiva é um dos defeitos radicais de toda a psicologia tradicional. Neste caso, o pensamento se transforma inevitavelmente em uma corrente autônoma de pensamentos que pensam a si mesmos, dissocia-se de toda a plenitude da vida dinâmica, das motivações vivas, dos interesses, dos envolvimentos do homem pensante e, assim, se torna ou um epifenômeno totalmente inútil, que nada pode modificar na vida ou no comportamento do homem, ou uma força antiga original e autônoma que ao interferir na vida da consciência e na vida do indivíduo, acaba por influenciá-las de modo incompreensível. Quem separou desde o início o pensamento do afeto fechou definitivamente para si mesmo o caminho para a explicação das causas do próprio pensamento, porque a análise determinista do pensamento pressupõe necessariamente a revelação dos motivos, necessidades, interesses, motivações e tendências motrizes do pensamento, que lhe orientam o movimento nesse ou naquele aspecto. De igual maneira, quem separou o pensamento do afeto inviabilizou de antemão a influência reflexa do pensamento sobre a parte afetiva e volitiva da vida psíquica, uma vez que o exame determinista da vida do psiquismo exclui, como atribuição do pensamento, a força mágica de determinar o comportamento do homem através de seu próprio sistema, assim como a transformação do pensamento em apêndice dispensável do comportamento, em sua sombra impotente e inútil.

Emoção e cognição fazem parte, portanto, de um "sistema semântico dinâmico" que representa a concepção de que em toda ideia existe uma relação afetiva do homem com a realidade representada nessa ideia. Nessa relação, há o movimento que vai das necessidades e motivações do indivíduo ao sentido de seu pensamento, e o inverso, da dinâmica do pensamento à atividade concreta do sujeito. 
Como coloca Lanner de Moura (1998), "não basta olhar para as coisas e para a vida; é preciso sentir e pensar sobre elas para conhecê-las". E pensar e sentir são dois processos intimamente relacionados que, no contexto museal, tornam-se ainda mais evidentes.

É aceita entre os profissionais de museu, a ideia de Wagensberg (2001) de que as interações entre sujeitos e aparatos expositivos não devem ser somente hands on (interatividade física) e minds on (interatividade mental), mas também heart on (interatividade emocional).

Em uma exposição, os intervalos de tempo disponíveis para centrar a atenção de um visitante são pequenos. Para que o ânimo e o humor do visitante recebam algum tipo de descarga emocional, necessita-se abordar seu aspecto mais genuinamente cultural. $\mathrm{O}$ objeto ou o evento expostivo pode mostrar nuances estéticos, éticos, morais, históricos ou simplesmente de sua vida de cada dia, que conectem com algum aspecto sensível do visitante ... É quando o uso da arte se faz legítimo para comunicar ciência. É o que faz que, no fundo, todos os museus possam ser distintos (WAGENSBERG, 2001, p. 349).

Ou seja, é recorrente entre educadores de museus de ciências o valor de que as emoções são fundamentais para a qualidade da experiência de visita. Para o autor catalão, tanto a interatividade manual quanto a mental não deixam de ser emocionais e, portanto, a interatividade emocional pode ser considerada a "interatividade total" de um museu de ciências.

Em um museu em que as serpentes, os sapos, as aranhas e os escorpiões são as maiores estrelas, as emoções tomam uma dimensão especial. Expressões de nojo, medo, admiração são facilmente observadas entre os visitantes do Museu Biológico. Esses sentimentos provocam emoções que se relacionarão com os sentidos que cada visitante dá ao objeto museal, provocando novas necessidades, sejam de afastamento ou de aproximação do discurso expositivo. Nessa perspectiva, surge então a questão: é possível organizar esse discurso de tal forma que novas negociações entre emoções e sentidos subjetivos sejam estabelecidas?

Uma dica para avançar nesse questionamento é fornecida por Ross Kiester, um pesquisador estadunidense que, ao refletir sobre a práxis educativa relacionada à conservação ambiental, sugere a necessidade de se considerar os conceitos kantianos de belo e sublime. Kiester (1996) considera que, na lógica de Kant, o belo encerra as características de um objeto, em uma forma definida, enquanto o sublime é encontrado na contemplação dos objetos, que adquirem forma indefinida e suscitam fortemente a imaginação. Para atingir o 
sublime, é necessário desvendar o objeto em sua história, em sua relação com o mundo. Ao conhecer o objeto para além dele, o sujeito pode desenvolver outras relações que o belo não permite, por sua hermeticidade. Enquanto o belo encanta no limite da superfície e da aparência, o sublime relaciona-se com o assombroso, o profundo, com aquilo que provoca comoção.

Essa visão possui elementos semelhantes à distinção feita por Davidov entre o conhecimento empírico e o conhecimento teórico: ambas as abordagens, a de Kiester e a de Davidov, apresentam formas diferentes de entender o mundo, uma baseada nas características imediatas e outra na transcendência do objeto. Observa-se nessas ideias a possibilidade de um caminho interessante para a organização do discurso expositivo do museu: o que é o sublime em relação ao objeto selecionado? O que pode gerar novas emoções aos sujeitos que interagem com esse discurso, emoções essas que não fiquem presas às sensações imediatas impostas pela presença do objeto? Tirar o objeto do plano empírico e colocá-lo como mediador de conhecimentos humanos construídos historicamente apresenta-se como um passo inicial desse caminho.

Entretanto, o caminho é longo. Vale relembrar questões colocadas na apresentação desta investigação: como os museus de ciências podem tornar os indivíduos a eles relacionados partícipes da construção do conhecimento humano ali re-produzido? Como os museus podem participar do processo de constituição e ressignificação do patrimônio, considerando seu público como composto por sujeitos ativos nesses processos, que atribuem valores e significados a esse patrimônio?

Sabe-se que os museus, incluindo o Museu Biológico, não somente expõem a ciência mas, como observado, acabam por criar tipos particulares de ciência, emprestando-lhe sua própria marca de legitimização. Ao definir certas práticas e artefatos como pertencentes ao "reino" da ciência, de uma ciência que o público deveria ter conhecimento, atuam como filtros culturais (Macdonald, 1998). Cabe aos profissionais de museus indagarem-se quais as noções de ciências mobilizadas para justificar representações particulares em suas práticas educativas, quais grupos e negociações estão envolvidos na preservação e na extroversão do patrimônio. Cabe a eles terem em mente que quando algo é eleito para ser comunicado, outro é silenciado. Isso inclui a educação em diferentes elos da cadeia operatória museal.

Um modelo de instituição museal, que também apresenta suas contradições e tensões internas, mas que caminha na direção de considerar o indivíduo como sujeito ativo na construção do patrimônio musealizado, que incorpora a atividade educativa em toda a 
extensão da cadeia operatória, é o de ecomuseu.

Embora definir um denominador comum de um modelo de ecomuseu ${ }^{107}$ possa gerar o risco de simplificação, de redução da realidade ou limitação de suas transformações, pode-se tentar caracterizar globalmente o ecomuseu como uma organização de vocação sociocultural que utiliza a história e a educação como instrumentos privilegiados nos processos de reconhecimento, de identidade e de pertencimento. O ecomuseu caracteriza-se, sobretudo, por seu enraizamento em um espaço autodeterminado, lugar de mobilização voluntária em torno de um patrimônio humano. Não há edificações, o museu não está restrito a um prédio. Apresenta uma gestão coletiva, promotora da negociação entre diferentes atores. Seus objetos de estudos são variados, envolvendo os objetos da vida cotidiana, as paisagens, as construções arquitetônicas, o saber-fazer, os testemunhos orais.

Nesse sentido, o ecomuseu pode ser entendido como uma atividade coletiva voltada para a conservação, a apresentação e a valorização de patrimônios naturais e culturais mantidos por uma determinada população, representativos de um meio de vida e de trabalho (DESVALLÉES, 2000). Representa, portanto, um espaço de organização de ações, em que a população, ao materializar seus conflitos, seus desejos, suas histórias, seus valores, em objetos a serem expostos, constrói a imagem de si mesma que ela deseja que seja mostrada. $\mathrm{O}$ ecomuseu passa a ter um papel catalisador no processo de construção de um patrimônio significativo para a população (e, portanto, do fortalecimento de sua identidade cultural). Representa também o local de extroversão, de apresentação para a população local e para os “estrangeiros" de sua memória coletiva.

É clara a importância dessa ação no processo de construção dos sujeitos, no sentido em que o fortalecimento das memórias coletivas e individuais possibilita o reconhecimento de sua ação sobre o mundo. A atuação conjunta entre o ecomuseu e outros contextos educativos de um território (como a rádio local, o jornal, a escola, a família, entre outros) fortalece os sentimentos de identidade e pertencimento, fundamentais para o desenvolvimento do território.

Veem-se, na construção contínua de um ecomuseu, sujeitos em constante atividade de ensino/aprendizagem. Nesses espaços, a educação, entendida como um processo de

\footnotetext{
${ }^{107}$ Além dos ecomuseus, outras modalidades museais surgiram com a perspectiva de incluir a sociologia em suas referências. Museus comunitários, casas de memória, museus de vizinhança, museus de sítio e ao ar livre, entre muitas outras formas, apareceram como variantes da Nova Museologia, movimento fortalecido na década de 70, fruto de um descontentamento com a concepção dos museus tradicionais e suas formas de ação. Esses museus reivindicatórios, então chamados Museus de Sociedade, iniciaram uma desconstrução das ideias e práticas das instituições museológicas consideradas enciclopédicas e elitistas.
} 
constituição do sujeito por meio de outros sujeitos e objetos mediadores, está presente não somente no momento de extroversão do patrimônio cultural, como na maioria dos museus tradicionais, mas também na seleção de objetos a serem musealizados, na manutenção desses objetos e no gerenciamento dessas e outras numerosas ações.

Não se defende aqui que todos os museus, para serem considerados espaços educativos, devam ter o mesmo grau de inserção educativa que os ecomuseus. O que se pretende é trazer outros modelos, que vistos à luz da Teoria da Atividade, possam ajudar a pensar sobre novas possibilidades de atividade educativa para os museus de ciências. Como dito na apresentação deste trabalho, não há pretensão em resolver essa questão, mas sim levantar pontos, contraditórios ou não, que avancem na reflexão sobre a educação em museus.

Acredita-se que essa pesquisa tenha contribuído para isso, principalmente no que tange à compreensão do processo de ensino-aprendizagem em um museu de ciências a partir de referenciais pouco utilizados nas pesquisas na área. Ambos referenciais adotados, a Teoria da Atividade e a Aprendizagem Situada, com o conceito de Comunidades de Prática, procuram entender o contexto em que ocorre a aprendizagem, consideram a construção social do conhecimento e têm a atividade como elemento central.

Entretanto, algumas diferenças são encontradas entre essas teorias. A Teoria da Atividade dá importância à persistência de elementos como as ferramentas, os valores e as instituições na construção do aspecto histórico de um sistema de atividade. A Aprendizagem Situada, por sua vez, não prioriza a durabilidade dos elementos, nem requer que sejam analisados independentemente de uma situação particular. Ao reforçar a situabilidade da aprendizagem, tira o foco da continuidade do processo de aprendizagem, embora Lave e Wenger (1991) ressaltem que a aprendizagem fora da escola, mesmo tendo um caráter situado, é contínua ao longo da vida.

Se, por um lado, a Teoria da Atividade fornece uma estrutura para melhor compreender cada um dos elementos de uma visita ao museu, bem como os processos interativos que ocorrem entre eles, por outro, a Aprendizagem Situada dá elementos que melhor subsidiam o caráter pontual da visita ao museu na vida de uma pessoa, bem como a complexidade das relações socioculturais presentes em um museu de ciências.

Com base nesses referenciais, novas questões de pesquisa podem ser traçadas. Uma delas, por exemplo, é a investigação de quais ações de aprendizagem (que promovem a ascensão do abstrato ao concreto) são mais características dos museus de ciências. Como observado, as ações propostas por Davidov foram levantadas especificamente a partir do contexto escolar e 
as propostas por Engeström, do ambiente de trabalho profissional. É possível que a organização temporal e espacial, bem como a especificidade do objeto museal, (três elementos colocados por Van-Praët como centrais aos museus), representem regras fundamentais presentes em uma atividade de ensino/aprendizagem que influenciariam as ações dessa atividade desenvolvidas nesses ambientes. Assim, valeria ainda olhar para os instrumentos mediadores utilizados na organização do discurso expositivo pois, como visto, essa organização determinaria a forma como os sujeitos se apropriariam dos conceitos e práticas abordados.

A ênfase da perspectiva histórico-cultural no social e coletivo traz ainda outras questões de análise. Como proposto por Rubtsov (1996), o estudo da influência do fator cooperação sobre o processo de formação da atividade de aprendizagem pode se constituir como uma ferramenta importante para o entendimento do desenvolvimento psíquico. Para o autor, a repartição dos modos de ação e a troca dos modelos apropriados pelos sujeitos são passos fundamentais para o surgimento de novos processos cognitivos. Compreender quais as formas de organização da atividade em comum que mais contribuem para a aquisição de modos de interação entre os sujeitos também se constitui como um objeto de estudo relevante.

Em outro nível de análise, esses referenciais fornecem ainda subsídios para investigações interessadas no diálogo entre diferentes referenciais teóricos. Podem ser aproximados, por exemplo, dos referenciais que alertam para a necessidade de investigação da prática pedagógica em que fatores de larga escala integram-se a microníveis de análise, como ocorre nos campos recontextualizadores de Bernstein (1996). Esse autor propõe-se a explicar como os textos educacionais são organizados e como são construídos, colocados em circulação, contextualizados, apreendidos e modificados. Ao se considerar o museu como um campo recontextualizador pedagógico que, ao se preocupar com a práxis que regula a circulação de teorias e textos, acaba por gerar um discurso pedagógico próprio, e que essa recontextualização refere-se à prática educativa enquanto contexto pelo qual se dá a produção e a re-produção cultural, novas questões são postas na interface desses referenciais. Dessa forma, entender a recontextualização das exposições e dos materiais didáticos, por exemplo, ou compreender como a relação entre o setor educativo e as diferentes estâncias sociais (p. e., agências de fomento, políticas públicas, atores comunitários) influencia o discurso expositivo, constituem-se importantes elementos para o entendimento da atividade de ensino/aprendizagem em museus enquanto prática social sistêmica.

Com essas múltiplas camadas de análise e possibilidades de diálogo com outras 
teorias, a perspectiva histórico-cultural oferece boas possibilidades de entender o papel educativo dos museus de forma ampla, não somente como restrito ao processo de extroversão do patrimônio, mas também como presente em todos os elementos constitutivos da cadeia operatória museal. Possibilita a inserção do olhar educativo em diferentes aspectos, incluindo a seleção, a conservação, a extroversão dos acervos. A perspectiva histórico-cultural sugere, assim, um olhar diferenciado para a relação entre a sociedade e os artefatos mediadores da cultura, ressaltando o papel social das instituições museais pela ressignificação do patrimônio. 
Referências 



\section{REFERÊNCIAS}

ALLEN, S. Sociocultural theory in museums: insights and suggestions. Journal of Museum Education, Washington, vol. 22, n. 2/3, p. 8-9. 1997a.

ALLEN, S. Using scientific inquiry activities in exhibit explanations. Science Education, New York, vol. 81, n. 6, p. 715-720, Nov.1997b.

ALLEN, S. Looking for Learning in Visitor Talk: A Methodological Exploration. In: LEINHARDT, G.; CROWLEY, K.; KNUTSON, K. (eds.). Learning Conversations in Museums. Mahwah: Lawrence Erlbaum, 2002. p. 259-303.

ALLEN, S. Designs for Learning: Studying Science Museum Exhibits That Do More Than Entertain. Science Education, New York, vol. 88, n. S1, p. S17-S33, July 2004.

ANDERSON, D.; LUCAS, K.; GINNS, I. Theoretical perspectives on learning in an informal setting. Journal of Research in Science Teaching, Reston, vol. 40, n. 2, p. 177-199, Feb. 2003.

ALLARD, M.; BOUCHER, S. Éduquer au musée. Un modèle théorique de pédagogie muséale. Montréal: Éditions Hurtubise HMH Ltée, 1998. 207 p.

ALFONSO-GOLDFARB, A. M.; FERRAZ, M. Raízes históricas da difícil equação institucional da ciência no Brasil. São Paulo em Perspectiva, São Paulo, v. 16, n. 3, p. 3-14, jul/set. 2002.

ALMEIDA, A. M. A relação do público com o museu do Instituto Butantan: análise da exposição "Na natureza não existem vilões". 1995. 215 f. Dissertação (Mestrado em Comunicação) - Escola de Comunicação e Artes, Universidade de São Paulo, São Paulo, 1995.

ALMEIDA, M. Perspectivas sanitárias e representações médicas nos congressos médicos latinoamericanos (1901-1913). Horizontes, Bragança Paulista, v. 21, p. 37-47, jan/dez. 2003.

ALVES, A. O Ipiranga apropriado: ciência, política e poder, o Museu Paulista 1893-1922. São Paulo: Humanitas/FFLCH/USP, 2001. 213 p. 
ARAÚJO, M.; BRUNO, M. C. A memória do pensamento museológico contemporâneo: Documentos e Depoimentos. São Paulo: ICOM/Comitê Brasileiro, 1995. 45 p.

ANICO, M. A pós-modernização da cultura: património e museus na contemporaneidade. Horizontes Antropológicos, Porto Alegre, ano 11, n. 23, p. 71-86, jan./jun. 2005.

ASH, D. 2003. Dialogic inquiry in life science conversations of family groups in a museum. Journal of Research in Science Teaching, Reston, vol. 40, n. 2, p. 138-162, Feb. 2003.

ASH, D.; LEVITT, K. Working in the zone of proximal development: formative assessment as professional development. Journal of Science Teacher Education, Pittsburgh, vol. 14, n. 1, p. 23-48, Feb. 2003.

ASH, D.; WELLS, G. Dialogic Inquiry in Classroom and Museum: Actions, Tools, and Talk. In: BEKERMAN, Z.; BURBULES, N.; SILBERMAN-KELLER, D. Learning in places the informal education reader. New York: Peter Lang Publishing, 2006. p. 35-54.

BANNON, L. Activity Theory. 1997. Disponível em: <http://wwwsv.cict.fr/cotcos/pjs/ TheoreticalApproaches/Actvity/ActivitypaperBannon.htm. Acesso em 21 jul. 2005.

BAUDRILLARD, J. Simulacros e simulação. Lisboa: Relógio d'Água, 1991. 201p.

BENCHIMOL, J.; TEIXEIRA, L. Cobras, lagartos \& outros bichos - Uma história comparada dos institutos Oswaldo Cruz e Butantan. Rio de Janeiro: Editora UFRJ, 1993. 228 p.

BENNETT, T. The Birth of the Museum - history, theory, politics. Londres: Routledge, 1995. $288 \mathrm{p}$.

BENNETT, J. Can science museums take history seriously? In: MACDONALD, S. The Politics of Display - Museums, Science, Culture. Londres: Routledge, 1998. p. 173-182.

BERNSTEIN, B. A Estruturação do Discurso Pedagógico - classe, códigos e controle. Petrópolis: Editora Vozes, 1996.

BERTOLLI FILHO, C. A construção midiática na da biografia na era Vargas: Vital Brazil na Rádio Nacional. Cadernos de História da Ciência - Instituto Butantan, São Paulo, vol. 1, n. 2, p. 9-45, jul./dez. 2005 
BIZERRA, A.; ISZLAJI, C.; MEIRELES, F.; SCHUNCK, A.; CIZAUSKAS, I. A interação entre o público e as exposições do Museu Biológico do Instituto Butantan. In: Encontro Nacional de Pesquisa em Educação em Ciências (ENPEC), 6, 2007, Florianópolis. Anais do VI ENPEC, ABRAPEC, 2008a.

BIZERRA, A.; INGLEZ, G.; TINO DE FRANCO, M. The science museum explainers and their upbringing. In: REUNIÃO CIENTÍFICA ANUAL DO INSTITUTO BUTANTAN, 10, 2008, São Paulo. Anais Eletrônicos da X RECAIB. São Paulo: Instituto Butantan, 2008b.

BOISVERT, D.; SLEZ, B. The Relationship between Visitor Characteristics and LearningAssociated Behaviors in a Science Museum Discovery Space. Science Education, New York, vol. 78, n. 2, p. 137-148, Apr. 1994.

BOISVERT, D.; SLEZ, B. The Relationship between Exhibit Characteristics and LearningAssociated Behaviors in a Science Museum Discovery Space. Science Education, New York, vol. 79, n. 5, p. 503-518, Sept. 1995.

BORUN, M. Object-Based Learning and Family Groups. In: PARIS, S. (Ed.). Perspectives on object-centered learning in museums. London: Lawrence Erlbaum Associates, 2002. p. 245-260.

BORUN, M.; CHAMBERS, M.; CLEGHORN, A. Families are learning in science museums. Curator, Lanham, vol. 39, n. 2, p. 124 - 138, June 1996.

BRAZIL, V. Memória Histórica do Instituto Butantan. São Paulo: Elvino Pocai, 1941.170 p.

BROOKE, H.; SOLOMON, J. Passive visitors or independent explorers: Responses of pupils with severe learning difficulties at an Interactive Science Centre. International Journal of Science Education, vol. 23, n. 9, p. 941-953. 2001.

BROWN, C. Making the most of family visits: some observations of parents with children in a museum science centre. Museum Management and Curatorship, vol. 14, n. 1, p. 65-71, Mar. 1995.

BRUNO, M. C. Entre a Museologia e a Museografia: propostas, problemas e tensões. In: SEMINÁRIO INTERNACIONAL - História Representada: o dilema dos museus, 2002, Rio de Janeiro. Mesa-redonda. Disponível em: http://www.museologiaportugal.net/Mestrado_Museologia_2008/cristinab.htm\#Textos incluídos. Acesso em: 25 mar. 2008. 
CAMARgo, A. M. F. Os Impasses da Pesquisa Microbiológica e as Políticas de Saúde Pública em São Paulo (1892-1934). 1984. 233 f. Dissertação (Mestrado em Educação) Faculdade de Educação, Universidade Estadual de Campinas, Campinas, 1984.

CARVALHO, A. O Uso do vídeo na tomada de dados: pesquisando o desenvolvimento do ensino em sala de aula. Pro-Posições, Campinas, v. 7, n. 1, p. 5-13, mar. 1996.

CAZELLI, S., MARANDINO, M.; STUDART, D. Educação e Comunicação em Museus de Ciências: aspectos históricos, pesquisa e prática. In: GOUVÊA, G.; MARANDINO, M.; LEAL, M. C. (orgs.). Educação e Museus: A Construção Social do Caráter Educativo dos Museus de Ciências. Rio de Janeiro: FAPERJ/Access Editora. 2003. p. 83-106.

CEDRO, W. O espaço de aprendizagem e a atividade de ensino: o clube de matemática. 2004. 171f. Dissertação (Mestrado em Educação) - Faculdade de Educação, Universidade de São Paulo, São Paulo, 2004.

CEDRO, W. O motivo e a atividade de aprendizagem do professor de Matemática: uma perspectiva histórico-cultural. 2008. 242 fls. Tese (Doutorado em Educação) - Faculdade de Educação, Universidade de São Paulo. 2008.

CHAPIN, D., KLEIN, S. Forum: the Epistemic Museum. Museum News, Washington, 71, v. 4, July/Aug., 60-1. 1992.

CROWLEY, K; CALLANAN, M.; JIPSON, J.; GALCO, J.; TOPPING, K.; SHRAGER, J. Shared Scientific Thinking in Everyday Parent-Child Activity. Science Education, New York, vol. 85 , n. 6, p. 712-32, Nov. 2001a.

CROWlEY, K.; CALlANAN, M.; TENENBAUM, H.; ALLEN, E. Parents explain more often to boys than to girls during shared scientific thinking. Psychological Science, Washington, vol. 12, n. 3, p. 258-261, May 2001b.

CSIKSZENTMIHALYI, M., \& HERMANSON, K. Intrinsic motivation in museums: What makes visitors want to learn? Museum News, Washington, vol. 74, n. 3, p. 34-37, May/June 1995.

DANIELS, H. Vygotsky e a Pedagogia. São Paulo: Edições Loyola, 2003. 246 p.

DAVÍDOV, V. Tipos de generalización en la enseñanza. Havana: Editorial Pueblo y Educacion, 1982. 488p. 
DAVIDOV, V. La enseñanza escolar y el desarrollo psiquico: investigación psicológica teórica y experimental. Moscou: Editorial Progreso, 1988. 280p.

DAVÍDOV, V.; MÁRKOVA, A. La concepción de la actividad de estudio de los escolares. In: La psicologia evolutiva e pedagógica en la URSS. Moscou: Editorial Progreso, 1987. p. 316337.

DAVYDOV, V. Problems of developmental teaching: The experience of theoretical and experimental psychological research. Excerpts (Part 1). Soviet Education, Armonk, v. 30, n. 8, p. 6-110, Aug. 1988a.

Problems of developmental teaching: The experience of theoretical and experimental psychological research. Excerpts (Part 2). Soviet Education, Armonk, v. 30, n. 9, p. 3-83, Sept. 1988b.

What is a real learning activity? In: HEDEGAARD, M.; LOMPSCHER, J. Learning Activity and Development. Aarhus: Aarhus University Press, 1999a. p. 123-138.

The content and unsolved problems of activity theory. In: ENGESTRÖM, Y., MIETTINEN, R., PUNAMÄKI, R. (Eds.). Perspectives on activity theory. New York: Cambridge University Press, 1999b. p. 39-52.

A new approach to the interpretation of activity structure and content. In S. CHAIKLIN, S.; HEDEGAARD, M.; JENSEN, U. (Eds.) Activity theory and social practice. Aarhus: Aarhus University Press, 1999c. p. 39-50.

DAVYDOV, V.; MARKOVA, A. A concept of educational activity for school children. Soviet Psychology, v. 21, n. 2, p. 50-76, 1983.

DERBY, O. A. The present state of science in Brazil. Science, v. 1, n. 8, p. 211-214, mar. 1883.

DESVALLÉES, A. Cent quarante termes muséologiques ou petit glossarie de l'exposition. In: BARY, M. \& TOBELEM, J. (dir.), Manuel de Muséographie: petit guide à l'usage des responsables de musée. 2000.

DIAMOND, J. Practical Evaluation Guide: Tools for Museums and Other Informal Educational Settings. Walnut Creek: Altamira Press. 1999. 192 p. 
ELLENBOGEN, K. M.; LUKE, J. J.; DIERKING, L. D. Family Learning Research in Museums: An emerging Disciplinary Matrix? Science Education, New York, vol. 88, n. S1, p. S48-S58, July 2004.

ENGESTRÖM, Y. Learning by Expanding: An Activity - Theoretical Approach to Developmental Research. Helsinki: Orienta-Konsultit Oy, 1987.

Disponível em:

http://communication.ucsd.edu/LCHC/MCA/Paper/Engestrom/expanding/toc.htm> Acesso em 15 fev. 2008.

ENGESTRÖM, Y. Activity theory and individual and social transformation. In: ENGESTRÖM, Y., MIETTINEN, R., PUNAMÄKI, R. (Eds.). Perspectives on activity theory. New York: Cambridge University Press, 1999a. p 19-38.

ENGESTRÖM, Y. Innovative learning in work teams: Analyzing cycles of knowledge creation in practice. In: ENGESTRÖM, Y., MIETTINEN, R., PUNAMÄKI, R. (Eds.). Perspectives on activity theory. New York: Cambridge University Press, 1999b. p 377-406.

ENGESTRÖM, Y. Expansive Learning at Work: toward an activity theoretical reconceptualization.

Journal of Education and Work, v. 14, n. 1, p. 133-156, 2001.

ENGESTRÖM, Y.; MIETTINEN, R. Introduction. In: theory. New York: Cambridge University Press, 1999. p 1-18.

Perspectives on activity

FALCÃO, D. Padrões de interação e aprendizagem em museus de ciências. 1999. Dissertação (Mestrado em Bioquímica) - Universidade Federal do Rio de Janeiro, 1999.

FALCÃO, D.; ALVES, F.; KRAPAS, S.; COLINVAUX, D. Museus de Ciências, Aprendizagem e Modelos Mentais: Identificando Relações. In: GOUVÊA, G.; MARANDINO, M.; LEAL, M. (orgs.). Educação e Museus: A Construção Social do Caráter Educativo dos Museus de Ciências. Rio de Janeiro: FAPERJ/Access Editora. 2003. p.185206.

FALK, J. Free-Choice Science Learning: Framing the Discussion. In: Free-Choice Science Education: How We Learn Science Outside of School. New York: Teachers College, Columbia University. 2001. p. 3-20. museums. London: Lawrence Erlbaum Associates, 2002. p. ix-xiii. 
FALK, J. The Director's Cut: Toward an Improved Understanding of Learning from Museums. Science Education, New York, vol. 88, n. S1, p. S83-S96, July 2004.

FALK, J.; ADELMAN, L. Investigating the impact of prior knowledge and interest on aquarium visitor learning. Journal of Research in Science Teaching, Reston, vol. 40, n. 2, p. 163-176, Feb. 2003.

FALK, J.; DIERKING, L. The Museum Experience. Washington: Whalesback Books. 1992. $206 \mathrm{p}$.

School Field Trips: Assessing Long-Term Impact. Curator, Lanham, vol. 40, n. 3, p. 211-218, Sept. 1997.

Learning from Museums: Visitors Experiences and the Making of Meaning. Walnut Creek: Altamira Press. 2000. 272 p.

FALK, J.; MOUSSOURI, T.; COULSON, D. The Effect of Visitors' Agendas on Museum Learning. Curator, Lanham, vol. 41, n. 2, p. 106-120, June 1998.

FALK, J.; SCOTT, C.; DIERKING, L.; RENNIE, L.; JONES, M. Interactives and Visitor Learning. Curator, Lanham, vol. 47, n. 2, p. 171-198, Apr. 2004.

FALK, J.; STORKSDIECK, M. Learning science from museums. História, Ciências e Saúde, Rio de Janeiro, vol. 12 (supl.), p.117-143, Jan. 2005a.

. Using the contextual model of learning to understand visitor learning from a science center exhibition. Science Education, New York, vol. 89, n. 5, p. 744-778, sep. 2005 b.

FAYARD, P. La sorpresa de Copérnico: el conocimiento gira alrededor del público. Alambique -Didáctica de las Ciencias Experimentales, n. 21, p. 9-16, jul/sept. 1999.

FIGUEIRÔA, S. F. M. Associativismo científico no Brasil: o Instituto Histórico e Geográfico Brasileiro como espaço institucional para as Ciências Naturais durante o século XIX. Interciencia, Caracas, vol. 17, n. 3, p. 141-146, mayo/jun. 1992.

FILGUEIRAS, C. A. L. A Química no Brasil de Hoje. Química Nova, São Paulo, v. 22, n. 1, p. 147-152, jan/fev. 1999. 
FONSECA, F. Instituto Butantã: sua origem, desenvolvimento e contribuição ao progresso de São Paulo. In: São Paulo em quatro séculos. São Paulo, Comissão do IV Centenário de São Paulo, v. 2, 1954. p. 269-319.

FONSECA, M. As 'Conferências Populares da Glória': a divulgação do saber científico. História, Ciências, Saúde - Manguinhos, Rio de Janeiro, v. 2, n. 3, nov/fev. 1996.

FORS, V. Science centre exhibits - from a teenager's point of view. 12p. 2004. Disponível em: <http://www.ltu.se/polopoly_fs/1.2943!51efbdce.pdf>. Acesso em: 04 mai. 2008.

FUNDAÇÃO OSWALDO CRUZ. Almanaque histórico: Oswaldo Cruz o médico do Brasil. Rio de Janeiro: ODEBRECHT; Fundação Banco do Brasil, 2003. 60 p.

GAMMON, B. Assessing learning in museum environments: A practical guide for museum evaluators. London, Science Museum, unpublished report. 2001. Disponível em: $<\mathrm{http}: / / \mathrm{www}$. ecsiteuk.net/events/reports/indicators_learning_1103_gammon.pdf>. Acesso em: 04 mai. 2008.

GARCIA, V. O Processo de ensino-aprendizagem no Zôo de Sorocaba: análise da atividade de educativa visita orientada a partir dos objetos biológicos. 2006. 224 fls. Dissertação (Mestrado em Educação) - Faculdade de Educação, Universidade de São Paulo, 2006.

GARNIER, C.; BEDNARZ, N.; ULANOVSKAYA, I. A aprendizagem como atividade coletiva: escolha e organização das atividades segundo as correntes soviética e sócioconstrutivista. In: In: GARNIER, C.; BEDNARZ, N.; ULANOVSKAYA, I. (org.). Após Vygotsky e Piaget: perspectivas social e construtivista - escolas russa e ocidental. Porto Alegre: Artes Médicas, 1996. p. 207-222.

GASPAR, A. Museus e Centros de Ciências: conceituação e proposta de um referencial teórico. 1993. 173 fls. Tese (Doutorado em Educação) - Faculdade de Educação, Universidade de São Paulo, 1993.

GASPAR, A.; HAMBURGER, E. Museus e Centros de Ciências. In: NARDI, R. (org.) Pesquisas em Ensino de Física. São Paulo: Escrituras Editora, 1998. p. 105-125.

GILBERT, J.; PRIEST, M. Models and Discourse: A Primary School Science Class Visit to a Museum. Science Education, New York, vol. 81, n. 6, p. 749-762, Nov. 1997. 
GIORDAN, M. Uma perspectiva sociocultural para os estudos sobre elaboração de significados em situações de uso do computador na Educação em Ciências. 2006. 319fls. Tese (Livre-Docência em Educação) - Faculdade de Educação, Universidade de São Paulo, 2006.

GONZÁLEZ REY, F.. El lugar de las emociones en la constitución social de lo psíquico: el aporte de Vigotski. Educ. Soc., Campinas, v. 21, n. 71, July 2000. Disponível em $<$ http://www.scielo.br/scielo.php?script=sci_arttext\&pid=S0101-

$73302000000200006 \& \operatorname{lng}=$ en\&nrm=iso >. Acesso em 25 mar. 2009.

GRIFFIN, J. Research on Students and Museums: Looking More Closely at the Students in School Groups. Science Education, New York, vol. 88, n. S1, p. S59-S70, July 2004.

HEDEGAARD, M. A zona de desenvolvimento proximal como base para o ensino. In: DANIELS, H. (org.) Uma introdução a Vygotsky. São Paulo: Edições Loyola, 1996. p. 199228.

HEIN, G. Learning in the Museum. Londres: Routledge, 1998. 216 p.

HOOPER-GREENHILL, E. Education, communication and interpretation: towards a critical pedagogy in museums. In: The Educational Role of the Museum. 2nd ed. Londres:

Routledge. 1999a. p. 3-27.

Communication in theory and practice. In: : HOOPER-GREENHILL, E. The Educational Role of the Museum. 2nd ed. Londres: Routledge. 1999b. p. 28-43.

Museum learners as active post-modernists: contextualizing constructivism. In: HOOPER-GREENHILL, E. The Educational Role of the Museum. 2nd ed. Londres: Routledge. 1999c. p. 67-72.

INSULANDER, E. Museus and learning: a research overview. 2005. Disponível em: <http://www.didaktikdesign.nu/dok_dd/museer_larande_eng.pdf. Acesso em 15 mar. 2008.

JEFFERY-CLAY, K. Constructivism in Museums: How Museums Create Meaningful Learning Environments. Journal of Museum Education, Washington, vol. 23, n. 1, p. 3-7. 1998.

KELLY, L. Understanding Museum Learning from the Visitor's Perspective. Curator, Lanham, vol. 46, n. 4, p. 362-366, Oct. 2003. 
KIESTER, R. Aesthetics of Biological Diversity. Human Ecology Review, Bar Harbor, v.3, n. 2, p. 151-157, Dec.1996.

KORN, R. An Analysis of Differences Between Visitors at Natural History Museums and Science Centers. Curator, Lanham, vol. 38, n. 3, p. 150-160, Sept. 1995.

KOZULIN, A. The concept of activity in soviet psychology - Vygotsky, his disciples and critics. American Psychologist, Washington, v. 41. n. 3, p. 264-274, Mar. 1986.

LANNER DE MOURA, A. Memorial: fazendo-me professora. Cad. CEDES [on line], v.19, n. 45, p. 24-47. jul. 1998. Disponível em: http://www.scielo.br/scielo.php?pid=S010132621998000200003\&script=sci_arttext\&tlng=es> Acesso em: 21 mar. 2009.

LAVE, J. Cognition in Practice: Mind, mathematics, and culture in everyday life. Cambridge: Cambridge University Press, 1988. 232 p.

LAVE, J; WENGER, E. Situated Learning: Legitimate Peripheral Participation. Cambridge: Cambridge University Press, 1991. 138 p.

LAVE, J.; WENGER, E. Prática, pessoa, mundo social. In: DANIELS, H. (org.) Uma introdução a Vygotsky. São Paulo: Edições Loyola, 1996. 364p.

LEFEBVRE, H. Lógica formal, lógica dialética. Rio de Janeiro: Civilização Brasileira, 1987.

LEINHARDT, G.; CROWLEY, K. Objects of Learning, Objects of Talk: Changing Minds in Museums. In: PARIS, S. (Ed.). Perspectives on object-centered learning in museums. London: Lawrence Erlbaum Associates, 2002. p. 301-324.

LEINHARDT, G.; KNUSTON, K.; CROWLEY, K. Museum Learning Collaborative Redux. Journal of Museum Education, Washington, vol. 28, n. 1, 2003. p. 23-31.

LEONT'EV, A. Activity, Consciousness, and Personality. New Jersey: Prentice-Hall, 1978. 186p. Disponível em: <http://www.marxists.org/archive/leontev/works/1978/ch3.htm> Acesso em 12 mai. 2008.

LEONTIEV, A. O desenvolvimento do psiquismo. 2. ed. São Paulo: Centauro Editora, 2004. $350 \mathrm{p}$. 
LEWENSTEIN, B. Models of Public Communication of Science and Technology. Version 16, June 2003.11p.Disponível em: <http://communityrisks.cornell.edu/BackgroundMaterials/ Lewenstein2003.pdf>. Acesso em: 04 abr. 2008.

LIBÂNEO, J. A didática e a aprendizagem do pensar e do aprender: a teoria histórico-cultural da atividade e a contribuição de Vasili Davydov. Revista Brasileira de Educação, Rio de Janeiro, v. 27, n. 27, p. 5-24, 2004.

LIMA, E. Desenvolvimento e Aprendizagem na Escola: Aspectos Culturais, Neurológicos e Psicológicos. São Paulo: Série "Separatas" - Grupo de Estudos do Desenvolvimento Humano (GEDH). 1997.

LOMPSCHER, J.; HEDEGAARD, M. Introduction. In: HEDEGAARD, M.; LOMPSCHER, J. Learning Activity and Development. Aarhus: Aarhus University Press, 1999. p. 10-21.

LOPES, M. O Brasil descobre a pesquisa científica: os museus e as ciências naturais no século XIX. São Paulo: Hucitec, 1997. 369 p.

LOTMAN, Y. Text within a text. Tradução em inglês: Jerry Leo and Amy Mandelker Publications of the Modern Language Association, New York, v. 109, n. 3, p. 377-384, May 1994.

LUPTON, E.; PHILLIPS, J. Novos Fundamentos do Design. São Paulo: CosacNaify, 2008. 248p.

MACDONALD, S. The Politics of Display: Museums, Science, Culture. London: Routledge, 1998. 264p.

MALET, A. Divulgación y popularización científica em el siglo XVIII: entre la apología cristiana y La propaganda ilustrada. Quark - Ciencia, Medicina, Comunicación y Cultura, Barcelona, v. 26, oct/dic. 2002.

MARANDINO, M. O Conhecimento Biológico nas Exposições de Museus de Ciências: análise do processo de construção do discurso expositivo. 2001, 434 fls. Tese (Doutorado em Educação) - Faculdade de Educação, Universidade de São Paulo. 2001.

MARANDINO, M. É possível estudar aprendizagem nos museus de Ciências? In: NARDI, R. (org.). A pesquisa em ensino de ciências no Brasil: alguns recortes. São Paulo: Escrituras Editora, 2007. p. 41-50. 
MARANDINO, M. Ação educativa, aprendizagem e mediação nas visitas aos museus de ciências. In: MASSARANI, L. (Ed.). Workshop Sul-Americano \& Escola de Mediação em Museus e Centros Ciência. Rio de Janeiro: Museu da Vida / Casa de Oswaldo Cruz / Fiocruz, 2008. p. 21-28.

MARANDINO, M.; SILVEIRA, R.; GARCIA, V.; LOURENÇO, M.; FLORENTINO, H. A Educação Não Formal e a Divulgação Científica: O que pensa quem faz? In: Encontro Nacional de Pesquisa em Ensino de Ciência, 4, 2003, Bauru. Livro de Resumos - IV ENPEC. Bauru: ABRAPEC, 2003.

MARANDINO, M.; BIZERRA, A.; NAVAS, A. M.; FARES, D.; STANDERSKI, L.; MONACO, L.; MARTINS, L.; SOUZA, M. P.; GARCIA, V. Educação em museus: a mediação em foco. São Paulo: GEENF/FEUSP. 2008. p. 36.

MARQUES, O.; PUORTO, G. Padrões cromáticos, distribuição e mimetismo de Erythrolamprus aesculapii (Serpentes, Colubridae). Memórias do Instituto Butantan, São Paulo, v. 53, p. 127-134, 1991.

MARTIN, L. An Emerging Research Framework for Studying Informal Learning and Schools. Science Education, New York, vol. 88, n. S1, p. S71-S82, July 2004.

MARTINS, L. A relação museu/escola: teoria e prática educacionais nas visitas escolares ao Museu de Zoologia da USP. 2006. 237f. Dissertação (Mestrado em Educação) - Faculdade de Educação, Universidade de São Paulo, São Paulo, 2006.

MASSARANI, L. A Divulgação Científica no Rio de Janeiro: Algumas Reflexões sobre a Década de 20. 1998. 177 f. Dissertação (Mestrado em Ciência da Informação) - Instituto Brasileiro de Informação em C\&T-IBICT e Escola de Comunicação, Universidade Federal do Rio de Janeiro, Rio de Janeiro, 1998.

MASSARANI, L.; MOREIRA, I. C. Divulgación de la Ciencia: Perspectivas Históricas y Dilemas Permanentes. Quark - Ciência, Medicina, Comunicación y Cultura, Barcelona, v. 32, p. 30-35, abr/jun. 2004.

MATUSOV, E. When Solo Activity Is Not Privileged: Participation and Internalization Models of Development. Human Development, v. 41, n. 5/6, p. 326-349, Sept./Dec. 1998.

MATUSOV, E; ROGOFF, B. Evidence of development from people's participation in communities of learners. In: FALK, J. (Ed.). Public institutions for personal learning: Understanding the long-term impact of museums. Washington: American Association of Museums, $1995 . \quad$ p. $97-104 . \quad$ Disponível em: http://ematusov.soe.udel.edu/vita/publications.htm. Acesso em 26 mar. 2006. 
MCMANUS, P. Good companions: More on the social determination of learning-related behaviour in a science museum. Museum Management and Curatorship, vol. 7, n. 1, p. 3744, Jan. 1988.

MCMANUS, P. Topics in Museums and Science Education. Studies in Science Education, Leeds, vol. 20, n. 1, p. 157-182. 1992.

MICHENER, D.; SCHULTZ, I. Through the Garden Gate: Objects and Informal Education for Environmental and Cultural Awareness in Arboreta and Botanic Gardens. In: PARIS, S. (Ed.). Perspectives on object-centered learning in museums. London: Lawrence Erlbaum Associates, 2002. p.95-112.

MIGUEIS, M; MOURA. M.; PORTUGAL, G.. A aprendizagem docente. Contribuições da Psicologia Histórico-cultural. In: Congresso Internacional do CIDInE: Novos contextos de formação, pesquisa, mediação, 2., 2009, Vila Nova de Gaia. Anais eletrônicos. Vila Nova de Gaia: CIDInE, 2009. Disponível em: <http://www.ispgaya.pt/cidine/ cidine2009/ PAPERCIDINE/P_MIGUEIS, MOURA\&PORTUGAL.pdf> Acesso em 25 abr. 2009.

MOREIRA, I; MASSARANI, L. Aspectos Históricos da Divulgação Científica no Brasil. In: Ciência e Público: caminhos da divulgação científica no Brasil. Rio de Janeiro: Casa da Ciência, UFRJ, Rio de Janeiro. 2002. p. 43-64.

MOURA, M. A atividade de ensino como unidade formadora. Bolema, São Paulo, v. 2, n.12, p. 29-43, 1996.

A atividade de ensino como ação formadora. In: CASTRO, A.; CARVALHO, A. Ensinar a ensinar: didática para a escola. São Paulo: Pioneira - Thompson Learning, 2001. p. 143-162.

O educador na coletividade de formação. In: TIBALLI, E.; CHAVES, S. Concepções e práticas em formação de professores - diferentes olhares. Rio de Janeiro: DP\&A, 2003. p. 129-145.

MINUCHIN, S. Famílias: Funcionamento e Tratamento. Porto Alegre: Artes Médicas, 1990. $240 \mathrm{p}$.

NAGAMINI, M. 1808-1889: Ciência e técnica na trilha da liberdade. In: MOTOYAMA, S. (org.); NAGAMINI, M.; QUEIROZ, F. A.; VARGAS, M. (col.) Prelúdio para uma História: Ciência e Tecnologia no Brasil. São Paulo: EDUSP, 2004a. p. 135-183. 
NAGAMINI, M. 1889-1930: Ciência e tecnologia nos processos de industrialização e urbanização. In: MOTOYAMA, S. (org.); NAGAMINI, M.; QUEIROZ, F. A.; VARGAS, M. (col.) Prelúdio para uma História: Ciência e Tecnologia no Brasil. São Paulo: EDUSP, 2004b. p. 185-231.

NASCIMENTO, S. A linguagem e a investigação em Educação Científica: uma breve apresentação. In: NARDI, R. (org.). A pesquisa em ensino de ciências no Brasil: alguns recortes. São Paulo: Escrituras Editora, 2007. p. 131-142.

NOSTI, M. ¿Cuál es la Situación de los Servicios Educativos? In: ENCONTRO REGIONAL DA AMÉRICA LATINA E CARIBE - CECA/ICOM, 4., 2005, São Paulo, Palestras. São Paulo: FAAP/CECA/ICOM, p. 20-29.

OLIVEIRA, M. K. Três questões sobre o desenvolvimento conceitual. In: OLIVEIRA, M. B; OLIVEIRA, M. K. Investigações Cognitivas: Conceitos, Linguagem e Cultura. Porto Alegre: Artes Médicas, 1999. p. 55-64.

OLIVEIRA, M. K. História, consciência e educação. In: PINTO, M. (Ed.). Lev Seminovich Vygotsky. Coleção memória da pedagogia, v. 2. São Paulo: Segmento-Dutto, 2005. p. 6-13.

OLIVEIRA, M. K. Vygotsky: aprendizado e desenvolvimento - um processo sócio-histórico. 4. ed. São Paulo: Scipione, 2006. 112p.

OSBERG, S. Shared Lessons and Self-Discoveries: What Research Has Taught Children's Discovery Museum. Journal of Museum Education, Washington, vol. 23, n. 1, p. 19-20. 1998.

OSBORNE, J. Constructivism in Museums: A Response. Journal of Museum Education, Washington, vol. 23, n. 1, p. 8-9. 1998.

PANZA, M.; PRESAS, A. La divulgación de la ciencia en el siglo XIX: la obra de Flammarion. Quark - Ciencia, Medicina, Comunicación y Cultura, Barcelona, v. 26, oct/dic. 2002.

PARIS, S. Perspectives on object-centered learning in museums. London: Lawrence Erlbaum Associates, 2002. 408p.

PARIS, S.; ASH, D. Reciprocal Theory Building Inside and Outside Museums. Curator, Lanham, vol. 43, n. 3, p. 199-210, July 2000. 
PEKARIK, A.; DOERING, Z.; KARNS, D. Exploring Satisfying Experiences in Museums. Curator, Lanham, vol. 42, n. 2, p. 152-173, Apr. 1999.

PINO, A. O Biológico e o Cultural nos Processos Cognitivos. In: MORTIMER, E. e SMOLKA, A. L. (orgs.) Linguagem, Cultura e Cognição: Reflexões para o ensino e a sala de aula. Belo Horizonte: Autêntica Editora, 2001. p. 21-50.

PINO, A. As marcas do humano - às origens da constituição cultural da criança na perspective de Lev. S. Vigotski. São Paulo: Cortez, 2005. 304p.

PUCHNER, L.; RAPOPORT, R.; GASKINS, S. Learning in Children's Museums: Is It Really Happening? Curator, Lanham, vol. 44, n. 3, p. 237-259, July 2001.

PUJOL, R. Educación Cintífica para la Cidadania en Formación. Alambique, n. 32, p. 09-16, 2002.

RAHM, J. Multiple modes of meaning-making in a science center. Science Education, New York, vol. 88, n. 2, p. 223-247, Mar. 2004.

RENNIE, L.; FEHER, E.; DIERKING, L.; FALK, J. Toward an agenda for advancing research on science learning in out-of-school settings. Journal of Research in Science Teaching, Reston, vol. 40, n. 2, p. 112-120, Feb. 2003.

RENNIE, L.; JOHNSTON, D. The Nature of Learning and Its Implications for Research on Learning from Museums. Science Education, New York, v. 88, n. S1, p. S4-S16, July 2004.

RIZZO, E. Homenagem. Rosa Pavone Pimont (1930-1983). Memórias do Instituto Butantan, São Paulo, v. 47/48, p. 1-2. 1983/1984.

ROBERTS, L. Educators on Exhibit Teams: a New Role, a New Era. Journal of Museum Education, Washington, vol. 19, n. 3, p. 6-9. 1994.

ROGERS, Y.; SCAIFE, M. Activity Theory. 1997. Disponível em: $<$ http://wwwsv.cict.fr/cotcos/pjs/TheoreticalApproaches/Actvity/ActivitypaperRogers.htm>. Acessado em2121/07/05. 
ROWE, S. The role of objects in active, distributed meaning-making. In: PARIS, S. (Ed.). Perspectives on object-centered learning in museums. London: Lawrence Erlbaum Associates, 2002. p.19-35.

RUBTSOV, V. A atividade de aprendizado e os problemas referentes à formação do pensamento teórico dos escolares. In: GARNIER, C.; BEDNARZ, N.; ULANOVSKAYA, I. (org.). Após Vygotsky e Piaget: perspectivas social e construtivista - escolas russa e ocidental. Porto Alegre: Artes Médicas, 1996. p. 129-137.

SAPIRAS, A. Aprendizagem em Museus: uma análise das visitas escolares no Museu Biológico do Instituto Butantan. 2007. 155 fls. Dissertação (Mestrado em Educação) Faculdade de Educação, Universidade de São Paulo. 2007.

SANTAELLA, L. Matrizes da Linguagem e do Pensamento - sonora visual verbal. 3. ed. São Paulo: Iluminuras: FAPESP, 2005. 432p.

SCHAUBLE, L.; GLEASON, M.; LEHRER, R. ; BARTLETT, K. ; PETROSINO, A. ; ALLEN, A.; CLINTON, K. ; HO, E. ; JONES, M. ; YEE, Y.-S. ; PHILLIPS, J.-E. ; SIEGLER, J. ; STREET, J. Supporting science learning in museums. In LEINHARDT, G.; CROWLEY, K.; KNUTSON, K. (eds.). Learning conversations in museums. Mahwah: Lawrence Erlbaum, 2002. p. 425-452.

SCHAUBLE, L.; LEINHARDT, G.; MARTIN, L. A framework for organizing a cumulative research agenda in informal learning contexts. Journal of Museum Education, Washington, vol. 22, n. 2/3, p. 3-8. 1997. Disponível em: <http://www.museumlearning.org/mlc_jme.pdf>. Acesso em: 07. mai. 2008.

SERRÃO, M. Estudantes de pedagogia e a "atividade de aprendizagem" do ensino em formação. 2004. Tese (Doutorado em Educação) - Faculdade de Educação, Universidade de São Paulo, 2004.

SERRELL, B. Paying Attention: The Duration and Allocation of Visitors' Time in Museum Exhibitions. Curator, Lanham, vol. 40, n. 2, p. 108-125, June 1997.

SFORNI, M. Aprendizagem Conceitual e Organização do Ensino: contribuições da teoria da atividade. Araraquara: Junqueira\&Marin Editores. 2004. 197 p.

SMITH, M. 2001. Non-formal education. Disponível em: <http://www.infed.org/biblio/bnonfor.htm\#idea>. Acesso em 15 ago. 2004. 
STOCKLMAYER, S.; GILBERT, J. New experiences and old knowledge: towards a model for the personal awareness of science and technology. International Journal of Science Education, vol. 24, n. 8, p. 835-858. 2002.

TRAN, L. Teaching Science in Museums: The Pedagogy and Goals of Museum Educators. Science Education, New York, vol. 91, n. 2, p. 278-297, Mar. 2007.

TUNNICLIFFE, S. Conversations of family and primary school groups at robotic dinosaur exhibits in a museum: what do they talk about. International Journal of Science Education, vol. 22 , n. 7, p. 739-754, 2000.

VALENTE, M. E. A Conquista do Caráter Público do Museu. In: GOUVÊA, G.; MARANDINO, M.; LEAL, M. C. (orgs.). Educação e Museu: a construção do caráter educativo dos museus de ciências. Rio de Janeiro: FAPERJ/Editora Access, 2003. p. 21-46.

VAN-PRAËT, M. Aspects of Learning in the Natural History Museum. Or, are all Visitors Disabled in Science? Art Bulletin of Nationalmuseum Stockholm, Stockholm, vol. 5, p. 131-136, 1998.

Les expositions scientifiques, "miroirs épistemologiques" de l'évolution des idées en sciences de la vie. Bulletin D'Histoire et D'Epistémologie des Sciences de La Vie, Paris, v. 2, n. 1, p. 52-69, 1995.

VAN-PRAËT, M.; POUCET, B Les Musées, Lieux de Contre-Éducation et de Partenariat avec l'École. Éducation \& Pédagogies, vol. 16, p. 21-29. 1992. Disponível em: $<\mathrm{http}: / / \mathrm{www}$.ac-grenoble.fr/patrimoineeducation/seminaire/contreduc_partena.htm $>$. Acesso em 12 mar. 2006.

VESSURI, H. M. C.; CAPEL, H. As Associações Científicas do Século XIX na América Latina. Interciencia, Caracas, v. 17, n. 3, p. 134, mayo/jun. 1992.

VIGOTSKI, L. A Construção do Pensamento e da Linguagem. São Paulo: WMF Martins Fontes, 2001. 496p.

VIGOTSKI, L. A formação social da mente. 7. ed. São Paulo: Martins Fontes, 2007.186p.

VYGOTSKY, L. Consciousness as a problem in the psychology of behavior. Soviet Psychology, vol. 17, n. 4, p. 3-35, 1979. Disponível em: <http://www.marxists.org/archive/ vygotsky/works/1925/consciousness.htm> Acesso em 15 fev. 2008. 
WAGENSBERG, J. A favor del conocimiento científico (los nuevos museos). ÉNDOXA: Series Filosóficas, Madrid, n. 14, p. 341-356. 2001.

WAITE, T. Activity Theory. 2003. Disponível em:

$<$ http://www.slis.indiana.edu/faculty/yrogers/act_theory2>. Acesso em 21 jul. 2005.

WENGER, E. Communities of Practice: Learning, Meaning, and Identity. Cambridge:

Cambridge University Press, 1999. 336 p.

ZOLCSAK, E.; VITIELLO, N.; FEDERSONI J, P.; BUONONATO, M. Análise do aprendizado do visitante do Museu do Instituto Butantan. Ciência e Cultura, São Paulo, vol. 40, n. 2, p. 190-193, 1988. 
Apêndices 



\section{APÊNDICE 1 - OUTRAS ESTRATÉGIAS EDUCACIONAIS E COMUNICACIONAIS DESENVOLVIDAS PELO INSTITUTO BUTANTAN DURANTE O SÉCULO XX.}

\section{Conferências públicas}

As palestras direcionadas ao público em geral sempre fizeram parte das ações de divulgação científica do Instituto Butantan. Já em 1902, foram oferecidas conferências posteriormente descritas por Vital Brazil ${ }^{1}$ :

Em dezembro de 1901 fiz a primeira conferencia sobre o ofidismo levada a efeito na Escola de Farmacia de São Paulo, que na epoca funcionava no palacete Marqueza de Santos no começo da rua Brigadeiro Tobias. Essa conferencia acompanhada de demonstrações experimentais, nas quais, pela primeira vez, demonstrei, em publico, a eficacia do tratamento especifico, teve grande assistencia de medicos, professores e representantes das autoridades e de varias classes sociais, conseguindo pela repercussão obtida interessar grande numero de pessoas na solução do problema. Outras conferencias seguiram-se sempre acompanhadas de demostrações praticas: extração de veneno e ação preventiva e curativa dos soros especificos (p. XII).

Nesse relato, é possível perceber algumas características relevantes da divulgação no Instituto por meio das conferências populares. Apesar de citar "varias classes sociais" como parte do público participante, atenção maior é dada na descrição do público-alvo dessas palestras: profissionais letrados que poderiam divulgar a importância dos novos estudos. Vale lembrar que os locais onde eram realizadas as conferências (como a Escola de Pharmacia ou a Escola Polythecnica de São Paulo) talvez não fossem os mais receptivos para a população em geral, predominantemente analfabeta. Vemos aqui que pode haver uma semelhança com as Conferências Populares da Glória, ou as similares, que embora tivessem intenção de atingir uma ampla audiência, acabavam por receber um público restrito. Infelizmente, não há muitos registros sobre as características da audiência das conferências públicas externas do Instituto Butantan. Vemos ainda a característica predominante da divulgação científica da época: o foco na ciência experimental. Eram realizados experimentos ao vivo, com manuseio de animais e estudos sobre os venenos. As "lições sobre serumtherapia", conhecimento altamente aplicado, estavam geralmente presentes nessas conferências.

Observamos ainda a ocorrência de conferências ministradas no próprio Instituto, que aparecem já nos primeiros relatórios anuais. Em 1913, passaram a ser oferecidas em dias específicos, "fixadas para a primeira quinta-feira de cada mes, ás duas horas da tarde"2. A primeira dessas conferências planejadas versou sobre história natural de serpentes e a segunda, sobre "o

Brazil, V. Recordando... In: Memórias do Instituto Butantan, 14:IX-XII. 1940.

Relatório Anual de 1913. 
estudo das differentes peçonhas; sua extracção, acção toxicologica etc. [sendo] bêm concurrida".

Provavelmente, essas atividades tiveram grande êxito, pois, no primeiro edifício construído especificamente para o Instituto Butantan, inaugurado em 1914, havia uma sala destinada especialmente a conferências e demonstrações, batizada de "Sala Prof. Robert Koch"3. Gradualmente, as conferências deixaram de ser pontuadas nos relatórios anuais de forma clara (com título e palestrante), como atividades da instituição. Passaram a ser descritas de forma geral e, principalmente, com referências indiretas, como no Relatório de 1919, no qual é descrito o mobiliário da "sala de conferências" como um espaço com "cavaletes de madeira, estrado com 30 cadeiras e 30 carteiras, mappas grandes (estudos sobre as diversas peçonhas brasileiras), regulares, médios e pequenos (diversas demonstrações ophidicas), escarradeiras, quadros a óleo"; no de 1921, quando Rudolph Kraus ressalta que elas "têm tido acolhimento favoravel, pois têm sido muito concorridas" e de 1929, em uma imagem fotográfica retratando a "nova sala de conferências", com painéis e vitrinas e capacidade para mais de 60 pessoas (Figura 1).

Isso sugere que as conferências passaram a ser tão rotineiras às atividades do Instituto que já não eram mais registradas em seus relatórios. Para Santos (1998), o trabalho pioneiro de Vital Brazil na prevenção de acidentes ofídicos por meio dessas conferências, bem como de outras atividades de caráter educacional, foi se incorporando de "tal forma ao espírito do Instituto, que hoje, ele é mesmo ignorado como uma atividade específica”.

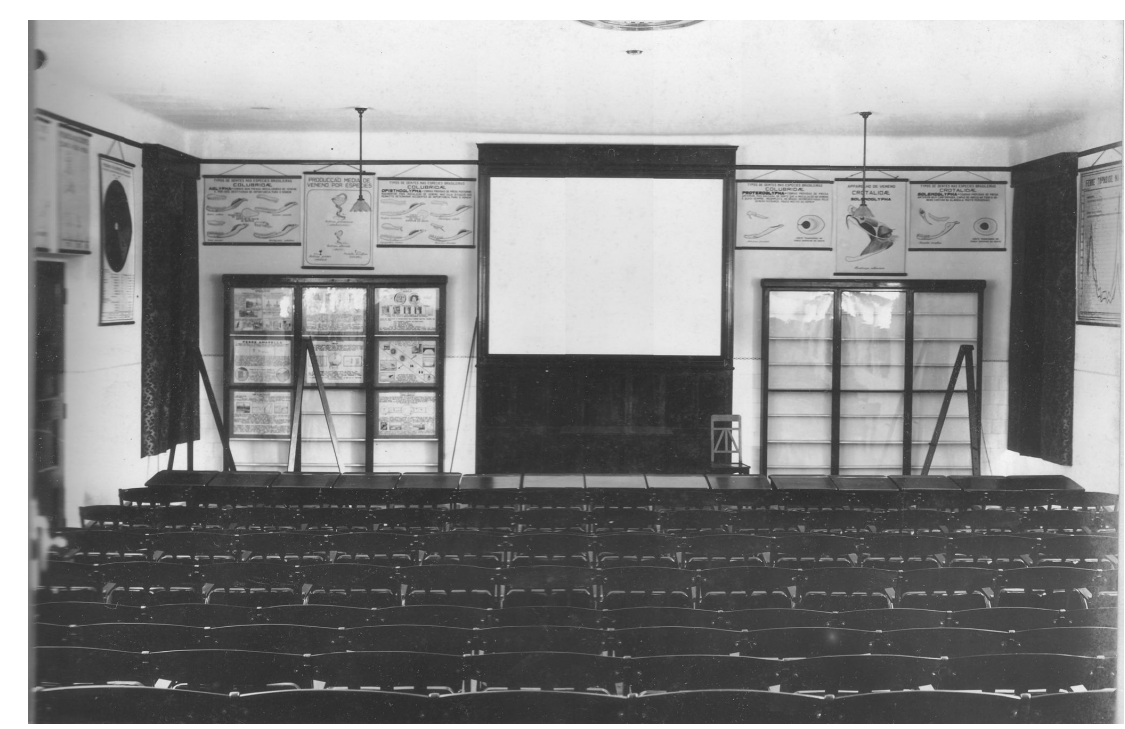

Figura 1. Sala de conferências do Instituto Butantan, em 1929 (Acervo Iconográfico do Instituto Butantan).

O Estado de São Paulo, 04/05/1914 - "Ligeiro Histórico do Bélo Estabelecimento Científico - A Obra do Dr. Vital Brasil - A Nova Instalação, a inaugurar-se hoje”. In: BRAZIL, V. Memória Histórica do Instituto Butantan. São Paulo: Elvino Pocai, 1941. 170p. 
A partir da década de 1950, os relatórios anuais passaram a apresentar um item estruturado como "atividades didáticas": eram relatados os cursos, palestras e conferências ocorridos em cada ano. Em 1958, muitas das seções do Instituto também começam a apresentar, junto com suas atividades científicas, as suas atividades de rotina, comunicações e participações em congressos. Nesse ano, Wolfgang Bücherl, então diretor do Museu do Instituto Butantan (atual Museu Biológico) ofereceu uma conferência sobre como "montar" um estabelecimento desse tipo: "Organização de um museu científico".

Atualmente, numerosas e diversas são as palestras desenvolvidas pelo Butantan, para as comunidades externa e interna. O registro de todas elas tornou-se uma tarefa árdua, devido não somente ao seu número significativo, mas também à autonomia dos profissionais do Instituto em ministrar palestras e aulas. A Divisão de Desenvolvimento Cultural, bem como o Instituto, procuram registrá-las por meio de um informativo interno e, anualmente, pelos relatórios desenvolvidos pelos chefes de cada seção, com a descrição de todas as práticas desenvolvidas por seus funcionários.

\section{Cursos de curta e longa duração}

Uma preocupação da instituição, constante em diversos documentos oficiais, é a formação de profissionais para atuar na área de saúde pública, direta ou indiretamente.

Já no final da década de 20, o Instituto Butantan organizou dois cursos de higiene para inspetores escolares, diretores de grupo e professores, em resposta ao pedido do Inspetor Geral de Instrução Pública ${ }^{4}$. Havia a intenção de elaborar um curso de educação sanitária principalmente para grupos escolares mais distantes e de "onde mais se fizessem sentir a acção da hygiene e consequentemente onde maior necessidade houvesse de applicação immediata dos ensinamentos a serem vulgarisados" ". A "materia do curso" foi condensada em poucos dias devido à presença de educadores do interior do estado, escolhendo-se "entre muitos pontos importantes os que maior interesse poderiam offerecer sob o aspecto de sua applicação imediata" ${ }^{\text {. }}$ O curso era composto por partes "expositivas" (por exemplo, "Problema do saneamento", o "Papel da escola no saneamento", "Historico do Instituto", "Noções geraes de sorotherapia”), partes "praticas" ("Sangria de um cavallo para preparo do soro", "Extracção de peçonha", "Exames de leite, farinhas" etc.) e partes "recreativas" (visitas a instituições como o "desinfectorio" e a Faculdade de Medicina). No final dos cursos, era entregue um questionário aos educadores, com questões avaliativas. Um dos

\footnotetext{
Relatório Anual de 1918.

Ibidem.

Ibidem.
} 
questionamentos era identificar se o educador tinha a intenção de elaborar um museu escolar em seu local de atuação, ocorrendo respostas positivas em todos os casos. Como relata Almeida (1995), os museus escolares ganharam força no Brasil na década de 1930 e se propunham "à formação de coleções de objetos, seres naturais, mapas, gráficos que auxiliariam no ensino. Os alunos coletariam os materiais, com orientação dos professores, e colaboração de outros órgãos públicos". A essa proposta, pode estar associado o fornecimento, pelo Butantan, de kits de serpentes fixadas em álcool para as escolas que conseguissem 50 fornecedores de serpentes ${ }^{7}$.

Além dos cursos para inspetores e diretores de grupos, eram organizados também cursos técnicos, de curta e longa duração, voltados para o aprimoramento de estudantes e profissionais da área médica. No Relatório de 1921, o então diretor Rudolph Kraus cita a organização de encontros semanais (suspensos um ano depois ${ }^{8}$ ) para os técnicos do Instituto, com o objetivo de divulgação de artigos científicos. No mesmo ano, foi organizado um curso de Microbiologia para novos funcionários e para o aperfeiçoamento de médicos. Para Oliveira (1980, p. 30), esse e outros cursos eram programados "análogos àqueles do Instituto Pasteur e Instituto Koch". Além disso, foram organizadas conferências sobre doenças infecciosas e sua profilaxia, voltadas também para profissionais da área ${ }^{9}$.

As conferências de caráter técnico, dirigidas à profissionalização de funcionários do Instituto e de estudantes da área biomédica, eram relatadas separadamente das conferências voltadas para o público em geral. O relatório de Kraus, citado anteriormente, deixa claro que havia as conferências populares e as conferências técnicas. Em relação a essas últimas, observa-se que as temáticas eram variadas, percorrendo principalmente as áreas de soroterapia, microbiologia e patologia, fundamentais para as atividades de pesquisa e produção do Instituto. As conferências técnicas acompanharam ainda as demandas externas, sendo ministradas em sociedades científicas, como a Associação Paulista de Medicina ${ }^{10}$.

Havia claramente uma tentativa de diversificação temática dos cursos ministrados no Butantan, que ia muito além do ofidismo. Em 1936, por exemplo, foram ministrados cursos de extensão universitária sobre endocrinologia e sobre hormônios sexuais femininos e mecanismos do parto, além dos já conhecidos Cursos para Médicos (Figura 2).

Relatório Anual de 1918. Essa prática permaneceu durante todo o século, sendo registrados os números de animais doados a cada ano.

8 Relatório Anual de 1922.

9 As conferências técnicas foram consideradas aqui como cursos de curta duração, pois possuíam um caráter de educação profissionalizante e, muitas vezes, tinham maior duração.

10 Relatório Anual de 1942. 


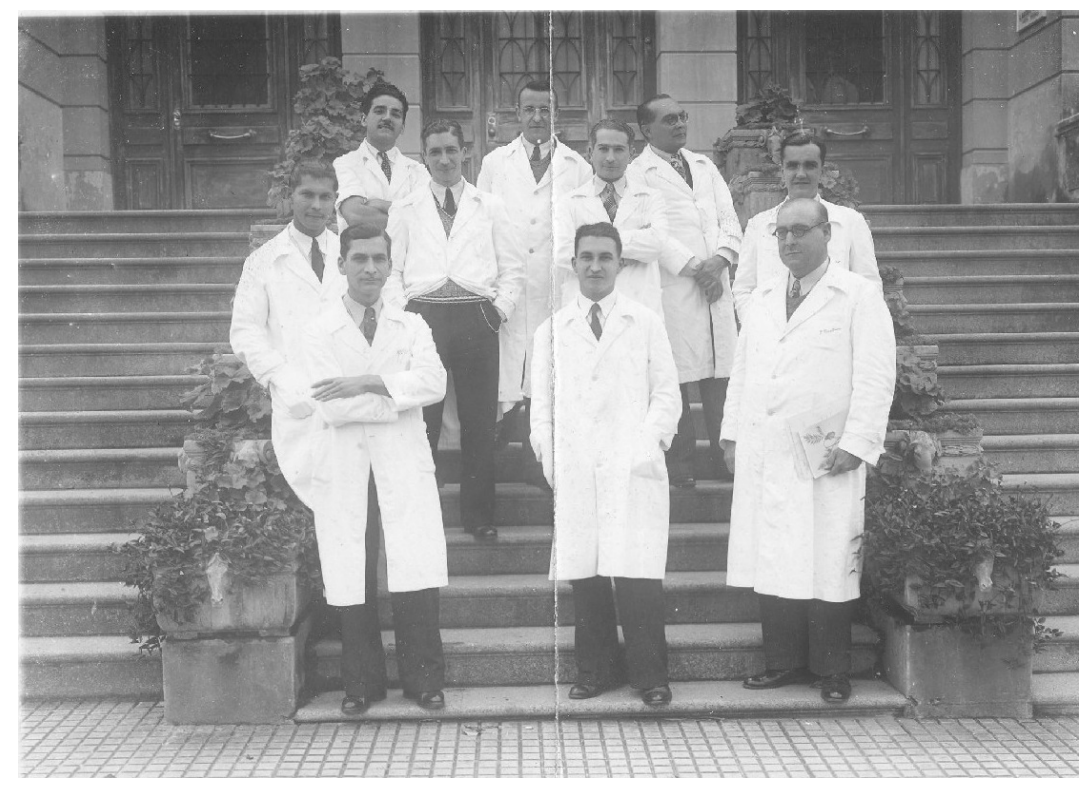

Figura 2. Turma de médicos formados em 1939 no curso oferecido pelo Instituto Butantan (Acervo Iconográfico do Instituto Butantan).

Esse aumento no oferecimento de cursos, em frequiência e temas, pode ter refletido a necessidade, cada vez maior, de formação especializada para o desenvolvimento das atividades do Instituto. Nesse período, acompanhando um movimento nacional, o Butantan apresentou um importante aumento na diversidade e na complexidade das pesquisas realizadas. Segundo Pimont (1973), a universidade responsabilizava-se pela formação básica, mas a formação específica para o trabalho nos laboratórios de pesquisa teria que partir do próprio Instituto.

Assim, em 1942, foi programado um curso sobre "Patologia Experimental", que deveria ser aprovado pelo Conselho Universitário da Universidade de São Paulo pois, segundo a autora, o Instituto era um órgão complementar da mesma. Para Pimont, essa proposta deixou marcas importantes para a ação comunicativa da instituição, tornando-se o primeiro passo para a sistematização de suas atividades didáticas que, até então, "eram difusas, descontínuas, assistemáticas e que se constituíam em atendimentos a grupos esporádicos, interessados principalmente em ofidismo" (PIMONT, 1973, p. 52).

O curso, com programa baseado nas áreas de Imunologia, Bacteriologia, Parasitologia, Vírus Filtráveis e Animais Venenosos, somente foi iniciado em 1952. Em sua segunda edição, passou a ser estruturado em duas etapas: no primeiro ano (Curso Básico Experimental), estavam presentes as disciplinas de Estatística, Bioquímica, Fisiologia, Farmacodinâmica; no segundo ano (Curso de Especialização), os alunos cursavam as disciplinas de Anatomia Patológica, Bioquímica, 
Hematologia, Imunologia e Bacteriologia, Ofiologia e Zoologia Médica, Parasitologia e Virulogia. Esse curso foi ministrado somente duas vezes: a primeira turma foi composta por 19 alunos e a segunda, por dois estudantes (PIMONT, 1973).

A esse curso, que recebia título de Especialização e era considerado de pós-graduação universitária, seguiram-se outros também aprovados pelo Conselho Universitário, totalizando-se 11 cursos diferentes, todos na área de ciências biomédicas, oferecidos a 223 alunos (em 39 turmas), entre os anos de 1952 e 1965 (PIMONT, 1973).

Enquanto os cursos de especialização versavam sobre diferentes disciplinas (de 11 cursos, somente dois referiam-se a animais peçonhentos: Artropodologia e Ofiologia), os cursos de atualização e divulgação eram mais restritos. Voltados para um público mais amplo, que incluía enfermeiras, militares com trabalho de campo, oficiais da FAB (Força Aérea Brasileira), entre outros, eram ministrados no Brasil e no exterior e focavam, em quatro aulas, a identificação e coleta de animais peçonhentos, conhecimentos sobre os soros e os primeiros socorros em caso de acidentes com esses animais (PIMONT, 1973). Segundo a autora, de 1957 a 1966, foram ministrados 37 destes cursos e 126 aulas.

Os cursos de curta duração foram constantes ao longo nas próximas décadas. Hoje, são oferecidos anualmente seis cursos de Nível Básico e 18 cursos de Extensão Universitária, em diferentes áreas. O Instituto Butantan está credenciado em dois programas de Pós-Graduação: o Interunidades em Biotecnologia (USP/IPT/IBu) e em Infectologia (Coordenação dos Institutos de Pesquisa), ambos reconhecidos pela CAPES, nas modalidades mestrado e doutorado.

\section{O Grupo Escolar Rural de Butantan}

Já no relatório Anual de 1917, Vital Brazil cita que anos antes havia sido implantada uma escola mista destinada à instrução dos filhos de funcionários e crianças de áreas vizinhas da Fazenda Butantan. Nesse mesmo documento, ressalta a necessidade de desdobrar essa escola em duas, separando-se meninos e meninas, e de construir um novo espaço para abrigá-las. A escola iniciou suas atividades em um barracão que servira provisoriamente de laboratório e, como aponta o Relatório de 1919, funcionava em "predio acanhado ao extremo, sem ar e sem luz, em flagrante desaccordo com os principios de hygiene moderna". No final da década de 1920, passou a ocupar o edifício que abrigava a residência do diretor do Instituto (antiga sede da Fazenda) (Figuras 3 e 4). 


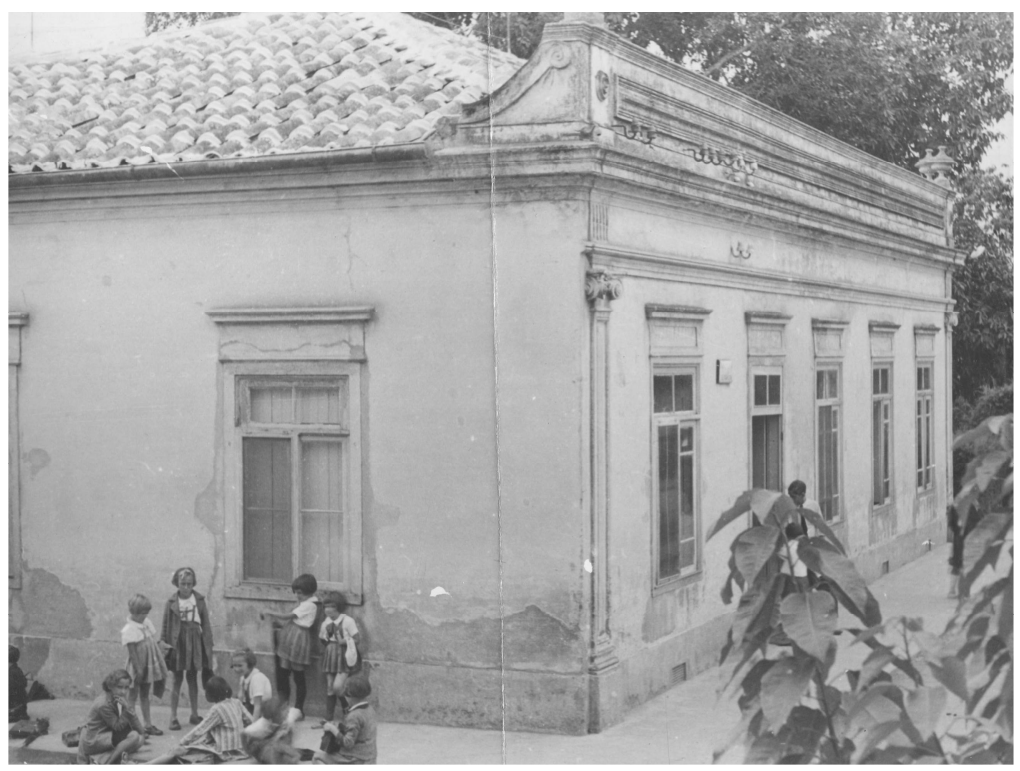

Figura 3. Grupo Escolar de Butantan, no final da década de 1920 (Acervo Iconográfico do Instituto Butantan).

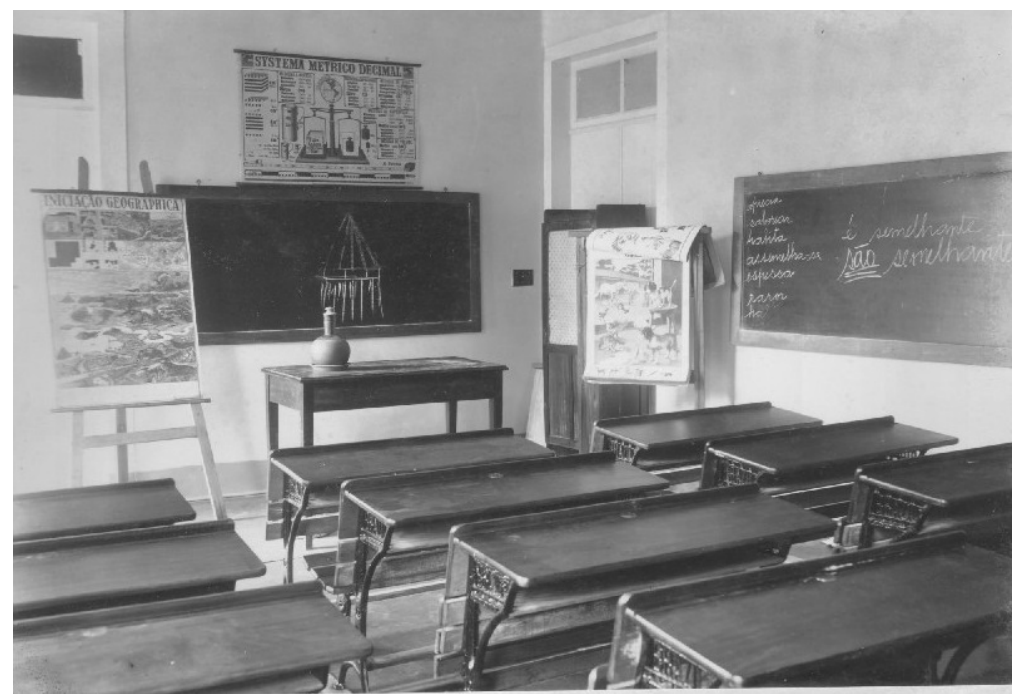

Figura 4. Sala de aula do Grupo Escolar de Butantan, em 1929 (Acervo Iconográfico do Instituto Butantan).

Foi nessa época que o Grupo Escolar, transformado em "Grupo Rural do Instituto Butantan"11, inseriu-se no movimento do ruralismo pedagógico no Brasil, principalmente pelas ações de sua professora e diretora Noêmia Saraiva Mattos Cruz. Educadora sanitária, normalista e

11 O Grupo Rural do Butantan foi criado em 1932, voltado para um "ensino ruralizado" (DEMARTINI, 2002). A Educação Rural no Brasil voltou ao cenário das políticas educacionais na década de 1930, quando as propostas de reduzir os preconceitos que marcavam os trabalhos agrícolas e, ao mesmo tempo, de garantir a fixação do homem ao campo foram assumidas por políticos da área educacional. 
com vários cursos e estágios na Escola Agrícola Luiz de Queiroz, Noêmia implementou na escola do Butantan um novo viés da proposta de Ensino Rural vigente na época. Com uma prática pedagógica que acabou por se distanciar das idéias ruralistas originais, ampliou a visão de um ensino restrito às questões do campo, considerando que a educação rural tornaria a criança uma investigadora de suas próprias experiências, a partir de observações, abstrações e generalizações. Criou, assim, um modelo que foi utilizado na implantação de escolas ruralistas em outros estados brasileiros (DEMARTINI, 2002).

Para Santos (1998), as práticas pedagógicas observadas a partir de imagens registradas na década de 1930, como o cuidado com a terra, o plantio de hortaliças, as regas, lembram a "Pedagogia do Sensível”, de Freinet, com idéias sobre "a pedagogia através do trabalho, encontro de culturas, livre expressão, jornal escolar" que ainda não haviam aportado no Brasil. Inclusive, é produzido no grupo um jornal chamado "Escola Rural de Butantan: Rumo ao Campo", com textos dos próprios alunos descrevendo suas experimentações vivenciadas dentro e fora da escola e com dicas sobre o cultivo de vegetais. Santos (1998), descreve a proposta do grupo escolar como uma educação voltada para o campo, para o cultivo do cultivo, para a "Cultura das Culturas para a Cultura, no seu sentido agrário".

Na década de 1950, o Grupo Escolar Rural de Butantan chegou a ter "um milheiro de alunos”. Posteriormente, passou a constituir a Escola Estadual Alberto Torres, localizada atualmente na entrada do Instituto Butantan.

\section{Produção de materiais impressos}

Foram encontrados poucos registros dos materiais impressos produzidos pelo Instituto para divulgação científica até a década de 1980. Foi possível observar a presença de quadros didáticos em algumas imagens do acervo iconográfico da instituição (como na Figura 1, apresentada anteriormente), mas são poucos os materiais que puderam ser analisados como fonte documental primária.

Nos escassos materiais encontrados, percebe-se um foco na comunicação por meio de textos geralmente curtos e de imagens chamativas. Em alguns casos, são utilizados termos e nomenclatura científicos. São focados a necessidade de posturas higiênicas no cotidiano e os aspectos da biologia e morfologia dos animais peçonhentos e organismos patogênicos. Nos materiais relacionados às parasitoses, há uma preocupação com a etiologia da doença, os mecanismos de propagação, a profilaxia e o tratamento recomendado. Principalmente nesses materiais, vê-se a tentativa de colocar na população a responsabilidade pela prevenção da doença (Figuras 5 e 6). 


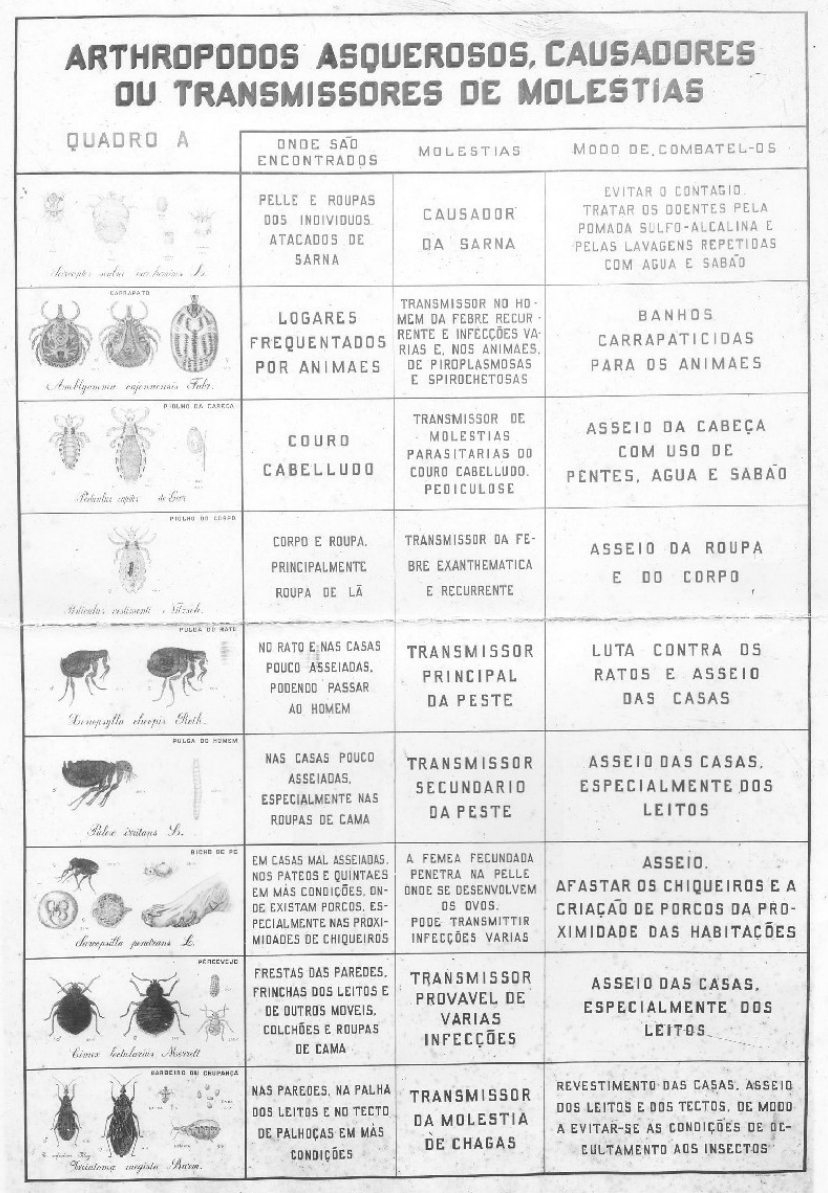

Figura 5. Pôster sobre artrópodes causadores ou transmissores de doenças (antes de 1938, Acervo Iconográfico do Instituto Butantan).

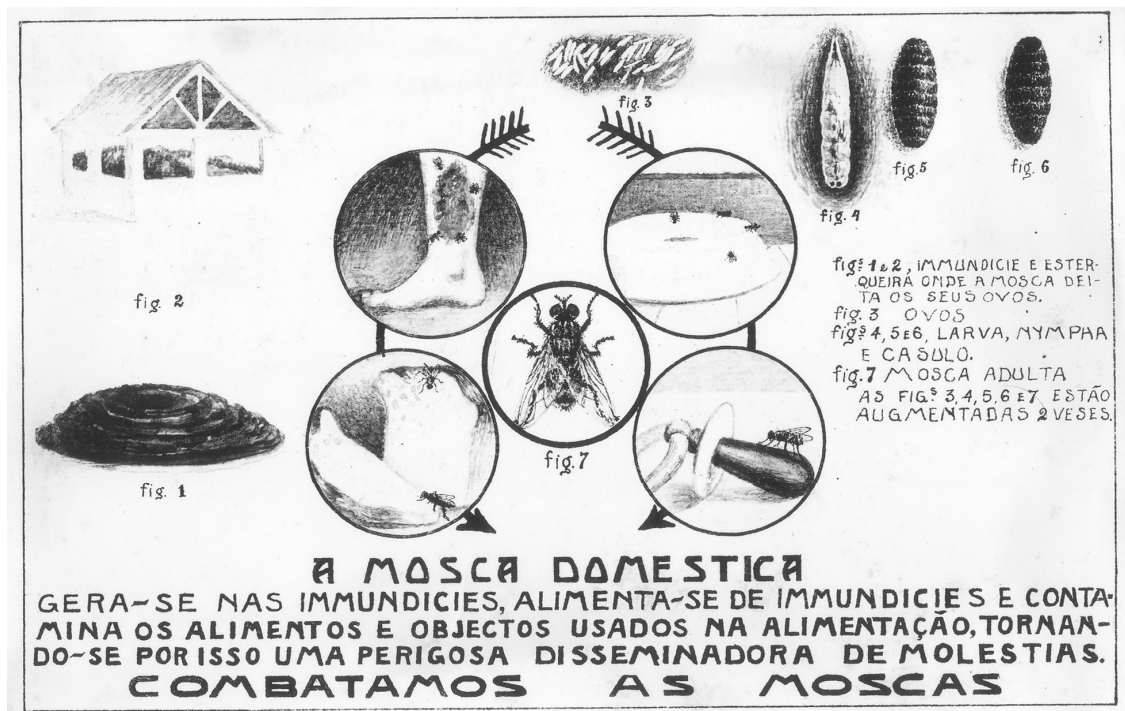

Figura 6. Folheto sobre o ciclo de vida e os hábitos da mosca doméstica (antes de 1938, Acervo Iconográfico do Instituto Butantan). 
Analisando-se os materiais impressos depositados no Acervo Iconográfico do Instituto Butantan, observa-se a maior disponibilidade institucional para a divulgação das temáticas relacionadas aos animais peçonhentos. Um exemplo bastante ilustrativo é o cartaz, sem data conhecida $^{12}$, ressaltando a importância do combate à tuberculose. Mesmo na divulgação sobre uma doença causada por um outro organismo que não uma serpente, é aproveitada a imagem dos ofídios (Figura 7).

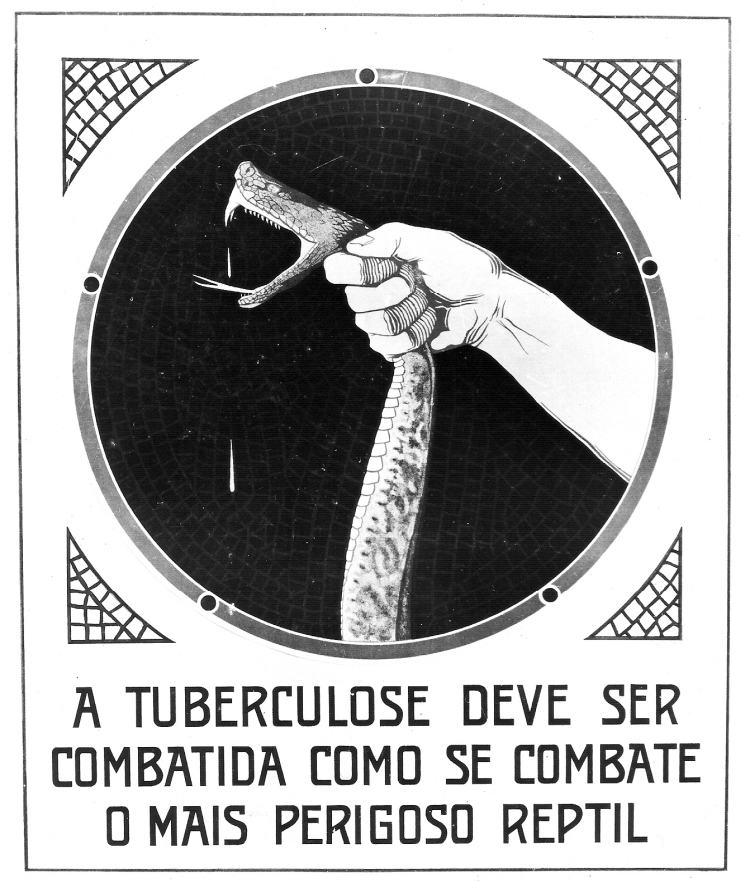

Figura 7. Pôster de divulgação do combate à tuberculose (s/d, Acervo Iconográfico do Instituto Butantan).

Na maioria dos casos, não é divulgada a autoria desses materiais. Somente nos impressos mais recentes foi possível detectar os elaboradores (assinatura direta no material ou registro posterior). Como exemplo, temos os materiais produzidos pelos pesquisadores Alma Hoge e Alphonse Hoge, do Laboratório de Herpetologia, na década de 70. O material tinha como objetivo fornecer informações sobre a identificação de serpentes perigosas e dava sugestões sobre prevenção de acidentes, como o uso de botas adequadas e de laços para captura. O material ainda convidava ao fornecimento de serpentes ao Instituto, explicitando que para cada duas cobras vivas entregues, o fornecedor receberia uma ampola de soro ${ }^{13}$ (Figura 8).

12 É bastante difícil encontrar uma provável data deste cartaz. A vacina contra a tuberculose (BCG) começou a ser produzida pelo Instituto em 1928 e, na década de 1950, já se falava em campanha contra a tuberculose, como observado em Fonseca (1954).

13 A permuta de serpentes por soro foi uma prática realizada, como citado, desde o início da distribuição do produto pelo Instituto. Em alguns períodos, como na gestão de Afrânio do Amaral, as cobras eram compradas. Segundo Oliveira (1980), o pagamento em dinheiro feria o objetivo principal do contato com o fornecedor, que era o de obter 


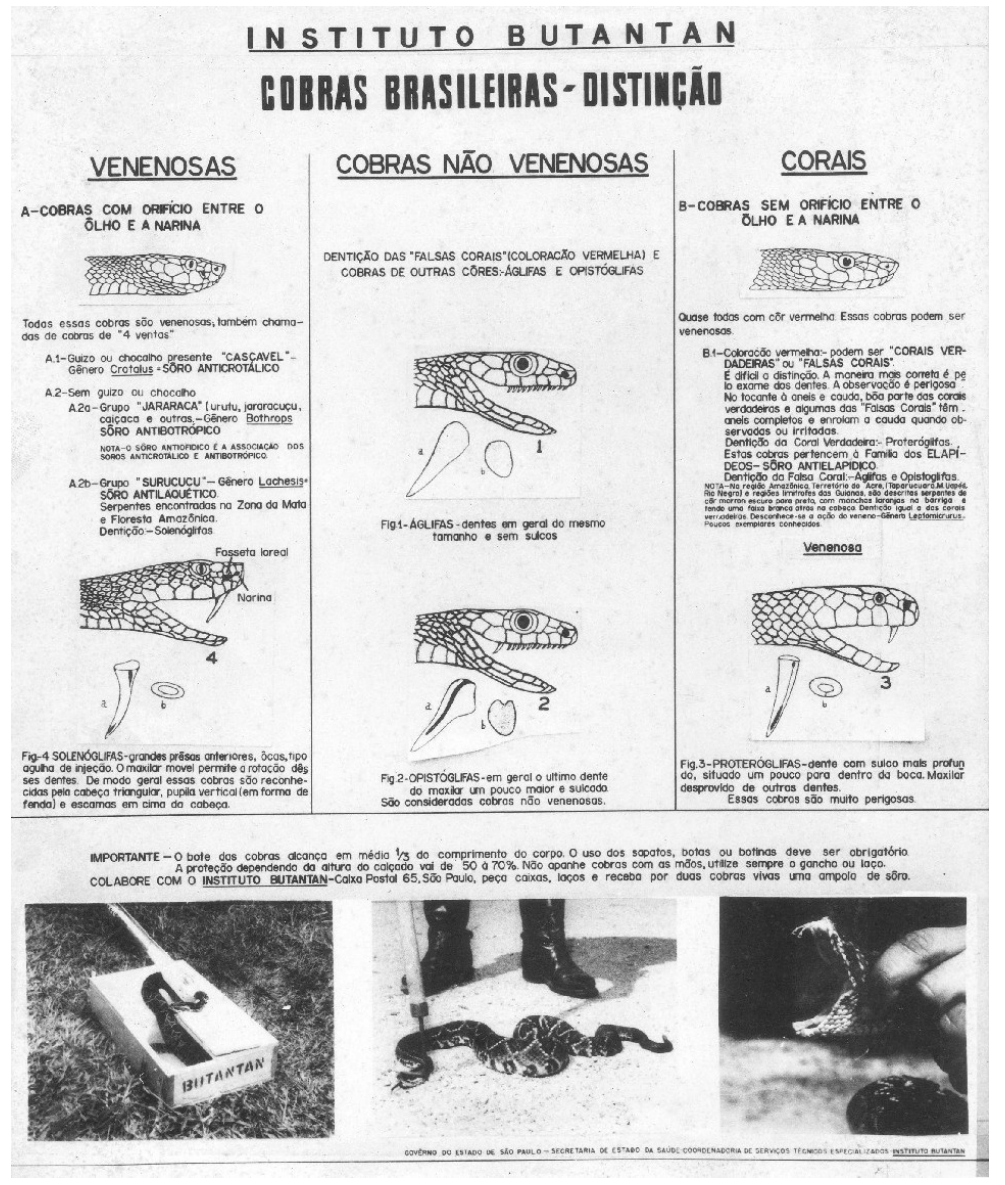

Figura 8. Folheto produzido por pesquisadores do Laboratório de Herpetologia do Instituto Butantan na década de 1970 (Acervo Iconográfico do Instituto Butantan).

É a partir dessa década e, principalmente da década de 1980, que os materiais impressos atualmente distribuídos pelo Instituto foram produzidos. A Série Didática do Instituto Butantan, por exemplo, é fruto do projeto iniciado nesse período, que tinha como responsável Rosa Pavone Pimont e como colaboradores, Célia Regina Russo, Luiz Fernando Cunha, Regina Cecília Pressler e Henrique Moises Canter, sendo editada desde então, em geral, com pequenas modificações em seu texto (a atualização dá-se, principalmente, com a inserção de novos informativos). Atualmente, são 11 números disponibilizados para impressão no website da instituição.

A produção de materiais impressos que seguiu a esse período é bastante relevante: somente entre os anos de 1987 e 1994 foram publicados aproximadamente 800.000 exemplares de cartilhas, manuais, cartazes, folhetos e fôlderes (SANTOS, 1998).

o veneno para produção de soro, mas, ao mesmo tempo, colocar "nas mãos dos agricultores" o soro antiofídico. A permuta seria mais eficiente do que a compra para garantir que a população com maior risco de acidentes tivesse maior acesso aos produtos. Atualmente, a prática de permuta foi abolida, pois é defendido institucionalmente que a aplicação do soro necessita de um profissional capacitado para tal. 


\section{Bulas}

O material que acompanhava os soros e vacinas distribuídos pelo Instituto Butantan merecem um olhar especial. Desde as primeiras doses oferecidas à população, as bulas tornaram-se um meio de comunicação com o público: ao mesmo tempo em que Vital Brazil demonstrava sua preocupação em informar os conhecimentos produzidos sobre os animais venenosos, as ações do veneno e as medidas de prevenção, pretendia também obter informações do uso do produto por meio de questionários destinados aos usuários.

No acervo pesquisado, foram encontradas outras bulas, sem data precisa (embora sejam provavelmente das décadas de 30 ou 40, quando os prefixos dos números de telefone paulistanos eram compostos por somente um algarismo). Eram feitas de papel de baixa gramatura, facilmente dobrável. Constituíam-se em um verdadeiro material de divulgação científica típico da época, pois além de fornecerem instruções sobre a utilização do produto, traziam também informações sobre a biologia dos animais peçonhentos, imagens para ajudar na sua identificação, esquemas com as marcas deixadas pelas picadas, bem como formas de prevenção de acidentes e primeiros socorros (Figura 9).

a

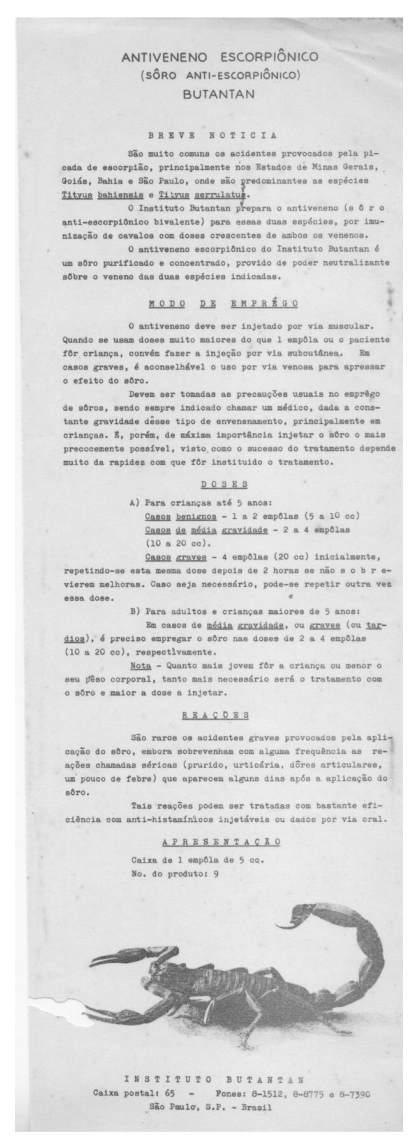

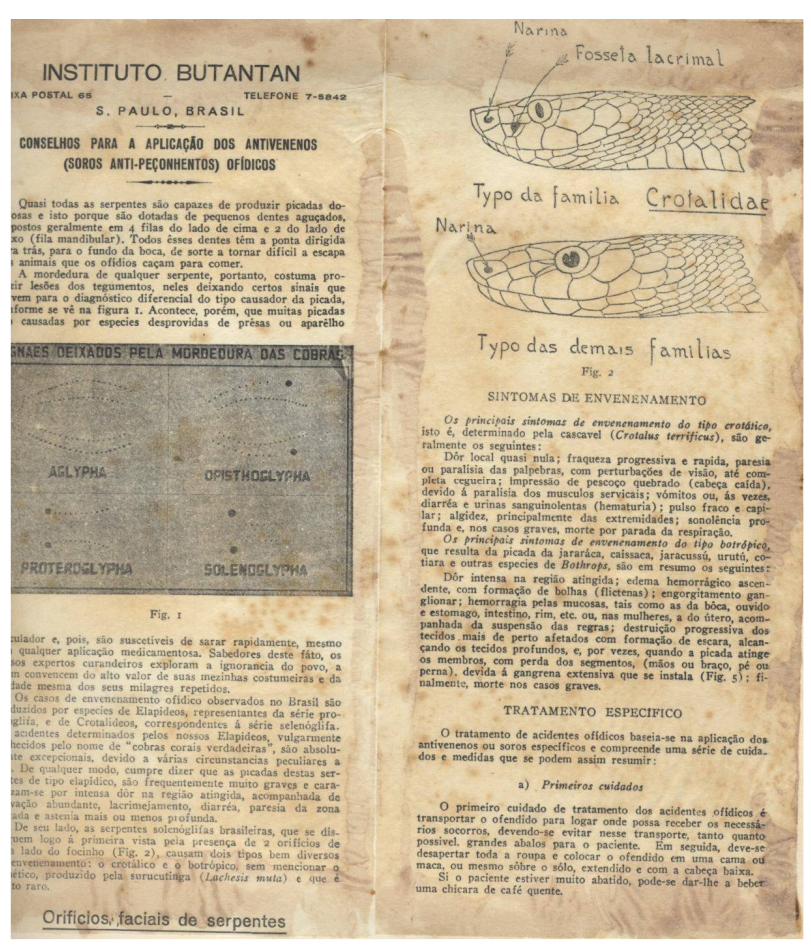

b

Figura 9. Bulas que acompanhavam as ampolas de a) soro antiescorpiônico e b) soro antiofídico (s/d, Acervo: Laboratório Especial de História da Ciência do Instituto Butantan). 
As bulas mais recentes são mais concisas e não são reformuladas há anos. Atualmente, são distribuídas com todos os 25 soros, vacinas e biofármacos produzidos na instituição.

\section{Publicações em revistas e jornais}

A publicação de artigos em revistas ou jornais por profissionais da instituição parece não ter sido uma prática continuada ao longo do século passado. Foram poucos os artigos localizados e não há registros de suas publicações nos relatórios anuais. Não é possível saber se a falta de citações a esses e outros possíveis trabalhos deu-se por ausência real de publicações ou por desconsideração em relação à publicação de artigos de divulgação em periódicos não-científicos.

Em uma revista voltada para produtores agrícolas vendida em todo o território nacional, a "Sítios e Fazendas", foi encontrado um artigo anônimo, mas que provavelmente teve autoria ou foi assessorado por um profissional do Instituto. Publicado em 1954, versou sobre prevenção e identificação de animais peçonhentos e protocolo de aplicação de soros antiofídicos. As imagens apresentadas eram de um desenhista ligado ao Instituto Butantan e do livro "Serpentes do Brasil", de Afrânio do Amaral, profissional da instituição. É provável que artigos como esse fossem publicados por profissionais do Butantan, mas, pelas fontes de documentação utilizadas nessa pesquisa, não foi possível localizá-los.

Já os artigos em jornal retratando questões institucionais pareciam ser bastante freqüentes. Em seu livro "Memória Histórica do Instituto Butantan”, de 1941, Vital Brazil apresenta vários artigos publicados pelo jornal $O$ Estado de São Paulo, muitos deles com reprodução, na íntegra, de discursos e palestras proferidas por dirigentes do Butantan e de órgãos públicos ligados à saúde.

Embora esses artigos apareçam em número razoável, a relação da instituição com os veículos de comunicação em massa também teve pouca representação nas fontes utilizadas nessa pesquisa. Somente na década de 1980, vê-se citações de contato com meios de comunicação voltados para a comunicação em massa (rádio, TV, jornais). Uma sistematização de informações esparsas é necessária para um aprofundamento no tema. Recentemente, essas vias de comunicação foram estabelecidas e estruturadas, com a criação de uma Assessoria de Imprensa, em 2004.

\section{Exposições externas}

O primeiro relato encontrado de uma exposição em que o Instituto Butantan participou foi sobre a Exposição Internacional de Higiene, em 1907, anexa ao III Congresso Médico LatinoAmericano, em Montevidéu. Como outras instituições brasileiras, o Butantan levou fotografias de suas dependências, mas também amostras de soro antiofídico (ALMEIDA, 2005). No Rio de 
Janeiro, participou da edição seguinte desse congresso, com inserção na Exposição Internacional de Higiene de 1909. Entretanto, não foram encontradas descrições sobre a expografia utilizada. Há também a participação do Instituto na Exposição Internacional de Higiene, em 1911, na cidade de Dresden (Alemanha). Na imagem disponível que representa a sala de exposição das instituições brasileiras, não é possível localizar referências à instituição paulista.

Somente no Relatório Anual de 1939, foi possível encontrar uma descrição do que era exposto pelo Instituto. Nesse ano, foram enviados dois caixotes para a Exposição Internacional de Nova Iorque (27 edição contada a partir da Exposição Internacional de 1851): o primeiro continha uma coleção de serpentes e o segundo, produtos do Instituto Butantan (Figura 10).

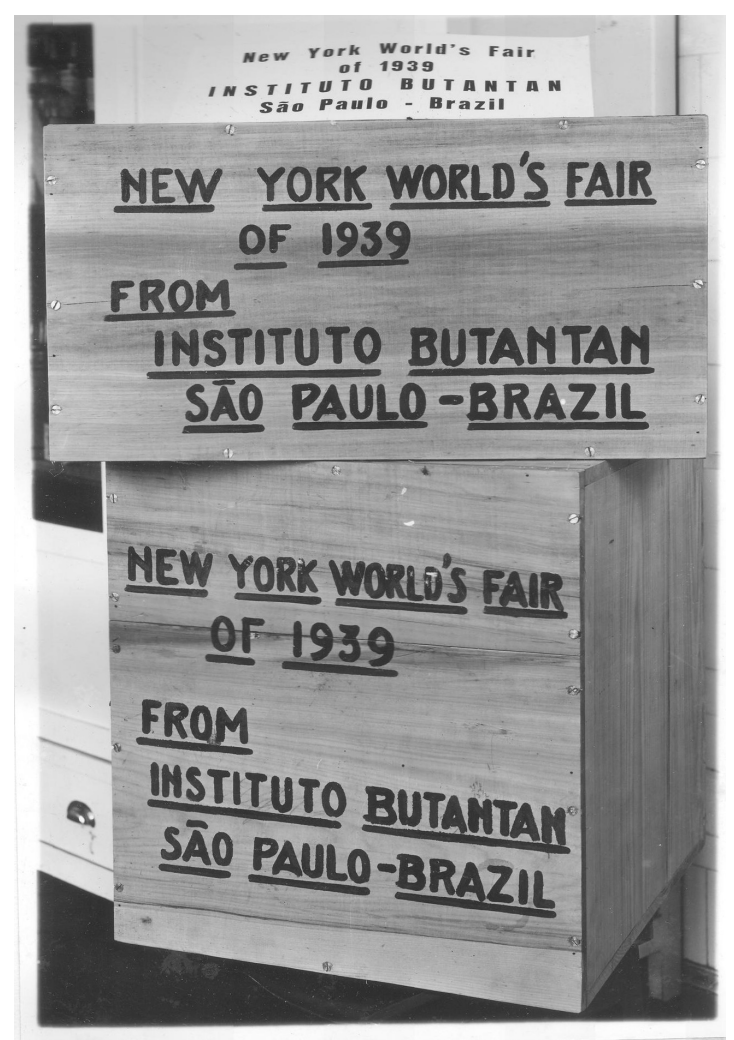

Figura 10. Material expositivo enviado pelo Instituto Butantan à Exposição Internacional de 1939, em Nova lorque (Acervo Iconográfico do Instituto Butantan).

Essa estrutura de exposição, com animais peçonhentos vivos ou fixados, peças biológicas (pele, hemi-pênis, ecdises, ovos, entre outras), ampolas e/ou caixas de soros e vacinas, constitui-se em uma lógica conceitual que permeou a maioria das atividades de divulgação científica e reflete-se nas discussões mais recentes dos grupos internos responsáveis pela elaboração de exposições.

Entretanto, uma exposição apresentada no I Encontro de Pesquisadores Científicos do Estado de São Paulo, em 1985, foge a essa regra. Em um espaço reduzido, de aproximadamente 
$3 \mathrm{~m}^{2}$, observa-se claramente uma expografia do momento político-administrativo da instituição: na década de 1980, chega à direção do Instituto o prof. Isaías Raw, médico considerado liderança científica, disposto a reestruturar a instituição em níveis profundos: da redefinição de suas diretrizes e missões à modernização da tecnologia empregada para a produção. É possível que daí tenha se extraído o conteúdo conceitual desse "stand": um Butantan sendo repensado e reconstruído (Figura 11). Uma parede de tijolos não terminada, fios soltos e os poucos objetos presentes são elementos expositivos bastante representativos desse momento de reestruturação do Instituto.

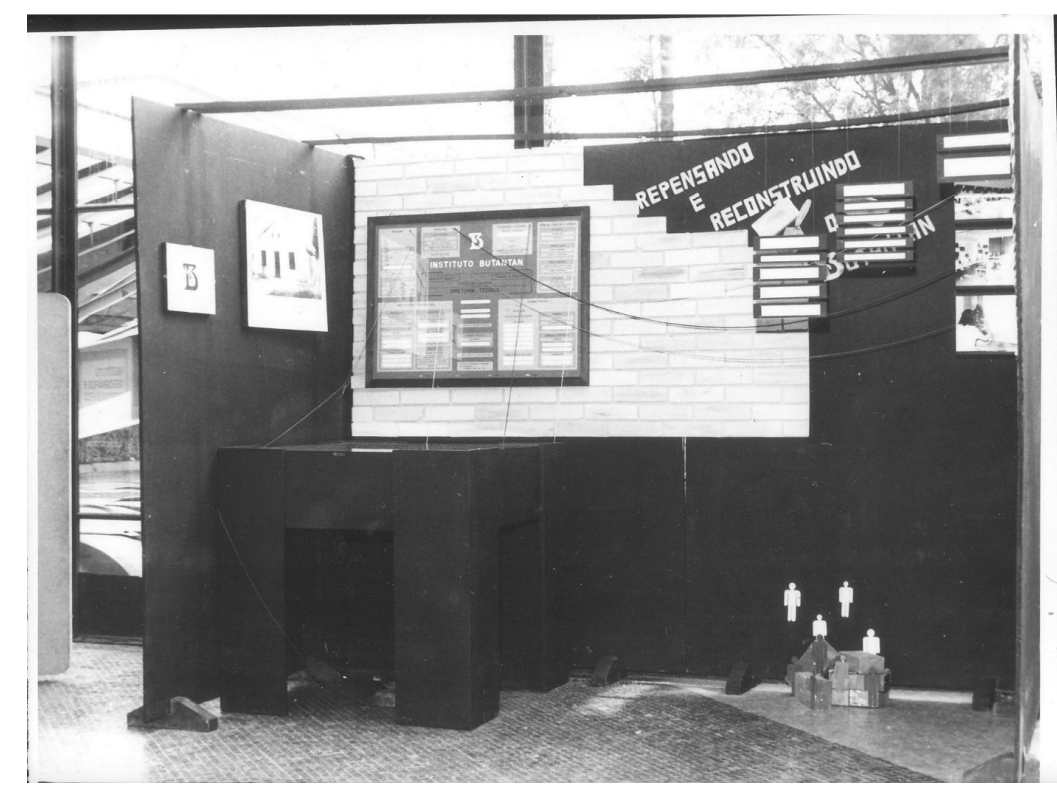

Figura 11. "Stand" do Butantan no I Encontro de Pesquisadores Científicos, São Paulo, 1985 (Acervo: Laboratório Especial de História da Ciência do Instituto Butantan).

O Instituto Butantan participa, há décadas (há registros desde a década de 1940), de atividades externas para grande público, como Feiras de Saúde e Feiras Agronômicas, entre outros eventos culturais, interagindo com cerca de 30.000 visitantes anuais. Até o momento, o Instituto vem participando desses eventos (em média dez por ano) com equipamentos expositivos reduzidos e não condizentes com a representatividade dessa instituição no cenário científico nacional. Uma exposição itinerante que atenda às expectativas da audiência do Instituto, bem como de sua equipe executora, está sendo elaborada com financiamento do CNPq, por meio do edital Ciência de Todos, lançado em 2004. Os soros e as serpentes não faltam nesse novo projeto. 


\section{Atendimento no parque}

O Instituto Butantan possui uma área aberta à visitação bastante atraente à população: o serpentário, o Museu de Rua, o macacário estão localizados em ruas e alamedas bastante arborizadas, constituindo-se em recurso de lazer em uma cidade com relativamente poucas opções culturais gratuitas ou de baixo custo. Assim, o Instituto Butantan atrai cerca de 240.000 visitantes anuais ${ }^{14}$, sendo que parte dessa audiência não visita os museus (pagos), somente o parque.

A visitação à área aberta da instituição pode ser observada desde os seus primeiros anos. Parte das demonstrações públicas realizadas ocorria na área externa e a construção de um serpentário fortaleceu essas atividades. Nesses fossos, as serpentes eram mantidas para extração de veneno e esse evento acabou se tornando um especial atrativo para a população, desejosa de ver um procedimento incomum em seu cotidiano.

Embora as citações diretas nos relatórios anuais sobre a visitação não fossem comuns, indiretamente observa-se que o parque do Instituto Butantan, embora distante do centro da cidade e, no início, de difícil acesso, ainda assim recebia visitantes. O serpentário, por exemplo, construído em 1912, foi projetado para a manutenção de cobras que eram enviadas do interior do estado, mas logo possibilitou aos visitantes a observação direta desses animais. Em um vídeo produzido pela Expedição ao Brasil do American Museum of Natural History, em 1926, vemos um serpentarista manuseando cascavéis e é possível visualizar uma placa, dentro do serpentário, com informações destinadas ao público. Outros indícios são encontrados nas fontes documentais primárias que evidenciam que o parque do Instituto Butantan logo se tornou um lugar, ao mesmo tempo, para lazer e acesso a informações científicas.

No Relatório Anual de 1938/40, o seguinte trecho revela algo sobre o público da instituição:

Como é sabido, constitue ele [o Butantan] em nosso Estado, o ponto de atração maxima para turistas, nacionais, como estrangeiros. Médicos, notoriedades mundiais da ciencia e da finança, diplomatas, militares, estudantes, ou mesmo simples turistas em viagem de recreio, procuram-no diariamente, para conhecer as suas instalações, admirar de perto os seus serpentários, visitar-lhe o museu. Em algarismos redondos, calcula-se em 100.000 por ano, o numero de visitantes.

Entre esse público, era comum a presença de turistas estrangeiros, principalmente de argentinos e ingleses (Figura 12).

14 Esses números estão baseados na contagem de público realizada pela Administração do Instituto Butantan que registrou a venda de 182.000 ingressos para os museus no ano de 2007 . Provavelmente, o número de visitantes do parque é ainda maior: segundo levantamento realizado em 2006 foram observados 120.000 visitantes não escolares (que corresponde a aproximadamente $50 \%$ do público total). 
a

VISITANTES EXTRANGEIROS

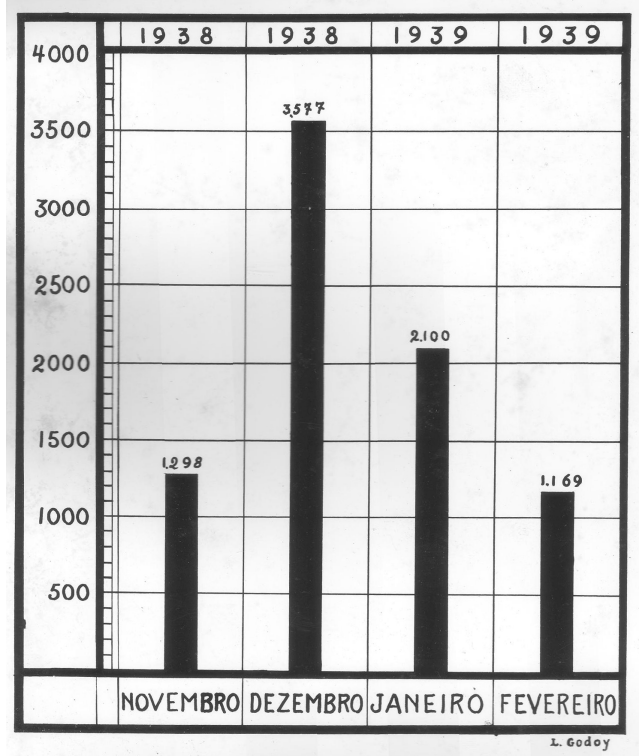

b

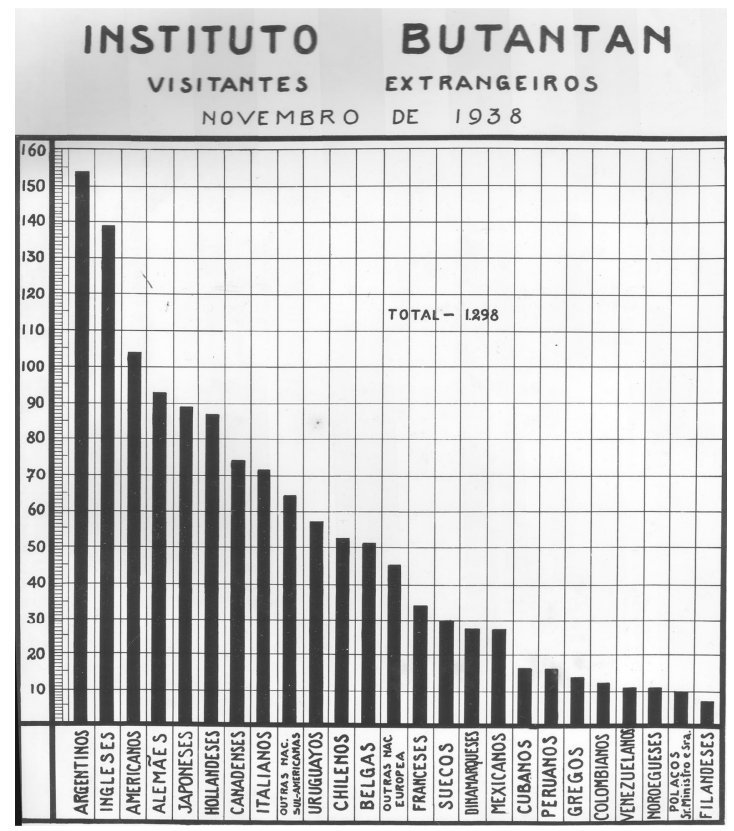

Figura 12. Número de turistas estrangeiros, por a) mês e b) nacionalidade, em 1938/39 (Acervo: Laboratório Especial de História da Ciência do Instituto Butantan).

Vê-se, com o crescente aporte de turistas, a necessidade de cuidados com "apresentação do Instituto aos olhos dos estranhos" ${ }^{15}$. Assim, sanitários, restaurante (para turistas e funcionários) e até mesmo um guarda-civil poliglota foram disponibilizados para o público.

O número de visitantes aumentou gradativamente a partir da década de 1960, tendo seu pico na década de 80. Pode-se acompanhar essa evolução ao olhar para o número de visitantes do Museu do Instituto Butantan (atual Museu Biológico). Em 1963, há início da cobrança de ingressos, o que pode estar relacionado à brusca queda de visitação: ou o público ressentiu-se com essa cobrança ou, a partir dessa medida, passou-se a haver um melhor controle do número de visitantes no Museu (Gráfico 1).

15 Relatório Anual de 1938/40. 


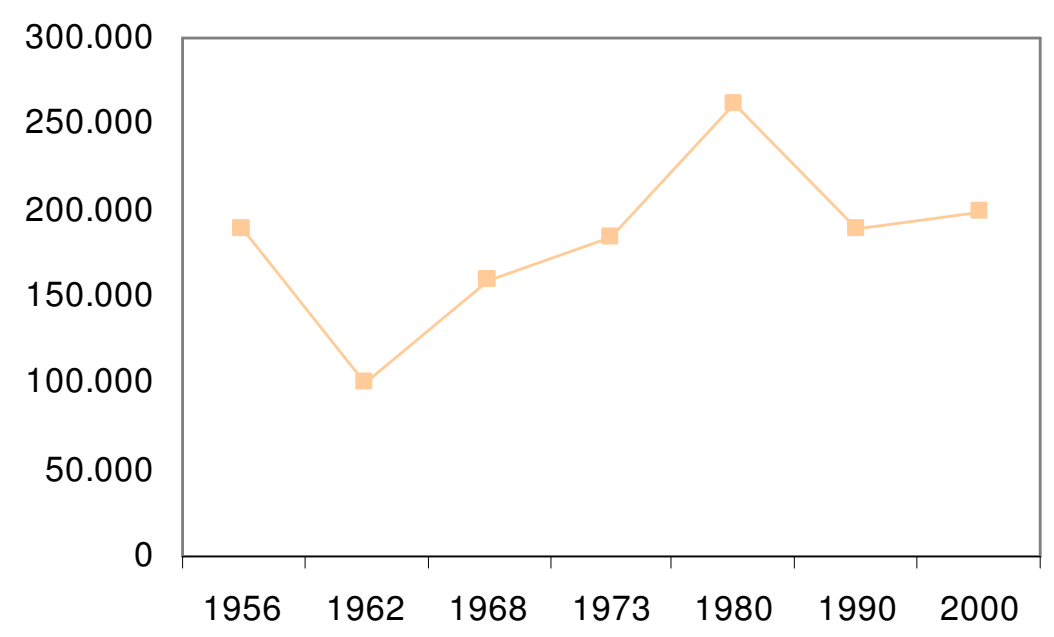

Gráfico 1. Variação do número de visitantes anuais no Museu do Instituto Butantan. Fontes dos dados: Relatórios Anuais do Instituto Butantan de 1956 a 1990 e documentos internos atuais.

Atualmente, percebe-se que o parque do Instituto, além de atrair um grande número de visitantes nos finais de semana, constitui-se, nos dias da semana, como rotas de passagem no cenário urbano, unindo uma via de intenso movimento, a Av. Vital Brasil, e as instalações da Universidade de São Paulo. Práticas educativas têm sido planejadas para esse público recorrente do Instituto, sendo uma delas a inauguração do Centro Cultural do Butantan.

\section{Outras coleções}

Nos documentos analisados foram encontradas iniciativas de apresentação ao público de acervos institucionais, referentes às pesquisas desenvolvidas no Butantan. Esses acervos foram disponibilizados para a visitação pública praticamente desde o início de suas formações. Em um primeiro momento, cumpriam, ao mesmo tempo, as funções de exposição pública e de pesquisa: eram utilizados para investigações científicas realizadas na instituição e também eram expostos ao público que visitava o parque ou assistia às conferências. Não se sabe ao certo em que período as coleções deixaram de ser expostas ou até mesmo usadas como fonte para as exposições museais e passaram a ser quase que exclusivamente destinadas à pesquisa científica.

Uma coleção utilizada com as duas finalidades (pesquisa e extroversão) foi a iniciada por Frederico Carlos Hoehne, em 1918, quando o Horto Oswaldo Cruz foi implementado no Butantan. O local foi destinado ao plantio de espécies vegetais de uso medicinal e indígena, para estudos 
fitoterápicos ${ }^{16}$. Embora a proposta inicial não tenha sido efetivada, Hoehne conseguiu organizar um herbário com mais de 4.000 exemplares (Figura 13), sendo que 300 deles eram expostos ao público no Museu Botânico (localizado em salas da Seção de Botânica), com bancadas de vidro e exsicatas expostas em armários (Figura 14). O acervo contava ainda com a coleção da extinta Pharmacia do Estado $^{17}$ e de materiais permutados com jardins botânicos estrangeiros ${ }^{18}$.

Não há muitos relatos sobre os visitantes do Museu Botânico, mas no Relatório de 1921, Hoehne afirma que, enquanto a Seção de Botânica foi transferida para o Instituto de Medicamentos Oficiais (cujo prédio situava-se na área do Instituto Butantan), o herbário permaneceu no Horto, para “conveniência do público".

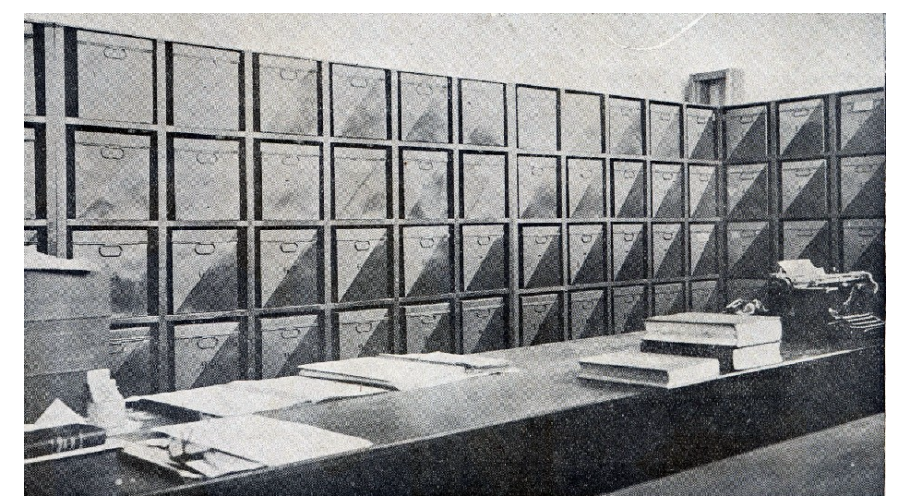

Figura 13 - Herbário da Seção de Botânica, no Instituto Butantan (Fonte: Memórias do Instituto Butantan).

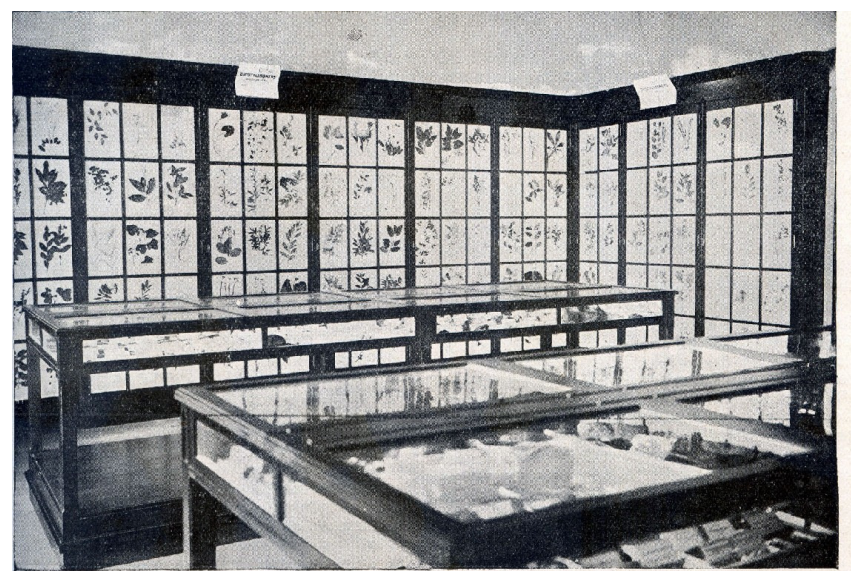

Figura 14. Museu Botânico do Instituto Butantan (Fonte: Memórias do Instituto Butantan).

16 Hoehne, F. C. O Horto Oswaldo Cruz e seus fins. In: Chacaras e Quintaes, 16(3): 196-197, 1917.

17 Relatório Anual de 1918.

18 Relatório Anual de 1920. 
Essa coleção, com o declínio das atividades botânicas do Horto, em 1923, passou a constar do acervo do Museu Paulista, para onde foi transferida toda a Seção de Botânica. Essa seção, posteriormente denominada Seção de Botânica Médica, foi reativada na década de 30, para a produção de medicamentos, embora não tenha tido resultados significativos (OLIVEIRA; MENDONÇA; PUORTO, 2005). Na década de 40, passou a constituir (juntamente com a Fisiologia), a Seção de Farmacologia, encerrando os estudos fitoterápicos.

Na década seguinte, o Horto passou a ser ocupado pela Seção de Parasitologia, chefiada por Flávio da Fonseca. Esse pesquisador organizou uma coleção de ácaros parasitas (iniciada em 1931) com mais de 80.000 exemplares e planejou um mostruário a ser exposto ao público. Entretanto, esse mostruário só é citado no Relatório Anual de 1940 e não é mais citado nos seguintes, sendo provável, como sugere Almeida (1995), que tenha ficado restrito ao uso de pesquisadores e estagiários. Atualmente, a Coleção Acarológica do Instituto Butantan encontra-se ligada ao Laboratório de Parasitologia (após quase 20 anos de vínculo ao Laboratório de Artrópodes Peçonhentos) e serve de base para o desenvolvimento de pesquisas científicas.

O mesmo direcionamento pode ser observado na Coleção Entomológica. Iniciada na década de 1910, com exemplares de insetos vetores de doenças recebidos pelo Instituto Butantan, foi estruturada na década de 1930 também por Flávio da Fonseca. Nesse período, foram incluídos na coleção importantes holótipos, halótipos e parátipos de hemípteros triatomíneos e outros insetos. Após a morte do pesquisador, a coleção permaneceu inalterada até a década de 1970, quando foi assumida por Lauro Pereira Travassos Filho. Atualmente, conta 3000 exemplares de coleópteros, himenópteros, hemípteros, dípteros, siphonápteros e lepidópteros ${ }^{19}$. Assim como a Coleção Acarológica, está vinculada ao Laboratório de Parasitologia. Apesar de sua representatividade para pesquisa entomológica no país, não foi e ainda não é representada nas exposições realizadas pela instituição. Há, hoje, um mostruário de insetos venenosos em diferentes estágios do ciclo de vida, utilizado em atividades educativas dentro e fora da instituição.

Já a Coleção Endocrinológica, proposta no Relatório Anual de 1940, a ser elaborada com peças anatômicas resultantes das experiências realizadas diariamente pela Seção de Endocrinologia, parece não ter sido nem mesmo implementada. Essa coleção foi proposta pelo então responsável pela seção, o assistente José Ribeiro do Valle, podendo servir de material de estudo e também de exposição para o desejado Museu Endocrinológico. Assim como outras iniciativas e propostas registradas nos Relatórios Anuais e outras fontes primárias analisadas, o Museu Endocrinológico também não foi levado adiante.

A Coleção de Aracnídeos e Miriápodes começou a ser estruturada, provavelmente, na década de 1920. Apesar de em 1905 já ter ocorrido a primeira tentativa de produção de soro

\footnotetext{
${ }^{19}$ Roberto Henrique Pinto Moraes (informação pessoal).
} 
antiescorpiônico, a produção em escala desse medicamento somente aconteceu 12 anos depois. Para essa maior produção, foi necessário o envio de técnicos para Minas Gerais para a coleta de espécimes de escorpião. Com essas viagens, ampliou-se o número de fornecedores de aracnídeos e conseqüentemente, o número de espécimes tombados na coleção (LUCAS, 2003). Não sabemos, ao certo, quando esses animais passaram a ser expostos, mas, no Relatório de 1919, Antonio P. De Ulhôa Cintra, então diretor do Instituto, ao realizar o inventário de bens da instituição, registrou a ocorrência na Sala do Museu de

3 braços de cera com demonstrações de vaccina.

1 braço de cera picado de aranha.

1 braço com pustulas malignas.

1 coto de braço com accidente ophidico.

1 cerebro.

1 dedo com accidente ophidico.

4 estantes nickeladas com vitrinas e tres prateleiras de vidro, sendo 3 completas e 1 sem portas e prateleiras.

2 estantes mostruarias, esmaltadas, frente do vidro, com serpentes de cera.

1 esqueleto de sucury.

2 jacarés.

1 mesa de lava.

1 maxxilar equidio.

1 pé natural com demonstração de accidente ophidico.

3 pés de cera com demonstração de accidente ophidico.

1 pulmão.

3 peças de porco com cysticercus.

3 peças de cera com ulcera de Baurú.

4 peças com vascularização.

33 peças de cera com ulceras atonicas e fagedenicas.

1 quadro com um corte transverso de um dente solenoglypha.

156 vidros com cobras conservadas (pequenos e medios).

34 vidros grandes com cobras conservadas.

2 vidros com barbeiros.

15 vidros com escorpiões, pequenos.

2 vidros com escorpiões africanos.

Em 1925, Jean Vellard, médico francês especialista em aracnídeos, assumiu a chefia do Museu. Segundo Lucas (2003), ao chegar ao Instituto, Vellard encontrou no acervo apenas duas aranhas caranguejeiras e dois vidros contendo vários exemplares em mau estado de conservação e sem procedência e identificação. Em relação à coleção de escorpiões, havia um número reduzido de 
espécies obtidas do Museu de História Natural de Paris, identificadas e guardadas em um armário do museu. Encontrou ainda um vidro com exemplares provenientes do Museu de Stuttgart, da Alemanha, além de exemplares brasileiros.

$\mathrm{Na}$ exposição organizada por Vellard, havia um armário destinado somente às aranhas, com "photographias, casinholas, ovos, etc, apanhados em (...) excursões". Um outro armário foi destinado a escorpiões, miriápodes e diplópodes. Além disso, quatro aranhas caranguejeiras vivas foram expostas em terrários.

Com a efetivação da produção dos soros antiescorpiônico e antiaracnídico, a recepção desses animais tornou-se mais evidente e esses exemplares passaram a constar do acervo da instituição. Entretanto, grande parte do acervo hoje tombado é proveniente de coletas realizadas por pesquisadores e técnicos da instituição.

\section{Os desejados e os novos museus do Instituto Butantan}

Ainda com as recentes reformas das exposições, que ocorreram nas últimas décadas, o tema condutor continuou a ser os animais venenosos. O mesmo se deu com a exposição "Parada Butantan”, na Estação Ciência, da Universidade de São Paulo: no espaço destinado ao Butantan, são expostos dioramas com animais vivos. Na visão de Almeida (1995), a temática "animais peçonhentos" sempre prevaleceu à "saúde pública" por um motivo específico: o Museu permaneceu continuamente sob responsabilidade de um zoólogo, pesquisador de animais peçonhentos e, em nenhum momento, contou com uma equipe interdisciplinar que, segundo a autora (e outros estudiosos), é “fundamental para o enriquecimento das experiências museológicas".

Mas a solução dessa questão já havia começado a ser traçada com a inauguração do Museu Histórico do Instituto Butantan, em 1981. Nessa nova exposição, pensava-se o Instituto com um outro viés, ressaltando seu mito de origem (um cientista especial que desenvolveu avanços importantes para a ciência em ambientes "paupérrimos"). O Museu Histórico, em seu início, teve o objetivo de "ser, através de exposições sempre renovadas a partir de pesquisa sobre seu acervo material e documental, o espelho da trajetória da instituição, desde sua criação até nossos dias" ${ }^{20}$. Hoje, com o auxílio do Laboratório Especial de História da Ciência, tem se voltado prioritariamente para a reestruturação e organização dos acervos históricos institucionais, incentivando a pesquisa e a comunicação, para posteriormente refleti-los em suas exposições.

Além do Museu Histórico, em 1991, foi inaugurado o "Museu de Rua" do Instituto Butantan, em comemoração dos 90 anos desse centro de pesquisa. Essa exposição, com 40 painéis contendo imagens e textos sobre o Butantan do século XX, permanece ainda hoje na alameda

20 Folheto de divulgação comemorativo dos 80 anos do Instituto Butantan e da inauguração do Museu Histórico. 
principal do parque, constituindo-se como uma "vitrina" das diversas atividades desenvolvidas na instituição em seus 90 anos.

Uma outra ação que vem ajudando a aproximar o antigo desejo institucional declarado (mas não executado) de ampliar a temática apresentada ao público é a implementação do Museu de Microbiologia do Instituto Butantan. Inaugurado em 2002, pretende divulgar pesquisas e novas tecnologias desenvolvidas pela instituição. Com uma expografia voltada para microrganismos e imunobiológicos, esse Museu realiza atividades de atendimento ao público que ressaltam os conteúdos abordados pela instituição que fogem da temática animais peçonhentos.

Os três museus do Instituto Butantan são os locais de atendimento ao público mais prontamente reconhecidos pelos visitantes. Mas, além de se constituírem como os locais de visitação por excelência, são também os agentes principais de elaboração de atividades e de pesquisa em divulgação científica e educação em ciências, juntamente com a diretoria da Divisão de Desenvolvimento Cultural e a Assessoria de Imprensa. Entretanto, vários laboratórios de pesquisa se disponibilizam ou são chamados a exercer essa função, como o Laboratório Especial de História da Ciência, o Laboratório de Ecologia e Evolução e o de Imunoquímica.

\section{Referências}

ALMEIDA, A. M. A relação do público com o museu do Instituto Butantan: análise da exposição "Na natureza não existem vilões". 1995. 215 f. Dissertação (Mestrado em Comunicação) - Escola de Comunicação e Artes, Universidade de São Paulo, São Paulo, 1995.

ALMEIDA, M. São Paulo na virada do século XX: um laboratório de saúde pública para o Brasil Tempo, Rio de Janeiro, v. 19, p. 77-89. 2005.

DEMARTINI, Z. B. F. Noêmia Saraiva de Mattos Cruz. In: FÁVERO, M. L. A.; BRITTO, J. M. (Orgs.). Dicionário de Educadores no Brasil. $2^{\text {a }}$ ed. Rio de Janeiro: Editora UFRJ/COMP/INEP, 2002. p. 854-859.

LUCAS, S. O Laboratório de Artrópodes do Instituto Butantan e os aracnídeos peçonhentos.

História, Ciências, Saúde - Manguinhos, Rio de Janeiro, vol. 10, n. 3, p. 1025-35, set-dez. 2003.

OLIVEIRA, A.; MENDONÇA, R.; PUORTO, G. Horto Oswaldo Cruz: histórico e projetos futuros. Cadernos de História da Ciência - Instituto Butantan, São Paulo, v. 1, n. 1, p. 82 - 90, jan. 2005.

PIMONT, R. P. A Área de Educação do Instituto Butantan. Memórias do Instituto Butantan, São Paulo, v. 37, p. 43-82. 1973.

SANTOS, M. F. Práticas Crepusculares: Mytho, Ciência e Educação no Instituto Butantan - um estudo de caso em antropologia filosófica. 1998. 2 vols. 658 f. Tese (Doutorado em Filosofia da Educação) - Faculdade de Educação, Universidade de São Paulo, São Paulo, 1998. 

APÊNDICE 2 - ROTEIRO DE ENTREVISTA JUNTO ÀS FAMÍLIAS.
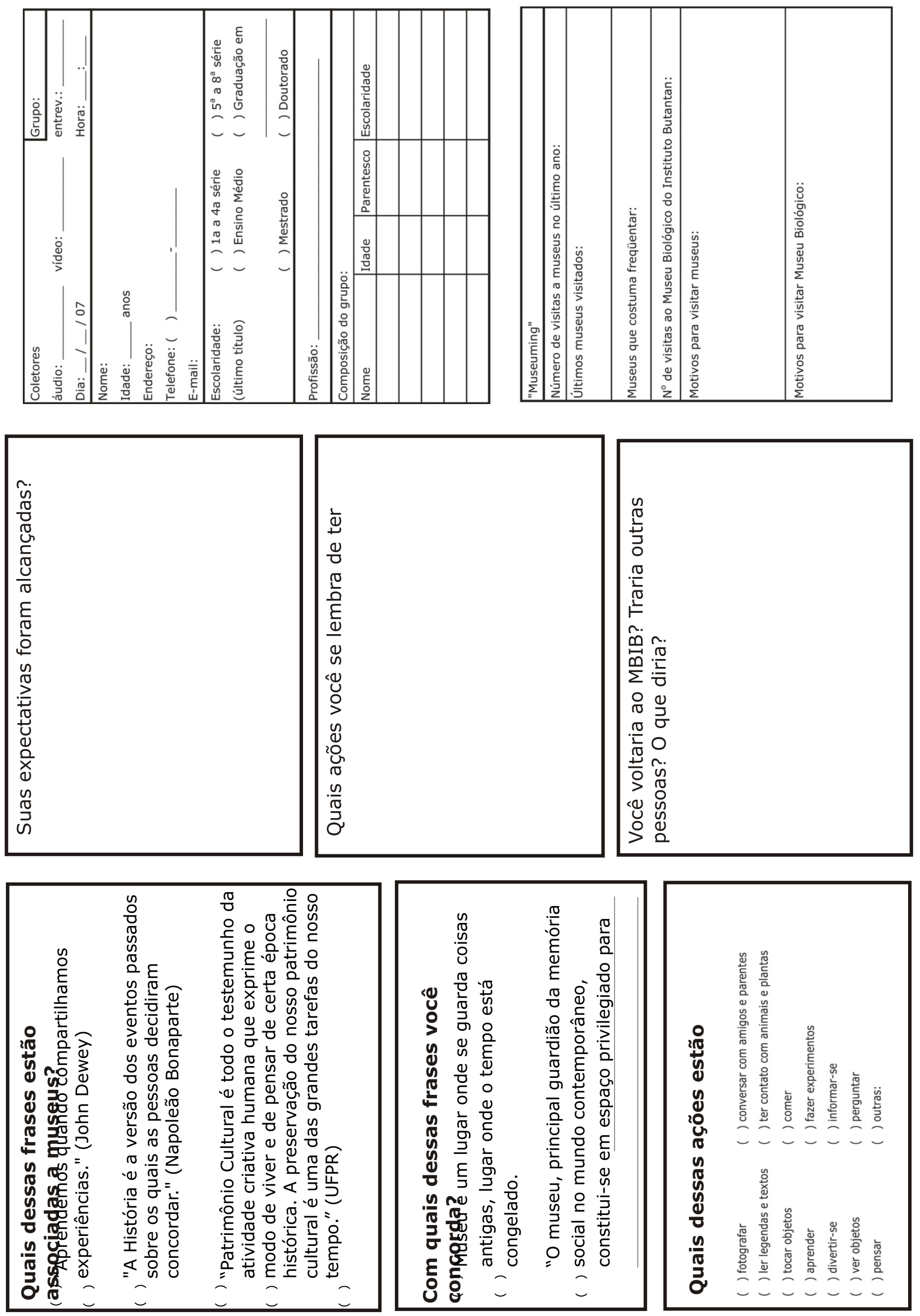

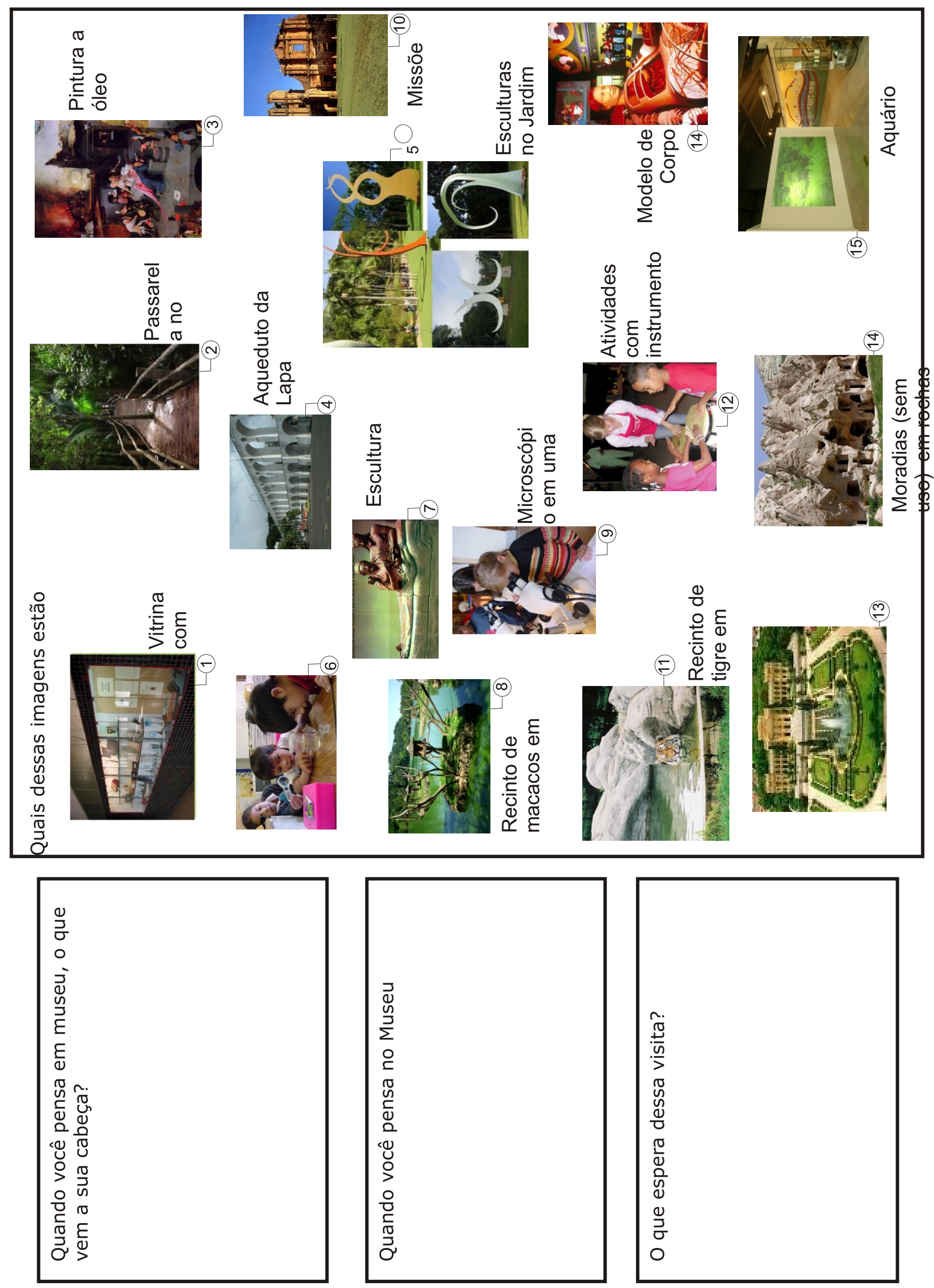
APÊNDICE 3 - EQUIPAMENTOS UTILIZADOS PARA A COLETA DE DADOS JUNTO ÀS FAMÍLIAS.

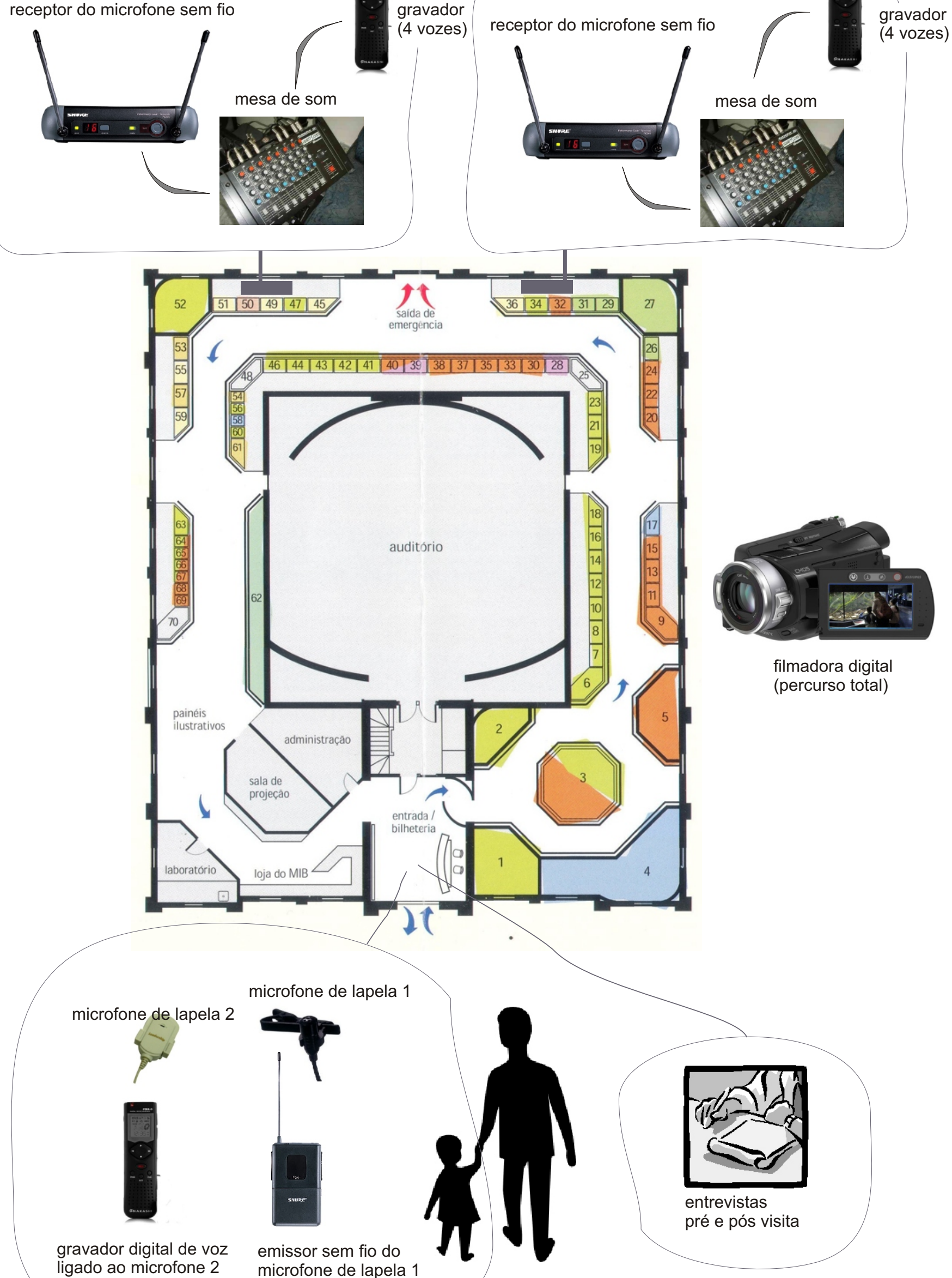



Anexos 



\section{ANEXO 1 - LISTA DE INVESTIGAÇÕES CIENTÍFICAS SOBRE APRENDIZAGEM EM MUSEUS ANALISADAS NESTA INVESTIGAÇÃO}

ADAMS, M.; LUKE, J.; MOUSSOURI, T. Interactivity: moving beyond terminology. Curator, Lanham, vol. 47, n. 2, p. 155-170, apr. 2004.

ALLARD, M.; BOUCHER, S. Éduquer au musée. Un modèle théorique de pédagogie muséale. Montréal: Éditions Hurtubise HMH Ltée, 1998. 207 p.

ALLARD, M.; BOUCHER, S.; FOREST, L. The Museum and the School. McGill Journal of Education, Montreal, vol. 29, n. 2, p. 197-211, spring. 1994.

ALLARD, M.; LAROUCHE, M.C.; LEFEBVRE, B.; MAUNIER, A.; VADEBONCOER, G. La Visite au Musée. Réseau, vol. 27. n. 4, p. 14-19, dec. 1995/jan 1996. Disponível em $<$ http://www.unites.uqam.ca/grem/pdf/la-visite-au-musee.pdf>. Acesso em 24 mar. 2006.

ALLEN, S. Sociocultural theory in museums: insights and suggestions. Journal of Museum Education, Washington, vol. 22, n. 2/3, p. 8-9. 1997a.

ALLEN, S. Using scientific inquiry activities in exhibit explanations. Science Education, New York, vol. 81, n. 6, p. 715-720, nov.1997b.

ALLEN, S. Looking for Learning in Visitor Talk: A Methodological Exploration. In: LEINHARDT, G.; CROWLEY, K.; KNUTSON, K. (eds.). Learning Conversations in Museums. Mahwah: Lawrence Erlbaum, 2002. p. 259-303.

ALLEN, S. Designs for Learning: Studying Science Museum Exhibits That Do More Than Entertain. Science Education, New York, vol. 88, n. S1, p. S17-S33, jul. 2004.

ALLEN, S.; GUTWILL, J. Designing With Multiples Interactivities: Five Common Pitfalls. Curator, Lanham, vol. 47, n. 2, p. 199-212, apr. 2004.

ALMEIDA, A. Evaluation of the Butantan Institute Museum: Limits of the Quantitative Approach. In: DUFRESNE-TASSÉ, C. (ed.). Évaluation et éducation museále: nouvelles tendaces. Montreal: CECA/ICOM, 1998. 192 p.

ALMEIDA, A. Os visitantes do Museu Paulista: um estudo comparativo com os visitantes da Pinacoteca do Estado e do Museu de Zoologia. Anais do Museu Paulista, São Paulo, vol. 12, p. 269-306, jan/dec. 2004. 
ANDERSON, D.; LUCAS, K.; GINNS, I. Theoretical perspectives on learning in an informal setting. Journal of Research in Science Teaching, Reston, vol. 40, n. 2, p. 177-199, feb. 2003.

ASENSIO, M.; POL, E. Cuando la mente va al museo: un enfoque cognitivo-receptivo de los estudos de público. In: IX Jornadas Estatales DEAC-Museos: La Exposición. Jaén: Editorial Diputación de Jaén. 83-134.

ASH, D. Negotiations of Thematic Conversations About Biology. In: LEINHARDT, G.; CROWLEY, K.; KNUTSON, K. (eds.). Learning Conversations in Museums. Mahwah: Lawrence Erlbaum, 2002. p. 357-400.

ASH, D. 2003. Dialogic inquiry in life science conversations of family groups in a museum. Journal of Research in Science Teaching, Reston, vol. 40, n. 2, p. 138-162, feb. 2003.

ASH, D. Reflective scientific sense-making dialogue in two languages: The science in the dialogue and the dialogue in the science. Science Education, New York, vol. 88, n. 6, p. 855884, nov. 2004.

ASH, D.; ELLENBOGEN, K.; CALLANAN, M.; GALCO, J.; CROWLEY, K.; ROGOFF, B. Learning Conversations for all: Explanation, reflective reasoning, thematic content and significant events. AERA Symposium - Exploratorium Museum. 2002. Disponível em $<\mathrm{http}$ //www.exploratorium.edu/cils/presentations-2002/aera_sym_2002_(CILS_folks).doc>. Acesso em 25 jun. 2006.

ASH, D.; LEVITT, K. Working in the zone of proximal development: formative assessment as professional development. Journal of Science Teacher Education, Pittsburgh, vol. 14, n. 1, p. 23-48, feb. 2003.

BLUD, L. Social interaction and learning among family groups visiting a museum. Museum Management and Curatorship, vol. 9, n. 1, p. 43-51, mar. 1990.

BOISVERT, D.; SLEZ, B. The Relationship between Visitor Characteristics and LearningAssociated Behaviors in a Science Museum Discovery Space. Science Education, New York, vol. 78, n. 2, p. 137-148, apr. 1994.

The Relationship between Exhibit Characteristics and Learning-Associated Behaviors in a Science Museum Discovery Space. Science Education, New York, vol. 79, n. 5, p. 503-518, set. 1995. 
BORUN, M. Object-Based Learning and Family Groups. In: PARIS, S. (Ed.). Perspectives on object-centered learning in museums. London: Lawrence Erlbaum Associates, 2002. p. 245-260.

BORUN, M.; CHAMBERS, M.; CLEGHORN, A. Families are learning in science museums. Curator, Lanham, vol. 39, n. 2, p. 124 - 138, jun. 1996.

BRADBURNE, J. Changing designership: The role of the designer in the informal learning environment. Museum Management and Curatorship, vol. 18, n. 2, p. 159-171, jun. 1999.

BRODY, M.; TOMKIEWICZ, W.; GRAVES, J. Park visitors' understandings, values and beliefs related to their experience at Midway Geyser Basin, Yellowstone National Park, USA. International Journal of Science Education, vol. 24, n. 11, p. 1119-1141. 2002.

BROOKE, H.; SOLOMON, J. From playing to investigating: research in an Interactive Science Centre for primary pupils. International Journal of Science Education, vol. 20, n. 8, p. 959-971. 1998.

Passive visitors or independent explorers: Responses of pupils with severe learning difficulties at an Interactive Science Centre. International Journal of Science Education, vol. 23, n. 9, p. 941-953. 2001.

BROWN, C. Making the most of family visits: some observations of parents with children in a museum science centre. Museum Management and Curatorship, vol. 14, n. 1, p. 65-71, mar. 1995.

CAILlOT, M. La Didactique des Sciences: entre Aprentissage Formel et Aprentissage Informel. IV ${ }^{\mathrm{e}}$ Colloque National de L'AIPELF/AFIRSE, Lisbonne, nov. 1993.

CARLISLE, R. What do School Children do at a Science Center? Curator, Lanham, vol. 28, n. 1, p. 27-33, mar. 1985.

CASALEIRO, P. Museum Visitor and Media Science: The Case of the Natural History Museum in Lisbon, Portugal. Museological Review , Leicester, vol. 1, n. 2, p. 33-45. 1995.

COX-PETERSEN, A.; MARSH, D.; KISIEL, J.; MELBER, L. Investigation of guided school tours, student learning, and science reform recommendations at a museum of natural history. Journal of Research in Science Teaching, Reston, vol. 40, n. 2, p. 200-218, feb. 2003. 
CRANE, V. An Introduction to Informal Science Learning and Research. In: CRANE, V.; NICHOLSON, H.; CHEN, M.; BITGOOD, S. (eds.). Informal Science Learning: What the research says about television, science museums and community-based projects. Dedham: Teachers College Press, 1994. p. 1-14.

CROWLEY, K; CALLANAN, M. Describing and Supporting Collaborative Scientific Thinking in Parent-Child Interactions. Journal of Museum Education, Washington, vol. 23, n. 1, p. 12-17. 1998.

CROWLEY, K; CALlANAN, M.; JIPSON, J.; GALCO, J.; TOPPING, K.; SHRAGER, J. Shared Scientific Thinking in Everyday Parent-Child Activity. Science Education, New York, vol. 85, n. 6, p. 712-32, nov. 2001a.

CROWLEY, K.; CALLANAN, M.; TENENBAUM, H.; ALLEN, E. Parents explain more often to boys than to girls during shared scientific thinking. Psychological Science, Washington, vol. 12, n. 3, p. 258-261, may . 2001b.

CROWLEY, K.; JACOBS, M. Building Islands of Expertise in Everyday Family Activity. In: LEINHARDT, G.; CROWLEY, K.; KNUTSON, K. (eds.). Learning Conversations in Museums. Mahwah: Lawrence Erlbaum, 2002. p. 333-356.

CSIKSZENTMIHALYI, M., \& HERMANSON, K. Intrinsic motivation in museums: What makes visitors want to learn? Museum News, vol. 74, n. 3, p. 34-37, May/June 1995.

CUESTA, M.; DÍAZ, P.; ECHEVARRIA, I.; MORENTIN, M.; ABAD, C. Los museos y centros de ciência como ambientes de aprendizaje. Alambique - Didáctica de las Ciencias Experimentales, vol. 26, p. 21-28, oct-dic. 2000.

DAVAllON, J.; GOTTESDIENER, H.; POLI, M. The "expert visitor" concept. Museum International, Paris, vol. 52, n. 4, p. 60-64, oct. 2000.

DIERKING, L.; FALK, J. Family Behavior and Learning in Informal Science Settings: a Review of the Research. Science Education, New York, vol. 78, n. 1, p. 52-72, jan. 1994.

DIERKING, L. The Role of Context in Children's Learning from Objects and Experiences. In: PARIS, S. (Ed.). Perspectives on object-centered learning in museums. London: Lawrence Erlbaum Associates, 2002. p. 3-18. 
DIERKING, L.; ELLENBOGEN, K.; FALK, J. In Principle, In Practice: Perspectives on a Decade of Museum Learning Research (1994-2004). Science Education, New York, vol. 88(Suppl. 1), editorial. 2004.

DUFRESNE-TASSÉ, C. Comparason du Rôle de l'Évaluation à l'École et au Musée; Implications pour la Pratique Muséale. In: LEFEBVRE, B.; ALLARD, M.. (eds.). Le Musée, un Lieu Educatif. Montreal: Musée d'art contemporain, 1997. 416 p.

DUFRESNE-TASSÉ, C. Problems of an Educational Intervention Based on the Adult Visitor's Behaviour. In: RAUTELA, G. (ed.), Museums for Integration in a Multicultural Society. New Delhi: ICOM-Asia, 1994.

DURBIN, G.; MORRIS, S.; WILKINSON, S. Learning from Objects: a Teacher's Guide. Southampton: English Heritage, 1990. 36 p.

ELLENBOGEN, K. M.; LUKE, J. J.; DIERKING, L. D. Family Learning Research in Museums: An emerging Disciplinary Matrix? Science Education, New York, vol. 88, n. S1, p. S48-S58, July 2004.

FALCÃO, D. Padrões de interação e aprendizagem em museus de ciências. 1999. 0 f. Dissertação (Mestrado em Bioquímica) - Universidade Federal do Rio de Janeiro, 1999.

FALCÃO, D.; ALVES, F.; KRAPAS, S.; COLINVAUX, D. Museus de Ciências, Aprendizagem e Modelos Mentais: Identificando Relações. In: GOUVÊA, G.; MARANDINO, M.; LEAL, M. (orgs.). Educação e Museus: A Construção Social do Caráter Educativo dos Museus de Ciências. Rio de Janeiro: FAPERJ/Access Editora. 2003. p.185-206.

FALK, J. Visitors - Who does, Who doesn't, and Why. Museum News, vol. 77, n. 2, p. 3843, mar/apr . 1998.

Free-Choice Science Learning: Framing the Discussion. In: FALK, J. (ed.). FreeChoice Science Education: How We Learn Science Outside of School. Teachers College, Columbia University. 2001. p. 3-20.

Foreword. In: PARIS, S. (Ed.). Perspectives on object-centered learning in museums. London: Lawrence Erlbaum Associates, 2002. p. ix-xiii.

The Director's Cut: Toward an Improved Understanding of Learning from Museums. Science Education, New York, vol. 88, n. S1, p. S83-S96, jul. 2004. 
FALK, J.; ADELMAN, L. Investigating the impact of prior knowledge and interest on aquarium visitor learning. Journal of Research in Science Teaching, Reston, vol. 40, n. 2, p. 163-176, Feb. 2003.

FALK, J.; DIERKING, L. The Museum Experience. Washington: Whalesback Books. 1992. $206 \mathrm{p}$.

School Field Trips: Assessing Long-Term Impact. Curator, Lanham, vol. 40, n. 3, p. 211-218, sep. 1997.

Learning from Museums: Visitors Experiences and the Making of Meaning. Walnut Creek: Altamira Press. 2000. 272 p.

FALK, J.; MOUSSOURI, T.; COULSON, D. The Effect of Visitors' Agendas on Museum Learning. Curator, Lanham, vol. 41, n. 2, p. 106-120, jun. 1998.

FALK, J.; STORKSDIECK, M.. Learning science from museums. História, Ciências e Saúde, Rio de Janeiro, vol.12(supl.), p. 117-143. 2005a

Using the contextual model of learning to understand visitor learning from a science center exhibition. Science Education, New York, vol. 89, n. 5, p. 744-778, sep. 2005b.

FALK, J.; SCOTT, C.; DIERKING, L.; RENNIE, L.; JONES, M. Interactives and Visitor Learning. Curator, Lanham, vol. 47, n. 2, p. 171-198, apr. 2004.

FERNÁNDEZ, G.; BENLLOCH, M. Interactive exhibits: how visitors respond. Museum International, Paris, vol. 52, n. 4, p. 53-59, oct. 2000.

FORS, V. Science centre exhibits - from a teenager's point of view. 12p. 2004. Disponível em: < http://www.ltu.se/polopoly_fs/1.2943!51efbdce.pdf>. Acesso em: 04 mai. 2008.

GAMMON, B. Assessing learning in museum environments: A practical guide for museum evaluators. London, Science Museum, unpublished report. 2001. Disponível em: $<\mathrm{http}$ ///www.ecsite-uk.net/events/reports/indicators_learning_1103_gammon.pdf $>$. Acesso em: 04 mai. 2008.

GARCIA, V. R. O Processo de ensino-aprendizagem no Zôo de Sorocaba: análise da atividade de educativa visita orientada a partir dos objetos biológicos. 2006. 224 fls. Dissertação (Mestrado em Educação) - Faculdade de Educação, Universidade de São Paulo, 2006. 
GASPAR, A. Museus e Centros de Ciências - conceituação e proposta de um referencial teórico. 1993. 173 fls. Tese (Doutorado em Educação) - Faculdade de Educação, Universidade de São Paulo, 1993.

GASPAR, A.; HAMBURGER, E. Museus e Centros de Ciências. In: NARDI, R. (org.) Pesquisas em Ensino de Física. São Paulo: Escrituras Editora, 1998. p. 105-125.

GERBER, B.; MAREK, E.; CAVALLO, A. Development of an learning opportunities assay. International Journal of Science Education, vol. 23, n. 6, p.569-583. 2001.

GILBERT, J. Learning in Museums: objects, models and text. Journal for Education in Museums, Gillingham, vol. 16, p. 19-21.1995.

GILBERT, J.; PRIEST, M. Models and Discourse: A Primary School Science Class Visit to a Museum. Science Education, New York, vol. 81, n. 6, p. 749-762, nov. 1997.

GILBERT, J. \& STOCKLMAYER, S. The Design of Interactive Exhibits to Promote the Making of Meaning. Museum Management and Curatorship, vol. 19, n. 1, p. 41-50, mar. 2001.

GRIFFIN, J. Learning to learn in informal settings. Research in Science Education, vol. 24, n. 1, p. 121-128, dec. 1994.

Learning science through practical experiences in museums. International Journal of Science Education, vol. 20, n. 6, p. 655-663. 1998.

Research on Students and Museums: Looking More Closely at the Students in School Groups. Science Education, New York, vol. 88, n. S1, p. S59-S70, jul. 2004.

GUNTHER, C. Museum-goers: life-styles and learning characteristics. In: HOOPERGREENHILL, E. (ed.) The Educational Role of the Museum. Londres: Routledge. 1994b. p. 118-130.

HALL, R.; SCHAVERIEN, L. Families' engagement with young children's science and technology learning at home. Science Education, New York, vol. 85, n. 4, p. 454-481, jul. 2001. 
HEARD, P., DIVALL, S. \& JOHNSON, S. Can 'ears-on' help hands-on science learning for girls and boys? International Journal of Science Education, vol. 22, n. 11, p. 11331146. 2000.

HEIN, G. Learning in the Museum. London: Routledge. 1998. 203 p.

John Dewey and Museum Education. Curator, Lanham, vol. 47, n. 4, p. 413-427, oct. 2004.

HENRIKSEN, E. Environmental Issues in the Museum: Applying Public Perceptions in Exhibition Development. Curator, Lanham, vol. 41, n. 2, p. 90-106, jun. 1998.

HENRIKSEN, E.; JORDE, D. High School Students'Understanding of Radiation and the Environment: Can Museums Play a Role? Science Education, New York, vol. 85, n. 2, p. 189-206, mar. 2001.

HOFSTEIN, A.; ROSENFELD, S. Bridging the Gap Between Formal and Informal Science Learning. Studies in Science Education, vol. 28, n. 1, p. 87-112. 1996.

HOOPER-GREENHILL, E. The 'art of memory' and learning in the museum: The challenge of GCSE. Museum Management and Curatorship, vol. 7, n. 2, p. 129-137, jun. 1988.

Education, communication and interpretation: towards a critical pedagogy in museums. In: HOOPER-GREENHILL, E. (ed.) The Educational Role of the Museum. Londres: Routledge. 1994a. p. 3-27.

Communication in theory and practice. In: HOOPER-GREENHILL, E. (ed.) The Educational Role of the Museum. Londres: Routledge. 1994b. p. 28-43.

Museum learners as active post-modernists: contextualizing constructivism. In: HOOPER-GREENHILL, E. (ed.) The Educational Role of the Museum. Londres: Routledge. 1994c. p. 67-72.

HUGHES, P. Making Science 'Family Fun': The Fetish of the Interactive Exhibit. Museum Management and Curatorship, vol. 19, n. 2, p. 175-185, jun. 2001.

JARRETT, J. Learning from Developmental Testing of Exhibits. Curator, Lanham, vol. 29, n. 4, p. 295-306, dec. 1986. 
JEFFERY-CLAY, K. Constructivism in Museums: How Museums Create Meaningful Learning Environments. Journal of Museum Education, Washington, vol. 23, n. 1, p. 3-7. 1998.

JOHNSTON, D.; RENNIE, L. Education: Perceptions of visitors' learning at an interactive science and technology centre in Australia. Museum Management and Curatorship, vol. 14, n. 3, p. 317-324, sep. 1995.

KELLY, L. Understanding Museum Learning from the Visitor's Perspective. Curator, Lanham, vol. 46, n. 4, p. 362-366, oct. 2003.

KISIEL, J. Understanding elementary teacher motivations for science fieldtrips. Science Education, New York, vol. 89, n. 6, p. 936-955, nov. 2005.

KÖPTKE, L. Parceria Museu e Escola como experiência social e espaço de afirmação do sujeito. In: GOUVÊA, G.; MARANDINO, M., LEAL, M. (orgs.). Educação e Museu. A construção social do caráter educativo dos museus de ciências. Rio de Janeiro: Acces, 2003, p. $107-128$.

KORN, R. An Analysis of Differences Between Visitors at Natural History Museums and Science Centers. Curator, Lanham, vol. 38, n. 3, p. 150-160, sep. 1995.

LEINHARDT, G.; CROWLEY, K. Objects of Learning, Objects of Talk: Changing Minds in Museums. In: PARIS, S. (Ed.). Perspectives on object-centered learning in museums. London: Lawrence Erlbaum Associates, 2002. p. 301-324.

LEINHARDT, G.; KNUSTON, K.; CROWLEY, K. Museum Learning Collaborative Redux. Journal of Museum Education, Washington, vol. 28, n. 1, p. 23-31. 2003.

LIMA, E. Desenvolvimento e Aprendizagem na Escola: Aspectos Culturais, Neurológicos e Psicológicos. São Paulo: Série "Separatas" - Grupo de Estudos do Desenvolvimento Humano (GEDH). 1997.

LINDEMANN-MATTHIES, P.; KAMER, T. The influence of an interactive educational approach on visitors' learning in a Swiss zoo. Science Education, New York, vol. 89, n. 1, p. 1-20, jan. 2005.

MACLULICH, C. Learning about learning. In: DUFRESNE-TASSÉ, C. (ed.). Diversité culturelle, distance et aprentissage. Montreal: CECA/ICOM, 2000. 
MARANDINO, M. O Conhecimento Biológico nas Exposições de Museus de Ciências: análise do processo de construção do discurso expositivo. 201, 434 fls. Tese (Doutorado em Educação) - Faculdade de Educação, Universidade de São Paulo. 2001.

MARANDINO, M.; BIZERRA, A.; NAVAS, A. M.; FARES, D.; STANDERSKI, L.; MONACO, L.; MARTINS, L.; SOUZA, M. P.; GARCIA, V. Educação em museus: a mediação em foco. São Paulo: GEENF/FEUSP. 2008. p. 36.

MAROEVIC, I. The Museum Exhibition as Presentation and Representation of Knowledge. Museological Review, Leicester, vol. 5, n. , p. 1-13. 1998.

MARQUES, D. Arqueologia e educação: uma proposta de leitura do patrimônio. 2005, 152 fls. Dissertação (Mestrado em Arqueologia) - Museu de Arqueologia e Etnologia, Universidade de São Paulo. 2005.

MARTIN, L. An Emerging Research Framework for Studying Informal Learning and Schools. Science Education, New York, vol. 88, n. S1, p. S71-S82, jul. 2004.

MARTINS, J. Ambientes de aprendizagem e Experimentoteca-Ludoteca. 1996.121 fls. Dissertação (Mestrado em Ensino de Ciências) - Universidade de São Paulo. 1996.

MICHENER, D.; SCHULTZ, I. Through the Garden Gate: Objects and Informal Education for Environmental and Cultural Awareness in Arboreta and Botanic Gardens. In: PARIS, S. (Ed.). Perspectives on object-centered learning in museums. London: Lawrence Erlbaum Associates, 2002. p.95-112.

MCMANUS, P. Good companions: More on the social determination of learning-related behaviour in a science museum. Museum Management and Curatorship, vol. 7, n. 1, p. 3744, jan. 1988.

MCMANUS, P. Topics in Museums and Science Education. Studies in Science Education, vol. 20, n. 1, p. 157-182. 1992.

OSBERG, S. Shared Lessons and Self-Discoveries: What Research Has Taught Children's Discovery Museum. Journal of Museum Education, Washington, vol. 23, n. 1, p. 19-20. 1998.

OSBORNE, J. Constructivism in Museums: A Response. Journal of Museum Education, Washington, vol. 23, n. 1, p. 8-9. 1998. 
PARIS, S.; ASH, D. Reciprocal Theory Building Inside and Outside Museums. Curator, Lanham, vol. 43, n. 3, p. 199-210, jul. 2000.

PARIS, S.; HAPGOOD, S. Children Learning with Objects in Informal Learning Environments. In: PARIS, S. (Ed.). Perspectives on object-centered learning in museums. London: Lawrence Erlbaum Associates, 2002. p. 37-54.

PARIS, S.; MERCER, M. Finding Self in Objects: Identity Exploration in Museums. In: LEINHARDT, G.; CROWLEY, K.; KNUTSON, K. (eds.). Learning Conversations in Museums. Mahwah: Lawrence Erlbaum, 2002. p. 401-423.

PEDRETTI, E. Perspectives on learning through research on critical issues-based science center exhibitions. Science Education, New York, vol. 88, n. S1, p. S34-S47, jul. 2004.

PEKARIK, A.; DOERING, Z.; KARNS, D. Exploring Satisfying Experiences in Museums. Curator, Lanham, vol. 42, n. 2, p. 152-173, Apr. 1999.

PUCHNER, L.; RAPOPORT, R.; GASKINS, S. Learning in Children's Museums: Is It Really Happening? Curator, Lanham, vol. 44, n. 3, p. 237-259, jul. 2001.

RAHM, J. Multiple modes of meaning-making in a science center. Science Education, New York, vol. 88, n. 2, p. 223-247, Mar. 2004.

RENNIE, L.; FEHER, E.; DIERKING, L.; FALK, J. Toward an agenda for advancing research on science learning in out-of-school settings. Journal of Research in Science Teaching, Reston, vol. 40, n. 2, p. 112-120, Feb. 2003.

RENNIE, L. J.; JOHNSTON, D. J. The Nature of Learning and Its Implications for Research on Learning from Museums. Science Education, New York, v. 88, n. S1, p. S4-S16, jul. 2004.

RENNIE, L.; MCCLAFFERTY, T. 2002. Objects and Learning: Understanding Young Children's Interaction with Science Exhibits. In: PARIS, S. (Ed.). Perspectives on objectcentered learning in museums. London: Lawrence Erlbaum Associates, 2002. p. 191-214.

RICE, D. Constructing Informed Practice. Journal of Museum Education, Washington, vol. 23, n. 1, p. 10-11. 1998.

RIX, C.; MCSORLEY, J. An investigation into role that school-based interactive science centres may play in the education of primary-aged children. International Journal of Science Education, vol. 21, n. 6, p. 577-593. 1999. 
ROBERTS, L. Educators on Exhibit Teams: a New Role, a New Era. Journal of Museum Education, Washington, vol. 19, n. 3, p. 6-9. 1994.

ROUNDS, J. Why Are Some Science Museum Exhibits More Interesting Than Others? Curator, Lanham, vol. 43, n. 3, p. 188-198, jul. 2000.

ROWE, S. The role of objects in active, distributed meaning-making. In: PARIS, S. (Ed.). Perspectives on object-centered learning in museums. London: Lawrence Erlbaum Associates, 2002. p.19-35.

SAPIRAS, A. Aprendizagem em Museus: uma análise das visitas escolares no Museu Biológico do Instituto Butantan. 2007. 155 fls. Dissertação (Mestrado em Educação) Faculdade de Educação, Universidade de São Paulo. 2007.

SCHÄRER, M. La Relation Homme-Objet Exposée: Théorie et Pratique d'une Expérience Muséologique. Publics \& Musées, Lyon, vol. 15, n. , p. 31-43. 1999.

SCHAUBLE, L.; GLEASON, M.; LEHRER, R. ; BARTLETT, K. ; PETROSINO, A. ; ALLEN, A.; CLINTON, K. ; HO, E. ; JONES, M. ; YEE, Y.-S. ; PHILLIPS, J.-E. ; SIEGLER, J. ; STREET, J. Supporting science learning in museums. In LEINHARDT, G.; CROWLEY, K.; KNUTSON, K. (eds.). Learning conversations in museums. Mahwah: Lawrence Erlbaum, 2002. p. 425-452.

; LEINHARDT, G.; MARTIN, L. A framework for organizing a cumulative research agenda in informal learning contexts. Journal of Museum Education, Washington, vol. 22, n. 2/3, p. 3-8. 1997. Disponível em: <http://www.museumlearning.org/mlc_jme.pdf>. Acesso em: 07. mai. 2008.

SCREVEN, C. Museums and Informal Education. Disponível em: <http://www.museumstudies.si.edu/bull/may93/screven.htm>. Acesso em 15 ago. 2004.

SERRELL, B. Paying Attention: The Duration and Allocation of Visitors' Time in Museum Exhibitions. Curator, Lanham, vol. 40, n. 2, p. 108-125, jun. 1997.

SHAVELSON Shavelson, R.; Phillips, D.; Towne, L.; Feuer, M. On the Science of Education Design Studies. Educational Researcher, Washington, vol. 32, n. 1, p. 25-28, jan/fev. 2003.

SILVERMAN, L. Visitor meaning-making in museums for a new age. Curator, Lanham, vol. 38, n. 3, p. 161-170, sep. 1995. 
SMITH, M. 2001. Non-formal education. Disponível em: <http://www.infed.org/biblio/bnonfor.htm\#idea>. Acesso em 15 ago. 2004.

SOREN, B. Triangulation strategies and images of museums as sites for lifelong learning. Museum Management and Curatorship, vol. 14, n. 1, p. 31-46, mar. 1995.

SPOCK, D. Is It Interactive Yet? Curator, Lanham, vol. 47, n. 4, p. 369-374, oct. 2004.

STOCKLMAYER, S.; GILBERT, J. New experiences and old knowledge: towards a model for the personal awareness of science and technology. International Journal of Science Education, vol. 24, n. 8, p. 835-858. 2002.

STUDART, D. Museus e famílias: percepções e comportamentos de crianças e seus familiares em exposições para o público infantil. História, Ciências e Saúde, Rio de Janeiro, vol. 12(supl.), p. 55-77. 2005.

TAL, R.; BAMBERGER, Y.; MORAG, O. Guided school visits to natural history museums in Israel: Teachers' roles. Science Education, New York, vol. 89, n. 6, p. 920-935, nov. 2005.

TIRADO, F.; BUSTOS, A. Desarrollo de Estructuras Cognoscitivas Para el Aprendizaje de la Historia, a partir de un Programa Computadorizado y la Visita a Museos. In: DUFRESNETASSÉ, C. (ed.). Évaluation et éducation museále: nouvelles tendaces. Montreal: CECA/ICOM, 1998. 192 p.

TRAN, L. Teaching Science in Museums: The Pedagogy and Goals of Museum Educators. Science Education, New York, vol. 91, n. 2, p. 278-297, Mar. 2007.

TULLEY, A.; LUCAS, A. Interacting with a science museum exhibit: vicarious and direct experience and subsequent understanding. . International Journal of Science Education, vol. 13, n. 5, p. 533-542. 1991.

TUNNICLIFFE, S. Conversations of family and primary school groups at robotic dinosaur exhibits in a museum: what do they talk about. International Journal of Science Education, vol. 22, n. 7, p. 739-754. 2000.

; LUCAS, A.; OSBORNE, J. School visits to zoos and museums: a missed educational opportunity? International Journal of Science Education, vol. 19, n. 9, p. 1039-1056. 1997. 
VAN-PRAËT, M. Aspects of Learning in the Natural History Museum. Or, are all Visitors Disabled in Science? Art Bulletin of Nationalmuseum Stockholm, Estocolmo, vol. 5, p. 131-136. 1998.

VAN-PRAËT, M; POUCET, B Les Musées, Lieux de Contre-Éducation et de Partenariat avec l'École. Éducation \& Pédagogies, vol. 16, p. 21-29. 1992. Disponível em: $<$ http://www.ac-grenoble.fr/patrimoine-education/seminaire/contreduc_partena.htm>. Acesso em 12 mar. 2006.

XANTHOUDAKI, M. Educational provision for young people as independent visitors to art museums and galleries: issues of learning and training. Museum Management and Curatorship, vol. 17, n. 2, p. 159-172, jun. 1998.

ZOLCSAK, E.; VITIELLO, N.; FEDERSONI J, P.A. ; BUONONATO, M.A. . Análise do aprendizado do visitante do Museu do Instituto Butantan. Ciência e Cultura, São Paulo, vol. 40, n. 2, p. 190-193. 1988. 